\title{
Copper-Catalyzed Oxyalkynylation of C-S Bonds in Thiiranes and Thiethanes with Hypervalent lodine Reagents
}

\author{
Julien Borrel, ${ }^{\dagger}$ Guillaume Pisella, ${ }^{\dagger}$ and Jerome Waser*๑ \\ Laboratory of Catalysis and Organic Synthesis, Institute of Chemical Sciences and Engineering, Ecole Polytechnique Fédérale de \\ Lausanne, EPFL SB ISIC LCSO, BCH 1402, 1015 Lausanne, Switzerland
}

\section{Supporting Information}

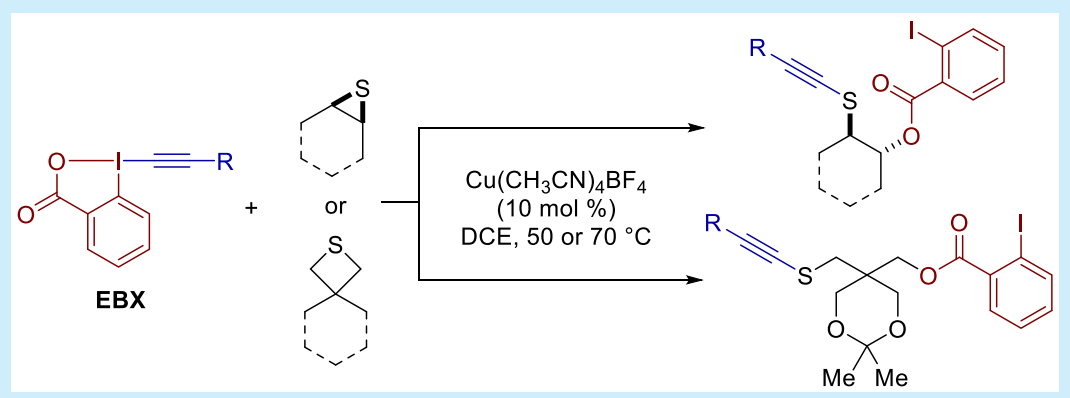

ABSTRACT: We report the oxyalkynylation of thiiranes and thietanes using ethynylbenziodoxolone reagents (EBXs) to readily access functionalized building blocks bearing an alkynyl, a benzoate, and an iodide group. The reaction proceeds with high atom efficiency most likely through an alkynyl-episulfonium intermediate. The transformation is copper-catalyzed and compatible with a large array of thiiranes and thietanes.

S train-promoted ring opening of small saturated heterocycles (three- and four-membered rings) is an attractive way to access 1,2- or 1,3-functionalized building blocks. This approach has been thoroughly investigated for oxygen and nitrogen heterocycles including epoxides, ${ }^{1}$ aziridines, ${ }^{2}$ and oxetanes. ${ }^{3}$ In comparison, this strategy has been less explored for the sulfur analogues, thiiranes ${ }^{1,4}$ and thietanes, ${ }^{5}$ despite the importance of sulfur-containing molecules. ${ }^{6}$ The more reactive thiiranium ion is a well-described intermediate and has been recently involved in the development of highly enantioselective transformations. ${ }^{7}$ Its formation often relies on the reaction of alkenes with an electrophilic sulfur source or the nucleophilic substitution of a leaving group next to a thioether (Scheme 1a). Their generation by reaction of an electrophile with the sulfur atom is unusual. ${ }^{7 \mathrm{a}, \mathrm{b}}$ A few recent reports explored this method of activation either by alkylation for a subsequent ring expansion ${ }^{8}$ or by arylation to induce a ring opening.

In contrast, the generation of a noncyclic sulfonium ion by alkylation of thioethers is a well-known method. ${ }^{7 \mathrm{~b}, 10}$ To the best of our knowledge, only one report published by Ochiai and coworkers presented their formation by alkynylation (Scheme 1b). ${ }^{11}$ Ethynyliodonium salts were used to synthesize alkynyl(diphenyl)sulfonium salts. When thioanisole (1) was alkynylated with iodonium $\mathbf{2}$, sulfonium intermediate $\mathbf{A}$ reacted with an excess of 1 to give thioalkyne 4. Later, a mild and selective protocol for the formation of thioalkynes was proposed by our group using thiols and ethynylbenziodoxolones (EBX). ${ }^{12}$ Iodonium salts were not suitable for this transformation, as they led to the formation of disulfides. Considering the high sulfur affinity of hypervalent iodine reagents, we anticipated that they could be used for the generation of an alkynylated episulfonium intermediate from the corresponding thiirane (Scheme 1c).

EBX reagents were expected to be superior in this reaction, as their activation using metal catalysis is well-established ${ }^{13}$ and the released benzoate $\mathbf{5}$ can act directly as a nucleophile for the formed episulfonium, resulting in a highly atom-economical process. ${ }^{14}$ The obtained $\beta$-hydroxy sulfide motif is found in a large array of bioactive molecules ${ }^{15}$ and is mostly accessed by epoxide ring opening. The reverse approach exploiting thiirane chemistry has been less developed, ${ }^{16}$ except for the acetolysis of carbohydrate bearing a thiirane at the $\mathrm{C}_{5}-\mathrm{C}_{6}$ position. ${ }^{17}$

Herein, we report the successful copper-catalyzed oxyalkynylation of thiiranes using EBX reagents. The reaction probably proceeds through the formation of an episulfonium intermediate and furnishes the desired $\beta$-hydroxy sulfides in moderate to good yields using operationally simple conditions. The methodology was also applied to the ring opening of thietanes to access 1,3-difunctionalized products.

We started our investigation by optimizing the reaction conditions using TIPS-EBX (6a) and the commercially available cyclohexene sulfide (7a) as a model substrate (Table 1; see Supporting Information for a full list of tested reaction conditions, Table S1). No product was observed in the absence of catalyst or in the presence of TMSCl as Lewis acid (entries 1 and 2). However, we were pleased to see that addition of a catalytic amount of $\mathrm{Cu}\left(\mathrm{CH}_{3} \mathrm{CN}\right)_{4} \mathrm{BF}_{4}$ afforded the desired

Received: November 20, 2019

Published: December 31, 2019 
Scheme 1. Strategies Exploiting Thiiranium and Sulfonium Ions for $\mathrm{C}-\mathrm{S}$ Bond Activation

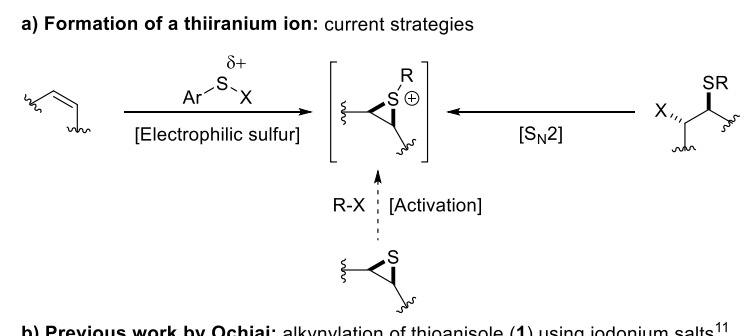

b) Previous work by Ochiai: alkynylation of thioanisole (1) using iodonium salts ${ }^{11}$

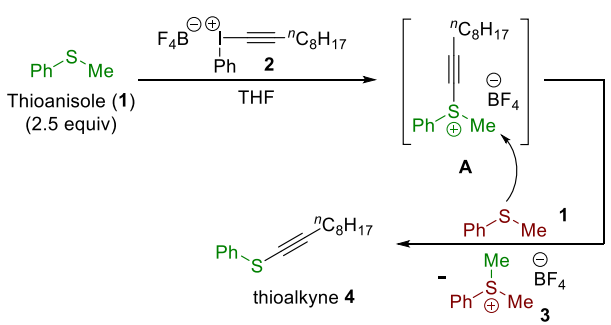

c) This work: Cu-catalyzed oxy-alkynylation of thiiranes with $\mathrm{EBX}$ reagents

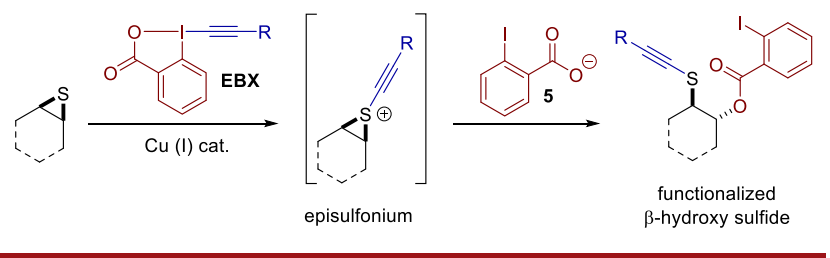

Table 1. Optimization of the Oxyalkynylation ${ }^{a}$

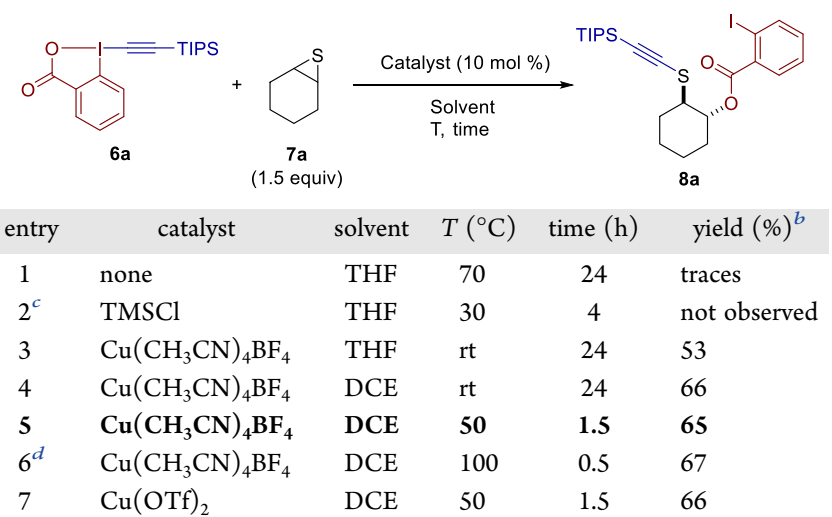

${ }^{a}$ Reaction conditions: TIPS-EBX (6a) $(0.1 \mathrm{mmol})$, cyclohexene sulfide (7a) $(0.15 \mathrm{mmol})$, catalyst $(10 \mathrm{~mol} \%)$, solvent $(0.07 \mathrm{M})$, reactions were carried out under $\mathrm{N}_{2}$ atmosphere. ${ }^{b}$ Isolated yield. ${ }^{c} 1$ equiv of TMSCl was used. ${ }^{d}$ Reaction was performed under microwave irradiation.

product $8 \mathbf{a}$ in $53 \%$ yield as a single diastereoisomer (entry 3 ). The relative trans configuration was confirmed by $\mathrm{X}$-ray crystallography. Different solvents were screened: replacing THF with DCE increased the yield to $66 \%$ (entry 4). Working at higher temperatures resulted in a significant lower reaction time with no influence on the yield (entries 4-6). Next, we examined a range of copper catalysts (see Supporting Information). A similar yield was obtained only when $\mathrm{Cu}(\mathrm{OTf})_{2}$ was used (entry 7). Oligomers containing multiple cyclohexyl sulfide motifs were identified as byproducts of the reaction. To reduce this side reactivity different concentrations, stoichiometries of $6 a / 7 a$ and copper loadings were examined (see Table S2 for details), but the reaction yield was constantly between 45 and $65 \%{ }^{18}$
With the optimized conditions in hand (entry 5), we first investigated a range of structurally diverse thiiranes (Scheme 2). Using cyclopentene sulfide allowed the synthesis of $\mathbf{8 b}$ in a slightly improved yield. Incorporation of an oxygen or a protected nitrogen atom in the ring afforded $\mathbf{8 c}$ and $\mathbf{8 d}$ in good and moderate yield, respectively. Simple ethylene sulfide 6e provided a lower yield of $\mathbf{8 e}(46 \%)$. However, this result has to be put in perspective with the known tendency of $7 \mathbf{e}$ to polymerize, as well as its low boiling point $\left(55^{\circ} \mathrm{C}\right) .{ }^{19}$ When the reaction was performed with unsymmetrical propylene sulfide, $8 \mathbf{f}$ was obtained as a mixture of regioisomers (2.1:1 rr), the major one resulting from the attack of the carboxylate at the most substituted position. A similar outcome was observed with a longer alkyl chain (product $\mathbf{8 g}$ ). Using the disubstituted analogue $7 \mathbf{h}$ led to a significant improvement of the regioselectivity (15.5:1 rr), although with a diminished yield of $\mathbf{8 h}$. When the reaction was run with the enantioenriched substrate $\mathbf{7} \mathbf{i}$, it afforded $\mathbf{8} \mathbf{i}$ with full conservation of the ee for both regioisomers. In this case, we were surprised to observe an inversion of regioselectivity. We hypothesize that it could be due to the inductive effect of the nearby oxygen. The synthesis of $8 \mathbf{j}$ incorporating two protected alcohols was achieved in a lower yield.

Next, we examined different hypervalent iodine reagents. Substitution of the TIPS group by aryl substituents was welltolerated and showed little impact on the reaction $(8 \mathbf{k}-\mathbf{m})$. Alkyl-EBX gave also good results $(\mathbf{8 n}-\mathbf{o})$. A lower yield was observed for $\mathbf{8 p}$, and decreasing the temperature furnished a slightly better result. Modification of the iodobenzoic acid core with a methoxy, a nitro, or a fused benzene ring allowed the synthesis of products $\mathbf{8 q}-\mathbf{s}$ in good yields. Importantly, vinylbenziodoxolone reagents (VBX) could be used successfully in the transformation, providing the oxyvinylated products $8 \mathbf{t}-\mathbf{u}$ in promising yields without further optimization.

We next examined the transformation of the less strained thietane heterocycles (Scheme 3). We were pleased to see that simple thiacyclobutane $(9 \mathrm{a})$ reacted under similar reaction conditions to deliver 1,3-functionalized thioalcohol 10a in moderate yield. Introduction of a phenyl group at the 3-position of the thiacyclobutane did not affect the transformation (product 10b). Spirocyclic substrates 9c and 9d gave improved yields of products $10 \mathrm{c}$ and $10 \mathrm{~d}$ and demonstrated the selectivity of the reaction for sulfur heterocycles. Considering the good results obtained with four-membered rings, the reaction of tetrahydrothiophene (9e) was examined next. At higher temperature $\left(100{ }^{\circ} \mathrm{C}\right)$, we could obtain the 1 ,4-functionalized thioalcohol 10e in moderate yield.

To highlight the synthetic utility of our method, further functionalizations of $\mathbf{8 a}$ were performed (Scheme 4a). We first focused on the reactivity of the iodobenzoate ester: Sonogashira cross-coupling with the iodine afforded 11 in good yield, and the saponification of the iodobenzoic ester allowed the synthesis of the free alcohol 12. Next, we turned our attention toward the thioalkyne function. A sequence of TIPS deprotection followed by copper-catalyzed alkyne-azide cycloaddition afforded triazole 14 in excellent yield. A scale-up reaction $(2 \mathrm{mmol})$ was then carried out using Ph-EBX (6k) and cyclohexene sulfide (7a) (Scheme 4b). The reaction gave a similar yield at this scale. The synthesized phenyl thioalkyne $\mathbf{8 k}$ was hydrated to afford thioester 15 in good yield.

A series of experiments were carried out to gain more insight into the reaction mechanism (Scheme 5). We first attempted the ring opening of cyclohexene sulfide $(7 \mathbf{a})$ in the presence of a 
Scheme 2. Scope of the Oxyakynylation with Thiiranes and HIRs*

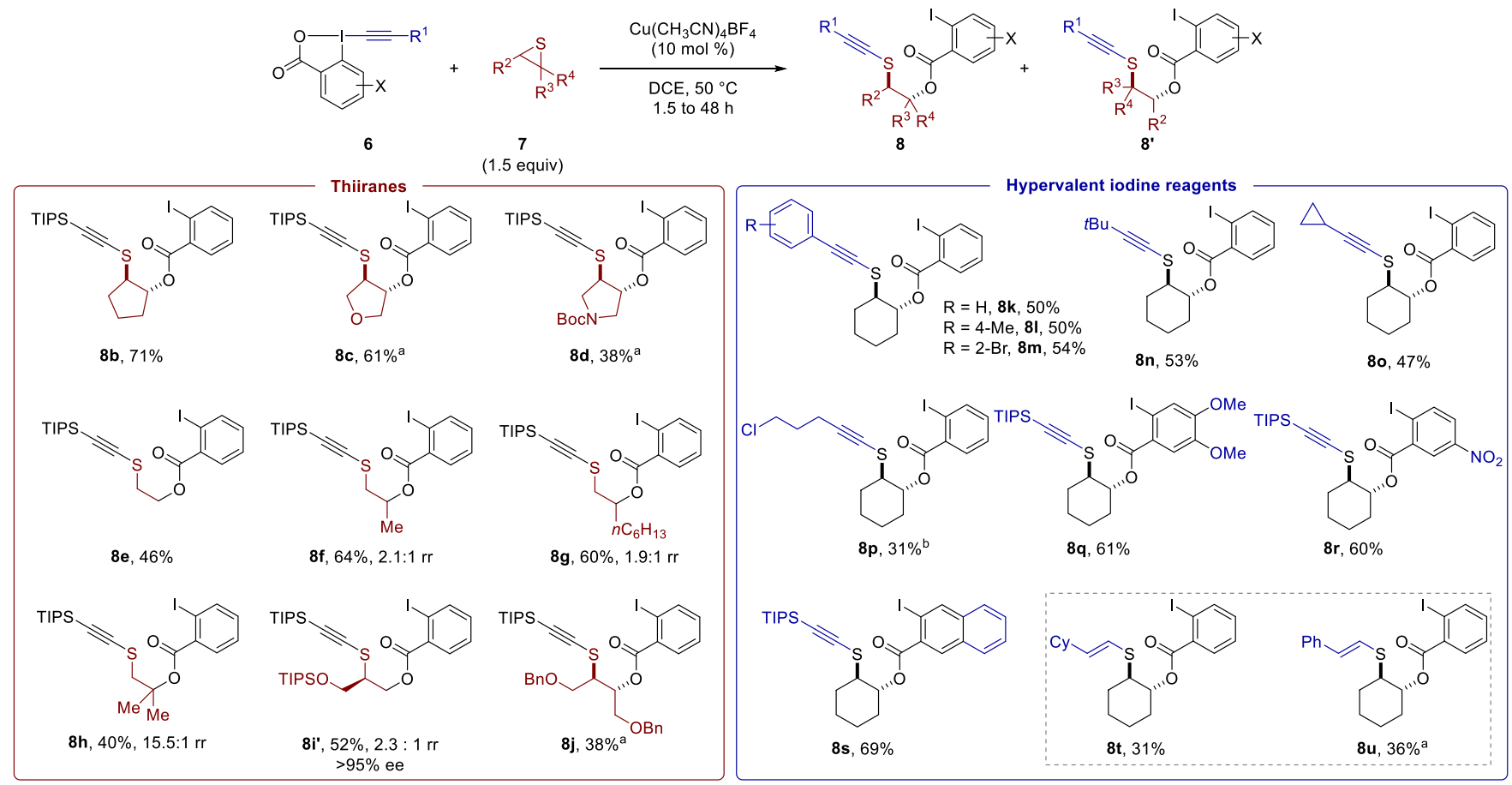

${ }^{*}$ The major regioisomer is drawn; $\mathrm{rr}=$ regioselectivity ratio. Reaction was carried out on $0.2 \mathrm{mmol}$ scale. ${ }^{a}$ Reaction was heated to $70{ }^{\circ} \mathrm{C} .{ }^{b}$ Reaction was stirred at rt.

Scheme 3. Scope Extension to Thietanes and Tetrahydrothiophene*

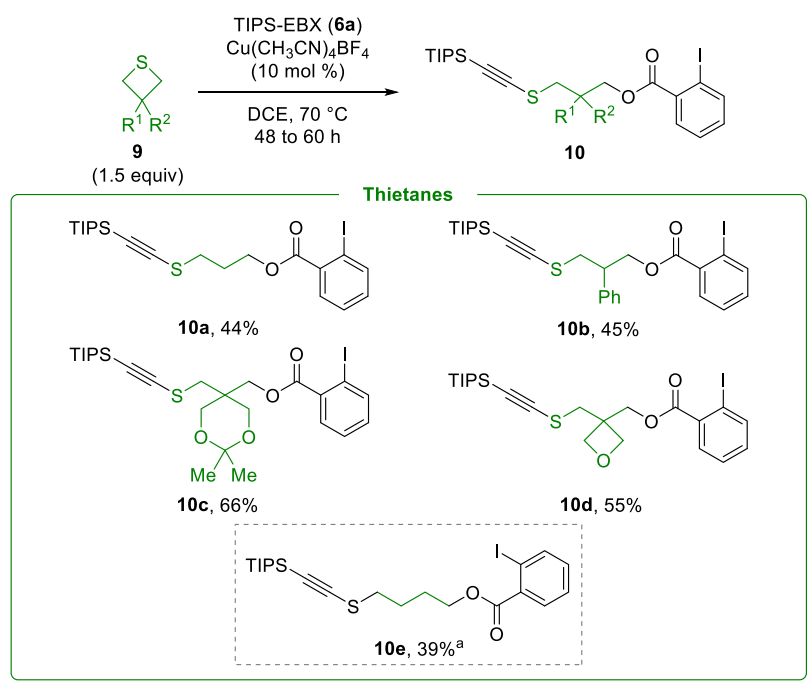

* Reactions were carried out on $0.2 \mathrm{mmol}$ scale. ${ }^{a}$ The reaction mixture was heated to $100{ }^{\circ} \mathrm{C}$ under microwave irradiation.

copper catalyst and sodium benzoate or benzoic acid (Scheme 5, eq 1). No product formation was observed after 3 days, highlighting the importance of the hypervalent iodine reagents for thiirane activation. We applied our standard conditions to cyclohexene oxide (17) (eq 2). Even if epoxides are more prone to a ring-opening reaction due to their higher ring strain, ${ }^{4 \mathrm{~b}}$ no trace of product 18 was observed. This result confirmed the selectivity of the transformation for sulfur heterocycles. The reaction was attempted using iodonium salt $\mathbf{6 v}$ instead of EBX (eq 3). When cesium benzoate or benzoic acid was added to
Scheme 4. Product Modifications

a)<smiles>CC(C)CSC1CCCC[C@@H]1OC(=O)c1ccccc1C#Cc1ccc2ccccc2c1</smiles>
$11,68 \%$<smiles>C#CSC1CCCC[C@@H]1OC(=O)c1ccccc1I</smiles>

$13,97 \%$<smiles>CC(C)C#CSC1CCCC[C@@H]1O</smiles>

$12,86 \%$<smiles>O=C(O[C@H]1CCCC[C@@H]1Sc1cn(Cc2ccccc2)nn1)c1ccccc1I</smiles>

$14,80 \%$ b)

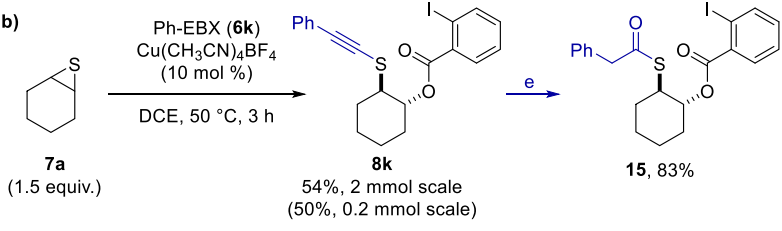

${ }^{a}$ Conditions: (a) 8a (1.0 equiv), 2-ethynylnaphthalene (2.0 equiv), $\mathrm{Pd}\left(\mathrm{PPh}_{3}\right)_{2} \mathrm{Cl}_{2}(10 \mathrm{~mol} \%), \mathrm{CuI}(20 \mathrm{~mol} \%), \mathrm{Et}_{3} \mathrm{~N}(30 \mathrm{mM}), 40{ }^{\circ} \mathrm{C}$, $2.5 \mathrm{~h}$; (b) 8a (1.0 equiv), $\mathrm{K}_{2} \mathrm{CO}_{3}$ (2.5 equiv), $\mathrm{EtOH}(0.1 \mathrm{M}), 45^{\circ} \mathrm{C}$, $30 \mathrm{~h}$; (c) $8 \mathrm{a}$ (1.0 equiv), TBAF (1.2 equiv), THF $(80 \mathrm{mM}), 0{ }^{\circ} \mathrm{C}, 1 \mathrm{~h}$; (d) 13 (1.0 equiv), $\mathrm{BnN}_{3}$ (1.2 equiv), $\mathrm{Cu}\left(\mathrm{H}_{2} \mathrm{O}\right)_{5} \mathrm{SO}_{4}(10 \mathrm{~mol} \%$ ), sodium ascorbate $(20 \mathrm{~mol} \%), \mathrm{CHCl}_{3} / \mathrm{H}_{2} \mathrm{O} 15: 1(60 \mathrm{mM}), \mathrm{rt}, 24 \mathrm{~h}$; (e) $8 \mathbf{k}$ (1.0 equiv), PTSA (1.0 equiv), $\mathrm{SiO}_{2}$ (15.0 equiv), $\mathrm{CH}_{2} \mathrm{Cl}_{2}(0.2$ M), $40{ }^{\circ} \mathrm{C}, 24 \mathrm{~h}$.

replace the missing nucleophile, the desired product was formed only in trace amounts. The addition of a radical scavenger led to the formation of the desired product $8 \mathbf{a}$ with a decreased yield (eq 4). No TEMPO adducts were detected. Nevertheless, a radical pathway cannot be excluded at this stage, as such intermediates may be too unstable to be isolated. 
Scheme 5. Additional Experiments for Mechanism Elucidation

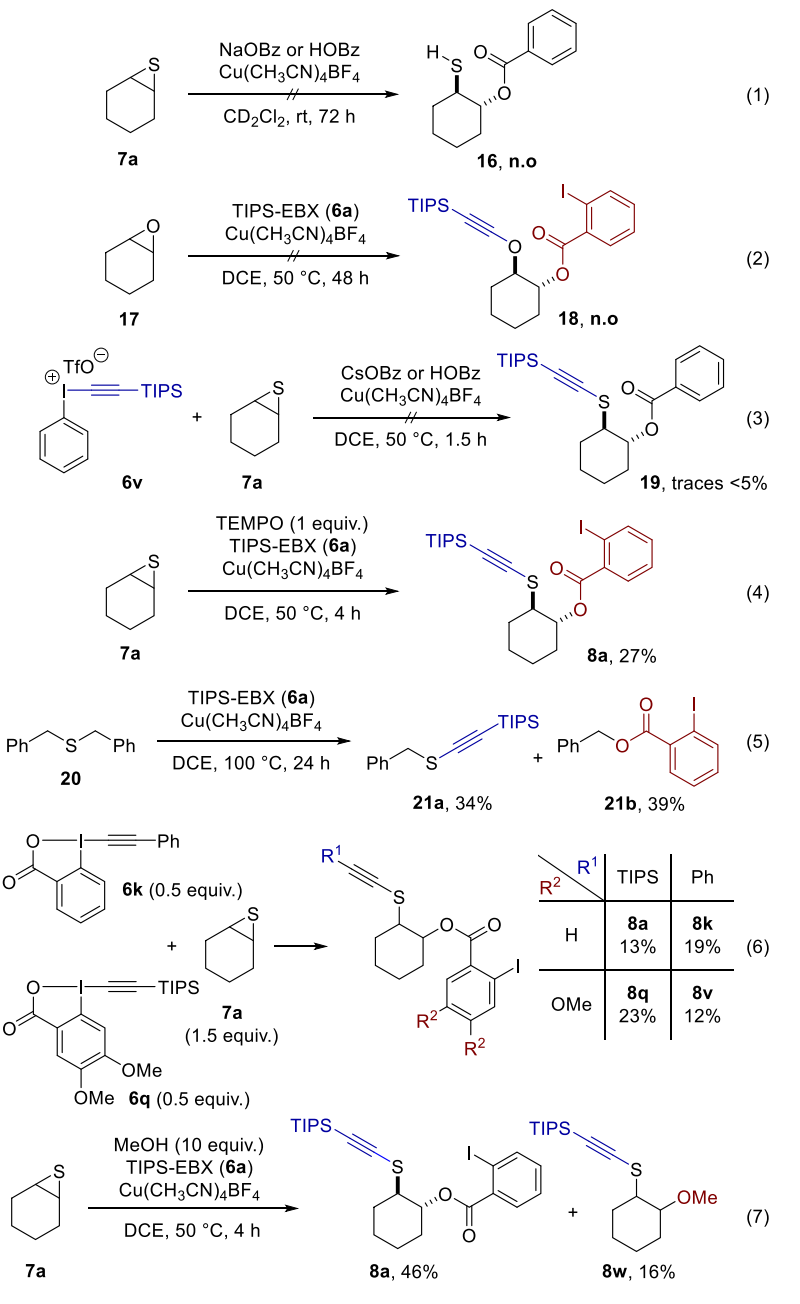

Considering the successful ring opening of nonstrained tetrahydrothiophene (Scheme 3, 10e), we wondered if noncyclic thioethers could be cleaved using our method. We were pleased to see that dibenzyl sulfide 20 reacted to afford the corresponding thioalkyne $\mathbf{2 1} \mathbf{a}$ and benzyl ester $\mathbf{2 1} \mathbf{b}$ in moderate yields at $100{ }^{\circ} \mathrm{C}$ (eq 5). A competitive experiment was carried out with $\mathbf{6 k}$ and $\mathbf{6 q}$ possessing different alkynes and iodobenzoic cores (eq 6). In total, four different products were isolated: the expected products $\mathbf{8 k}$ and $\mathbf{8 q}$ and the crossover products $\mathbf{8 a}$ and $8 \mathbf{v}$ bearing one functional group from each reagent. This showed that external addition can occur but is less favored ( $\sim 1: 2$ ratio). Indeed, when the reaction was performed in the presence of an excess of methanol, ether product $8 \mathbf{w}$ could be obtained in $16 \%$ yield together with $46 \%$ of $8 \mathrm{a}$ (eq 7$)$. $^{20}$

Based on these results, we propose a possible reaction mechanism in Scheme 6. First, the copper(I) catalyst activates EBX reagent 6. Two different modes of activation could be envisaged: formation of the iodonium salt II or oxidative transfer to generate the copper(III) complex III. ${ }^{21}$ In the former case, activated iodonium salt II would react directly with cyclohexene sulfide (7a) to give sulfonium IV. Both a concerted $\alpha$-additionelimination or a $\beta$-addition $/ \alpha$-elimination/1,2-shift pathway could be considered. ${ }^{22}$ In the latter case, coordination of the copper(III) center followed by reductive elimination would lead to sulfonium IV. ${ }^{23}$ At this stage, exchange of carboxylates could happen. Sulfonium IV then undergoes a ring opening by
Scheme 6. Proposed Speculative Mechanism

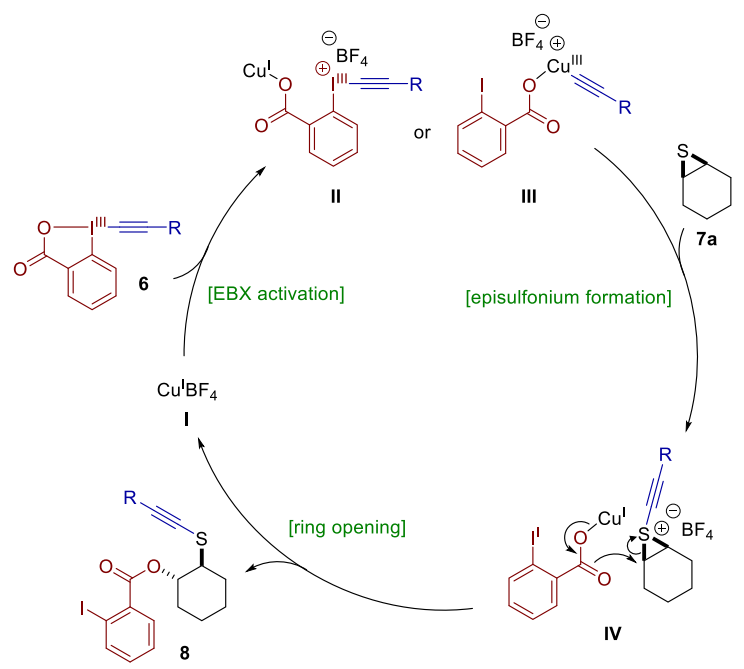

nucleophilic attack of the copper carboxylate, affording the desired product $\mathbf{8}$ and regenerating the initial copper catalyst $\mathbf{I}$. The product formed has a relative trans configuration resulting from a $\mathrm{SN}_{2}$ attack of the carboxylate.

In summary, we have described an atom-efficient coppercatalyzed ring opening of thiiranes and thietanes through the use of hypervalent iodine reagents. The transformation works with different cheap copper sources at a broad range of concentrations and temperatures. In the case of unsymmetrical episulfides, the product resulting from the addition on the carbon-bearing substituents stabilizing better a partial positive charge was observed. Based on the relevant literature and our control experiments, we propose a speculative reaction mechanism involving formation of an episulfonium intermediate for $\mathrm{C}-\mathrm{S}$ bond activation.

\section{ASSOCIATED CONTENT}

\section{Supporting Information}

The Supporting Information is available free of charge at https://pubs.acs.org/doi/10.1021/acs.orglett.9b04157.

Experimental procedures and analytical data for all new compounds (PDF)

\section{Accession Codes}

CCDC 1962904 contains the supplementary crystallographic data for this paper. These data can be obtained free of charge via www.ccdc.cam.ac.uk/data_request/cif, or by emailing data request@ccdc.cam.ac.uk, or by contacting The Cambridge Crystallographic Data Centre, 12 Union Road, Cambridge CB2 1EZ, UK; fax: +44 1223336033.

\section{AUTHOR INFORMATION}

\section{Corresponding Author}

*E-mail: jerome.waser@epfl.ch. ORCID

Jerome Waser: 0000-0002-4570-914X

\section{Author Contributions}

†J.B. and G.P. contributed equality to this work.

\section{Notes}

The authors declare no competing financial interest. 


\section{ACKNOWLEDGMENTS}

We thank the Swiss National Science Foundation (Grant No. 200020 182798) and the Institute of Chemistry and Chemical Engineering at EPFL (Master grant for J.B.) for financial support. Dr. Rosario Scopelliti and Dr. Farzaneh Fadaei Tirani (ISIC, EPFL) are acknowledged for the X-ray study.

\section{REFERENCES}

(1) Murphree, S. S. Three-Membered Heterocycles. Structure and Reactivity. In Modern Heterocyclic Chemistry; Alvarez-Builla, J., Vaquero, J. J., Barluenga, J., Eds.; Wiley-VCH: Weinheim, Germany, 2011; pp 11-162.

(2) (a) Hu, X. E. Nucleophilic Ring Opening of Aziridines. Tetrahedron 2004, 60, 2701-2743. (b) Lu, P. Recent Developments in Regioselective Ring Opening of Aziridines. Tetrahedron 2010, 66, 2549-2560. (c) Akhtar, R.; Naqvi, S. A. R.; Zahoor, A. F.; Saleem, S. Nucleophilic Ring Opening Reactions of Aziridines. Mol. Diversity 2018, 22, 447-501.

(3) (a) Malapit, C. A.; Howell, A. R. Recent Applications of Oxetanes in the Synthesis of Heterocyclic Compounds. J. Org. Chem. 2015, 80, 8489-8495. (b) Bull, J. A.; Croft, R. A.; Davis, O. A.; Doran, R.; Morgan, K. F. Oxetanes: Recent Advances in Synthesis, Reactivity, and Medicinal Chemistry. Chem. Rev. 2016, 116, 12150-12233. (c) Ahmad, S.; Yousaf, M.; Mansha, A.; Rasool, N.; Zahoor, A. F.; Hafeez, F.; Rizvi, S. M. A. Ring-Opening Reactions of Oxetanes: A Review of Methodology Development and Synthetic Applications. Synth. Commun. 2016, 46, 1397-1416.

(4) (a) Sander, M. Thiiranes. Chem. Rev. 1966, 66, 297-339. (b) Chew, W.; Harpp, D. N. Recent Aspects of Thiirane Chemistry. Sulfur Rep. 1993, 15, 1-39.

(5) (a) Rousseau, G.; Robin, S. Four-Membered Heterocycles: Structure and Reactivity. In Modern Heterocyclic Chemistry; AlvarezBuilla, J., Vaquero, J. J., Barluenga, J., Eds.; Wiley-VCH: Weinheim, Germany, 2011; pp 163-268. (b) Kurgane, B. V.; Giller, S. A. Ring Opening of Thietane. Chem. Heterocycl. Compd. 1971, 7, 557-558. (c) Palmer, D. C.; Taylor, E. C. Thietane Alkylations. A General Synthesis of 3-Halopropyl Benzyl Sulfides. J. Org. Chem. 1986, 51, 846850. (d) Zheng, T.; Tan, J.; Fan, R.; Su, S.; Liu, B.; Tan, C.; Xu, K. Diverse Ring Opening of Thietanes and Other Cyclic Sulfides: An Electrophilic Aryne Activation Approach. Chem. Commun. 2018, 54, 1303-1306.

(6) Cremlyn, R. J. W. An Introduction to Organosulfur Chemistry; Wiley: Chichester, 1996.

(7) (a) Rayner, C. M. Synthetic Transformations Involving Thiiranium Ion Intermediates. In Organosulfur Chemistry; Elsevier, 1995; Chapter 3, Vol. 1, pp 89-131. (b) The Chemistry of the Sulphonium Group; Stirling, C. J. M., Ed. The Chemistry of Functional Groups; Wiley: Chichester, 1981. (c) Lin, S.; Jacobsen, E. N. ThioureaCatalysed Ring Opening of Episulfonium Ions with Indole Derivatives by Means of Stabilizing Non-Covalent Interactions. Nat. Chem. 2012, 4, 817-824. (d) Denmark, S. E.; Jaunet, A. Catalytic, Enantioselective, Intramolecular Carbosulfenylation of Olefins. J. Am. Chem. Soc. 2013, 135, 6419-6422. (e) Denmark, S. E.; Hartmann, E.; Kornfilt, D. J. P.; Wang, H. Mechanistic, Crystallographic, and Computational Studies on the Catalytic, Enantioselective Sulfenofunctionalization of Alkenes. Nat. Chem. 2014, 6, 1056-1064. (f) Hartmann, E.; Denmark, S. E. Structural, Mechanistic, Spectroscopic, and Preparative Studies on the Lewis Base Catalyzed, Enantioselective Sulfenofunctionalization of Alkenes. Helv. Chim. Acta 2017, 100, No. e1700158.

(8) Dong, J.; Du, H.; Xu, J. Synthesis of Functionalized Thietanes via Electrophilic Carbenoid-Induced Ring Expansion of Thiiranes with Sulfonium Acylmethylides as Carbene Precursors. J. Org. Chem. 2019, 84, 10724-10739.

(9) Frei, P.; Jones, D. H.; Kay, S. T.; McLellan, J. A.; Johnston, B. F.; Kennedy, A. R.; Tomkinson, N. C. O. Regioselective Reaction of Heterocyclic $N$-Oxides, an Acyl Chloride, and Cyclic Thioethers. J. Org. Chem. 2018, 83, 1510-1517.
(10) Kaiser, D.; Klose, I.; Oost, R.; Neuhaus, J.; Maulide, N. BondForming and -Breaking Reactions at Sulfur(IV): Sulfoxides, Sulfonium Salts, Sulfur Ylides, and Sulfinate Salts. Chem. Rev. 2019, 119, 87018780.

(11) Ochiai, M.; Nagaoka, T.; Sueda, T.; Yan, J.; Chen, D. W.; Miyamoto, K. Synthesis of 1-Alkynyl(diphenyl)onium Salts of Group 16 Elements via Heteroatom Transfer Reaction of 1-Alkynyl(Phenyl)23-Iodanes. Org. Biomol. Chem. 2003, 1, 1517-1521.

(12) (a) Frei, R.; Waser, J. A Highly Chemoselective and Practical Alkynylation of Thiols. J. Am. Chem. Soc. 2013, 135, 9620-9623. (b) Frei, R.; Wodrich, M. D.; Hari, D. P.; Borin, P. A.; Chauvier, C.; Waser, J. Fast and Highly Chemoselective Alkynylation of Thiols with Hypervalent Iodine Reagents Enabled through a Low Energy Barrier Concerted Mechanism. J. Am. Chem. Soc. 2014, 136, 16563-16573.

(13) (a) Hari, D. P.; Caramenti, P.; Waser, J. Cyclic Hypervalent Iodine Reagents: Enabling Tools for Bond Disconnection via Reactivity Umpolung. Acc. Chem. Res. 2018, 51, 3212-3225. (b) Hari, D. P.; Nicolai, S.; Waser, J. Alkynylations and Vinylations. PATAI'S Chemistry of Functional Groups; Wiley, 2018.

(14) Recent examples of atom-economical reactions with hypervalent iodine reagents: (a) Modha, S. G.; Greaney, M. F. Atom-Economical Transformation of Diaryliodonium Salts: Tandem C-H and N-H Arylation of Indoles. J. Am. Chem. Soc. 2015, 137, 1416-1419. (b) Buendia, J.; Darses, B.; Dauban, P. Tandem Catalytic C(sp3)-H Amination/Sila-Sonogashira-Hagihara Coupling Reactions with Iodine Reagents. Angew. Chem., Int. Ed. 2015, 54, 5697-5701. (c) Hari, D. P.; Waser, J. Copper-Catalyzed Oxy-Alkynylation of Diazo Compounds with Hypervalent Iodine Reagents. J. Am. Chem. Soc. 2016, 138, 2190-2193. (d) Wang, M.; Wei, J.; Fan, Q.; Jiang, X. $\mathrm{Cu}(\mathrm{II})$-Catalyzed Sulfide Construction: Both Aryl Groups Utilization of Intermolecular and Intramolecular Diaryliodonium Salt. Chem. Commun. 2017, 53, 2918-2921. (e) Pisella, G.; Gagnebin, A.; Waser, J. Copper-Catalyzed Insertion of Diazo Compounds into Vinyl Hypervalent Iodine Reagents to Generate Allylic Esters. ChemRxiv 2019, DOI: 10.26434/chemrxiv.7892513.v1. Review: (f) Boelke, A.; Finkbeiner, P.; Nachtsheim, B. J. Atom-Economical Group-Transfer Reactions with Hypervalent Iodine Compounds. Beilstein J. Org. Chem. 2018, 14, 1263-1280. (g) Wang, M.; Chen, S.; Jiang, X. AtomEconomical Applications of Diaryliodonium Salts. Chem. - Asian J. 2018, 13, 2195-2207.

(15) (a) Takada, N.; Umemura, N.; Suenaga, K.; Uemura, D. Structural Determination of Pteriatoxins A, B and C, Extremely Potent Toxins from the Bivalve Pteria Penguin. Tetrahedron Lett. 2001, 42, 3495-3497. (b) Wu, H.; Zhang, Y.; Huang, J.; Zhang, Y.; Liu, G.; Sun, N.; Yu, Z.; Zhou, Y. Clinical Trial of Arotinolol in the Treatment of Hypertension: Dippers vs. Non-Dippers. Hypertens. Res. 2001, 24, 605-610. (c) Capra, V.; Thompson, M. D.; Sala, A.; Cole, D. E.; Folco, G.; Rovati, G. E. Cysteinyl-Leukotrienes and Their Receptors in Asthma and Other Inflammatory Diseases: Critical Update and Emerging Trends. Med. Res. Rev. 2007, 27, 469-527. (d) de Castro, M. V.; Ióca, L. P.; Williams, D. E.; Costa, B. Z.; Mizuno, C. M.; Santos, M. F. C.; de Jesus, K.; Ferreira, É. L. F.; Seleghim, M. H. R.; Sette, L. D.; Pereira Filho, E. R.; Ferreira, A. G.; Gonçalves, N. S.; Santos, R. A.; Patrick, B. O.; Andersen, R. J.; Berlinck, R. G. S. Condensation of Macrocyclic Polyketides Produced by Penicillium Sp. DRF2 with Mercaptopyruvate Represents a New Fungal Detoxification Pathway. J. Nat. Prod. 2016, 79, 1668-1678.

(16) (a) Marakalala, M. B.; Mmutlane, E. M.; Kinfe, H. H. $\beta$-Hydroxy Sulfides and Their Syntheses. Beilstein J. Org. Chem. 2018, 14, 16681692. (b) Iranpoor, N.; Owji, J. Efficient, Mild, and Regioselective Conversion of Thiiranes to Alkoxy and Acetoxy Disulphides and Dithianes with Ce(IV) Based Oxidants. Tetrahedron 1991, 47, 149154. (c) Iranpoor, N.; Shekarriz, M.; Shiriny, F. Highly Efficient, Regioand Stereoselective Ring Opening of Epoxides and Thiiranes with $\mathrm{Ce}(\mathrm{OTf})_{4}$. Synth. Commun. 1998, 28, 347-366. (d) Iranpoor, N.; Firouzabadi, H.; Chitsazi, M.; Ali Jafari, A. Reactions of Epoxides and Episulfides with Electrophilic Halogens. Tetrahedron 2002, 58, 70377042. (e) Movsumzade, M. M.; Shatirova, M. I.; Dzhafarova, U. Sh.; Niyazova, N. K. Investigation of Chemical Properties and Antimicrobial 
Activity of Acetylene Glycidyl Ethers. Russ. J. Gen. Chem. 2018, 88, 389-392.

(17) (a) Rowell, R. M.; Whistler, R. L. Derivatives of A-DGlucothiopyranose. J. Org. Chem. 1966, 31, 1514-1516. (b) CalvoFlores, F. G.; García-Mendoza, P.; Hernández-Mateo, F.; Isac-García, J.; Santoyo-González, F. Applications of Cyclic Sulfates of Vic -Diols: Synthesis of Episulfides, Olefins, and Thio Sugars. J. Org. Chem. 1997, 62, 3944-3961. (c) Liao, X.; Větvička, V.; Crich, D. Synthesis and Evaluation of 1,5-Dithia- $\mathrm{d}$-Laminaribiose, Triose, and Tetraose as Truncated $\beta$-(1 $\rightarrow 3)$-Glucan Mimetics. J. Org. Chem. 2018, 83, 1489414904.

(18) We also attempted the use of in situ-generated unstable cyclohexene selenide. See: Chan, T. H.; Finkenbine, J. R. Reaction of Epoxides with Phosphine Selenides and Trifluoroacetic Acid. Evidence for the Formation of Episelenides. Tetrahedron Lett. 1974, 15, 20912094. However, no product was obtained.

(19) Zelčans, G.; Gervay-Hague, J.; Maulie, I. Ethylene Sulfide. In Encyclopedia of Reagents for Organic Synthesis; John Wiley \& Sons, 2010. (20) The use of an EBX reagent bearing a less nucleophilic 2-iodo-5nitrobenzoate did not increase the product ratio in favor of ether $8 \mathbf{w}$. No reaction was observed when using an ethynylbenziodoxole reagent derived from hexafluoro-2-(2-iodophenyl)propan-2-ol.

(21) (a) Holt, D.; Gaunt, M. J. Copper-Catalyzed Oxy-Alkenylation of Homoallylic Alcohols to Generate Functional Syn-1,3-Diol Derivatives. Angew. Chem., Int. Ed. 2015, 54, 7857-7861. (b) Suero, M. G.; Bayle, E. D.; Collins, B. S. L.; Gaunt, M. J. Copper-Catalyzed Electrophilic Carbofunctionalization of Alkynes to Highly Functionalized Tetrasubstituted Alkenes. J. Am. Chem. Soc. 2013, 135, 5332-5335. (c) Hickman, A. J.; Sanford, M. S. High-Valent Organometallic Copper and Palladium in Catalysis. Nature 2012, 484, 177-185.

(22) Wodrich, M. D.; Caramenti, P.; Waser, J. Alkynylation of Thiols with Ethynylbenziodoxolone (EBX) Reagents: $\alpha$ - or $\beta$ - $\pi$-Addition? Org. Lett. 2016, 18, 60-63.

(23) Another plausible mechanism not depicted here would involve non-oxidative alkyne transfer from iodine to copper, resulting in an iodine(III)-activated $\mathrm{Cu}(\mathrm{I})$ acetylide, similarly to the computed mechanism for the gold-catalyzed alkynylation of indoles: Ariafard, A. A Density Functional Theory (DFT) Mechanistic Study of Gold(I)Catalyzed Alkynylation of the Indole and Pyrrole Substrates, Using a Hypervalent Iodine Reagent. ACS Catal. 2014, 4, 2896-2907. 
Supporting Information for

\title{
Copper-Catalyzed Oxy-Alkynylation of C-S Bonds in Thiiranes and Thiethanes with Hypervalent Iodine Reagents
}

\author{
Julien Borrel, ${ }^{\dagger}$ Guillaume Pisella, ${ }^{\dagger}$ and Jerome Waser* ${ }^{* \dagger}$
}

These authors contributed equality to this work. "Laboratory of Catalysis and Organic Synthesis, Institute of Chemical Sciences and Engineering, Ecole Polytechnique Fédérale de Lausanne, EPFL SB ISIC LCSO, BCH 1402, 1015 Lausanne, Switzerland. jerome.waser@epfl.ch

(103 pages) 


\section{Table of Contents}

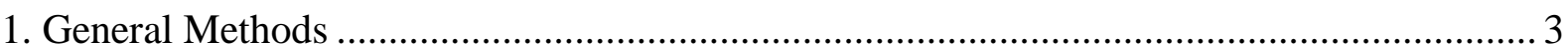

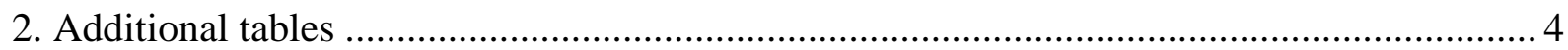

3. Preparation of Hypervalent Iodine Reagents............................................................. 6

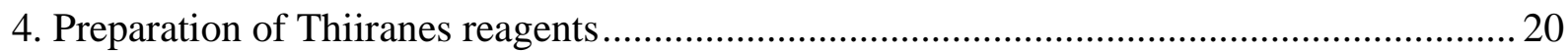

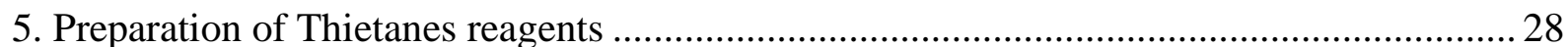

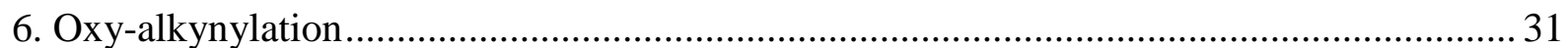

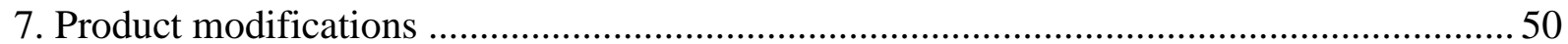

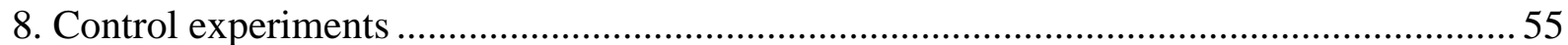

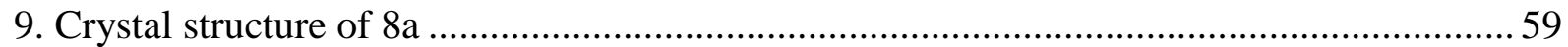

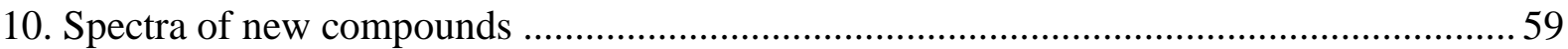




\section{General Methods}

All reactions were carried out under an atmosphere of nitrogen, unless stated otherwise. For quantitative flash chromatography technical grade solvents were used. For flash chromatography for analysis, HPLC grade solvents from Sigma-Aldrich were used. THF, $\mathrm{Et}_{2} \mathrm{O}$, $\mathrm{CH}_{3} \mathrm{CN}$, toluene, hexane and $\mathrm{CH}_{2} \mathrm{Cl}_{2}$ were dried by passage over activated alumina under nitrogen atmosphere $\left(\mathrm{H}_{2} \mathrm{O}\right.$ content $<10 \mathrm{ppm}$, Karl-Fischer titration). All chemicals were purchased from Acros, Aldrich, Fluka, VWR, Fluorochem or Merck and used used as such unless stated otherwise. Chromatographic purification was performed as flash chromatography using Silicycle silica 40-63, $60 \AA$, using the solvents indicated as eluent with 0.1-0.5 bar pressure. TLC was performed on Pre-coated TLC sheets ALUGRAM ${ }^{\circledR}$ Xtra SIL G/UV 254 and visualized with UV light and potassium permanganate or $p$-anisaldehyde stain. ${ }^{1} \mathrm{H}-\mathrm{NMR}$ spectra were recorded on a Bruker DPX-400 $400 \mathrm{MHz}$ spectrometer in chloroform-d. All signals are reported in ppm with the internal chloroform signal at $7.26 \mathrm{ppm}$. The data is being reported as $(\mathrm{s}=$ singlet, $\mathrm{d}=$ doublet, $\mathrm{t}=$ triplet, $\mathrm{q}=$ quadruplet, $\mathrm{qi}=$ quintet, $\mathrm{m}=$ multiplet or unresolved, bs = broad signal, coupling constant(s) in $\mathrm{Hz}$, integration, assignment). ${ }^{13} \mathrm{C}-\mathrm{NMR}$ spectra were recorded with $\{1 \mathrm{H}\}$ decoupling on a Bruker DPX-400 $101 \mathrm{MHz}$ spectrometer in chloroform-d unless otherwise stated. All signals are reported in ppm with the internal chloroform signal at $77.0 \mathrm{ppm}$ as standard unless otherwise stated. Infrared spectra were recorded on a JASCO FT-IR B4100 or a Brucer Alpha-P spectrophotometer with an ATR device and a $\mathrm{ZnSe}$ prisma and are reported $\mathrm{as}^{-1}$ ( $\mathrm{w}=$ weak, $\mathrm{m}=$ medium, $\mathrm{s}=$ strong, $\mathrm{br}=$ broad). High resolution mass spectrometric measurements were performed by the mass spectrometry service of ISIC at the EPFL on a MICROMASS (ESI) QTOF. HPLC measurements were done on a Agilent 1260 Infinity autosampler using a CHIRALPAK IBN or IC column from DAICEL Chemical. Samples were prepared in a 90/10 hexane/isopropanol mixture, before being submitted in chiral HPLC. Microwave reactions were run in a Biotage Initiator 2.0. Cyclohexene sulfide (85\%, technical grade) was purchased from Sigma-Aldrich and purified by distillation prior to use. 


\section{Additional tables}

Table S1. Initial optimization. ${ }^{a}$

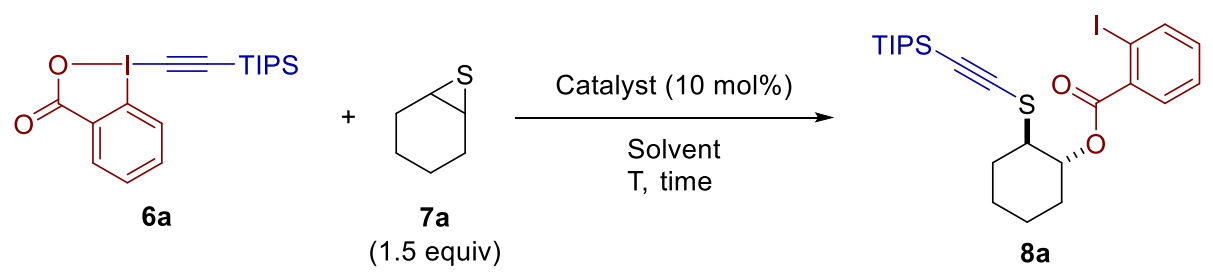

\begin{tabular}{|c|c|c|c|c|c|}
\hline entry & catalyst & solvent & $\mathrm{T}\left({ }^{\circ} \mathrm{C}\right)$ & time (h) & isolated yield \\
\hline 1 & None & THF & 70 & 24 & $\operatorname{traces}^{b}$ \\
\hline $2^{c}$ & TMSCl & THF & 30 & 4 & not observed \\
\hline 3 & $\mathrm{Cu}\left(\mathrm{CH}_{3} \mathrm{CN}\right)_{4} \mathrm{BF}_{4}$ & THF & $\mathrm{rt}$ & 24 & 53 \\
\hline 4 & $\mathrm{Cu}\left(\mathrm{CH}_{3} \mathrm{CN}\right)_{4} \mathrm{BF}_{4}$ & $\mathrm{NO}_{2} \mathrm{Me}$ & $\mathrm{rt}$ & 24 & 56 \\
\hline 5 & $\mathrm{Cu}\left(\mathrm{CH}_{3} \mathrm{CN}\right)_{4} \mathrm{BF}_{4}$ & $\mathrm{AcOEt}$ & $\mathrm{rt}$ & 24 & 49 \\
\hline 6 & $\mathrm{Cu}\left(\mathrm{CH}_{3} \mathrm{CN}\right)_{4} \mathrm{BF}_{4}$ & acetone & $\mathrm{rt}$ & 24 & 56 \\
\hline 7 & $\mathrm{Cu}\left(\mathrm{CH}_{3} \mathrm{CN}\right)_{4} \mathrm{BF}_{4}$ & dioxane & $\mathrm{rt}$ & 24 & 64 \\
\hline 8 & $\mathrm{Cu}\left(\mathrm{CH}_{3} \mathrm{CN}\right)_{4} \mathrm{BF}_{4}$ & toluene & $\mathrm{rt}$ & 24 & 62 \\
\hline 9 & $\mathrm{Cu}\left(\mathrm{CH}_{3} \mathrm{CN}\right)_{4} \mathrm{BF}_{4}$ & DCE & $\mathrm{rt}$ & 24 & 66 \\
\hline 10 & $\mathrm{Cu}\left(\mathrm{CH}_{3} \mathrm{CN}\right)_{4} \mathrm{BF}_{4}$ & DCE & 50 & 1.5 & 65 \\
\hline 11 & $\mathrm{Cu}\left(\mathrm{CH}_{3} \mathrm{CN}\right)_{4} \mathrm{BF}_{4}$ & DCE & 70 & 1.5 & 61 \\
\hline $12^{d}$ & $\mathrm{Cu}\left(\mathrm{CH}_{3} \mathrm{CN}\right)_{4} \mathrm{BF}_{4}$ & DCE & 100 & 0.5 & 67 \\
\hline 13 & $\mathrm{Cu}\left(\mathrm{CH}_{3} \mathrm{CN}\right)_{4} \mathrm{PF}_{6}$ & DCE & 50 & 1.5 & 66 \\
\hline 14 & $\mathrm{Cu}(\mathrm{OTf})_{2}$ & DCE & 50 & 1.5 & 66 \\
\hline 15 & $\mathrm{CuI}$ & DCE & 50 & 1.5 & 19 \\
\hline 16 & $\mathrm{Cu}(\mathrm{tfacac})_{2}$ & DCE & 50 & 1.5 & 11 \\
\hline 17 & $\mathrm{AuCl}$ & DCE & $\mathrm{rt}$ & 24 & not observed \\
\hline 18 & $\mathrm{TiCl}_{4}$ & DCE & 50 & 24 & not observed \\
\hline 19 & $\mathrm{Sc}(\mathrm{OTf})_{3}$ & DCE & 50 & 24 & not observed \\
\hline 20 & $\mathrm{Zn}(\mathrm{OTf})_{2}$ & DCE & 50 & 24 & not observed \\
\hline 21 & $\mathrm{AgOTf}$ & DCE & 50 & 24 & $\operatorname{traces}^{b}$ \\
\hline
\end{tabular}

${ }^{a}$ Reaction conditions: TIPS-EBX (6a) $(0.1 \mathrm{mmol})$, cyclohexene sulfide $(7 \mathbf{a})(0.15 \mathrm{mmol})$, catalyst $(10 \mathrm{~mol} \%)$, solvent $(0.07 \mathrm{M})$, reactions were carried out under $\mathrm{N}_{2}$ atmosphere. ${ }^{b}$ Observed by NMR. ${ }^{c} 1$ equivalent of TMSCl was used. ${ }^{d}$ Reaction was performed under microwave irradiation. tfacac $=$ trifluoroacetylacetonate. 
Table S2. Attempts to reduce oligomerization ${ }^{a}$

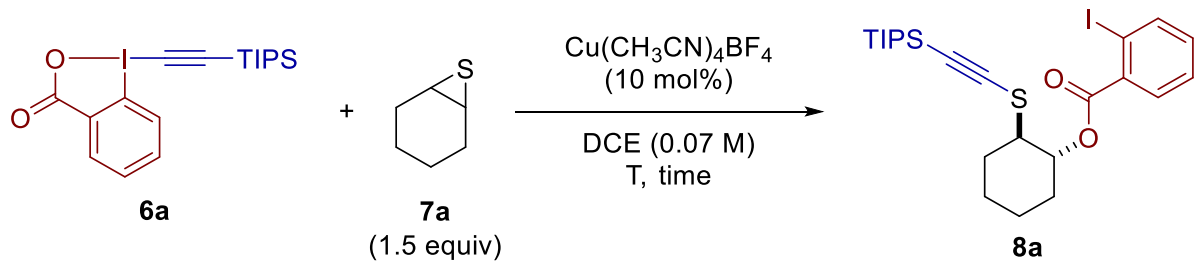

\begin{tabular}{|c|c|c|c|c|}
\hline entry & variation from standard conditions & $\mathrm{T}\left({ }^{\circ} \mathrm{C}\right)$ & time (h) & isolated yield \\
\hline 1 & None & 50 & 1.5 & 65 \\
\hline 2 & $\mathrm{C}=0.02 \mathrm{M}$ & 50 & 1.5 & 65 \\
\hline 3 & $\mathrm{C}=0.15 \mathrm{M}$ & 50 & 1.5 & 65 \\
\hline 4 & $\mathrm{Cu}\left(\mathrm{CH}_{3} \mathrm{CN}\right)_{4} \mathrm{BF}_{4}$ loading $=5 \mathrm{~mol} \%$ & 50 & 3.5 & 65 \\
\hline 5 & $\mathrm{Cu}\left(\mathrm{CH}_{3} \mathrm{CN}\right)_{4} \mathrm{BF}_{4}$ loading $=20 \mathrm{~mol} \%$ & 50 & 1.5 & 53 \\
\hline 6 & + L1 (15 mol\%) & $\mathrm{rt}$ & 24 & 17 \\
\hline 7 & + L1 (15 mol\%) & 50 & 5 & 20 \\
\hline 8 & + $\mathbf{L 2}(15 \mathrm{~mol} \%)$ & 50 & 1.5 & not observed \\
\hline 9 & Ratio $6 \mathbf{a} / 7 \mathbf{a}=1: 2$ & $\mathrm{rt}$ & 24 & 62 \\
\hline 10 & Ratio $6 \mathbf{a} / 7 \mathbf{a}=1: 2.5$ & $\mathrm{rt}$ & 24 & 61 \\
\hline 11 & Ratio $6 \mathbf{a} / 7 \mathbf{a}=1: 1$ & $\mathrm{rt}$ & 24 & 55 \\
\hline 12 & Ratio $\mathbf{6 a} / 7 \mathbf{a}=1.5: 1$ & $\mathrm{rt}$ & 24 & 56 \\
\hline 13 & Ratio $\mathbf{6 a} / 7 \mathbf{a}=2: 1$ & $\mathrm{rt}$ & 24 & 45 \\
\hline 14 & Ratio $\mathbf{6 a} / \mathbf{7 a}=2.5: 1$ & $\mathrm{rt}$ & 24 & 46 \\
\hline 15 & $\begin{array}{c}+2 \text {-iodobenzoic acid ( } 1 \text { equiv.), dropwise addition } \\
\text { of } \mathbf{7 a}\end{array}$ & 50 & 1.5 & 66 \\
\hline
\end{tabular}

${ }^{a}$ Reaction conditions: TIPS-EBX (6a) $(0.1 \mathrm{mmol})$, cyclohexene sulfide (7a) $(0.15 \mathrm{mmol})$, catalyst $(10 \mathrm{~mol} \%)$, solvent $(0.07 \mathrm{M})$, reactions were carried out under $\mathrm{N}_{2}$ atmosphere. 


\section{Preparation of Hypervalent Iodine Reagents}

The synthesis of reagents had already been described before by our group. The procedures are taken from the indicated publications to facilitate reproduction of the results by having all data in the same file.

\section{1-Hydroxy-1,2-benziodoxol-3-(1H)-one (23)}

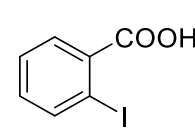

22

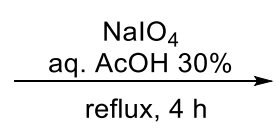

reflux, $4 \mathrm{~h}$

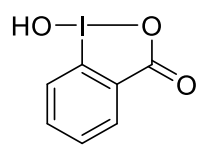

23

Following a reported procedure, ${ }^{1} \mathrm{NaIO}_{4}(7.24 \mathrm{~g}, 33.8 \mathrm{mmol}, 1.05$ equiv) and 2-iodobenzoic acid (22) (8.00 g, $32.2 \mathrm{mmol}, 1.00$ equiv) were suspended in $30 \%(\mathrm{v} / \mathrm{v})$ aq. AcOH (48 mL). The mixture was vigorously stirred and refluxed for $4 \mathrm{~h}$. The reaction mixture was then diluted with cold water $(180 \mathrm{~mL})$ and allowed to cool to room temperature, protecting it from light. After 1 $\mathrm{h}$, the crude product was collected by filtration, washed on the filter with ice water $(3 \mathrm{x} 20 \mathrm{~mL})$ and acetone $(3 \times 20 \mathrm{~mL})$, and air-dried in the dark to give the pure product $\mathbf{2 3}(8.3 \mathrm{~g}, 31 \mathrm{mmol}$, 98\%) as a white solid. ${ }^{1} \mathrm{H} \mathrm{NMR}\left(400 \mathrm{MHz},\left(\mathrm{CD}_{3}\right)_{2} \mathrm{SO}\right): \delta 8.02(\mathrm{dd}, J=7.7,1.4 \mathrm{~Hz}, 1 \mathrm{H}, \mathrm{ArH})$, $7.97(\mathrm{~m}, 1 \mathrm{H}, \mathrm{ArH}), 7.85(\mathrm{dd}, J=8.2,0.7 \mathrm{~Hz}, 1 \mathrm{H}, \mathrm{ArH}), 7.71(\mathrm{td}, J=7.6,1.2 \mathrm{~Hz}, 1 \mathrm{H}, \mathrm{ArH}) ;{ }^{13} \mathrm{C}$ NMR (100 MHz, (CD $\left.)_{2} \mathrm{SO}\right): \delta 167.7,134.5,131.5,131.1,130.4,126.3,120.4$; IR v 3083 (w), 3060 (w), 2867 (w), 2402 (w), 1601 (m), 1585 (m), 1564 (m), 1440 (m), 1338 (s), 1302 (m), 1148 (m), 1018 (w), 834 (m), 798 (w), 740 (s), 694 (s), 674 (m), 649 (m). The values of the NMR spectra are in accordance with reported literature data. ${ }^{1}$

\section{Triisopropylsilyl trimethylsilylacetylene (25)}

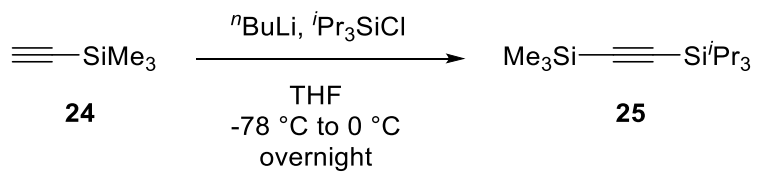

\footnotetext{
${ }^{1}$ L. Kraszkiewicz, L. Skulski, Arkivoc 2003, 2003, 120.
} 
Following a reported procedure, ${ }^{2}{ }^{n} \mathrm{BuLi}(2.5 \mathrm{M}$ in hexanes, $12.0 \mathrm{~mL}, 29.9 \mathrm{mmol}, 0.98$ equiv) was added dropwise to a stirred solution of ethynyltrimethylsilane (24) (3.0 g, $30 \mathrm{mmol}, 1.0$ equiv) in THF ( $48 \mathrm{~mL}$ ) at $-78{ }^{\circ} \mathrm{C}$. The mixture was then warmed to $0{ }^{\circ} \mathrm{C}$ and stirred for $5 \mathrm{~min}$. The mixture was then cooled back to $-78{ }^{\circ} \mathrm{C}$ and chlorotriisopropylsilane $(6.4 \mathrm{~mL}, 30 \mathrm{mmol}$, 1.0 equiv) was added dropwise. The mixture was then allowed to warm to room temperature and stirred overnight. A saturated solution of ammonium chloride $(40 \mathrm{~mL})$ was added, and the reaction mixture was extracted with diethyl ether $(2 \times 60 \mathrm{~mL})$. The organic layer was washed with water and brine, then dried over $\mathrm{MgSO}_{4}$, filtered and concentrated under reduced pressure to obtain a colorless liquid which was further purified by Kugelrohr distillation $\left(56-57{ }^{\circ} \mathrm{C} / 0.25\right.$ $\mathrm{mm}$ of $\mathrm{Hg}$ ) to yield 25 (7.16 g, $28.0 \mathrm{mmol}, 92 \%$ yield) as a colorless liquid. ${ }^{1} \mathrm{H}$ NMR (400 MHz, $\mathrm{CDCl}_{3}$ ): $\delta 1.08$ (m, 21H, TIPS), 0.18 (s, 9H, TMS); IR v 2959 (m), 2944 (m), 2896 (w), $2867(\mathrm{~m}), 1464$ (w), 1385 (w), 1250 (m), 996 (w), 842 (s), 764 (s), 675 (m), 660 (m). The values of the NMR spectra are in accordance with reported literature data. ${ }^{2}$

\section{1-[(Triiso-propylsilyl)ethynyl]-1,2-benziodoxol-3(1H)-one (6a)}

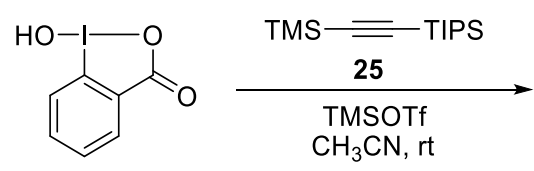

23

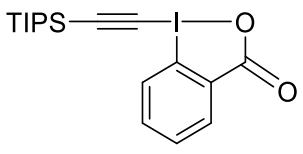

$6 \mathbf{a}$

Following a reported procedure, ${ }^{3}$ 2-iodosylbenzoic acid (23) $(21.7 \mathrm{~g}, 82.0 \mathrm{mmol}, 1.00$ equiv) was charged in oven-dried three-neck 1L flask equipped with a magnetic stirrer. After 3 vacuum/nitrogen cycles, anhydrous acetonitrile $(500 \mathrm{~mL})$ was added via canula and cooled to $0{ }^{\circ} \mathrm{C}$. Trimethylsilyltriflate $(16.4 \mathrm{~mL}, 90.0 \mathrm{mmol}, 1.10$ equiv) was added dropwise via a dropping funnel over $30 \mathrm{~min}$ (no temperature increase was observed). After $15 \mathrm{~min}$, (trimethylsilyl)(triisopropylsilyl)acetylene (25) (23.0 g, $90.0 \mathrm{mmol}, 1.10$ equiv) was added via canula over $15 \mathrm{~min}$ (no temperature increase was observed). After $30 \mathrm{~min}$, the suspension became an orange solution. After $10 \mathrm{~min}$, pyridine $(7.0 \mathrm{~mL}, 90 \mathrm{mmol}, 1.1$ equiv) was added via syringe. After $15 \mathrm{~min}$, the reaction mixture was transferred in a one-neck $1 \mathrm{~L}$ flask and reduced under vacuum until a solid was obtained. The solid was dissolved in $\mathrm{CH}_{2} \mathrm{Cl}_{2}(200 \mathrm{~mL})$ and

\footnotetext{
${ }^{2}$ C. J. Helal, P. A. Magriotis, E. J. Corey, J. Am. Chem. Soc. 1996, 118, 10938-10939.

3 J. P. Brand, J. Waser, Angew. Chem. Int. Ed. 2010, 49, 7304-7307.
} 
transferred in a 1L separatory funnel. The organic layer was added and washed with $1 \mathrm{M} \mathrm{HCl}$ (200 mL) and the aqueous layer was extracted with $\mathrm{CH}_{2} \mathrm{Cl}_{2}(200 \mathrm{~mL})$. The organic layers were combined, washed with a saturated solution of $\mathrm{NaHCO}_{3}(2 \times 200 \mathrm{~mL})$, dried over $\mathrm{MgSO}_{4}$, filtered and the solvent was evaporated under reduced pressure. Recrystallization from acetonitrile (ca $120 \mathrm{~mL}$ ) afforded $\mathbf{6 a}(30.1 \mathrm{~g}, 70.2 \mathrm{mmol}, 86 \%)$ as colorless crystals. Mp (Dec.): 170-176 ${ }^{\circ} \mathrm{C} ;{ }^{1} \mathrm{H}$ NMR (400 MHz, $\mathrm{CDCl}_{3}$ ): $\delta 8.44(\mathrm{~m}, 1 \mathrm{H}, \mathrm{Ar} H$ ), $8.29(\mathrm{~m}, 1 \mathrm{H}, \mathrm{Ar} H), 7.77$ (m, $2 \mathrm{H}, \mathrm{Ar} H), 1.16$ (m, 21H, TIPS); ${ }^{13} \mathrm{C}$ NMR (100 MHz, $\left.\mathrm{CDCl}_{3}\right): \delta$ 166.4, 134.6, 132.3, 131.4, 131.4, 126.1, 115.6, 114.1, 64.6, 18.4, 11.1; IR v 2943 (m), 2865 (m), 1716 (m), 1618 (m), 1604 (s), 1584 (m), 1557 (m), 1465 (m), 1439 (w), 1349 (m), 1291 (m), 1270 (w), 1244 (m), 1140 (m), $1016(\mathrm{~m}), 999(\mathrm{~m}), 883(\mathrm{~m}), 833(\mathrm{~m}), 742(\mathrm{~m}), 702$ (s), $636(\mathrm{~m})$. The values of the NMR spectra are in accordance with reported literature data. ${ }^{3}$

\section{1-[Phenylethynyl]-1,2-benziodoxol-3(1H)-one (6k)}

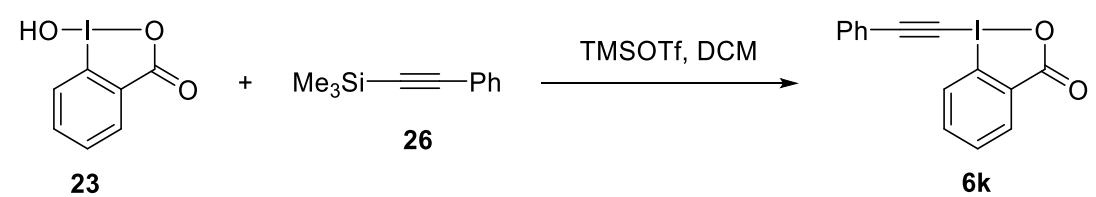

Following a reported procedure, ${ }^{4}$ trimethylsilyl triflate $(7.50 \mathrm{~mL}, 41.5 \mathrm{mmol}, 1.10$ equiv) was added to a suspension of 2-iodosylbenzoic acid (23) (10.0 g, $37.7 \mathrm{mmol}, 1.00$ equiv) in $\mathrm{CH}_{2} \mathrm{Cl}_{2}$ $(100 \mathrm{~mL})$ at room temperature. The resulting yellow mixture was stirred for $1 \mathrm{~h}$, followed by the dropwise addition of trimethyl(phenylethynyl)silane (26) $(8.10 \mathrm{~mL}, 41.5 \mathrm{mmol}, 1.10$ equiv) (slightly exothermic). The resulting suspension was stirred for $6 \mathrm{~h}$ at room temperature, during this time a white solid was formed. A saturated solution of $\mathrm{NaHCO}_{3}(100 \mathrm{~mL})$ was then added and the mixture was stirred vigorously. The resulting suspension was filtered on a glass filter of porosity 4. The two layers of the mother liquors were separated and the organic layer was washed with saturated solution of $\mathrm{NaHCO}_{3}(100 \mathrm{~mL})$, dried over $\mathrm{MgSO}_{4}$, filtered and evaporated under reduced pressure. The resulting mixture was combined with the solid obtained by filtration and boiled in $\mathrm{CH}_{3} \mathrm{CN}$ ( $c a 300 \mathrm{~mL}$ ). The mixture was cooled down, filtered and dried under high vacuum to afford $\mathbf{6 k}(6.08 \mathrm{~g}, 17.4 \mathrm{mmol}, 46 \%)$ as a white solid. Mp (Dec.); 155-160 ${ }^{\circ} \mathrm{C}$ (lit $\left.153-155^{\circ} \mathrm{C}\right) ;{ }^{1} \mathrm{H}$ NMR $\left(400 \mathrm{MHz}, \mathrm{CDCl}_{3}\right) ; \delta 8.46(\mathrm{~m}, 1 \mathrm{H}, \mathrm{ArH}), 8.28(\mathrm{~m}, 1 \mathrm{H}$,

\footnotetext{
${ }^{4}$ J. P. Brand, C. Chevalley, R. Scopelliti, J. Waser, Chem. - Eur. J. 2012, 18, 5655-5666.
} 
$\operatorname{ArH}), 7.80(\mathrm{~m}, 2 \mathrm{H}, \mathrm{ArH}), 7.63$ (m, 2H, $\mathrm{ArH}), 7.48$ (m, 3H, $\mathrm{ArH}) ;{ }^{13} \mathrm{C} \mathrm{NMR}\left(100 \mathrm{MHz}, \mathrm{CDCl}_{3}\right)$ : $\delta 163.9,134.9,132.9,132.5,131.6,131.3 .130 .8,128.8,126.2,120.5,116.2,106.6,50.2$. The characterization data corresponded to the reported values. ${ }^{4}$

\section{1-(p-Tolylethynyl)-1,2-benziodoxol-3(1H)-one (6I)}<smiles>O=C1OI(O)c2ccccc21</smiles>

23

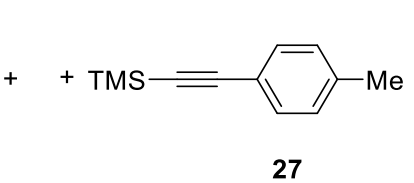

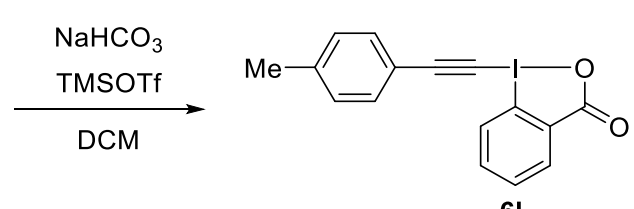

6I

Following a reported procedure, ${ }^{5}$ trimethylsilyl triflate $(1.0 \mathrm{~mL}, 5.5 \mathrm{mmol}, 1.1$ equiv $)$ was added to a suspension of 2-iodosylbenzoic acid (23) (1.32 g, $5.00 \mathrm{mmol}, 1.00$ equiv) in $\mathrm{CH}_{2} \mathrm{Cl}_{2}$ $(15 \mathrm{~mL})$ at room temperature. The resulting suspension was stirred for $3 \mathrm{~h}$, followed by the drop wise addition of trimethyl(p-tolylethynyl)silane (27) (1.04 g, $5.50 \mathrm{mmol}, 1.10$ equiv). The resulting suspension was stirred for $6 \mathrm{~h}$ at room temperature. A saturated solution of $\mathrm{NaHCO}_{3}$ $(20 \mathrm{~mL})$ was then added and the mixture was stirred vigorously for 30 minutes, the two layers were separated and the organic layer was washed with saturated solution of $\mathrm{NaHCO}_{3}(20 \mathrm{~mL})$, dried over $\mathrm{MgSO}_{4}$, filtered and evaporated under reduced pressure. The resulting solid was boiled in $\mathrm{CH}_{3} \mathrm{CN}$ ( $c$ a $20 \mathrm{~mL}$ ). The mixture was cooled down, filtered and dried under high vacuum to afford $6 \mathbf{1}(0.540 \mathrm{~g}, 1.49 \mathrm{mmol}, 30 \%)$ as a white solid. ${ }^{1} \mathrm{H} \mathrm{NMR}\left(400 \mathrm{MHz}, \mathrm{CDCl}_{3}\right)$ : $\delta 8.43(\mathrm{dd}, J=6.1,2.9 \mathrm{~Hz}, 1 \mathrm{H}, \operatorname{Ar} H), 8.30-8.14$ (m, 1H, $\operatorname{Ar} H), 7.77$ (dd, $J=6.9,3.1 \mathrm{~Hz}, 2 \mathrm{H}$, $\operatorname{ArH}), 7.50(\mathrm{~d}, J=7.8 \mathrm{~Hz}, 2 \mathrm{H}, \mathrm{ArH}), 7.25(\mathrm{~d}, J=7.6 \mathrm{~Hz}, 2 \mathrm{H}, \mathrm{ArH}), 2.43$ (s, 3H, $\left.\mathrm{ArCH}_{3}\right) ;{ }^{13} \mathrm{C}$ NMR (100 MHz, $\left.\mathrm{CDCl}_{3}\right): \delta 166.6,141.5,134.9,132.8,132.5,131.6,131.3,129.5,126.2,117.4$, 116.2, 107.25, 49.1, 21.7. The characterization data corresponded to the reported values. ${ }^{5}$

\section{1-[2-Bromophenylethynyl]-1,2-benziodoxol-3(1H)-one (6m)}

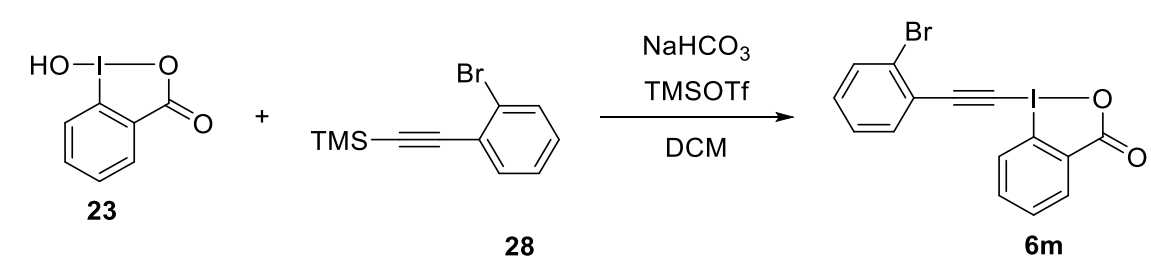

\footnotetext{
${ }^{5}$ H. Huang, G. Zhang, L. Gong, S. Zhang, Y. Chen, J. Am. Chem. Soc. 2014, 136, 2280-2283.
} 
Following a reported procedure, ${ }^{6}$ trimethylsilyl triflate $(1.0 \mathrm{~mL}, 5.5 \mathrm{mmol}, 1.1$ equiv $)$ was added to a suspension of 2-iodosylbenzoic acid (23) (1.32 g, $5.00 \mathrm{mmol}, 1.00$ equiv) in $\mathrm{CH}_{2} \mathrm{Cl}_{2}$ $(15 \mathrm{~mL})$ at room temperature. The resulting suspension was stirred for $3 \mathrm{~h}$, followed by the drop wise addition of ((2-bromophenyl)ethynyl)trimethylsilane (28) (1.17 g, $5.50 \mathrm{mmol}, 1.10$ equiv). The resulting suspension was stirred for $6 \mathrm{~h}$ at room temperature. A saturated solution of $\mathrm{NaHCO}_{3}(20 \mathrm{~mL})$ was then added and the mixture was stirred vigorously for 30 minutes, the two layers were separated and the organic layer was washed with saturated solution of $\mathrm{NaHCO}_{3}$ (20 mL), dried over $\mathrm{MgSO}_{4}$, filtered and evaporated under reduced pressure. The resulting solid was boiled in $\mathrm{CH}_{3} \mathrm{CN}$ (ca $20 \mathrm{~mL}$ ). The mixture was cooled down, filtered and dried under high vacuum to afford $6 \mathrm{~m}(1.50 \mathrm{~g}, 3.51 \mathrm{mmol}, 70 \%)$ as a white solid. $\mathrm{Mp}$ (Dec.): 174-177 ${ }^{\circ} \mathrm{C} ; 1 \mathrm{H}$ NMR (400 MHz, CDCl3): $\delta 8.44(\mathrm{td}, J=7.3,2.1 \mathrm{~Hz}, 2 \mathrm{H}, \mathrm{ArH}), 7.84-7.74$ (m, 2H, ArH), 7.68 (d, $J=1.1 \mathrm{~Hz}, 1 \mathrm{H}, \mathrm{ArH}), 7.61(\mathrm{dd}, J=7.6,1.7 \mathrm{~Hz}, 1 \mathrm{H}, \mathrm{ArH}), 7.36(\mathrm{dtd}, J=22.4,7.5,1.5 \mathrm{~Hz}$, $2 \mathrm{H}, \mathrm{Ar} H) ;{ }^{13} \mathrm{C} \mathrm{NMR}\left(100 \mathrm{MHz}, \mathrm{CDCl}_{3}\right): \delta 166.6,135.2,134.7,133.0,132.7,131.8,131.3$, 127.6, 126.8, 126.4, 123.2, 116.5, 104.3, 55.4; IR v 2358 (w), 2155 (w), 1638 (s), $1616(\mathrm{~m})$, $1585(w), 1466(w), 1316(\mathrm{~m}), 1147(w)$. The characterization data corresponded to the reported values. ${ }^{6}$

\section{1-[3,3-Dimethylbutynyl]-1,2-benziodoxol-3(1H)-one (6n)}

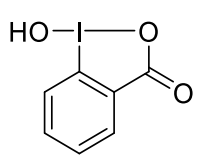

23

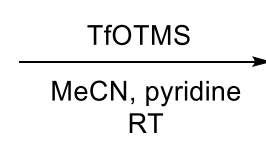

29

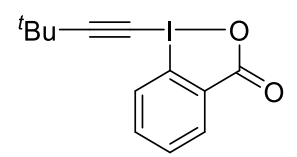

$6 n$

Following a reported procedure, ${ }^{7}$ trimethylsilyltriflate $(1.52 \mathrm{~mL}, 8.42 \mathrm{mmol}, 1.0$ equiv) was added dropwise to a stirred solution of 2-iodosylbenzoic acid (23) (2.69 g, $10.1 \mathrm{mmol}, 1.2$ equiv) in acetonitrile (30 mL). 3,3-dimethylbut-1-yn-1-yl)trimethylsilane (29) (1.30 g, 8.42 mmol, 1.0 equiv) was then added dropwise, followed, after $15 \mathrm{~min}$, by the addition of pyridine ( $680 \mu \mathrm{L}, 8.42 \mathrm{mmol}, 1.0$ equiv). The mixture was stirred $10 \mathrm{~min}$. The solvent was then removed under reduced pressure. $\mathrm{CH}_{2} \mathrm{Cl}_{2}$ and $1 \mathrm{M} \mathrm{NaOH}$ were added. The resulting suspension was filtered. The layers were separated and the aqueous layer was extracted with $\mathrm{CH}_{2} \mathrm{Cl}_{2}$. The

\footnotetext{
${ }^{6}$ F. Le Vaillant, T. Courant, J. Waser, Angew. Chem. Int. Ed. 2015, 54, 11200-11204.

${ }^{7}$ C. C. Chen, J. Waser, Org. Lett. 2015, 17, 736-739.
} 
organic layers were combined, dried over $\mathrm{MgSO}_{4}$, filtered and the solvent was evaporated under reduced pressure. The resulting solid was boiled in $\mathrm{CH}_{3} \mathrm{CN}$ (ca $20 \mathrm{~mL}$ ). The mixture was cooled down, filtered and dried under high vacuum to afford $\mathbf{6 n}(1.43 \mathrm{~g}, 4.36 \mathrm{mmol}, 57 \%)$ as a colorless solid." Mp (Dec.) $189-192^{\circ} \mathrm{C} .{ }^{1} \mathrm{H}-\mathrm{NMR}\left(400 \mathrm{MHz}, \mathrm{CDCl}_{3}\right) \delta 8.39$ (m, 1H, Ar-H), 8.12 (m, $1 \mathrm{H}, \operatorname{Ar}-H), 7.75(\mathrm{~m}, 2 \mathrm{H}, \mathrm{Ar}-H), 1.37\left(\mathrm{~s}, 9 \mathrm{H},{ }^{t} \mathrm{Bu}\right)$. The characterization data corresponded to the reported values. ${ }^{7}$

\section{2-Cyclopropylethynyl-1,2-benziodoxol-3(1H)-one (6o)}

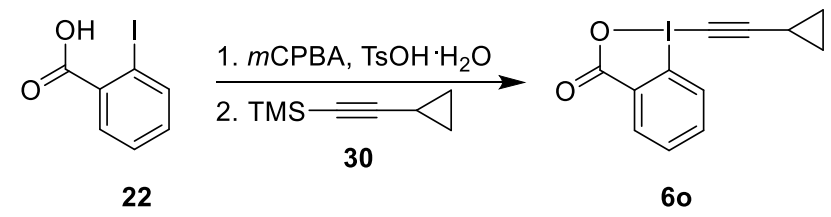

Following a reported procedure, ${ }^{8}$ 2-iodobenzoic acid (22) (6.41 g, $25.8 \mathrm{mmol}, 1.00$ equiv), para-toluenesulfonic acid monohydrate $\left(\mathrm{TsOH}^{\mathrm{H}} \mathrm{H}_{2} \mathrm{O}, 4.91 \mathrm{~g}, 25.8 \mathrm{mmol}, 1.00\right.$ equiv) and metachloroperoxybenzoic acid (mCPBA-70\%, $7.00 \mathrm{~g}, 28.4 \mathrm{mmol}, 1.10$ equiv) were dissolved in dichloromethane $(48 \mathrm{~mL})$ and 2,2,2-trifluoroethanol $(48 \mathrm{~mL})$. The mixture was stirred at room temperature under nitrogen for $1 \mathrm{~h}$, after which (cyclopropylethynyl)trimethylsilane (30) (5.00 $\mathrm{g}, 36.2 \mathrm{mmol}, 1.40$ equiv) was added in one portion. The reaction mixture was stirred for $12 \mathrm{~h}$ at room temperature, filtered and concentrated in vacuo. The resulting oil was dissolved in $\mathrm{CH}_{2} \mathrm{Cl}_{2}$ (400 mL) and under vigorous stirring, a saturated solution of $\mathrm{NaHCO}_{3}(400 \mathrm{~mL})$ was added. The mixture was stirred for $1 \mathrm{~h}$, the two layers were separated and the aqueous layer was extracted with additional portions of $\mathrm{CH}_{2} \mathrm{Cl}_{2}$ (3 x $\left.100 \mathrm{~mL}\right)$. The combined organic layers were dried over $\mathrm{MgSO}_{4}$, filtered and concentrated in vacuo. The crude product was purified by flash column chromatography using ethyl acetate to afford $\mathbf{6 0}(2.11 \mathrm{~g}, 6.76 \mathrm{mmol}, 26 \%)$ as a white solid. Mp (Dec.): $174.2-177.6{ }^{\circ} \mathrm{C}$; TLC (EtOAc:MeOH, 9:1 v/v): $\mathrm{R}_{\mathrm{f}}=0.46, \mathrm{KMnO}_{4} ;{ }^{1} \mathrm{H}$ NMR $\left(\mathrm{CDCl}_{3}, 400 \mathrm{MHz}\right): \delta 8.34(\mathrm{dd}, J=7.0,2.1 \mathrm{~Hz}, 1 \mathrm{H}, \mathrm{ArH}), 8.18-8.09$ (m, 1H, $\mathrm{ArH}$ ), 7.81-7.63 $(\mathrm{m}, 2 \mathrm{H}, \mathrm{ArH}), 1.59$ (tt, $J=8.2,5.0 \mathrm{~Hz}, 1 \mathrm{H}, \mathrm{CH}), 1.07-0.85\left(\mathrm{~m}, 4 \mathrm{H}, \mathrm{CH}_{2} \mathrm{CH}_{2}\right) ;{ }^{13} \mathrm{C} \mathrm{NMR}\left(\mathrm{CDCl}_{3}\right.$, $100 \mathrm{MHz}): \delta 166.7,134.7,132.3,131.7,131.4,126.2,115.9,113.3,35.0,9.8,1.1$; IR v 3464 (w), 3077 (w), 3012 (w), 2238 (w), 2159 (m), 1607 (s), 1559 (m), 1438 (m), 1338 (m), 1298

${ }^{8}$ D. P. Hari, J. Waser, J. Am. Chem. Soc. 2016, 138, 2190-2193. 
(m), 833 (m), $744(\mathrm{~s}), 691$ (m). HRMS (ESI) calcd. for $\mathrm{C}_{12} \mathrm{H}_{10} \mathrm{IO}_{2}{ }^{+}[\mathrm{M}+\mathrm{H}]^{+}$312.9720; found 312.9719. The characterization data corresponded to the reported values. ${ }^{8}$

(5-Chloropent-1-ynyl)-1,2-benziodoxol-3(1H)-one (6p)

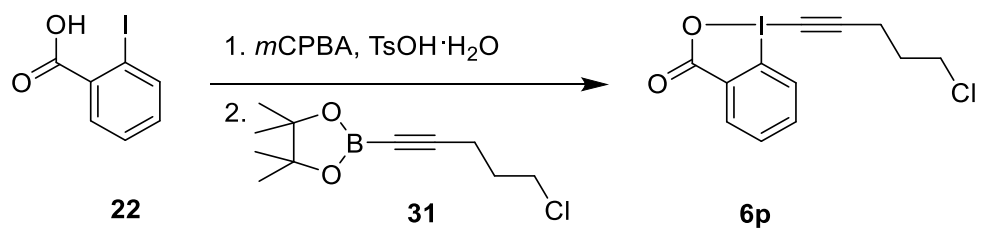

Following a reported procedure, ${ }^{9}$ 2-iodobenzoic acid (22) (3.76 g, $15.2 \mathrm{mmol}, 1.00$ equiv), para-toluenesulfonic acid monohydrate (TsOH. $\mathrm{H}_{2} \mathrm{O}, 2.88 \mathrm{~g}, 15.2 \mathrm{mmol}, 1.00$ equiv) and metachloroperoxybenzoic acid (mCPBA-70\%, $4.11 \mathrm{~g}, 16.7 \mathrm{mmol}, 1.10$ equiv) were dissolved in $\mathrm{CH}_{2} \mathrm{Cl}_{2}(30 \mathrm{~mL})$ and 2,2,2-trifluoroethanol $(30 \mathrm{~mL})$. The mixture was stirred at room temperature under nitrogen for $1 \mathrm{~h}$, after which 5-chloro-1-pentynyl-1-boronic acid pinacol ester (31) (4.85 g, $21.2 \mathrm{mmol}, 1.40$ equiv) was added in one portion. The reaction mixture was stirred for 90 minutes at room temperature, filtered and concentrated in vacuo. The resulting oil was dissolved in $\mathrm{CH}_{2} \mathrm{Cl}_{2}(15 \mathrm{~mL})$ and under vigorous stirring, saturated solution of $\mathrm{NaHCO}_{3}$ $(15 \mathrm{~mL})$ was added. The mixture was stirred for 10 minutes, the two layers were separated and the aqueous layer was extracted with additional portions of $\mathrm{CH}_{2} \mathrm{Cl}_{2}(3 \times 15 \mathrm{~mL})$. The combined organic layers were dried over $\mathrm{MgSO}_{4}$, filtered and concentrated in vacuo. The crude product was purified by flash column chromatography using ethyl acetate to afford $\mathbf{6 p}$ (3.76 g, 10.8 mmol, 71\%) as a white solid. TLC (EtOAc): $\mathrm{R}_{\mathrm{f}}=0.15, \mathrm{KMnO}_{4} ; \mathrm{Mp}: 138.5-141.7{ }^{\circ} \mathrm{C} ;{ }^{1} \mathrm{H} \mathrm{NMR}$ $\left(\mathrm{CDCl}_{3}, 400 \mathrm{MHz}\right): \delta$ 8.41-8.34 (m, 1H, $\left.\operatorname{ArH}\right), 8.22-8.13(\mathrm{~m}, 1 \mathrm{H}, \operatorname{Ar} H), 7.82-7.68(\mathrm{~m}, 2 \mathrm{H}$, $\operatorname{ArH}), 3.71\left(\mathrm{t}, J=6.1 \mathrm{~Hz}, 2 \mathrm{H}, \mathrm{ClCH}_{2} \mathrm{CH}_{2}\right), 2.82\left(\mathrm{t}, J=6.9 \mathrm{~Hz}, 2 \mathrm{H}, \mathrm{CCCH}_{2} \mathrm{CH}_{2}\right), 2.18-2.05(\mathrm{~m}$,

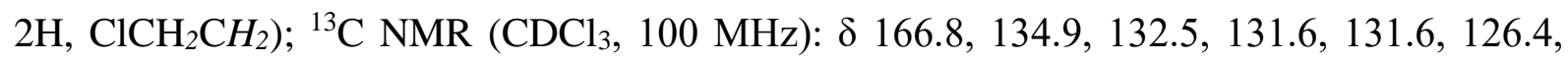
115.8, 107.1, 43.4, 41.2, 30.7, 18.0; IR v 2942 (w), 2866 (w), 2171 (w), 2091 (w), 1727 (w), 1617 (s), 1556 (w), 1441 (w), 1339 (m), 1213 (w), 1023 (w), 846 (w), 742 (s). The characterization data corresponded to the reported values. ${ }^{9}$

\section{4,5-Dimethoxy-2-iodosylbenzoic acid (33)}

\footnotetext{
${ }^{9}$ R. Frei, M. D. Wodrich, D. P. Hari, P. A. Borin, C. Chauvier, J. Waser, J. Am. Chem. Soc. 2014, 136, 16563-16573.
} 
<smiles>COc1cc(I)c(C(=O)O)cc1OC</smiles>

32

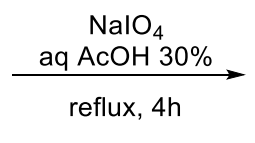

reflux, $4 \mathrm{~h}$

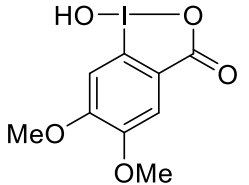

33

Following a reported procedure, ${ }^{4} \mathrm{NaIO}_{4}(1.25 \mathrm{~g}, 5.84 \mathrm{mmol}, 1.05$ equiv) and 2-iodo-4,5dimethoxybenzoic acid (32) (1.71 g, 5.56 mmol, 1.00 equiv) were suspended in 30\% (v:v) aq. AcOH $(15 \mathrm{~mL})$. The mixture was vigorously stirred and refluxed for $4 \mathrm{~h}$. The reaction mixture was then diluted with cold water $(40 \mathrm{~mL})$ and allowed to cool to RT, protecting it from light. The crude product was collected by filtration, washed on the filter with ice water $(3 \mathrm{x} 4 \mathrm{~mL})$ and acetone $(3 \mathrm{x} 4 \mathrm{~mL})$, and air-dried in the dark to give the pure product 33 (1.64 g, $5.06 \mathrm{mmol}$, 91\%) as a colorless solid. ${ }^{1} \mathrm{H}$ NMR (400 MHz, DMSO); $\delta 7.45$ (s, 1H, ArH), 7.23 (s, 1H, ArH), $3.88(\mathrm{~d}, 6 \mathrm{H}, J=0.9 \mathrm{~Hz}, \mathrm{Me})$. The characterization data corresponded to the reported values. ${ }^{4}$

\section{4,5-Dimethoxy-1-[(triisopropylsilyl)ethynyl]-1,2-benziodoxol-3(1H)-one $(6 q)$}<smiles>COc1cc2c(cc1OC)I(O)OC2=O</smiles>

33

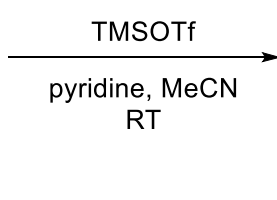

ine, $\mathrm{MeCN}$

25

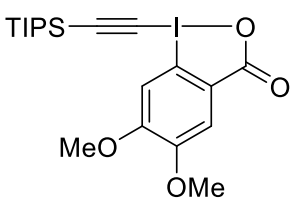

6q

Following a reported procedure, ${ }^{4}$ trimethylsilyltriflate $(400 \mu \mathrm{L}, 2.20 \mathrm{mmol}, 1.1$ equiv, freshly distilled) was added dropwise to a stirred solution of $\mathbf{3 3}$ (648 mg, $2.00 \mathrm{mmol}, 1.0$ equiv) in acetonitrile (10 mL). After $2 \mathrm{~min}$, (trimethylsilyl)(triiso-propylsilyl)acetylene (25) (560 mg, $2.20 \mathrm{mmol}, 1.1$ equiv) was added dropwise, followed, after $20 \mathrm{~min}$, by the addition of pyridine ( $180 \mu \mathrm{L}, 2.20 \mathrm{mmol}, 1.1$ equiv). The mixture was stirred $20 \mathrm{~min}$. The solvent was then removed under reduced pressure and the yellow crude oil was dissolved in dichloromethane $(20 \mathrm{~mL})$. The organic layer was washed with $1 \mathrm{M} \mathrm{HCl}(20 \mathrm{~mL})$ and the aqueous layer was extracted with $\mathrm{CH}_{2} \mathrm{Cl}_{2}(20 \mathrm{~mL})$. The organic layers were combined, washed with a saturated solution of $\mathrm{NaHCO}_{3}(40 \mathrm{~mL})$, dried over $\mathrm{MgSO}_{4}$, filtered and the solvent was evaporated under reduced pressure. Recrystallization from acetonitrile (ca $8 \mathrm{~mL}$ ) and wash with hexanes afforded $\mathbf{6 q}$ (575 mg, $1.18 \mathrm{mmol}, 59 \%$ ) as colorless cristals. Mp (Dec.) $180.0-183.0{ }^{\circ} \mathrm{C} ;{ }^{1} \mathrm{H} \mathrm{NMR}(400 \mathrm{MHz}$, $\left.\mathrm{CDCl}_{3}\right) ; \delta 7.83(\mathrm{~s}, 1 \mathrm{H}, \mathrm{ArH}), 7.61$ (s, 1H, $\left.\mathrm{ArH}\right), 3.99$ (s, 3H, OMe), 3.97 (s, 3H, OMe), 1.14 
(m, 21H, TIPS); ${ }^{13} \mathrm{C}$ NMR (100 MHz, $\left.\mathrm{CDCl}_{3}\right) ; \delta 166.7,154.9,152.2,124.5,113.8,113.2$, 107.8, 104.7, 66.0, 56.7, 56.5, 18.5, 11.2; IR 2945 (w), 1616 (m), 1569 (w), 1497 (m), 1464 (w), 1396 (m), 1317 (w), 1269 (m), 1215 (m), 1181 (w), 1129 (w), 1026 (w), 921 (w), $884(w)$, $778(\mathrm{w}), 734(\mathrm{~m}), 708(\mathrm{~m}), 639$ (s). The characterization data corresponded to the reported values. $^{4}$

2-Iodosyl-5-nitrobenzoic acid (34) and 2-iodosyl-3-nitrobenzoic acid (35)<smiles>O=C(O)c1ccccc1I</smiles>

22

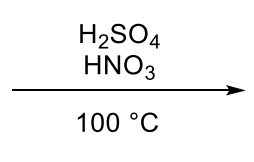

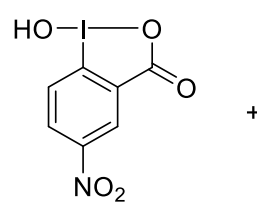

34<smiles>O=C1OI(O)c2c1cccc2[N+](=O)[O-]</smiles>

35

Following a reported procedure, ${ }^{4}$ fuming nitric acid $(3.3 \mathrm{~mL})$ was added to 2 -iodobenzoic acid (22) (5.0 g, 20 mmol, 1.0 equiv) in concentrated $\mathrm{H}_{2} \mathrm{SO}_{4}(6.7 \mathrm{~mL})$. The reaction was equipped with a cooler and a nitrous vapor trap and was heated at $100{ }^{\circ} \mathrm{C}$ for $1 \mathrm{~h}$. The reaction mixture was then poured in ice-water and filtered. The resulting solid was refluxed in water $(50 \mathrm{~mL})$ and filtered. A second crop of precipitate was filtered from the mother liquors. Both solids were combined, washed with acetone $(10 \mathrm{~mL})$ and dried under vacuum to afford 34 (2.19 g, 7.10 mmol, $36 \%$ ). The mother liquors were reduced to one third and then kept at $4{ }^{\circ} \mathrm{C}$, the resulting precipitate was filtered, washed with acetone $(10 \mathrm{~mL})$ and dried under vacuum to afford 35 (630 mg, $2.04 \mathrm{mmol}, 10 \%$ ). 34: ${ }^{1} \mathrm{H}$ NMR (400 MHz, $\left(\mathrm{CD}_{3}\right)_{2} \mathrm{SO}$ ): $\delta 8.73$ (dd, $J=8.8,2.6 \mathrm{~Hz}$, $1 \mathrm{H}, \operatorname{Ar} H), 8.58(\mathrm{~d}, J=2.4 \mathrm{~Hz}, 1 \mathrm{H}, \mathrm{Ar} H), 8.54$ (br s, $1 \mathrm{H}, \mathrm{OH}), 8.11$ (d, $J=8.8 \mathrm{~Hz}, 1 \mathrm{H}, \operatorname{Ar} H)$. 35: ${ }^{1} \mathrm{H}$ NMR (400 MHz, $\left.\left(\mathrm{CD}_{3}\right)_{2} \mathrm{SO}\right): \delta 7.92(\mathrm{dd}, J=7.9,1.5 \mathrm{~Hz}, 1 \mathrm{H}, \mathrm{Ar} H), 7.79(\mathrm{~m}, 1 \mathrm{H}, \mathrm{Ar} H)$, $7.67(\mathrm{~m}, 1 \mathrm{H}, \mathrm{Ar} H)$. The characterization data corresponded to the reported values. ${ }^{4}$

\section{5-Nitro-1-[(triisopropylsilyl)ethynyl]-1,2-benziodoxol-3(1H)-one $(6 r)$}
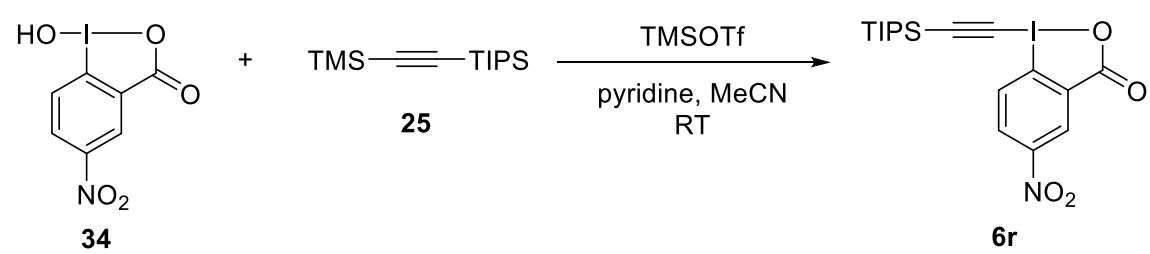

Following a reported procedure ${ }^{4}$ trimethylsilyltriflate $(646 \mu \mathrm{L}, 3.56 \mathrm{mmol}, 1.10$ equiv, freshly distilled over $\mathrm{CaH}_{2}$ ) was added dropwise to a stirred solution of 2-iodosyl-5-nitrobenzoic acid 
$34\left(1.00 \mathrm{~g}, 3.23 \mathrm{mmol}, 1.00\right.$ equiv) in acetonitrile $(15 \mathrm{~mL})$ at $0{ }^{\circ} \mathrm{C}$. After $15 \mathrm{~min}$ at room temperature, (trimethylsilyl)(triiso-propylsilyl)acetylene (25) (906 mg, 3.56 mmol, 1.10 equiv) was added dropwise, followed, after $30 \mathrm{~min}$, by the addition of pyridine $(290 \mu \mathrm{L}, 3.56 \mathrm{mmol}$, 1.10 equiv). The mixture was stirred for $20 \mathrm{~min}$. The solvent was then removed under reduced pressure and the yellow crude oil was dissolved in $\mathrm{CH}_{2} \mathrm{Cl}_{2}(25 \mathrm{~mL})$. The organic layer was washed with $1 \mathrm{M} \mathrm{HCl}(25 \mathrm{~mL})$ and the aqueous layer was extracted with $\mathrm{CH}_{2} \mathrm{Cl}_{2}(25 \mathrm{~mL})$. The organic layers were combined, washed with a saturated solution of $\mathrm{NaHCO}_{3}(20 \mathrm{~mL})$, dried over $\mathrm{MgSO}_{4}$, filtered and the solvent was evaporated under reduced pressure. Recrystallization from acetonitrile ( $\mathrm{ca} 20 \mathrm{~mL}$ ) afforded $6 \mathbf{r}$ (960 mg, $2.02 \mathrm{mmol}, 63 \%$ ) as a white solid. Mp (Dec.); 198.0-206.0 ${ }^{\circ} \mathrm{C} ;{ }^{1} \mathrm{H}$ NMR (400 MHz, $\left.\mathrm{CDCl}_{3}\right): \delta 9.20(\mathrm{~d}, J=2.6 \mathrm{~Hz}, 1 \mathrm{H}, \mathrm{Ar} H$ ), 8.60 (ddd, $J=$ 9.0, 2.5, 0.4 Hz, 1H, ArH), 8.53 (d, $J=8.9 \mathrm{~Hz}, 1 \mathrm{H}, \operatorname{Ar} H), 1.30-1.14$ (m, 21H, TIPS); ${ }^{13} \mathrm{C}$ NMR $\left(100 \mathrm{MHz} \mathrm{CDCl}_{3}\right): \delta 166.4,150.7,134.4,129.0,128.2,126.5,122.7,115.2,63.1,18.5,11.3$. The characterization data corresponded to the reported values. ${ }^{4}$

\section{1-Hydroxy-1,2-naphthiodoxol-3-(1H) (37)}

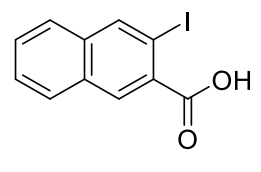

36

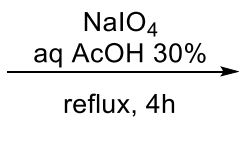

reflux, $4 \mathrm{~h}$

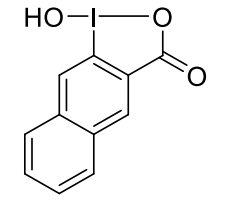

37

Following a reported procedure, ${ }^{10} \mathrm{NaIO}_{4}(1.9 \mathrm{~g}, 8.8 \mathrm{mmol}, 1.05$ equiv) and 3-iodo-2-naphthoic acid (36) (2.5 g, $8.4 \mathrm{mmol}, 1.00$ equiv) were suspended in 30\% (v:v) aq. AcOH (27 mL). The mixture was vigorously stirred and refluxed for $4 \mathrm{~h}$. The reaction mixture was then diluted with cold water $(180 \mathrm{~mL})$ and allowed to cool to $\mathrm{rt}$, protecting it from light. After $1 \mathrm{~h}$, the crude product was collected by filtration, washed on the filter with ice water $(3 \times 8 \mathrm{~mL})$ and acetone $(3 \times 8 \mathrm{~mL})$, and air-dried in the dark to give the pure product $37(2.2 \mathrm{~g}, 6.9 \mathrm{mmol}, 82 \%)$ as a colorless solid. ${ }^{1} \mathrm{H}$ NMR (400 MHz, DMSO): $\delta 8.67$ (s, $\left.1 \mathrm{H}, \mathrm{OH}\right), 8.38$ (s, 1H, ArH), 8.28 (d, $J$ $=8.0 \mathrm{~Hz}, 1 \mathrm{H}, \operatorname{Ar} H), 8.18-8.20(\mathrm{~m}, 2 \mathrm{H}, \operatorname{Ar} H), 7.71-7.78(\mathrm{~m}, 2 \mathrm{H}, \operatorname{Ar} H) .{ }^{13} \mathrm{C} \mathrm{NMR}(100 \mathrm{MHz}$, $\left.\mathrm{CDCl}_{3}\right): \delta 168.5,136.6,133.5,132.5,130.0,129.6,128.8,128.7,128.6,127.1,116.6$. The characterization data corresponded to the reported values. ${ }^{10}$

\footnotetext{
${ }^{10}$ N. Declas, F. Le Vaillant, J. Waser, Org. Lett. 2019, 21, 524-528.
} 


\section{1-((Triisopropylsilyl)ethynyl)-1,2-naphthiodoxol-3-(1H) (6s)}<smiles>O=C1OI(O)c2cc3ccccc3cc21</smiles>

37

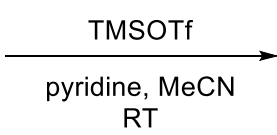

25

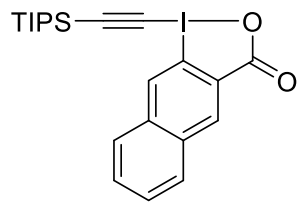

6s

Trimethylsilyltriflate ( $254 \mu \mathrm{L}, 1.40 \mathrm{mmol}, 1.10$ equiv) was added dropwise to a stirred solution of 1-hydroxy-1,2-naphthiodoxol-3-(1H) 37 (400 mg, $1.28 \mathrm{mmol}, 1.00$ equiv) in acetonitrile (6.4 $\mathrm{mL}$ ) at $0{ }^{\circ} \mathrm{C}$. After $15 \mathrm{~min}$ at room temperature, (trimethylsilyl)(triiso-propylsilyl)acetylene (25) ( $357 \mathrm{mg}, 1.40 \mathrm{mmol}, 1.10$ equiv) was added dropwise, followed, after $30 \mathrm{~min}$, by the addition of pyridine (113 $\mu \mathrm{L}, 1.40 \mathrm{mmol}, 1.10$ equiv). The mixture was stirred for $20 \mathrm{~min}$. The solvent was then removed under reduced pressure and the yellow crude oil was dissolved in $\mathrm{CH}_{2} \mathrm{Cl}_{2}$ $(25 \mathrm{~mL})$. The organic layer was washed with $1 \mathrm{M} \mathrm{HCl}(25 \mathrm{~mL})$ and the aqueous layer was extracted with $3 \times 20 \mathrm{~mL}$ of $\mathrm{CH}_{2} \mathrm{Cl}_{2}$. The organic layers were combined, washed successively with a saturated solution of $\mathrm{NaHCO}_{3}(20 \mathrm{~mL})$ and brine $(20 \mathrm{~mL})$, dried over $\mathrm{MgSO}_{4}$, filtered and concentrated in vacuo. The resulting solid was boiled in $\mathrm{CH}_{3} \mathrm{CN}(5 \mathrm{~mL})$. The mixture was filtered, the solid was washed with pentane and collected with $\mathrm{CH}_{2} \mathrm{Cl}_{2}$. The resulting solution was concentrated in vacuo to afford $6 \mathbf{s}$ (466 mg, $0.974 \mathrm{mmol}, 76 \%$ ) as a white solid. Rf 0.25 (Dichloromethane:Methanol 95:5); Mp (Dec.): $>180{ }^{\circ} \mathrm{C} ;{ }^{1} \mathrm{H}$ NMR $(400 \mathrm{MHz}$, Chloroform- $d$ ) $\delta$ 8.95 (s, 1H, ArH), 8.79 (s, 1H, ArH), $8.16-8.09$ (m, 1H, ArH), 7.92 - 7.84 (m, 1H, ArH), 7.75 - 7.68 (m, 2H, ArH), 1.29 - 1.18 (m, 21H, TIPS); ${ }^{13} \mathrm{C}$ NMR (100 MHz, Chloroform- $d$ ) $\delta 166.9$, 137.1, 134.4, 133.3, 129.8, 129.3, 128.8, 127.7, 126.7, 126.7, 114.5, 112.1, 65.4, 18.8, 11.4; HRMS (ESI/QTOF) m/z: $[\mathrm{M}+\mathrm{H}]^{+}$Calcd for $\mathrm{C}_{22} \mathrm{H}_{28} \mathrm{IO}_{2} \mathrm{Si}^{+}$479.0898; Found 479.0900; IR $\left(v_{\max }, \mathrm{cm}^{-1}\right) 2943(\mathrm{~m}), 2865(\mathrm{~m}), 1649(\mathrm{~m}), 1620(\mathrm{~s}), 1610(\mathrm{~s}), 1561(\mathrm{~m}), 1462(\mathrm{~m}), 1440(\mathrm{~m})$, 1337 (m), 1296 (m), 882 (m), 835 (m), 731 (s), 703 (s), 691 (s), 676 (s).

\section{(E)-1-(2-Cyclohexylvinyl)-1,2-benziodoxol-3(1H)-one (6t)}

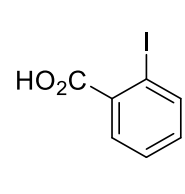

22

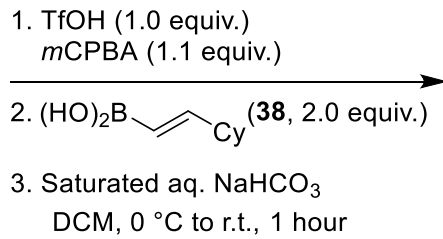
$\mathrm{DCM}, 0^{\circ} \mathrm{C}$ to r.t., 1 hour<smiles></smiles>

$6 t$ 
Following a reported procedure, ${ }^{11}$ trifluoromethanesulfonic acid (TfOH, $0.533 \mathrm{~mL}, 6.00 \mathrm{mmol}$, 1.00 equiv.) was added dropwise to a stirred solution of 2-iodobenzoic acid (22) (1.49 g, 6.00 mmol, 1.00 equiv.) and meta-chloroperoxybenzoic acid ( $m$ CPBA-77\%, $1.48 \mathrm{~g}, 6.60 \mathrm{mmol}, 1.10$ equiv.) in dichloromethane $(37.5 \mathrm{~mL})$ at $0{ }^{\circ} \mathrm{C}$. After 15 minutes stirring at room temperature, (E)-(2-cyclohexylvinyl)boronic acid (38) (1.85 g, $12.0 \mathrm{mmol}, 2.00$ equiv.) was added in one portion at $0{ }^{\circ} \mathrm{C}$. The reaction mixture was stirred for an additional 1 hour at room temperature, then the resulting mixture was concentrated in vacuo. Diethyl ether $(300 \mathrm{~mL})$ was added and the resulting mixture was vigorously stirred over 30 minutes. The solid was filtered off and washed with portions of diethyl ether $(5 \times 50 \mathrm{~mL})$. The resulting solid was dissolved in dichloromethane $(50 \mathrm{~mL})$ and treated with a solution of saturated aqueous sodium bicarbonate $(50 \mathrm{~mL})$. The mixture was vigorously stirred for 1 hour, then the organic layer was diluted with dichloromethane $(100 \mathrm{~mL})$ and the two layers were separated. The aqueous layer was extracted with additional portions of dichloromethane $(3 \times 50 \mathrm{~mL})$ and the combined organic layers were washed with water $(50 \mathrm{~mL})$ and brine $(50 \mathrm{~mL})$, then dried over magnesium sulfate and filtered. The volatiles were removed to afford pure $6 \mathbf{t}(0.654 \mathrm{~g}, 1.84 \mathrm{mmol}, 31 \%$ yield $)$ as a beige solid. $\mathrm{R}_{\mathrm{f}} 0.46$ (Dichloromethane:Methanol 95:5); ${ }^{1} \mathrm{H}$ NMR (400 MHz, $\left.\mathrm{CDCl}_{3}\right) \delta 8.44-8.33(\mathrm{~m}, 1 \mathrm{H}$, $\operatorname{Ar} H), 7.55(\mathrm{tt}, J=7.2,5.3 \mathrm{~Hz}, 2 \mathrm{H}, \mathrm{Ar} H), 7.50-7.39$ (m, 1H, $\mathrm{Ar} H), 6.98(\mathrm{dd}, J=15.4,6.8 \mathrm{~Hz}$, $1 \mathrm{H}, \mathrm{ICHCH}), 6.55(\mathrm{dd}, J=15.3,1.2 \mathrm{~Hz}, 1 \mathrm{H}, \mathrm{ICHCHCH}), 2.45-2.30\left(\mathrm{~m}, 1 \mathrm{H}, \mathrm{CHCH}\left(\mathrm{CH}_{2}\right)_{2}\right)$, $1.96-1.75(\mathrm{~m}, 4 \mathrm{H}, \mathrm{CH}), 1.75-1.65\left(\mathrm{~m}, 1 \mathrm{H}, \mathrm{CH}_{2}\right), 1.45-1.09\left(\mathrm{~m}, 5 \mathrm{H}, \mathrm{CH}_{2}\right)$; ${ }^{13} \mathrm{C} \mathrm{NMR}(101$ $\left.\mathrm{MHz}, \mathrm{CDCl}_{3}\right) \delta 166.7,164.0,133.7,133.4,132.9,130.7,125.8,114.6,98.9,44.6,31.8,25.8$, 25.6. Spectroscopic data was consistent with the values reported in literature. ${ }^{11}$

\section{(E)-1-Styryl-1,2-benziodoxol-3(1H)-one (6u)}

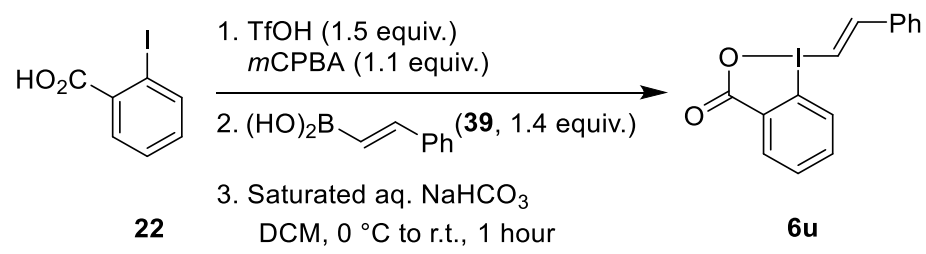

Following a reported procedure, ${ }^{11}$ trifluoromethanesulfonic acid $(\mathrm{TfOH}, 0.666 \mathrm{~mL}, 7.50 \mathrm{mmol}$, 1.50 equiv.) was added dropwise to a stirred solution of 2-iodobenzoic acid (22) (1.24 g, 5.00

\footnotetext{
${ }^{11}$ E. Stridfeldt, A. Seemann, M. J. Bouma, C. Dey, A. Ertan, B. Olofsson, Chem. - Eur. J. 2016, 22, 16066-16070.
} 
mmol, 1.00 equiv.) and meta-chloroperoxybenzoic acid ( $m$ CPBA-77\%, $1.23 \mathrm{~g}, 5.50 \mathrm{mmol}, 1.10$ equiv.) in dichloromethane $(31.3 \mathrm{~mL})$ at $0{ }^{\circ} \mathrm{C}$. After 15 minutes stirring at room temperature, (E)-styrylboronic acid (39) (1.04 g, $7.00 \mathrm{mmol}, 1.40$ equiv.) was added in one portion at $0{ }^{\circ} \mathrm{C}$. The reaction mixture was stirred for an additional 1 hour at room temperature, then the resulting mixture was treated with a solution of saturated aqueous sodium bicarbonate $(50 \mathrm{~mL})$. The mixture was vigorously stirred for 1 hour, then the organic layer was diluted with dichloromethane $(100 \mathrm{~mL})$ and the two layers were separated. The aqueous layer was extracted with additional portions of dichloromethane $(3 \times 50 \mathrm{~mL})$ and the combined organic layers were washed with water $(50 \mathrm{~mL})$ and brine $(50 \mathrm{~mL})$, then dried over magnesium sulfate, filtered and concentrated in vacuo. Diethyl ether $(300 \mathrm{~mL})$ was added and the resulting mixture was vigorously stirred over 30 minutes. The solid was filtered off and washed with portions of diethyl ether $(5 \times 50 \mathrm{~mL})$ to afford $6 \mathbf{u}(0.602 \mathrm{~g}, 1.72 \mathrm{mmol}, 34 \%$ yield $)$ as a pale brown solid. $\mathrm{R}_{\mathrm{f}} 0.30$ (Dichloromethane:Methanol 95:5); ${ }^{1} \mathrm{H}$ NMR (400 MHz, $\left.\mathrm{CDCl}_{3}\right) \delta 8.36(\mathrm{dt}, J=7.1,1.2$ $\mathrm{Hz}, 1 \mathrm{H}, \operatorname{Ar} H), 7.80(\mathrm{~d}, J=15.7 \mathrm{~Hz}, 1 \mathrm{H}, \operatorname{Ar} H), 7.61-7.40$ (m, 8H, $\operatorname{Ar} H), 7.33$ (d, $J=15.7 \mathrm{~Hz}$, $1 \mathrm{H}, \mathrm{Ar} H) ;{ }^{13} \mathrm{C} \mathrm{NMR}\left(101 \mathrm{MHz}, \mathrm{CDCl}_{3}\right) \delta 167.2,154.3,135.1,133.7,133.4,132.9,131.3$, $130.8,129.3,127.9,126.5,115.6,99.8$. Spectroscopic data was consistent with the values reported in literature. ${ }^{11}$

\section{Phenyl((triisopropylsilyl)ethynyl)iodonium trifluoromethanesulfonate (6v)}<smiles>CC(=O)OI(OC(C)=O)c1ccccc1</smiles>

40
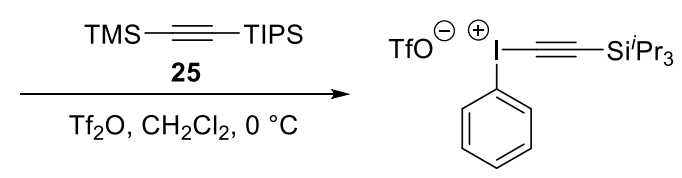

6v

Following a reported procedure, ${ }^{12}$ phenyliodonium diacetate (40) (2.53 g, $7.85 \mathrm{mmol}, 1.00$ eq.) was diluted with $\mathrm{CH}_{2} \mathrm{Cl}_{2}(7 \mathrm{~mL})$ and the mixture was stirred for 5 minutes. Next, triflic anhydride $(0.600 \mathrm{~mL}, 3.90 \mathrm{mmol}, 0.50$ eq. $)$ was added dropwise at $0{ }^{\circ} \mathrm{C}$ and the resulting yellow mixture was stirred for 30 min. To the mixture was added (trimethylsilyl)(triisopropylsilyl)acetylene (25) (2.00 g, $7.86 \mathrm{mmol}, 1.00$ eq.) and stirring continued for 2 hours at $0{ }^{\circ} \mathrm{C}$. Water was then added $(30 \mathrm{~mL})$ and the mixture was extracted

\footnotetext{
${ }^{12}$ R. Frei, J. Waser, J. Am. Chem. Soc. 2013, 135, 9620-9623.
} 
with $\mathrm{CH}_{2} \mathrm{Cl}_{2}(2 \times 30 \mathrm{~mL})$. The combined organic layers were dried over $\mathrm{MgSO}_{4}$, filtered and concentrated in vacuo. The resulting solid was triturated in hexane $(10 \mathrm{~mL})$. Filtration and removal of solvent in vacuo afforded $6 \mathbf{v}(2.90 \mathrm{~g}, 11.2 \mathrm{mmol}, 70 \%)$ as a colorless solid. ${ }^{1} \mathrm{H}$ NMR $\left(400 \mathrm{MHz}, \mathrm{CDCl}_{3}\right) \delta 8.09(\mathrm{~m}, 2 \mathrm{H}, \mathrm{ArH}), 7.65(\mathrm{~m}, 1 \mathrm{H}, \mathrm{ArH}), 7.52(\mathrm{~m}, 2 \mathrm{H}, \mathrm{ArH}), 1.15-1.01$ (m, $21 \mathrm{H}, \mathrm{TIPS}) .{ }^{13} \mathrm{C}$ NMR $\left(100 \mathrm{MHz}, \mathrm{CDCl}_{3}\right) \delta 133.7,132.5,132.4,123.0\left(\mathrm{~J}_{\mathrm{C}-\mathrm{H}}=319 \mathrm{~Hz}\right)$, 117.6, 117.6, 44.9, 18.3, 11.1. IR v 3288 (w), 3088 (m), 2949 (m), 2894 (m), 2869 (w), 1563 (m), 1467 (w), 1451 (w), 1388 (w), 1281 (s), 1236 (s), 1221 (s), 1174 (s), 1068 (w), 1028 (s), $988(\mathrm{~m}), 916(\mathrm{~m}), 884(\mathrm{~m}), 736(\mathrm{~s}), 679(\mathrm{~m}), 639(\mathrm{~s})$. The characterization data is in accordance with reported literature values. ${ }^{12}$ 


\section{Preparation of Thiiranes reagents}

Thiiranes 7a, 7e, $7 \mathbf{f}$ and $\mathbf{7 h}$ were commercially available and bought from Sigma-Aldrich.

\section{Cyclopentene sulfide (7b)}

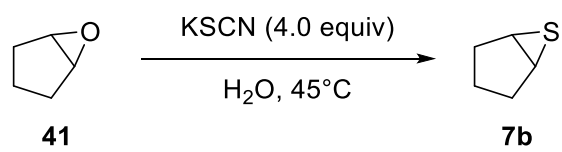

Following a reported procedure, ${ }^{13}$ to a solution of 6-oxabicyclo[3.1.0]hexane (41) $(0.50 \mathrm{~g}, 5.9$ mmol, 1.0 equiv.) in water $(8.9 \mathrm{~mL})$ was added $\mathrm{KSCN}$ ( $2.3 \mathrm{~g}, 24 \mathrm{mmol}, 4.0$ equiv.). The resulting mixture was stirred at $45{ }^{\circ} \mathrm{C}$ for $24 \mathrm{~h}$. The reaction was cooled to $\mathrm{rt}$ and $2 \mathrm{~mL}$ of pentane and brine were added. The crude mixture was extracted with $3 \times 2 \mathrm{~mL}$ of pentane. Combined organic layers were dried over $\mathrm{MgSO}_{4}$ and loaded over a plug of silica, the product was eluted with pentane and concentrated in vacuo to afford $7 \mathbf{b}(0.16 \mathrm{~g}, 1.4 \mathrm{mmol}, 23 \%, 85 \%$ purity) as a colourless oil. ${ }^{1} \mathrm{H}$ NMR (400 MHz, Chloroform- $d$ ) $\delta 3.30(\mathrm{~d}, J=2.4 \mathrm{~Hz}, 2 \mathrm{H}, \mathrm{CHS})$, $2.06\left(\mathrm{dd}, J=13.9,7.0 \mathrm{~Hz}, 2 \mathrm{H}, \mathrm{CH}_{2}\right.$ cyclopentyl), $1.90-1.76$ (m, 2H, CH 2 cyclopentyl), $1.70-$ 1.45 (m, 2H, $\mathrm{CH}_{2}$ cyclopentyl); ${ }^{13} \mathrm{C}$ NMR (100 MHz, Chloroform- $d$ ) $\delta 41.8,29.1,18.2$. Spectroscopic data was consistent with the values reported in literature. ${ }^{13}$

\section{4-Thiocyanatotetrahydrofuran-3-ol (43)}

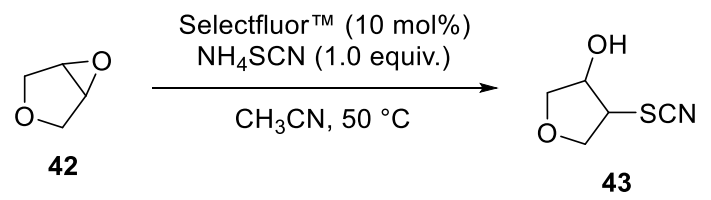

Compound 43 was synthesized following an adapted version of a reported procedure. ${ }^{14} \mathrm{~A}$ solution of 3,6-dioxabicyclo[3.1.0]hexane (42) (2.00 g, $23.2 \mathrm{mmol}, 1.0$ equiv.), $\mathrm{NH}_{4} \mathrm{SCN}$ (1.77 g, $23.2 \mathrm{mmol}, 1.0$ equiv.) and Selectfluor ${ }^{\mathrm{TM}}(0.866 \mathrm{~g}, 2.32 \mathrm{mmol}, 0.1$ equiv.) in acetonitrile (35 $\mathrm{mL}$ ) was stirred at $50{ }^{\circ} \mathrm{C}$ for $48 \mathrm{~h}$. The mixture was concentrated in vacuo, the crude oil was

\footnotetext{
${ }^{13}$ X. Chen, J. Xu, Tetrahedron Lett. 2017, 58, 1651-1654.

14 J. S. Yadav, B. V. S. Reddy, Ch. S. Reddy, Tetrahedron Lett. 2004, 45, 1291-1293.
} 
purified by column chromatography $\left(\mathrm{MeOH} / \mathrm{CH}_{2} \mathrm{Cl}_{2} ; 5: 95\right)$ to afford 43 (2.29 g, $15.8 \mathrm{mmol}$, $68 \%$ ) as a slightly yellow oil. $\mathrm{R}_{\mathrm{f}} 0.25\left(\mathrm{MeOH} / \mathrm{CH}_{2} \mathrm{Cl}_{2} ; 5: 95\right) ;{ }^{1} \mathrm{H} \mathrm{NMR}(400 \mathrm{MHz}$, Chloroformd) $\delta 4.59-4.50(\mathrm{~m}, 1 \mathrm{H}, \mathrm{CHOH}), 4.30\left(\mathrm{dd}, J=10.6,5.7 \mathrm{~Hz}, 1 \mathrm{H}, \mathrm{CH}_{2} \mathrm{O}\right), 4.16(\mathrm{dd}, J=10.2,4.9$ $\left.\mathrm{Hz}, 1 \mathrm{H}, \mathrm{CH}_{2} \mathrm{O}\right), 3.83$ - $3.75\left(\mathrm{~m}, 2 \mathrm{H}, \mathrm{CH}_{2} \mathrm{O}\right), 3.74-3.69(\mathrm{~m}, 1 \mathrm{H}, \mathrm{CHSCN}), 3.22(\mathrm{~s}, 1 \mathrm{H}, \mathrm{OH})$; ${ }^{13} \mathrm{C}$ NMR (100 MHz, Chloroform- $\left.d\right) \delta 111.2,77.2,74.1,70.8,52.7$ IR $\left(v_{\max }, \mathrm{cm}^{-1}\right) 3418(\mathrm{~s})$, 2986 (w), 2883 (w), 2159 (m), 1672 (s), 1416 (s), 1177 (s), 1067 (s), 964 (s), 907 (s), 771 (s), 714 (s). No exact mass could be obtained.

\section{3-Oxa-6-thiabicyclo[3.1.0]hexane (7c)}

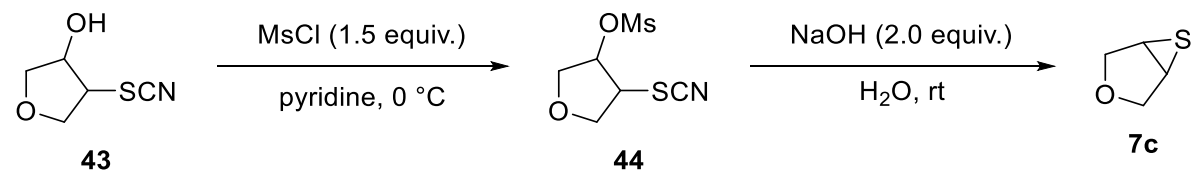

Compound 7c was synthesized following an adapted version of a reported procedure. ${ }^{15}$ To a solution of 4-thiocyanatotetrahydrofuran-3-ol (43) (2.03 g, $20.0 \mathrm{mmol}, 1.0$ equiv.) in pyridine $(8.8 \mathrm{~mL})$ was added $\mathrm{MsCl}\left(1.62 \mathrm{~mL}, 21.0 \mathrm{mmol}, 1.5\right.$ equiv.) under $\mathrm{N}_{2}$ atmosphere at $0{ }^{\circ} \mathrm{C}$. The mixture was allowed to warm to rt and stirred for $18 \mathrm{~h}$. The reaction mixture was diluted with $50 \mathrm{~mL}$ of water and extracted with $3 \times 30 \mathrm{~mL}$ of $\mathrm{CH}_{2} \mathrm{Cl}_{2}$. The combined organic layers were washed successively with $50 \mathrm{~mL}$ of a $1 \mathrm{M}$ aq. sol. of $\mathrm{HCl}$ and water. The organic layer was dried over $\mathrm{MgSO}_{4}$, filtered and concentrated in vacuo to afford crude 4thiocyanatotetrahydrofuran-3-yl methanesulfonate (44). The crude mixture was used directly without further purification. To the resulting crude oil were added water $(52 \mathrm{~mL})$ and $\mathrm{NaOH}$ (1.12 $\mathrm{g}, 28.0 \mathrm{mmol}, 2.0$ equiv.) and the mixture was stirred at $\mathrm{rt}$ for $38 \mathrm{~h}$. The $\mathrm{pH}$ of the reaction mixture was adjusted to $\mathrm{pH}=7$ with addition of $1 \mathrm{M}$ aq. sol. of $\mathrm{HCl}$, the aqueous layer was extracted with 3 x $30 \mathrm{~mL}$ of $\mathrm{CH}_{2} \mathrm{Cl}_{2}$. The combined organic layers were dried over $\mathrm{MgSO}_{4}$, filtered and concentrated in vacuo. The crude orange oil was purified by column chromatography $\left(\mathrm{CH}_{2} \mathrm{Cl}_{2} /\right.$ Pentane; 7:3) to afford 7c $(0.417 \mathrm{~g}, 4.09 \mathrm{mmol}, 29 \%)$ as a yellow oil. $\mathrm{R}_{\mathrm{f}} 0.3$ (AcOEt/Pentane; 1:9); ${ }^{1} \mathrm{H}$ NMR (400 MHz, Chloroform- $d$ ) $\delta 4.05$ (d, $J=10.0 \mathrm{~Hz}, 2 \mathrm{H}$, $\left.\mathrm{CH}_{2} \mathrm{O}\right), 3.83\left(\mathrm{dd}, J=10.1,1.4 \mathrm{~Hz}, 2 \mathrm{H}, \mathrm{CH}_{2} \mathrm{O}\right), 3.44(\mathrm{~d}, J=1.4 \mathrm{~Hz}, 2 \mathrm{H}, \mathrm{CHS}) ;{ }^{13} \mathrm{C}$ NMR $(100$ MHz, Chloroform- $d$ ) $\delta$ 69.3, 38.0; IR ( $\left.v_{\max }, \mathrm{cm}^{-1}\right) 2899$ (m), 2823 (s), 2156 (s), 1669 (s), 1403

\footnotetext{
${ }^{15}$ L. Goodman, B. R. Baker, J. Am. Chem. Soc. 1959, 81, 4924-4926.
} 
(s), 1270 (m), 1216 (s), 1186 (s), 1074 (s), 1035 (m), 905 (s), 718 (s), 708 (s); HRMS (APPI/LTQ-Orbitrap) m/z: [M + H] ${ }^{+}$Calcd for $\mathrm{C}_{4} \mathrm{H}_{7} \mathrm{OS}^{+}$103.0212; Found 103.0207.

\section{Tert-butyl 3-hydroxy-4-thiocyanatopyrrolidine-1-carboxylate (46)}

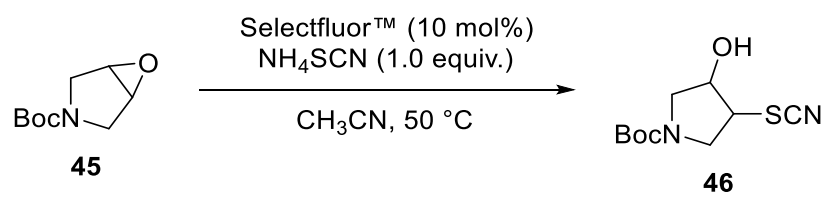

Compound 46 was synthesized following an adapted version of a reported procedure. ${ }^{14} \mathrm{~A}$ solution of tert-butyl 6-oxa-3-azabicyclo[3.1.0]hexane-3-carboxylate (45) (3.00 g, $16.2 \mathrm{mmol}$, 1.0 equiv.), $\mathrm{NH}_{4} \mathrm{SCN}$ (1.23 g, $16.2 \mathrm{mmol}, 1.0$ equiv.) and Selectfluor ${ }^{\mathrm{TM}}$ (0.60 g, $1.6 \mathrm{mmol}, 0.1$ equiv.) in acetonitrile $(24 \mathrm{~mL})$ was stirred at $50{ }^{\circ} \mathrm{C}$ for $48 \mathrm{~h}$. The mixture was concentrated in vacuo, the crude oil was purified by column chromatography $\left(\mathrm{MeOH} / \mathrm{CH}_{2} \mathrm{Cl}_{2} ; 2.5: 97.5\right)$ to afford 46 (2.21 g, $9.06 \mathrm{mmol}, 56 \%)$ an orange solid. $\mathrm{R}_{\mathrm{f}} 0.28\left(\mathrm{MeOH} / \mathrm{CH}_{2} \mathrm{Cl}_{2} ; 5: 95\right) ; \mathrm{Mp}$ : 69-70 ${ }^{\circ} \mathrm{C} ;{ }^{1} \mathrm{H}$ NMR (400 MHz, Chloroform- $d$ ) $\delta 4.47$ (d, $\left.J=19.7 \mathrm{~Hz}, 1 \mathrm{H}, \mathrm{CHOH}\right), 3.94$ (dd, $J=12.6$, $\left.6.5 \mathrm{~Hz}, 1 \mathrm{H}, \mathrm{CH}_{2} \mathrm{~N}\right), 3.87-3.77\left(\mathrm{~m}, 1 \mathrm{H}, \mathrm{CH}_{2} \mathrm{~N}\right), 3.65$ (dt, J=6.5, 4.1 Hz, 1H, CHSCN), $3.55-$ $3.31\left(\mathrm{~m}, 2 \mathrm{H}, \mathrm{CH}_{2} \mathrm{~N}\right), 3.11-2.93(\mathrm{~m}, 1 \mathrm{H}, \mathrm{OH}), 1.46\left(\mathrm{~s}, 9 \mathrm{H}, \mathrm{C}\left(\mathrm{CH}_{3}\right)_{3}\right) .{ }^{13} \mathrm{C} \mathrm{NMR}(100 \mathrm{MHz}$, Chloroform- $d$ ) mixture of rotamers: $\delta 154.3$ (2 peaks), 110.2 (2 peaks), 80.8 (2 peaks), 74.6 (2 peaks), 51.6 (2 peaks), 50.6 (2 peaks), 48.8 (2 peaks), 28.5; IR ( $\left.v_{\max }, \mathrm{cm}^{-1}\right) 3400(\mathrm{w}), 2984(\mathrm{w})$, 2885 (w), 2159 (w), 1675 (s), 1415 (s), 1167 (s), 965 (m), 774 (m); HRMS (ESI/QTOF) m/z: $[\mathrm{M}+\mathrm{Na}]^{+}$Calcd for $\mathrm{C}_{10} \mathrm{H}_{16} \mathrm{~N}_{2} \mathrm{NaO}_{3} \mathrm{~S}^{+}$267.0774; Found 267.0768.

Tert-butyl 6-thia-3-azabicyclo[3.1.0]hexane-3-carboxylate (7d)

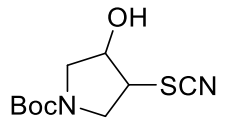

46

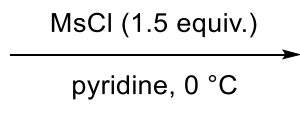

pyridine, $0^{\circ} \mathrm{C}$

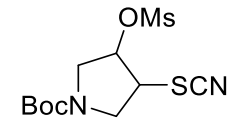

47

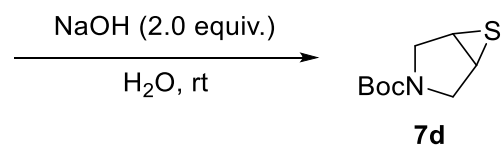

$7 d$

Compound 7d was synthesized following an adapted version of a reported procedure. ${ }^{15}$ To a solution of tert-butyl 3-hydroxy-4-thiocyanatopyrrolidine-1-carboxylate (46) (2.0 g, 8.1 mmol, 1.0 equiv.) in pyridine $(5.0 \mathrm{~mL})$ was added $\mathrm{MsCl}\left(0.94 \mathrm{~mL}, 12 \mathrm{mmol}, 1.5\right.$ equiv.) under $\mathrm{N}_{2}$ atmosphere at $0{ }^{\circ} \mathrm{C}$. The mixture was allowed to warm to $\mathrm{rt}$ and stirred for $22 \mathrm{~h}$. The reaction mixture was diluted with $50 \mathrm{~mL}$ of water and extracted with 3 x $30 \mathrm{~mL}$ of $\mathrm{CH}_{2} \mathrm{Cl}_{2}$. The combined organic layers were washed successively with $50 \mathrm{~mL}$ of a $1 \mathrm{M}$ aq. sol. of $\mathrm{HCl}$ and 
water. The organic layer was dried over $\mathrm{MgSO}_{4}$, filtered and concentrated in vacuo to afford crude tert-butyl 3-((methylsulfonyl)oxy)-4-thiocyanatopyrrolidine-1-carboxylate (47). The crude mixture was used directly without further purification. To the resulting crude oil were added water $(30 \mathrm{~mL})$ and $\mathrm{NaOH}(0.65 \mathrm{~g}, 16 \mathrm{mmol}, 2.0$ equiv. $)$ and the mixture was stirred at $\mathrm{rt}$ for $38 \mathrm{~h}$. The $\mathrm{pH}$ of the reaction mixture was adjusted to $\mathrm{pH}=7$ with addition of $1 \mathrm{M}$ aq. sol. of $\mathrm{HCl}$, the aqueous layer was extracted with $3 \times 30 \mathrm{~mL}$ of $\mathrm{CH}_{2} \mathrm{Cl}_{2}$. The combined organic layers were dried over $\mathrm{MgSO}_{4}$, filtered and concentrated in vacuo. The crude orange oil was purified by column chromatography $\left(\mathrm{CH}_{2} \mathrm{Cl}_{2} /\right.$ Pentane; 7:3) to afford 7d $(1.3 \mathrm{~g}, 6.4 \mathrm{mmol}, 79 \%)$ as a pink solid. $\mathrm{R}_{\mathrm{f}} 0.2$ (AcOEt/Pentane; 1:9); Mp: $47{ }^{\circ} \mathrm{C}{ }^{1} \mathrm{H}$ NMR (400 MHz, Chloroform- $d$ ) $\delta$ $3.97\left(\mathrm{~d}, J=12.6 \mathrm{~Hz}, 1 \mathrm{H}, \mathrm{NCH}_{2}\right), 3.86\left(\mathrm{~d}, J=12.5 \mathrm{~Hz}, 1 \mathrm{H}, \mathrm{NCH}_{2}\right), 3.48$ (dt, $J=12.6,2.4 \mathrm{~Hz}$, $\left.2 \mathrm{H}, \mathrm{NCH}_{2}\right), 3.38-3.29$ (m, 2H, $\left.\mathrm{SCH}\right), 1.43$ (s, 9H, C(CH3) 3 ); ${ }^{13} \mathrm{C} \mathrm{NMR}(100 \mathrm{MHz}$, Chloroformd) mixture of rotamers: $\delta$ 155.7, 80.0, 48.9 (two peaks), 37.5 (two peaks), 28.5; IR ( $\left.v_{\max }, \mathrm{cm}^{-1}\right)$ 2981 (w), 1698 (s), 1408 (s), 1172 (s), 1065 (m), 963 (w); HRMS (APCI/QTOF) m/z: [M + $\mathrm{Na}]^{+}$Calcd for $\mathrm{C}_{9} \mathrm{H}_{15} \mathrm{NNaO}_{2} \mathrm{~S}^{+} 224.0716$; Found 224.0720.

\section{2-Hexylthiirane (7g)}

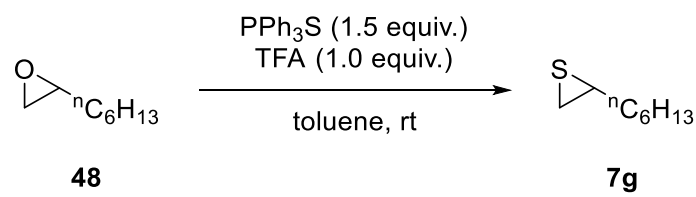

Compound $7 \mathrm{~g}$ was synthesized following an adapted version of a reported procedure. ${ }^{16}$ To a solution of 2-hexyloxirane (48) (1.5 mL, $10 \mathrm{mmol}, 1.0$ equiv.) and $\mathrm{PPh}_{3} \mathrm{~S}$ (4.4 g, $15 \mathrm{mmol}, 1.5$ equiv.) in toluene $(35 \mathrm{~mL})$ was added dropwise a solution of TFA $(0.77 \mathrm{~mL}, 10 \mathrm{mmol}, 1.0$ equiv.) in toluene $(5 \mathrm{~mL})$. The reaction was stirred at $\mathrm{rt}$ for $16 \mathrm{~h}$ then quenched by the addition of $50 \mathrm{~mL}$ of a sat. sol. of $\mathrm{NaHCO}_{3}$ and stirred for $15 \mathrm{~min}$. $\mathrm{Et}_{2} \mathrm{O}(50 \mathrm{~mL})$ was added and the two layers were separated. The aqueous layer was washed with $2 \times 30 \mathrm{~mL}$ of $\mathrm{Et}_{2} \mathrm{O}$. The combined organic layers were dried over $\mathrm{MgSO}_{4}$, filtered and concentrated in vacuo. The resulting white solid was suspended in pentane, filtered and washed with pentane. The pentane solution was concentrated in vacuo and the resulting crude oil was purified by column chromatography (pentane) to afford $7 \mathrm{~g}(0.93 \mathrm{~g}, 6.5 \mathrm{mmol}, 65 \%)$ as a colorless oil. $\mathrm{R}_{\mathrm{f}} 0.37$ (Pentane) ${ }^{1} \mathrm{H}$ NMR

\footnotetext{
${ }^{16}$ T. H. Chan, J. R. Finkenbine, J. Am. Chem. Soc. 1972, 94, 2880-2882.
} 
(400 MHz, Chloroform- $d$ ) $\delta 2.93-2.83(\mathrm{~m}, 1 \mathrm{H}, \mathrm{CHS}), 2.50\left(\mathrm{dd}, J=6.3,1.0 \mathrm{~Hz}, 1 \mathrm{H}, \mathrm{CH}_{2} \mathrm{~S}\right.$ ), $2.15\left(\mathrm{dd}, J=5.7,1.0 \mathrm{~Hz}, 1 \mathrm{H}, \mathrm{CH}_{2} \mathrm{~S}\right), 1.89-1.75\left(\mathrm{~m}, 1 \mathrm{H}, \mathrm{CH}_{2}\right.$ hexyl), $1.58-1.41\left(\mathrm{~m}, 3 \mathrm{H}, \mathrm{CH}_{2}\right.$ hexyl), $1.39-1.22\left(\mathrm{~m}, 6 \mathrm{H}, \mathrm{CH}_{2}\right.$ hexyl), $0.94-0.84$ (m, 3H, $\left.\mathrm{CH}_{2} \mathrm{CH}_{3}\right) ;{ }^{13} \mathrm{C} \mathrm{NMR}(100 \mathrm{MHz}$, Chloroform- $d$ ) $\delta 36.7,36.2,31.9,29.5,29.1,26.1,22.7,14.2$. Spectroscopic data was consistent with the values reported in literature. ${ }^{13}$

\section{(S)-Triisopropyl(oxiran-2-ylmethoxy)silane (50)}

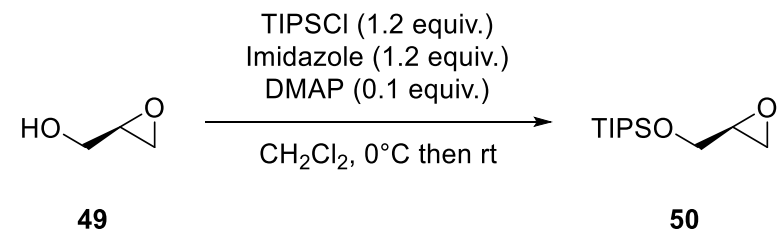

Following a reported procedure, ${ }^{17}$ to a cold $\left(0{ }^{\circ} \mathrm{C}\right)$ solution of $(R)$-oxiran-2-ylmethanol (49) $(2.5$ g, 34 mmol, 1.0 equiv.) in $\mathrm{CH}_{2} \mathrm{Cl}_{2}(56 \mathrm{~mL})$ were added imidazole (2.8 g, $41 \mathrm{mmol}, 1.2$ equiv.) and TIPSCl ( $8.7 \mathrm{~mL}, 41 \mathrm{mmol}, 1.2$ equiv.). The mixture was warmed to $\mathrm{rt}$ and stirred for $1.5 \mathrm{~h}$. The reaction mixture was filtered on celite, $80 \mathrm{~mL}$ of water and $50 \mathrm{~mL}$ of pentane were added to the filtrate and the two layers were separated. The aqueous layer was extracted with $3 \times 50$ $\mathrm{mL}$ of pentane. Combined organic layers were washed successively with $80 \mathrm{~mL}$ of water and 2 x $80 \mathrm{~mL}$ of brine, dried over $\mathrm{MgSO}_{4}$, filtered and concentrated in vacuo. The crude product was purified by column chromatography ( $\mathrm{Et}_{2} \mathrm{O} / \mathrm{Pentane} ; 5: 95$ to 1:9) to afford $\mathbf{5 0}$ (7.6 g, $33 \mathrm{mmol}$, 97\%) as a colorless oil. ${ }^{1} \mathrm{H}$ NMR (400 MHz, Chloroform- $d$ ) $\delta 3.91$ (dd, $J=11.6,3.3 \mathrm{~Hz}, 1 \mathrm{H}$, TIPSO-CH $\mathrm{CH}_{2}, 3.75$ (dd, $J=11.7,4.7 \mathrm{~Hz}, 1 \mathrm{H}$, TIPSO-CH $\left.\mathrm{C}_{2}\right), 3.16-3.05(\mathrm{~m}, 1 \mathrm{H}, \mathrm{OCH}), 2.77$ (dd, $\left.J=5.3,4.0 \mathrm{~Hz}, 1 \mathrm{H}, \mathrm{OCH}_{2}\right), 2.66\left(\mathrm{dd}, J=5.2,2.6 \mathrm{~Hz}, 1 \mathrm{H}, \mathrm{OCH}_{2}\right), 1.18-0.97(\mathrm{~m}, 21 \mathrm{H}, \mathrm{TIPS})$; ${ }^{13} \mathrm{C}$ NMR (101 MHz, Chloroform- $d$ ) $\delta 64.1,52.7,44.6,18.1,12.1$. Spectroscopic data was consistent with the values reported in literature. ${ }^{17}$

(R)-Triisopropyl(thiiran-2-ylmethoxy)silane (7i)

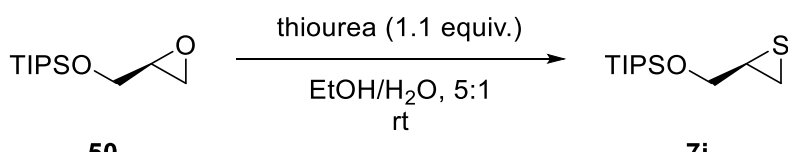

\footnotetext{
${ }^{17}$ S. Hoppen, S. Bäurle, U. Koert, Chem. - Eur. J. 2000, 6, 2382-2396.
} 
Synthesized following an adapted version of a reported procedure. ${ }^{18}$ A solution of $(S)$ triisopropyl(oxiran-2-ylmethoxy)silane (50) (2.0 g, $8.7 \mathrm{mmol}, 1.0$ equiv.) and thiourea (0.73 g, $9.6 \mathrm{mmol}, 1.1$ equiv.) in a mixture of ethanol $(4.25 \mathrm{~mL})$ and water $(0.85 \mathrm{~mL})$ was stirred at $\mathrm{rt}$ for $24 \mathrm{~h}$. The reaction was concentrated in vacuo then water $(20 \mathrm{~mL})$ and $\mathrm{CH}_{2} \mathrm{Cl}_{2}(20 \mathrm{~mL})$ were added. The two layers were separated and the aqueous layer was extracted with $3 \times 20 \mathrm{~mL}$ of $\mathrm{CH}_{2} \mathrm{Cl}_{2}$. Combined organic layers were dried over $\mathrm{MgSO}_{4}$, filtered and concentrated in vacuo. The crude mixture was purified by column chromatography (Toluene/Pentane; 15:85) to afford $7 \mathbf{i}\left(1.6 \mathrm{~g}, 6.6 \mathrm{mmol}, 76 \%\right.$ ) as a colorless oil. $\mathrm{R}_{\mathrm{f}} 0.73$ (Toluene/Pentane; 1:3); ${ }^{1} \mathrm{H}$ NMR (400 MHz, Chloroform- $d$ ) $\delta 3.97\left(\mathrm{dd}, J=10.6,4.9 \mathrm{~Hz}, 1 \mathrm{H}, \mathrm{OTIPS}-\mathrm{CH}_{2}\right), 3.61(\mathrm{dd}, J=10.8,6.8 \mathrm{~Hz}$, 1H, OTIPS-CH$), 3.14-3.02(\mathrm{~m}, 1 \mathrm{H}, \mathrm{SCH}), 2.54-2.46\left(\mathrm{~m}, 1 \mathrm{H}, \mathrm{SCH}_{2}\right), 2.24(\mathrm{dd}, J=5.4,1.2$ $\left.\mathrm{Hz}, 1 \mathrm{H}, \mathrm{SCH}_{2}\right), 1.19$ - 0.94 (m, 21H, TIPS); ${ }^{13} \mathrm{C}$ NMR (100 MHz, Chloroform- $d$ ) $\delta$ 68.3, 35.1, 24.1, 18.1, 12.2; IR ( $\left.v_{\max }, \mathrm{cm}^{-1}\right) 2946$ (s), 2865 (s), $1464(\mathrm{~m}), 1388(\mathrm{w}), 1095$ (s), $884(\mathrm{~m}), 794$ (s), 685 (s); HRMS (APPI/QTOF) m/z: $[\mathrm{M}+\mathrm{H}]^{+}$Calcd for $\mathrm{C}_{12} \mathrm{H}_{27} \mathrm{OSSi}^{+}$247.1546; Found 247.1538 .

\section{(Z)-1,4-Bis(benzyloxy)but-2-ene (52)}

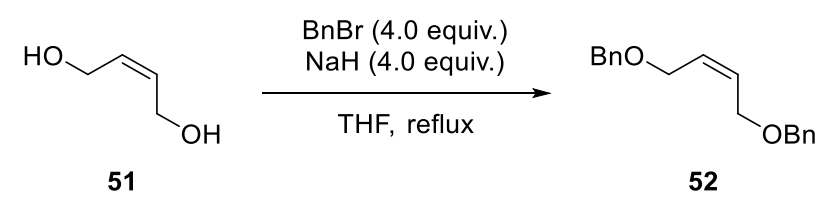

Following a reported procedure, ${ }^{19}$ to a cooled $\left(0{ }^{\circ} \mathrm{C}\right)$ suspension of $\mathrm{NaH}(60 \%$ dispersion in mineral oil, $0.80 \mathrm{~g}, 20 \mathrm{mmol}, 4.0$ equiv.) in THF ( $8.1 \mathrm{~mL})$ was added dropwise (Z)-but-2-ene1,4-diol (51) (0.41 mL, $5.0 \mathrm{mmol}, 1.0$ equiv.). The mixture was stirred under reflux for $2 \mathrm{~h}$ then cooled to rt. A solution of $\mathrm{BnBr}(2.4 \mathrm{~mL}, 20 \mathrm{mmol}, 4.0$ equiv.) in THF (8.1 mL) was added dropwise, the mixture was stirred under reflux for $1 \mathrm{~h}$, cooled to $\mathrm{rt}$ an stirred for $24 \mathrm{~h}$. The mixture was cooled to $0{ }^{\circ} \mathrm{C}$, quenched with a slow addition of $15 \mathrm{~mL}$ of water and concentrated in vacuo. The resulting mixture was extracted with $3 \times 20 \mathrm{~mL}$ of DCM. Combined organic layers were washed successively with $20 \mathrm{~mL}$ of a sat. sol. of $\mathrm{NH}_{4} \mathrm{Cl}, 20 \mathrm{~mL}$ of water and 20 $\mathrm{mL}$ of brine, dried over $\mathrm{MgSO}_{4}$, filtered and concentrated in vacuo. The crude product was

\footnotetext{
${ }^{18}$ H. Bouda, M. E. Borredon, M. Delmas, A. Gaset, Synth. Commun. 1989, 19, 491-500.

${ }^{19}$ F.-L. Wu, B. P. Ross, R. P. McGeary, Eur. J. Org. Chem. 2010, 2010, 1989-1998.
} 
purified by column chromatography (AcOEt/Pentane; 5:95) to afford $\mathbf{5 2}(1.1 \mathrm{~g}, 4.0 \mathrm{mmol}, 80 \%)$ as a colorless oil. ${ }^{1} \mathrm{H}$ NMR (400 MHz, Chloroform- $d$ ) $\delta 7.41-7.27(\mathrm{~m}, 10 \mathrm{H}, \mathrm{Ph} H), 5.80(\mathrm{t}, J=$ $3.8 \mathrm{~Hz}, 2 \mathrm{H}, \mathrm{CH}=\mathrm{CH}), 4.50\left(\mathrm{~s}, 4 \mathrm{H}, \mathrm{PhCH}_{2} \mathrm{O}\right), 4.07\left(\mathrm{~d}, \mathrm{~J}=4.9 \mathrm{~Hz}, 4 \mathrm{H}, \mathrm{OCH}_{2} \mathrm{CH}=\mathrm{CH}\right) ;{ }^{13} \mathrm{C} \mathrm{NMR}$ (100 MHz, Chloroform- $d$ ) $\delta 138.3,129.7,128.6,127.9,127.8,72.4,65.9$. Spectroscopic data was consistent with the values reported in literature. ${ }^{19}$

\section{2,3-Bis((benzyloxy)methyl)oxirane (53)}

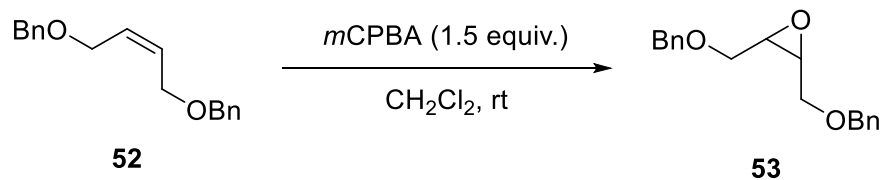

Following a reported procedure, ${ }^{20}$ to a cooled $\left(0{ }^{\circ} \mathrm{C}\right)$ solution of $(Z)-1,4$-bis(benzyloxy)but-2ene (52) (1.08 g, $4.00 \mathrm{mmol}, 1.0$ equiv.) in $\mathrm{CH}_{2} \mathrm{Cl}_{2}(4.0 \mathrm{~mL})$ was added dropwise a solution of $m$ CPBA (1.35 g, $6.01 \mathrm{mmol}, 1.5$ equiv.) in $\mathrm{CH}_{2} \mathrm{Cl}_{2}(6.5 \mathrm{~mL})$ over 15 minutes. The mixture was warm to $\mathrm{rt}$ and stirred for $24 \mathrm{~h}$. The mixture was cooled to $0{ }^{\circ} \mathrm{C}$, filtered through a plug of silica and eluted with cold $\mathrm{CH}_{2} \mathrm{Cl}_{2}(40 \mathrm{~mL})$. The resulting solution was washed sequentially with 20 $\mathrm{mL}$ of a sat. sol. of $\mathrm{NaHCO}_{3}, 20 \mathrm{~mL}$ of a sat. sol. of $\mathrm{Na}_{2} \mathrm{~S}_{2} \mathrm{O}_{3}$ and $20 \mathrm{~mL}$ of brine. The organic layer was dried over $\mathrm{MgSO}_{4}$, filtered and concentrated in vacuo. The crude product was purified by column chromatography (AcOEt/Pentane; 5:95) to afford 53 (0.536 g, $1.88 \mathrm{mmol}, 47 \%$ ) as a colorless oil. ${ }^{1} \mathrm{H}$ NMR (400 MHz, Chloroform- $\left.d\right) \delta 7.39-7.27(\mathrm{~m}, 10 \mathrm{H}, \mathrm{PhH}), 4.62(\mathrm{~d}, J=$ $11.9 \mathrm{~Hz}, 2 \mathrm{H}, \mathrm{PhCH}_{2} \mathrm{O}$ ), 4.52 (d, $\left.J=11.9 \mathrm{~Hz}, 2 \mathrm{H}, \mathrm{PhCH}_{2} \mathrm{O}\right), 3.69$ (dd, $J=11.2,3.8 \mathrm{~Hz}, 2 \mathrm{H}$, $\left.\mathrm{OCH}_{2} \mathrm{CH}\right), 3.58-3.49\left(\mathrm{~m}, 2 \mathrm{H}, \mathrm{OCH}_{2} \mathrm{CH}\right), 3.30-3.23(\mathrm{~m}, 2 \mathrm{H}, \mathrm{CHO}) ;{ }^{13} \mathrm{C} \mathrm{NMR}(100 \mathrm{MHz}$, Chloroform- $d$ ) $\delta 137.9,128.6,128.0,127.9,73.4,68.2$, 54.6. Spectroscopic data was consistent with the values reported in literature. ${ }^{20}$

\section{2,3-Bis((benzyloxy)methyl)thiirane (7j)}

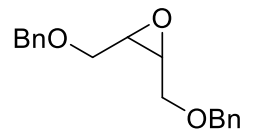

53

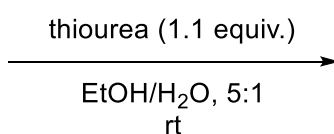

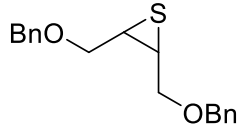

$7 \mathbf{j}$

${ }^{20}$ Y. Schmidt, B. Breit, Chem. - Eur. J. 2011, 17, 11780-11788. 
Compound 7j was synthesized following an adapted version of a reported procedure. ${ }^{18} \mathrm{~A}$ solution of 2,3-bis((benzyloxy)methyl)oxirane (53) (305 mg, $1.07 \mathrm{mmol}, 1.0$ equiv.) and thiourea (90 mg, $1.2 \mathrm{mmol}, 1.1$ equiv.) in a mixture of water $(105 \mu \mathrm{L})$ and ethanol $(530 \mu \mathrm{L})$ was stirred at $\mathrm{rt}$ for $65 \mathrm{~h}$. The reaction was concentrated in vacuo. The crude mixture was purified by column chromatography (AcOEt/Pentane; 5:95 then 10:90) to afford 7j (136 mg, $0.452 \mathrm{mmol}, 42 \%)$ as a colorless oil and unreacted 53 (143 $\mathrm{mg}, 0.504 \mathrm{mmol}, 47 \%)$. Rf 0.47 (AcOEt/Pentane; 1:9) ${ }^{1} \mathrm{H}$ NMR (400 MHz, Chloroform- $d$ ) $\delta 7.38-7.27$ (m, 10H, $\mathrm{Ph} H$ ), 4.60 $\left(\mathrm{d}, J=12.0 \mathrm{~Hz}, 2 \mathrm{H}, \mathrm{PhCH}_{2} \mathrm{O}\right), 4.54\left(\mathrm{~d}, J=11.9 \mathrm{~Hz}, 2 \mathrm{H}, \mathrm{PhCH}_{2} \mathrm{O}\right), 3.72-3.65(\mathrm{~m}, 4 \mathrm{H}$, $\mathrm{OCH}_{2} \mathrm{CH}$ ), $3.26-3.18$ (m, 2H, CHS); ${ }^{13} \mathrm{C}$ NMR (100 MHz, Chloroform- $d$ ) $\delta$ 138.0, 128.6, $127.9,127.9,73.3,70.2$, 36.7. Spectroscopic data was consistent with the values reported in literature. $^{19}$ 


\section{Preparation of Thietanes reagents}

Thiethane 9a was commercially available and purchased from Sigma-Aldrich.

\section{(1,3-Dibromopropan-2-yl)benzene (55)}

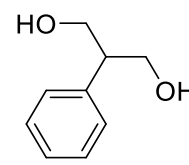

54

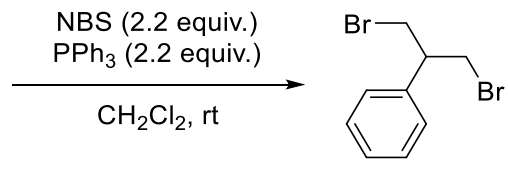

55

Following a reported procedure, ${ }^{21}$ to a cold $\left(0{ }^{\circ} \mathrm{C}\right)$ solution of 2-phenylpropane-1,3-diol (54) (1.00 g, 6.57 mmol, 1.0 equiv.) and $\mathrm{PPh}_{3}$ (3.79 g, 14.5 mmol, 2.2 equiv.) in $\mathrm{CH}_{2} \mathrm{Cl}_{2}$ (33 mL) was added NBS (2.57 g, $14.5 \mathrm{mmol}, 2.2$ equiv.). The mixture was warmed to rt and stirred for $4.5 \mathrm{~h}$. The mixture was concentrated in vacuo, the resulting crude product was purified by column chromatography (Et ${ }_{2} \mathrm{O} /$ Pentane; 0:100 to 1:99) to afford 55 (1.48 g, $5.32 \mathrm{mmol}, 81 \%$ ) as a colorless oil. ${ }^{1} \mathrm{H}$ NMR (400 MHz, Chloroform- $d$ ) $\delta 7.40-7.30(\mathrm{~m}, 3 \mathrm{H}, \mathrm{ArH}), 7.25-7.20$ $(\mathrm{m}, 2 \mathrm{H}, \mathrm{ArH}), 3.80\left(\mathrm{dd}, J=10.3,6.8 \mathrm{~Hz}, 2 \mathrm{H}, \mathrm{CH}_{2} \mathrm{Br}\right.$ ), $3.73\left(\mathrm{dd}, J=10.3,6.3 \mathrm{~Hz}, 2 \mathrm{H}, \mathrm{CH}_{2} \mathrm{Br}\right.$ ), $3.39(\mathrm{p}, J=6.6 \mathrm{~Hz}, 1 \mathrm{H}, \mathrm{PhCH}) ;{ }^{13} \mathrm{C}$ NMR (101 MHz, Chloroform- $d$ ) $\delta$ 139.7, 128.9, 128.1, $127.7,49.1,35.7$. Spectroscopic data was consistent with the values reported in literature. ${ }^{21}$

\section{3-Phenylthietane (9b)}

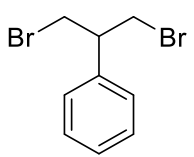

55

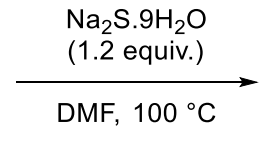

DMF, $100^{\circ} \mathrm{C}$

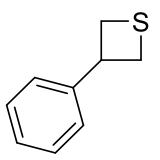

$9 b$

Following a reported procedure, ${ }^{21}$ to a solution of (1,3-dibromopropan-2-yl)benzene (55) (0.80 g, 2.9 mmol, 1.0 equiv. $)$ in dry DMF $(19.2 \mathrm{~mL})$ was added portion wise $\mathrm{Na}_{2} \mathrm{~S} \cdot 9 \mathrm{H}_{2} \mathrm{O}(0.83 \mathrm{~g}$, $3.5 \mathrm{mmol}, 1.2$ equiv.). The mixture was stirred at $100{ }^{\circ} \mathrm{C}$ for $8 \mathrm{~h}$. The reaction was quenched with $50 \mathrm{~mL}$ of water and extracted with $3 \times 40 \mathrm{~mL}$ of AcOEt. Combined organic layers were dried over $\mathrm{MgSO}_{4}$, filtered and concentrated in vacuo. The crude product was purified by

\footnotetext{
${ }^{21}$ T. Zheng, J. Tan, R. Fan, S. Su, B. Liu, C. Tan, K. Xu, Chem. Commun. 2018, 54, 1303-1306.
} 
column chromatography ( $\mathrm{Et}_{2} \mathrm{O} / \mathrm{Pentane}$; 0:100 to 4:96) to afford $9 \mathbf{b}$ (76 mg, $0.50 \mathrm{mmol}, 17 \%$ ) as a colorless oil. ${ }^{1} \mathrm{H}$ NMR (400 MHz, Chloroform- $d$ ) $\delta 7.35-7.16(\mathrm{~m}, 5 \mathrm{H}, \mathrm{PhH}), 4.53(\mathrm{p}, J=$ $9.0 \mathrm{~Hz}, 1 \mathrm{H}, \mathrm{CH}), 3.57\left(\mathrm{t}, J=9.1 \mathrm{~Hz}, 2 \mathrm{H}, \mathrm{SCH}_{2}\right), 3.32\left(\mathrm{t}, J=8.9 \mathrm{~Hz}, 2 \mathrm{H}, \mathrm{SCH}_{2}\right) ;{ }^{13} \mathrm{C} \mathrm{NMR}(100$ MHz, Chloroform- $d$ ) $\delta 144.2,128.8,127.1,126.0,45.3,33.2$. Spectroscopic data was consistent with the values reported in literature. ${ }^{21}$

\section{7,7-Dimethyl-6,8-dioxa-2-thiaspiro[3.5]nonane (9c)}

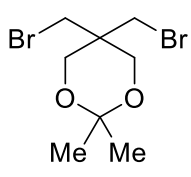

56

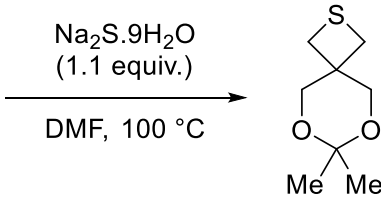

9c

Following a reported procedure, ${ }^{21}$ to a solution of 5,5-bis(bromomethyl)-2,2-dimethyl-1,3dioxane (56) (0.97 g, $3.2 \mathrm{mmol}, 1.0$ equiv.) in dry DMF (12.8 mL) was added portion wise $\mathrm{Na}_{2} \mathrm{~S} \cdot 9 \mathrm{H}_{2} \mathrm{O}$ (0.84 mg, $3.5 \mathrm{mmol}, 1.1$ equiv.). The mixture was stirred at $100{ }^{\circ} \mathrm{C}$ for $6 \mathrm{~h}$. The reaction was quenched with $50 \mathrm{~mL}$ of water and extracted with $3 \times 50 \mathrm{~mL}$ of $\mathrm{Et}_{2} \mathrm{O}$. Combined organic layers were dried over $\mathrm{MgSO}_{4}$, filtered and concentrated in vacuo. The crude product was purified by column chromatography (AcOEt/Pentane; 5:95) to afford 9c $(0.49 \mathrm{~g}, 2.8 \mathrm{mmol}$, $88 \%$ ) as a white solid. ${ }^{1} \mathrm{H}$ NMR (400 MHz, Chloroform- $d$ ) $\delta 3.88\left(\mathrm{~s}, 4 \mathrm{H}, \mathrm{OCH}_{2}\right), 2.97$ (s, 4H, $\left.\mathrm{SCH}_{2}\right), 1.38$ (s, 6H, $\left.\mathrm{C}\left(\mathrm{CH}_{3}\right)_{2}\right) ;{ }^{13} \mathrm{C} \mathrm{NMR}$ (100 MHz, Chloroform- $d$ ) $\delta$ 98.1, 68.5, 41.2, 30.9, 23.7. Spectroscopic data was consistent with the values reported in literature. ${ }^{21}$

\section{2-Oxa-6-thiaspiro[3.3]heptane (9d)}

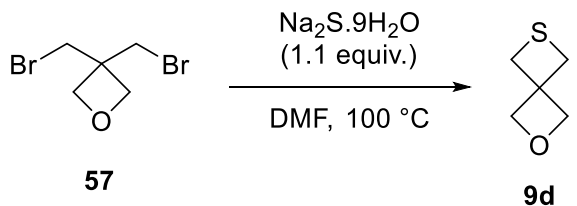

Compound 9d was synthesized following an adapted version of a reported procedure. ${ }^{21}$ To an oven dried 2-neck round bottom flask were added 3,3-bis(bromomethyl)oxetane (57) (1.5 g, 6.2 mmol, 1.0 equiv.) and dry DMF (25 mL) then $\mathrm{Na}_{2} \mathrm{~S} \bullet 9 \mathrm{H}_{2} \mathrm{O}(1.6 \mathrm{~g}, 6.8 \mathrm{mmol}, 1.1$ equiv.) was added portionwise. The mixture was stirred at $50{ }^{\circ} \mathrm{C}$ for $6.5 \mathrm{~h}$. The reaction was cooled to rt and quenched by the addition of $50 \mathrm{~mL}$ of water. The resulting mixture was extracted with $3 \mathrm{x}$ 
$50 \mathrm{~mL}$ of AcOEt. Combined organic layers were dried over $\mathrm{MgSO}_{4}$, filtered and concentrated in vacuo. The crude product was purified by column chromatography (AcOEt/PE; 1:9) to afford 9d (0.32 g, $2.7 \mathrm{mmol}, 44 \%)$ as an orange oil. $\mathrm{R}_{\mathrm{f}} 0.29$ (AcOEt/Pentane; 1:9); ${ }^{1} \mathrm{H}$ NMR (400 $\mathrm{MHz}$, Chloroform- $d$ ) $\delta 4.67\left(\mathrm{~s}, 4 \mathrm{H}, \mathrm{OCH}_{2}\right), 3.39\left(\mathrm{~s}, 4 \mathrm{H}, \mathrm{SCH}_{2}\right) ;{ }^{13} \mathrm{C} \mathrm{NMR}(100 \mathrm{MHz}$, Chloroform- $d$ ) $\delta$ 84.6, 48.0, 36.1; IR ( $\left.v_{\max }, \mathrm{cm}^{-1}\right) 2932(\mathrm{~m}), 2858(\mathrm{~m}), 1179(\mathrm{w}), 976(\mathrm{~s}), 836$ (m); HRMS (APCI/QTOF) m/z: [M + H] $]^{+}$Calcd for $\mathrm{C}_{5} \mathrm{H}_{9} \mathrm{OS}^{+}$117.0369; Found 117.0367. 


\section{Oxy-alkynylation}

\section{General procedure A: Oxy-akynylation of thiiranes}
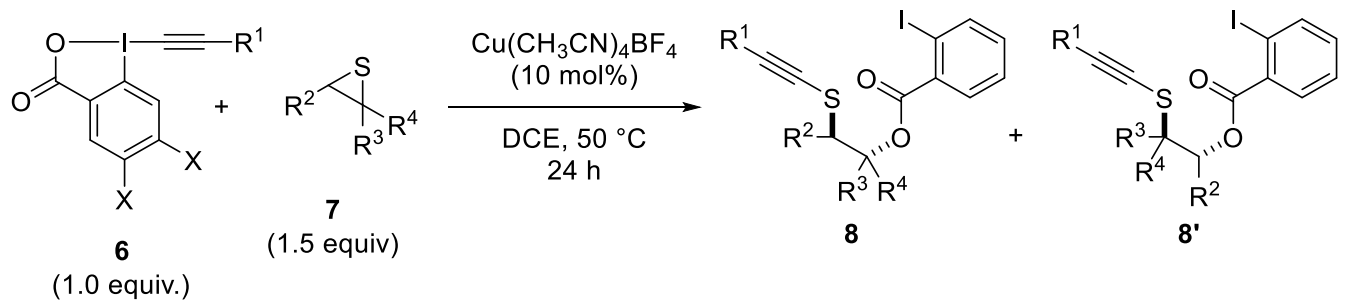

To a microwave vial containing hypervalent iodine reagent $(\mathbf{6})(0.20 \mathrm{mmol}, 1$ equiv.) was added $\mathrm{Cu}\left(\mathrm{CH}_{3} \mathrm{CN}\right)_{4} \mathrm{BF}_{4}\left(6.3 \mathrm{mg}, 20 \mu \mathrm{mol}, 0.1\right.$ equiv.) under $\mathrm{N}_{2}$ atmosphere. The vial was sealed, DCE $(2.5 \mathrm{~mL})$ and a solution of thiirane $(7)(0.30 \mathrm{mmol}, 1.5$ equiv. $)$ in DCE $(0.5 \mathrm{~mL})$ were added under $\mathrm{N}_{2}$ atmosphere. The resulting mixture was stirred at $50{ }^{\circ} \mathrm{C}$ for $24 \mathrm{~h}$ (unless otherwise indicated). The reaction was cooled to $\mathrm{rt}$ and concentrated in vacuo. The crude product was purified as described.

\section{2-(((Triisopropylsilyl)ethynyl)thio)cyclohexyl 2-iodobenzoate (8a)}

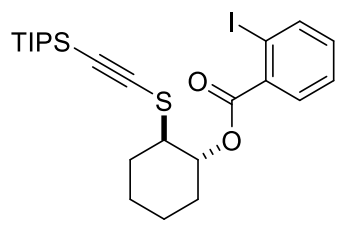

$8 a$

To a microwave vial containing TIPS-EBX (6a) (43 mg, $0.10 \mathrm{mmol}, 1.0$ equiv.) was added $\mathrm{Cu}\left(\mathrm{CH}_{3} \mathrm{CN}\right)_{4} \mathrm{BF}_{4}$ (3.2 mg, $0.010 \mathrm{mmol}, 0.1$ equiv.) under $\mathrm{N}_{2}$ atmosphere. The vial was sealed then DCE $(1.5 \mathrm{~mL})$ and cyclohexene sulfide (7a) $(16 \mu \mathrm{L}, 0.15 \mathrm{mmol}, 1.5$ equiv.) were added under $\mathrm{N}_{2}$ atmosphere. The resulting mixture was stirred at $50{ }^{\circ} \mathrm{C}$ for $1.5 \mathrm{~h}$. The reaction was cooled to $\mathrm{rt}$ and concentrated in vacuo. The crude oil was purified by preparative TLC (Toluene/Pentane; 1:3) to afford $\mathbf{8 a}(35 \mathrm{mg}, 0.065 \mathrm{mmol}, 65 \%)$ as a colorless oil. The compound crystallized as a white solid after long-time storage in a freezer at $-5{ }^{\circ} \mathrm{C}$. Mp: $50{ }^{\circ} \mathrm{C}$. $\mathrm{R}_{\mathrm{f}} 0.4$ (Toluene/Pentane; 1:3); ${ }^{1} \mathrm{H}$ NMR (400 MHz, Chloroform- $d$ ) $\delta 7.97$ (dd, $J=7.9,1.1 \mathrm{~Hz}, 1 \mathrm{H}$, $\operatorname{Ar} H), 7.84(\mathrm{dd}, J=7.8,1.7 \mathrm{~Hz}, 1 \mathrm{H}, \operatorname{Ar} H), 7.40(\mathrm{td}, J=7.6,1.2 \mathrm{~Hz}, 1 \mathrm{H}, \operatorname{Ar} H), 7.14(\mathrm{td}, J=7.7$, $1.7 \mathrm{~Hz}, 1 \mathrm{H}, \operatorname{Ar} H), 5.05(\mathrm{td}, J=10.0,4.4 \mathrm{~Hz}, 1 \mathrm{H}, \mathrm{OCH}), 2.95(\mathrm{ddd}, J=11.3,9.8,4.2 \mathrm{~Hz}, 1 \mathrm{H}$, 
$\mathrm{SCH}), 2.43-2.24\left(\mathrm{~m}, 2 \mathrm{H}, \mathrm{CH}_{2}\right.$ cyclohexyl), $1.93-1.75$ (m, 3H, $\mathrm{CH}_{2}$ cyclohexyl), $1.62-1.34$ (m, 3H, CH $\mathrm{CH}_{2}$ cyclohexyl), 1.08 (s, 21H, TIPS); ${ }^{13} \mathrm{C}$ NMR (100 MHz, Chloroform-d) $\delta 165.7$, 141.2, 135.7, 132.6, 131.0, 128.0, 100.1, 94.1, 92.5, 75.0, 50.5, 32.0, 31.9, 25.5, 24.0, 18.8, 11.5; IR ( $\left.v_{\max }, \mathrm{cm}^{-1}\right) 2942(\mathrm{~s}), 2865$ (s), 2089 (m), 1731 (s), 1460 (m), 1283 (s), 1253 (s), 1103 (m), 1014 (m), 867 (m), 741 (s), 674 (s); HRMS (ESI) m/z: [M+Na] calcd for $\mathrm{C}_{24} \mathrm{H}_{35} \mathrm{INaO}_{2} \mathrm{SSi}^{+}$ 565.1064; found 565.1070.

2-(((Triisopropylsilyl)ethynyl)thio)cyclopentyl 2-iodobenzoate (8b)

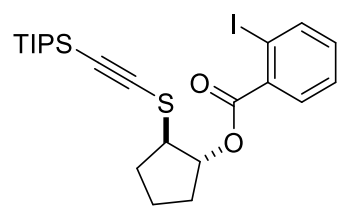

8b

Synthesized following general procedure A starting from TIPS-EBX (6a) (86 mg, 0.20 mmol) and cyclopentene sulfide $(\mathbf{7 b})(35 \mathrm{mg}, 0.30 \mathrm{mmol})$. The crude oil was purified by column chromatography (AcOEt/Pentane; 1:99) to afford $\mathbf{8 b}$ (75 $\mathrm{mg}, 0.14 \mathrm{mmol}, 71 \%$ ) as a light yellow oil. $\mathrm{R}_{\mathrm{f}} 0.43$ (Toluene/Pentane; 1:3); ${ }^{1} \mathrm{H}$ NMR (400 MHz, Chloroform- $d$ ) $\delta 7.98$ (dd, $J=8.0,1.2$ $\mathrm{Hz}, 1 \mathrm{H}, \mathrm{Ar} H), 7.75(\mathrm{dd}, J=7.8,1.7 \mathrm{~Hz}, 1 \mathrm{H}, \mathrm{Ar} H), 7.40$ (td, $J=7.6,1.2 \mathrm{~Hz}, 1 \mathrm{H}, \mathrm{ArH}), 7.14(\mathrm{td}$, $J=7.7,1.7 \mathrm{~Hz}, 1 \mathrm{H}, \mathrm{ArH}), 5.49-5.41(\mathrm{~m}, 1 \mathrm{H}, \mathrm{OCH}), 3.56-3.48(\mathrm{~m}, 1 \mathrm{H}, \mathrm{SCH}), 2.38-2.23$ (m, 2H, $\mathrm{CH}_{2}$ cyclopentyl), $1.98-1.83$ (m, 4H, $\mathrm{CH}_{2}$ cyclopentyl), 1.07 (m, 21H, TIPS); ${ }^{13} \mathrm{C}$ NMR (100 MHz, Chloroform-d) $\delta$ 165.9, 141.4, 135.6, 132.7, 131.1, 128.0, 99.2, 94.0, 93.6, 82.2, 51.6, 31.7, 30.7, 23.1, 18.8, 11.5; IR $\left(v_{\max }, \mathrm{cm}^{-1}\right) 2948(\mathrm{~m}), 2866(\mathrm{~m}), 2088(\mathrm{~m}), 1723(\mathrm{~s})$, 1461 (m), 1436 (w), 1285 (s), 1247 (s), 1127 (m), 853 (m), 741 (s); HRMS (ESI/QTOF) m/z: $[\mathrm{M}+\mathrm{Na}]^{+}$Calcd for $\mathrm{C}_{23} \mathrm{H}_{33} \mathrm{INaO}_{2} \mathrm{SSi}^{+}$551.0907; Found 551.0922.

\section{4-(((Triisopropylsilyl)ethynyl)thio)tetrahydrofuran-3-yl 2-iodobenzoate (8c)}

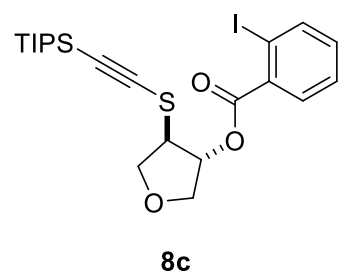

Synthesized following general procedure A starting from TIPS-EBX (6a) (86 mg, $0.20 \mathrm{mmol}$ ) and 3-oxa-6-thiabicyclo[3.1.0]hexane (7c) $(31 \mathrm{mg}, 0.30 \mathrm{mmol})$. The reaction was stirred at 70 
${ }^{\circ} \mathrm{C}$ for $48 \mathrm{~h}$. The crude oil was purified by column chromatography $\left(\mathrm{CH}_{2} \mathrm{Cl}_{2} / \mathrm{Pentane} ; 4: 6\right)$ to afford $8 c$ (64 mg, $0.12 \mathrm{mmol}, 61 \%)$ as a colorless oil. $\mathrm{R}_{\mathrm{f}} 0.55$ (AcOEt/Pentane; 1:9); ${ }^{1} \mathrm{H}$ NMR (400 MHz, Chloroform- $d$ ) $\delta 8.00$ (dd, $J=7.9,1.2 \mathrm{~Hz}, 1 \mathrm{H}, \mathrm{ArH}), 7.79$ (dd, $J=7.8,1.7 \mathrm{~Hz}, 1 \mathrm{H}$, $\operatorname{Ar} H), 7.41(\mathrm{td}, J=7.6,1.2 \mathrm{~Hz}, 1 \mathrm{H}, \operatorname{Ar} H), 7.17(\mathrm{td}, J=7.7,1.7 \mathrm{~Hz}, 1 \mathrm{H}, \operatorname{Ar} H), 5.59(\mathrm{dt}, J=4.4$, $1.9 \mathrm{~Hz}, 1 \mathrm{H}, \mathrm{OCH}), 4.37$ (dd, $\left.J=9.9,6.6 \mathrm{~Hz}, 1 \mathrm{H}, \mathrm{OCH}_{2} \mathrm{CHS}\right), 4.25$ (dd, $J=10.9,4.7 \mathrm{~Hz}, 1 \mathrm{H}$, $\left.\mathrm{OCH}_{2} \mathrm{CHO}\right), 4.07\left(\mathrm{dd}, J=10.9,1.8 \mathrm{~Hz}, 1 \mathrm{H}, \mathrm{OCH}_{2} \mathrm{CHO}\right), 3.91(\mathrm{dd}, J=9.9,5.0 \mathrm{~Hz}, 1 \mathrm{H}$, $\mathrm{OCH}_{2} \mathrm{CHS}$ ), 3.74 (ddd, $J=7.0,5.0,2.1 \mathrm{~Hz}, 1 \mathrm{H}, \mathrm{SCH}$ ), 1.07 (s, 21H, TIPS); ${ }^{13} \mathrm{C}$ NMR (100 MHz, Chloroform- $d$ ) $\delta 165.8,141.6,134.5,133.1,131.3,128.1,100.5,94.2,92.0,80.7,73.0$, 71.5, 50.3, 18.7, 11.4; IR ( $\left.v_{\max }, \mathrm{cm}^{-1}\right) 2864(\mathrm{~m}), 2090(\mathrm{~m}), 1738(\mathrm{w}), 1462(\mathrm{~m}), 1284(\mathrm{~m}), 1238$ (m), 1088 (s), 881 (m), 852 (s), 740 (s); HRMS (ESI/QTOF) m/z: [M + Na $]^{+}$Calcd for $\mathrm{C}_{22} \mathrm{H}_{31} \mathrm{INaO}_{3} \mathrm{SSi}^{+}$553.0700; Found 553.0713.

\section{Tert-butyl 3-((2-iodobenzoyl)oxy)-4-(((triisopropylsilyl)ethynyl)thio)pyrrolidine-1- carboxylate (8d)}

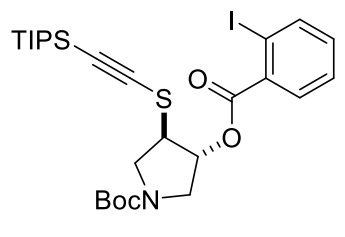

$8 d$

Synthesized following general procedure A starting from TIPS-EBX (6a) (86 mg, $0.20 \mathrm{mmol})$ and tert-butyl 6-thia-3-azabicyclo[3.1.0]hexane-3-carboxylate (7d) $(60 \mathrm{mg}, 0.30 \mathrm{mmol})$. The reaction was stirred at $70{ }^{\circ} \mathrm{C}$ for $48 \mathrm{~h}$. The crude oil was purified by column chromatography (AcOEt/Pentane; 5:95) to afford $\mathbf{8 d}\left(47 \mathrm{mg}, 0.075 \mathrm{mmol}, 38 \%\right.$ ) as an orange oil. $\mathrm{R}_{\mathrm{f}} 0.48$ (AcOEt/Pentane; 1:9); ${ }^{1} \mathrm{H}$ NMR (400 MHz, Chloroform- $d$ ) $\delta 7.98$ (d, $J=8.0 \mathrm{~Hz}, 1 \mathrm{H}, \mathrm{Ar} H$ ), $7.74(\mathrm{~d}, J=7.8 \mathrm{~Hz}, 1 \mathrm{H}, \operatorname{Ar} H), 7.41(\mathrm{t}, J=7.6 \mathrm{~Hz}, 1 \mathrm{H}, \operatorname{Ar} H), 7.17(\mathrm{t}, J=7.7 \mathrm{~Hz}, 1 \mathrm{H}, \operatorname{Ar} H), 5.57$ (d, $J=15.0 \mathrm{~Hz}, 1 \mathrm{H}, \mathrm{OCH}), 4.00\left(\mathrm{dd}, J=12.8,4.9 \mathrm{~Hz}, 1 \mathrm{H}, \mathrm{NCH}_{2}\right), 3.97-3.86\left(\mathrm{~m}, 1 \mathrm{H}, \mathrm{NCH}_{2}\right)$, $3.83-3.76(\mathrm{~m}, 1 \mathrm{H}, \mathrm{SCH}), 3.75-3.62\left(\mathrm{~m}, 1 \mathrm{H}, \mathrm{NCH}_{2}\right), 3.58\left(\mathrm{dd}, J=12.3,2.9 \mathrm{~Hz}, 1 \mathrm{H}, \mathrm{NCH}_{2}\right)$, 1.46 (s, 9H, C(CH3) 3 ), 1.08 (s, 21H, TIPS); ${ }^{13} \mathrm{C} \mathrm{NMR} \mathrm{(100} \mathrm{MHz,} \mathrm{Chloroform-} d$ ) mixture of rotamers: $\delta 165.6$ (two peaks), 154.2, 141.5 (two peaks), 134.8 (two peaks), 133.1 (two peaks), 131.3, 128.1, 101.0, 94.0, 91.7 (two peaks), 80.3, 78.1, 50.1 (two peaks), 49.3 (two peaks), 48.8 (two peaks), 28.6, 18.8, 11.4; IR ( $\left.v_{\max }, \mathrm{cm}^{-1}\right) 2971(\mathrm{w}), 2873(\mathrm{w}), 2093(\mathrm{w}), 1696(\mathrm{~s}), 1399$ (s), 
1238 (m), 1165 (s), 1116 (s), 877 (m), 858 (m), 738 (s); HRMS (ESI/QTOF) m/z: [M + $\mathrm{Na}]^{+}$Calcd for $\mathrm{C}_{27} \mathrm{H}_{40} \mathrm{INNaO}_{4} \mathrm{SSi}^{+}$652.1384; Found 652.1395.

2-(((Triisopropylsilyl)ethynyl)thio)ethyl 2-iodobenzoate (8e)

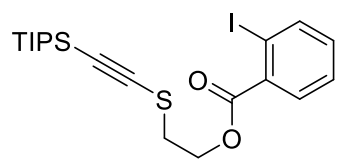

$8 \mathbf{e}$

Synthesized following general procedure A starting from TIPS-EBX (6a) (86 mg, $0.20 \mathrm{mmol})$ and ethylene sulfide $(\mathbf{7 e})(18 \mu \mathrm{L}, 0.30 \mathrm{mmol})$. The crude oil was purified by column chromatography ( $\mathrm{Et}_{2} \mathrm{O} /$ Pentane; 2:98) to afford $\mathbf{8 e}(45 \mathrm{mg}, 93 \mu \mathrm{mol}, 46 \%)$ as a light yellow oil. $\mathrm{R}_{\mathrm{f}} 0.38$ (Toluene/Pentane; 1:3); ${ }^{1} \mathrm{H}$ NMR (400 MHz, Chloroform- $d$ ) $\delta 8.00$ (dd, $J=8.0,1.2 \mathrm{~Hz}$, $1 \mathrm{H}, \operatorname{Ar} H), 7.85(\mathrm{dd}, J=7.8,1.7 \mathrm{~Hz}, 1 \mathrm{H}, \mathrm{Ar} H), 7.41(\mathrm{td}, J=7.6,1.2 \mathrm{~Hz}, 1 \mathrm{H}, \mathrm{Ar} H), 7.16(\mathrm{td}, J$ $=7.7,1.7 \mathrm{~Hz}, 1 \mathrm{H}, \mathrm{Ar} H), 4.64\left(\mathrm{t}, J=6.5 \mathrm{~Hz}, 2 \mathrm{H}, \mathrm{OCH}_{2}\right), 3.10\left(\mathrm{t}, J=6.5 \mathrm{~Hz}, 2 \mathrm{H}, \mathrm{SCH}_{2}\right), 1.07$ (s, 21H, TIPS); ${ }^{13} \mathrm{C}$ NMR (100 MHz, Chloroform- $d$ ) $\delta 166.2,141.5,134.8,133.0,131.3,128.1$, 98.5, 94.3, 94.1, 63.1, 34.2, 18.8, 11.4; IR ( $\left.v_{\max }, \mathrm{cm}^{-1}\right) 2946$ (m), 2866 (m), 2090 (m), 1729 (s), 1460 (m), 1433 (m), 1286 (s), 1245 (s), 1129 (m), 1008 (m), 854 (s), 741 (s); HRMS (ESI/QTOF) m/z: $[\mathrm{M}+\mathrm{H}]^{+}$Calcd for $\mathrm{C}_{20} \mathrm{H}_{30} \mathrm{IO}_{2} \mathrm{SSi}^{+}$489.0775; Found 489.0790.

1-(((Triisopropylsilyl)ethynyl)thio)propan-2-yl 2-iodobenzoate $\quad(8 f)$ and 2 (((Triisopropylsilyl)ethynyl)thio)propyl 2-iodobenzoate (8f')

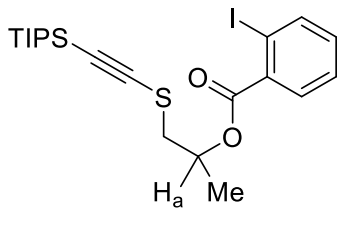

$8 f$

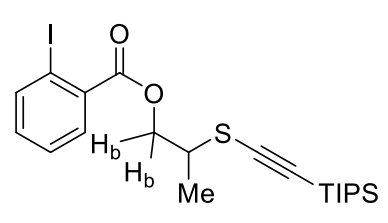

$8 f^{\prime}$

Synthesized following general procedure A starting from TIPS-EBX (6a) (86 mg, 0.20 mmol) and propylene sulfide (7f) $(24 \mu \mathrm{L}, 0.30 \mathrm{mmol})$. The crude oil was purified by column chromatography (Toluene/Pentane; 1:3) to afford an inseparable 2.1:1 mixture of $\mathbf{8 f} / \mathbf{8 f}$ ' (64 mg, $0.13 \mathrm{mmol}, 64 \%$ ) as a colorless oil (ratio was determined using the integrals of NMR signal for $\mathrm{H}_{\mathrm{a}}$ and $\mathrm{H}_{\mathrm{b}}$ ). $\mathrm{R}_{\mathrm{f}} 0.43$ (Toluene/Pentane; 1:3) 8f: ${ }^{1} \mathrm{H}$ NMR (400 MHz, Chloroform- $d$ ) $\delta 8.03-$ 7.95 (m, 1H, ArH), 7.80 (d, J=7.8 Hz, 1H, ArH), $7.44-7.36$ (m, 1H, ArH), 7.20 - 7.11 (m, $1 \mathrm{H}, \mathrm{Ar} H), 5.42(\mathrm{~h}, J=6.2 \mathrm{~Hz}, 1 \mathrm{H}, \mathrm{OCH}), 3.12\left(\mathrm{dd}, J=13.4,6.0 \mathrm{~Hz}, 1 \mathrm{H}, \mathrm{SCH}_{2}\right), 3.00(\mathrm{dd}, J=$ 
13.4, $\left.6.1 \mathrm{~Hz}, 1 \mathrm{H}, \mathrm{SCH}_{2}\right), 1.55\left(\mathrm{~d}, J=6.5 \mathrm{~Hz}, 3 \mathrm{H}, \mathrm{CH}_{3} \mathrm{CH}\right), 1.11-1.03(\mathrm{~m}, 21 \mathrm{H}, \mathrm{TIPS}) ;{ }^{13} \mathrm{C}$ NMR (100 MHz, Chloroform-d) $\delta$ 165.8, 141.4, 135.4, 132.7, 131.1, 128.1, 97.7, 95.1, 94.1, 71.1, 41.2, 19.2, 18.8, 11.4; 8f': ${ }^{1} \mathrm{H}$ NMR (400 MHz, Chloroform- $d$ ) $\delta 8.03-7.95$ (m, 1H, $\operatorname{Ar} H), 7.85(\mathrm{~d}, J=7.8 \mathrm{~Hz}, 1 \mathrm{H}, \operatorname{Ar} H), 7.45-7.36(\mathrm{~m}, 1 \mathrm{H}, \operatorname{Ar} H), 7.20-7.11(\mathrm{~m}, 1 \mathrm{H}, \operatorname{Ar} H), 4.52$ (dd, $\left.J=11.3,6.7 \mathrm{~Hz}, 1 \mathrm{H}, \mathrm{OCH}_{2}\right), 4.43$ (dd, $\left.J=11.3,6.6 \mathrm{~Hz}, 1 \mathrm{H}, \mathrm{OCH}_{2}\right), 3.32(\mathrm{~h}, J=6.8 \mathrm{~Hz}$, $1 \mathrm{H}, \mathrm{SCH}), 1.51\left(\mathrm{~d}, J=6.9 \mathrm{~Hz}, 3 \mathrm{H}, \mathrm{CH}_{3} \mathrm{CH}\right), 1.14-1.01$ (m, 21H, TIPS); ${ }^{13} \mathrm{C}$ NMR $(100 \mathrm{MHz}$, Chloroform- $d$ ) $\delta 166.2,141.5,134.9,133.0,131.3,128.1,100.4,94.3,92.3,67.7,41.9,18.8$, 17.7, 11.5; IR ( $\left.v_{\max }, \mathrm{cm}^{-1}\right) 2952$ (s), 2867 (s), 2090 (s), 1736 (s), 1463 (m), 1281 (s), 1242 (s), 1123 (s), 1021 (m), 878 (s), 856 (s), 741 (s), 675 (s); HRMS (ESI/QTOF) m/z: [M + H] ${ }^{+}$Calcd for $\mathrm{C}_{21} \mathrm{H}_{32} \mathrm{IO}_{2} \mathrm{SSi}^{+}$503.0932; Found 503.0938.

\section{1-(((Triisopropylsilyl)ethynyl)thio)octan-2-yl $\quad$ 2-iodobenzoate $\quad(8 g) \quad$ and $\quad 2$ - (((Triisopropylsilyl)ethynyl)thio)octyl 2-iodobenzoate $\left(8 \mathrm{~g}^{\prime}\right)$}

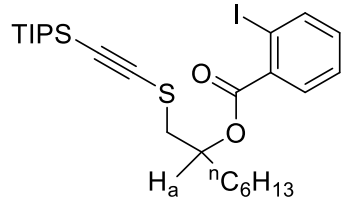

89

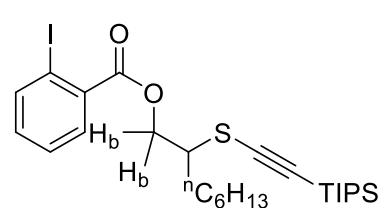

$8 \mathbf{g}^{\prime}$

Synthesized following general procedure A starting from TIPS-EBX (6a) (86 mg, $0.20 \mathrm{mmol})$ and 2-hexylthiirane $(\mathbf{7 g})(43 \mathrm{mg}, 0.30 \mathrm{mmol})$. The crude oil was purified by column chromatography (Toluene/Pentane; 15:85) to afford an inseparable 1.9:1 mixture of $\mathbf{8 g} / \mathbf{8 g}$ ' (68 $\mathrm{mg}, 0.12 \mathrm{mmol}, 60 \%$ ) as a colorless oil (ratio was determined using the integrals of NMR signal for $\mathrm{H}_{\mathrm{a}}$ and $\mathrm{H}_{\mathrm{b}}$ ). $\mathrm{R}_{\mathrm{f}} 0.55$ (Toluene/Pentane; 1:3); 8g: ${ }^{1} \mathrm{H}$ NMR (400 MHz, Chloroform- $d$ ) $\delta 8.03$ -7.95 (m, 1H, ArH), 7.80 (dd, $J=7.8,1.8 \mathrm{~Hz}, 1 \mathrm{H}, \operatorname{Ar} H), 7.45-7.37$ (m, 1H, ArH), 7.20 - 7.11 $(\mathrm{m}, 1 \mathrm{H}, \mathrm{Ar} H), 5.42-5.33(\mathrm{~m}, 1 \mathrm{H}, \mathrm{OCH}), 3.08$ (d, J = 5.9 Hz, 2H, $\left.\mathrm{SCH}_{2}\right), 1.96-1.73(\mathrm{~m}, 2 \mathrm{H}$, $\mathrm{CH}_{2}$ hexyl), $1.53-1.22$ (m, 8H, $\mathrm{CH}_{2}$ hexyl), $1.10-1.03$ (m, 21H, TIPS), 0.88 (t, $J=6.5 \mathrm{~Hz}$, $\left.3 \mathrm{H}, \mathrm{CH}_{2} \mathrm{CH}_{3}\right) ;{ }^{13} \mathrm{C}$ NMR (100 MHz, Chloroform- $d$ ) $\delta$ 165.9, 141.3, 135.5, 132.7, 131.0, 128.0, 97.5, 95.3, 94.1, 74.2, 39.9, 33.1, 31.8, 29.2, 25.5, 22.7, 18.8, 14.2, 11.4; 8g': ${ }^{1} \mathrm{H}$ NMR (400 MHz, Chloroform- $d$ ) $\delta 8.02-7.96(\mathrm{~m}, 1 \mathrm{H}, \mathrm{ArH}), 7.85(\mathrm{dd}, J=7.8,1.7 \mathrm{~Hz}, 1 \mathrm{H}, \mathrm{ArH}), 7.45-$ $7.37(\mathrm{~m}, 1 \mathrm{H}, \mathrm{ArH}), 7.20-7.10(\mathrm{~m}, 1 \mathrm{H}, \mathrm{ArH}), 4.51$ (qd, $\left.J=11.4,6.6 \mathrm{~Hz}, 2 \mathrm{H}, \mathrm{OCH}_{2}\right), 3.16-$ $3.10(\mathrm{~m}, 1 \mathrm{H}, \mathrm{SCH}), 1.95-1.73\left(\mathrm{~m}, 2 \mathrm{H}, \mathrm{CH}_{2}\right.$ hexyl), $1.51-1.22\left(\mathrm{~m}, 8 \mathrm{H}, \mathrm{CH}_{2}\right.$ hexyl), $1.12-$ $1.03\left(\mathrm{~m}, 21 \mathrm{H}\right.$, TIPS), $0.92-0.85\left(\mathrm{~m}, 3 \mathrm{H}, \mathrm{CH}_{2} \mathrm{CH}_{3}\right) ;{ }^{13} \mathrm{C}$ NMR (100 MHz, Chloroform- $d$ ) $\delta$ 166.2, 141.5, 134.9, 132.9, 131.3, 128.1, 99.7, 94.3, 92.3, 66.8, 47.6, 31.8, 30.8, 29.1, 26.8, 
22.7, 18.8, 14.2, 11.5; IR ( $\left.v_{\max }, \mathrm{cm}^{-1}\right) 2933(\mathrm{~m}), 2862(\mathrm{~m}), 2089(\mathrm{~m}), 1730(\mathrm{~s}), 1461(\mathrm{~m}), 1281$ (s), 1245 (s), 1126 (m), 1101 (m), 1009 (m), 856 (m), 739 (s); HRMS (ESI/QTOF) m/z: [M + $\mathrm{H}]^{+}$Calcd for $\mathrm{C}_{26} \mathrm{H}_{42} \mathrm{IO}_{2} \mathrm{SSi}^{+}$573.1714; Found 573.1724.

2-Methyl-1-(((triisopropylsilyl)ethynyl)thio)propan-2-yl 2-iodobenzoate $(8 \mathrm{~h})$ and 2Methyl-2-(((triisopropylsilyl)ethynyl)thio)propyl 2-iodobenzoate (8h')

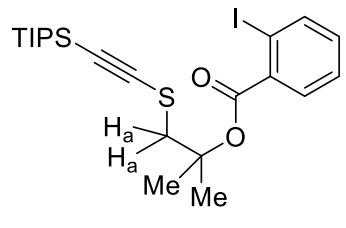

$8 \mathrm{~h}$

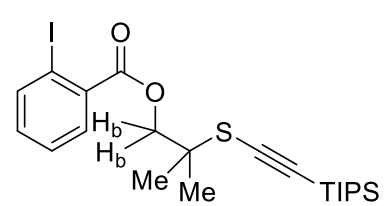

$8 h^{\prime}$

Synthesized following general procedure A starting from TIPS-EBX (6a) (86 mg, $0.20 \mathrm{mmol})$ and isobutylene sulfide $(7 \mathbf{h})(27 \mathrm{mg}, 0.30 \mathrm{mmol})$. The reaction was stirred at $50{ }^{\circ} \mathrm{C}$ for $48 \mathrm{~h}$. The crude oil was purified by column chromatography (Toluene/Pentane; 1:3) to afford an inseparable 15.5:1 mixture of $\mathbf{8 h} / \mathbf{8 h}$ ' (41 $\mathrm{mg}, 0.080 \mathrm{mmol}, 40 \%$ ) as a colorless oil (ratio was determined using the integrals of NMR signal for $\mathrm{H}_{\mathrm{a}}$ and $\mathrm{H}_{\mathrm{b}}$ ). $\mathrm{R}_{\mathrm{f}} 0.43$ (Toluene/Pentane; 1:3); 8h: ${ }^{1} \mathrm{H}$ NMR (400 MHz, Chloroform- $d$ ) $\delta 7.95$ (dd, $J=8.0,1.2 \mathrm{~Hz}, 1 \mathrm{H}, \mathrm{Ar} H$ ), 7.75 (dd, $J=7.7$, $1.8 \mathrm{~Hz}, 1 \mathrm{H}, \operatorname{Ar} H), 7.39(\mathrm{td}, J=7.6,1.2 \mathrm{~Hz}, 1 \mathrm{H}, \operatorname{Ar} H), 7.12(\mathrm{td}, J=7.6,1.7 \mathrm{~Hz}, 1 \mathrm{H}, \operatorname{Ar} H), 3.39$ $\left(\mathrm{s}, 2 \mathrm{H}, \mathrm{SCH}_{2}\right), 1.75$ (s, 6H, $\left.\mathrm{CCH}_{3}\right), 1.15-0.98$ (m, 21H, TIPS); ${ }^{13} \mathrm{C}$ NMR (100 MHz, Chloroform- $d$ ) $\delta 165.8,141.1,136.4,132.3,130.9,127.9,96.6,96.5,93.6,83.8,46.5,25.6$, 18.6, 11.3; 8h': ${ }^{1} \mathrm{H}$ NMR (400 MHz, Chloroform- $d$ ) $\delta 8.00(\mathrm{dd}, J=7.9,1.2 \mathrm{~Hz}, 1 \mathrm{H}, \operatorname{Ar} H), 7.85$ (dd, $J=7.8,1.7 \mathrm{~Hz}, 1 \mathrm{H}, \operatorname{Ar} H), 7.45-7.41(\mathrm{~m}, 1 \mathrm{H}, \operatorname{Ar} H), 7.20-7.16(\mathrm{~m}, 1 \mathrm{H}, \operatorname{Ar} H), 4.40$ (s, $\left.2 \mathrm{H}, \mathrm{OCH}_{2}\right), 1.50\left(\mathrm{~s}, 6 \mathrm{H}, \mathrm{CCH}_{3}\right), 1.11-1.00$ (m, 21H, TIPS); ${ }^{13} \mathrm{C}$ NMR spectrum was not resolved due the too small signals intensities; IR $\left(v_{\max }, \mathrm{cm}^{-1}\right) 2945(\mathrm{~s}), 2866(\mathrm{~s}), 2089(\mathrm{~m}), 1722$ (s), 1462 (m), 1377 (m), 1297 (s), 1252 (s), 1208 (m), 1105 (s), 1009 (m), 874 (s), 859 (s), 742 (s); HRMS (ESI/QTOF) m/z: $[\mathrm{M}+\mathrm{Na}]^{+}$Calcd for $\mathrm{C}_{22} \mathrm{H}_{33} \mathrm{INaO}_{2} \mathrm{SSi}^{+}$539.0907; Found 539.0907.

(S)-1-(((Triisopropylsilyl)ethynyl)thio)-3-((triisopropylsilyl)oxy)propyl 2-iodobenzoate (8i) and (S)-2-(((triisopropylsilyl)ethynyl)thio)-3-((triisopropylsilyl)oxy)propyl 2iodobenzoate ( $\left(8 \mathbf{i}^{\prime}\right)$ 

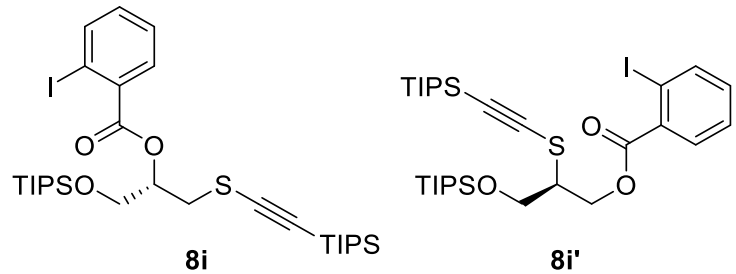

Synthesized following general procedure A starting from TIPS-EBX (6a) (86 mg, $0.20 \mathrm{mmol})$ and $(R)$-triisopropyl(thiiran-2-ylmethoxy)silane (7i) $(74 \mathrm{mg}, 0.30 \mathrm{mmol})$. The reaction was stirred at $50{ }^{\circ} \mathrm{C}$ for $48 \mathrm{~h}$. The crude oil was purified by column chromatography $\left(\mathrm{CH}_{2} \mathrm{Cl}_{2} /\right.$ Pentane; $\left.1: 9\right)$ to afford $\mathbf{8 i}(21 \mathrm{mg}, 0.032 \mathrm{mmol}, 16 \%)$ and $\mathbf{8 i}$ ' (48 $\mathrm{mg}, 0.071 \mathrm{mmol}$, 36\%). 8i: $\mathrm{R}_{\mathrm{f}} 0.21\left(\mathrm{CH}_{2} \mathrm{Cl}_{2} /\right.$ Pentane; 1:9); ${ }^{1} \mathrm{H}$ NMR (400 MHz, Chloroform- $d$ ) $\delta 7.99$ (dd, $J=$ 7.9, $1.2 \mathrm{~Hz}, 1 \mathrm{H}, \operatorname{Ar} H), 7.84(\mathrm{dd}, J=7.8,1.7 \mathrm{~Hz}, 1 \mathrm{H}, \operatorname{Ar} H), 7.39(\mathrm{td}, J=7.6,1.2 \mathrm{~Hz}, 1 \mathrm{H}, \operatorname{Ar} H)$, $7.14(\mathrm{td}, J=7.7,1.8 \mathrm{~Hz}, 1 \mathrm{H}, \operatorname{Ar} H), 5.43-5.34(\mathrm{~m}, 1 \mathrm{H}, \mathrm{OCH}), 4.06(\mathrm{dd}, J=4.4,2.1 \mathrm{~Hz}, 2 \mathrm{H}$, TIPSO-CH ), 3.25 (dd, $J=13.4,5.8 \mathrm{~Hz}, 1 \mathrm{H}, \mathrm{SCH}$ ), $3.16(\mathrm{dd}, J=13.4,6.8 \mathrm{~Hz}, 1 \mathrm{H}, \mathrm{SCH}), 1.16$ -0.98 (m, 42H, TIPS); ${ }^{13} \mathrm{C}$ NMR (100 MHz, Chloroform- $d$ ) $\delta 165.7,141.4,135.1,132.8,131.3$, 128.0, 97.7, 95.0, 94.3, 74.2, 63.1, 36.6, 18.8, 18.1, 12.0, 11.4; IR ( $\left.v_{\max }, \mathrm{cm}^{-1}\right) 2950$ (m), 2867 (m), 2095 (m), 1737 (m), 1463 (m), 1244 (m), 1122 (s), 1006 (s), 881 (s), 788 (m), 737 (s), 675 (s); HRMS (ESI/QTOF) m/z: $[\mathrm{M}+\mathrm{Na}]^{+}$Calcd for $\mathrm{C}_{30} \mathrm{H}_{51} \mathrm{INaO}_{3} \mathrm{SSi}_{2}{ }^{+}$697.2034; Found 697.2048. Chiral HPLC conditions: ee > 95\% ; Chiralpak IC 99.95:0.05 Hexane/iPrOH, 1.0 $\mathrm{mL} / \mathrm{min}, 60 \mathrm{~min} . \mathrm{tr}=9.2 \mathrm{~min}, \lambda=230.4 \mathrm{~cm}^{-1}$. The stereochemistry drawn is based on the assumption that the reaction proceed under inversion of configuration. 8i': $R_{f} 0.18$ $\left(\mathrm{CH}_{2} \mathrm{Cl}_{2} /\right.$ Pentane; $\left.1: 9\right) ;{ }^{1} \mathrm{H}$ NMR (400 MHz, Chloroform- $d$ ) $\delta 8.00(\mathrm{dd}, J=8.0,1.2 \mathrm{~Hz}, 1 \mathrm{H}$, $\operatorname{Ar} H), 7.84(\mathrm{dd}, J=7.8,1.7 \mathrm{~Hz}, 1 \mathrm{H}, \operatorname{Ar} H), 7.41(\mathrm{td}, J=7.6,1.2 \mathrm{~Hz}, 1 \mathrm{H}, \operatorname{Ar} H), 7.16(\mathrm{td}, J=7.6$, $1.7 \mathrm{~Hz}, 1 \mathrm{H}, \mathrm{Ar} H), 4.71\left(\mathrm{dd}, J=11.5,5.7 \mathrm{~Hz}, 1 \mathrm{H}, \mathrm{OCH}_{2}\right), 4.60\left(\mathrm{dd}, J=11.5,6.8 \mathrm{~Hz}, 1 \mathrm{H}, \mathrm{OCH}_{2}\right)$, $4.12\left(\mathrm{dd}, J=10.3,5.0 \mathrm{~Hz}, 1 \mathrm{H}\right.$, TIPSO-CH$\left.H_{2}\right), 4.01\left(\mathrm{dd}, J=10.3,7.2 \mathrm{~Hz}, 1 \mathrm{H}\right.$, TIPSO-CH$\left.H_{2}\right), 3.45$ - 3.32 (m, 1H, SCH), $1.17-0.98$ (m, 42H, TIPS); ${ }^{13} \mathrm{C}$ NMR (100 MHz, Chloroform- $d$ ) $\delta 166.1$, 141.5, 134.9, 132.9, 131.3, 128.1, 99.3, 94.3, 92.9, 64.0, 63.1, 49.6, 18.8, 18.1, 12.0, 11.5; IR $\left(v_{\max }, \mathrm{cm}^{-1}\right) 2933(\mathrm{~s}), 2864(\mathrm{~s}), 2091(\mathrm{~m}), 1738(\mathrm{~s}), 1463(\mathrm{~m}), 1286(\mathrm{~s}), 1243(\mathrm{~s}), 1189(\mathrm{~m}), 1127$ (s), 1099 (s), 885 (m), 741 (s), 682 (s); HRMS (ESI/QTOF) m/z: [M + Na $]^{+}$Calcd for $\mathrm{C}_{30} \mathrm{H}_{51} \mathrm{INaO}_{3} \mathrm{SSi}_{2}{ }^{+}$697.2034; Found 697.2048. Chiral HPLC conditions: ee > 95\% ; Chiralpak IBN 100:0 Hexane/iPrOH, $1.0 \mathrm{~mL} / \mathrm{min}, 60 \mathrm{~min} . \mathrm{tr}=15.9 \mathrm{~min}, \lambda=230.4 \mathrm{~cm}^{-1}$.

\section{1,4-Bis(benzyloxy)-3-(((triisopropylsilyl)ethynyl)thio)butan-2-yl 2-iodobenzoate (8j)}




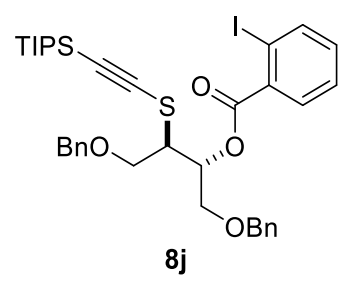

Synthesized following general procedure A starting from TIPS-EBX (6a) (86 mg, 0.20 mmol) and 2,3-bis((benzyloxy)methyl)thiirane (7j) $(90 \mathrm{mg}, 0.30 \mathrm{mmol})$. The reaction was stirred at 70 ${ }^{\circ} \mathrm{C}$ for $48 \mathrm{~h}$. The crude oil was purified by column chromatography $\left(\mathrm{CH}_{2} \mathrm{Cl}_{2} / \mathrm{Pentane} ; 1: 1\right)$ to afford $8 \mathbf{j}$ (56 mg, $0.077 \mathrm{mmol}, 38 \%$ ) as a colorless oil. $\mathrm{R}_{\mathrm{f}} 0.55$ (AcOEt/Pentane; 1:9); ${ }^{1} \mathrm{H}$ NMR (400 MHz, Chloroform- $d$ ) $\delta 7.99$ (dd, $J=7.9,1.2 \mathrm{~Hz}, 1 \mathrm{H}, \mathrm{ArH}), 7.79$ (dd, $J=7.8,1.7 \mathrm{~Hz}, 1 \mathrm{H}$, $\operatorname{Ar} H), 7.39-7.21(\mathrm{~m}, 11 \mathrm{H}, \operatorname{Ar} H), 7.14(\mathrm{td}, J=7.7,1.7 \mathrm{~Hz}, 1 \mathrm{H}, \operatorname{Ar} H), 5.76(\mathrm{q}, J=5.1 \mathrm{~Hz}, 1 \mathrm{H}$, $\mathrm{OCH}), 4.64-4.49\left(\mathrm{~m}, 4 \mathrm{H}, \mathrm{PhCH}_{2} \mathrm{O}\right), 3.93-3.76\left(\mathrm{~m}, 4 \mathrm{H}, \mathrm{OCH}_{2} \mathrm{CH}\right), 3.69-3.60(\mathrm{~m}, 1 \mathrm{H}, \mathrm{SCH})$, 1.04 (m, 21H, TIPS); ${ }^{13} \mathrm{C}$ NMR (100 MHz, Chloroform- $d$ ) $\delta 165.4,141.4,137.9,137.8,134.7$, 132.9, 131.5, 128.5, 128.5, 128.0, 128.0, 127.9, 127.8, 127.8, 98.8, 94.5, 93.8, 73.7, 73.4, 72.1, 69.2, 69.0, 50.5, 18.8, 11.5; IR ( $\left.v_{\max }, \mathrm{cm}^{-1}\right) 2864(\mathrm{~m}), 2359(\mathrm{~m}), 2089(\mathrm{~m}), 1740(\mathrm{~m}), 1456(\mathrm{~m})$, 1238 (m), 1089 (s), 882 (m), 854 (m), 736 (s), 697 (s), 678 (s); HRMS (ESI/QTOF) m/z: [M + $\mathrm{H}]^{+}$Calcd for $\mathrm{C}_{36} \mathrm{H}_{46} \mathrm{IO}_{4} \mathrm{SSi}^{+}$729.1925; Found 729.1930.

\section{2-((Phenylethynyl)thio)cyclohexyl 2-iodobenzoate (8k)}

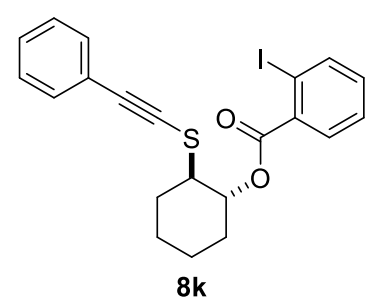

Synthesized following general procedure A starting from 1-[Phenylethynyl]-1,2-benziodoxol$3(1 \mathrm{H})$-one $(\mathbf{6 k})(70 \mathrm{mg}, 0.20 \mathrm{mmol})$ and cyclohexene sulfide $(\mathbf{7 a})(33 \mu \mathrm{L}, 0.30 \mathrm{mmol})$. The reaction was stirred for $1.5 \mathrm{~h}$. The crude oil was purified by column chromatography (Toluene/Pentane; $1: 1$ ) to afford $\mathbf{8 k}$ (46 $\mathrm{mg}, 0.10 \mathrm{mmol}, 50 \%$ ) as an orange oil; $\mathrm{R}_{\mathrm{f}} 0.47$ (Toluene/Pentane; 1:1) ${ }^{1} \mathrm{H}$ NMR (400 MHz, Chloroform- $d$ ) $\delta 7.97$ (dd, $J=8.0,1.2 \mathrm{~Hz}, 1 \mathrm{H}$, $\operatorname{Ar} H), 7.90(\mathrm{dd}, J=7.8,1.7 \mathrm{~Hz}, 1 \mathrm{H}, \operatorname{Ar} H), 7.44-7.38(\mathrm{~m}, 2 \mathrm{H}, \operatorname{Ar} H), 7.34(\mathrm{td}, J=7.6,1.2 \mathrm{~Hz}$, $1 \mathrm{H}, \operatorname{Ar} H), 7.30-7.25(\mathrm{~m}, 3 \mathrm{H}, \operatorname{Ar} H), 7.12(\mathrm{td}, J=7.7,1.7 \mathrm{~Hz}, 1 \mathrm{H}, \operatorname{Ar} H), 5.14(\mathrm{td}, J=10.0,4.4$ $\mathrm{Hz}, 1 \mathrm{H}, \mathrm{OCH}), 3.08$ (ddd, $J=11.3,9.8,4.2 \mathrm{~Hz}, 1 \mathrm{H}, \mathrm{CHS}), 2.42-2.28$ (m, 2H, CH $\mathrm{H}_{2}$ cyclohexyl), 
$1.90-1.76$ (m, 2H, $\mathrm{CH}_{2}$ cyclohexyl), $1.64-1.33$ (m, 4H, $\mathrm{CH}_{2}$ cyclohexyl); ${ }^{13} \mathrm{C}$ NMR (100 MHz, Chloroform-d) $\delta 165.8,141.3,135.5,132.6,131.8,131.1,128.4,128.2,128.0,123.5$, 95.3, 94.2, 76.8, 75.5, 51.1, 32.2, 32.0, 25.6, 24.0; IR ( $\left.v_{\max }, \mathrm{cm}^{-1}\right) 3060(\mathrm{w}), 2931(\mathrm{~m}), 2855$ (w), 2164 (w), 1725 (s), 1587 (w), 1440 (m), 1281 (s), 1250 (s), 1131 (m), 1100 (m), 1015 (s), 746 (s), 693 (m); HRMS (ESI/QTOF) m/z: $[\mathrm{M}+\mathrm{Na}]^{+}$Calcd for $\mathrm{C}_{21} \mathrm{H}_{19} \mathrm{INaO}_{2} \mathrm{~S}^{+} 485.0043$; Found 485.0057.

\section{2-((p-Tolylethynyl)thio)cyclohexyl 2-iodobenzoate (81)}

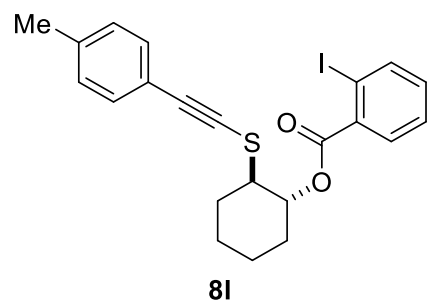

Synthesized following general procedure A starting from 1-( $p$-Tolylethynyl)-1,2benziodoxol-3(1H)-one (6l) (72 mg, $0.20 \mathrm{mmol}, 1.0$ equiv.) and cyclohexene sulfide (7a) (33 $\mu \mathrm{L}, 0.30 \mathrm{mmol})$. The reaction was stirred at $50^{\circ} \mathrm{C}$ for $2 \mathrm{~h}$. The crude oil was purified by column chromatography (Toluene/Pentane; 35:65) to afford $\mathbf{8 1}$ (48 $\mathrm{mg}, 0.10 \mathrm{mmol}, 50 \%)$ as a yellow oil. $\mathrm{R}_{\mathrm{f}} 0.5$ (Toluene/Pentane; 1:1); ${ }^{1} \mathrm{H}$ NMR (400 MHz, Chloroform- $d$ ) $\delta 7.97$ (dd, $J=8.0,1.2$ Hz, 1H, ArH), 7.90 (dd, J= 7.8, $1.7 \mathrm{~Hz}, 1 \mathrm{H}, \operatorname{Ar} H), 7.40-7.28$ (m, 3H, ArH), $7.16-7.05$ (m, $3 \mathrm{H}, \mathrm{ArH}), 5.13(\mathrm{td}, J=10.0,4.4 \mathrm{~Hz}, 1 \mathrm{H}, \mathrm{OCH}), 3.12-3.02(\mathrm{~m}, 1 \mathrm{H}, \mathrm{SCH}), 2.42-2.28(\mathrm{~m}, 5 \mathrm{H}$, $\mathrm{CH}_{2}$ cyclohexyl $\left.+\mathrm{PhCH}_{3}\right), 1.88-1.78\left(\mathrm{~m}, 3 \mathrm{H}, \mathrm{CH}_{2}\right.$ cyclohexyl), $1.64-1.32\left(\mathrm{~m}, 3 \mathrm{H}, \mathrm{CH}_{2}\right.$ cyclohexyl); ${ }^{13} \mathrm{C}$ NMR (100 MHz, Chloroform- $d$ ) $\delta 165.8,141.3,138.5,135.5,132.6,131.8$, 131.1, 129.1, 128.0, 120.4, 95.4, 94.2, 75.8, 75.5, 51.1, 32.2, 32.0, 25.6, 24.0, 21.6; IR ( $v_{\max }$, $\left.\mathrm{cm}^{-1}\right) 3031(\mathrm{w}), 2931(\mathrm{w}), 2165$ (w), 1723 (s), 1575 (w), 1509 (w), 1440 (m), 1281 (s), 1249 (s), 1131 (m), 1100 (s), 1014 (s), 945 (m), 818 (s), 741 (s); HRMS (ESI/QTOF) m/z: [M + $\mathrm{Na}]^{+}$Calcd for $\mathrm{C}_{22} \mathrm{H}_{21} \mathrm{INaO}_{2} \mathrm{~S}^{+}$499.0199; Found 499.0201.

\section{2-(((2-Bromophenyl)ethynyl)thio)cyclohexyl 2-iodobenzoate (8m)}




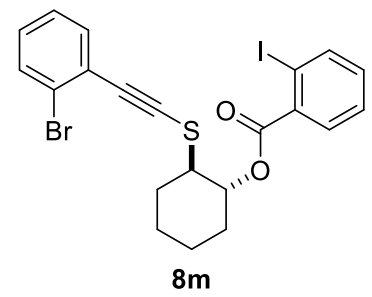

Synthesized following general procedure A starting from 1-[2-Bromophenylethynyl]-1,2benziodoxol-3(1H)-one (6m) (85 mg, $0.20 \mathrm{mmol}, 1.0$ equiv.) and cyclohexene sulfide (7a) (33 $\mu \mathrm{L}, 0.30 \mathrm{mmol})$. The reaction was stirred at $50^{\circ} \mathrm{C}$ for $2 \mathrm{~h}$. The crude oil was purified by column chromatography (Toluene/Pentane; 1:1) to afford $\mathbf{8 m}(59 \mathrm{mg}, 0.11 \mathrm{mmol}, 54 \%)$ as a yellow oil. $\mathrm{R}_{\mathrm{f}} 0.47$ (Toluene/Pentane; 1:1); ${ }^{1} \mathrm{H}$ NMR (400 MHz, Chloroform- $d$ ) $\delta 7.96$ (dd, $J=7.9,1.2 \mathrm{~Hz}$, $1 \mathrm{H}, \operatorname{Ar} H), 7.89$ (dd, $J=7.8,1.7 \mathrm{~Hz}, 1 \mathrm{H}, \operatorname{Ar} H), 7.54$ (dd, $J=8.0,1.2 \mathrm{~Hz}, 1 \mathrm{H}, \operatorname{Ar} H), 7.40$ (dd, $J$ $=7.7,1.7 \mathrm{~Hz}, 1 \mathrm{H}, \operatorname{Ar} H), 7.35(\mathrm{td}, J=7.6,1.2 \mathrm{~Hz}, 1 \mathrm{H}, \operatorname{Ar} H), 7.22(\mathrm{td}, J=7.6,1.2 \mathrm{~Hz}, 1 \mathrm{H}, \operatorname{Ar} H)$, 7.12 (tt, $J=7.6,1.7 \mathrm{~Hz}, 2 \mathrm{H}, \mathrm{ArH}), 5.19$ (td, $J=10.0,4.5 \mathrm{~Hz}, 1 \mathrm{H}, \mathrm{OCH}), 3.12$ (ddd, $J=11.6$, 9.9, $4.2 \mathrm{~Hz}, 1 \mathrm{H}, \mathrm{SCH}), 2.39$ (m, 2H, $\mathrm{CH}_{2}$ cyclohexyl), $2.03-1.89$ (m, 1H, $\mathrm{CH}_{2}$ cyclohexyl), $1.89-1.79$ (m, 2H, $\mathrm{CH}_{2}$ cyclohexyl), $1.64-1.32$ (m, 3H, $\mathrm{CH}_{2}$ cyclohexyl); ${ }^{13} \mathrm{C}$ NMR (100 MHz, Chloroform-d) $\delta 165.8,141.3,135.5,133.1,132.6,132.4,131.2,129.0,128.0,127.1$, 125.7, 125.1, 94.2, 94.0, 82.4, 75.5, 51.3, 32.3, 32.0, 25.7, 24.0; IR ( $\left.v_{\max }, \mathrm{cm}^{-1}\right) 3060(\mathrm{w}), 2925$ (w), 2167 (m), 1724 (s), 1577 (w), 1460 (m), 1428 (m), 1251 (s), 1129 (m), 1099 (m), 1017 (s), 943 (m), 743 (s); HRMS (ESI/QTOF) m/z: [M + Na] ${ }^{+}$Calcd for $\mathrm{C}_{21} \mathrm{H}_{18} \mathrm{BrINaO}_{2} \mathrm{~S}^{+}$562.9148; Found 562.9151.

\section{2-((3,3-Dimethylbut-1-yn-1-yl)thio)cyclohexyl 2-iodobenzoate (8n)}

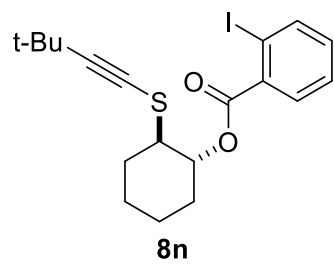

Synthesized following general procedure A starting from 1-[3,3-Dimethylbutynyl]-1,2benziodoxol-3(1H)-one (6n) $(66 \mathrm{mg}, 0.20 \mathrm{mmol})$ and cyclohexene sulfide (7a) $(33 \mu \mathrm{L}, 0.30$ mmol). The reaction was stirred at $50{ }^{\circ} \mathrm{C}$ for $4.5 \mathrm{~h}$. The crude oil was purified by column chromatography $\left(\mathrm{CH}_{2} \mathrm{Cl}_{2} /\right.$ Pentane; 3:7) to afford $8 \mathbf{n}(47 \mathrm{mg}, 0.11 \mathrm{mmol}, 53 \%)$ as a colorless oil. $\mathrm{R}_{\mathrm{f}} 0.38$ (Toluene/Pentane; 1:3); ${ }^{1} \mathrm{H}$ NMR (400 MHz, Chloroform- $d$ ) $\delta 7.97$ (dd, $J=8.0,1.2$ 
$\mathrm{Hz}, 1 \mathrm{H}, \mathrm{ArH}), 7.87(\mathrm{dd}, J=7.8,1.7 \mathrm{~Hz}, 1 \mathrm{H}, \mathrm{ArH}), 7.40(\mathrm{td}, J=7.6,1.2 \mathrm{~Hz}, 1 \mathrm{H}, \mathrm{ArH}), 7.14$ (td, $J=7.6,1.7 \mathrm{~Hz}, 1 \mathrm{H}, \mathrm{Ar} H), 5.03(\mathrm{td}, J=9.9,4.4 \mathrm{~Hz}, 1 \mathrm{H}, \mathrm{OCH}), 2.90(\mathrm{ddd}, J=11.2,9.8,4.2 \mathrm{~Hz}$, $1 \mathrm{H}, \mathrm{SCH}), 2.41-2.30$ (m, 1H, $\mathrm{CH}_{2}$ cyclohexyl), $2.29-2.19$ (m, 1H, $\mathrm{CH}_{2}$ cyclohexyl), $1.88-$ $1.69\left(\mathrm{~m}, 3 \mathrm{H}, \mathrm{CH}_{2}\right.$ cyclohexyl), $1.61-1.31$ (m, 3H, $\mathrm{CH}_{2}$ cyclohexyl), $1.23\left(\mathrm{~s}, 9 \mathrm{H}, \mathrm{C}\left(\mathrm{CH}_{3}\right)_{3}\right) ;{ }^{13} \mathrm{C}$ NMR (100 MHz, Chloroform-d) $\delta$ 165.8, 141.2, 135.8, 132.6, 131.1, 128.0, 105.0, 94.1, 75.1, 64.0, 50.1, 32.0, 31.8, 31.1, 29.0, 25.5, 24.0; IR ( $\left.v_{\max }, \mathrm{cm}^{-1}\right) 2975(\mathrm{w}), 1723(\mathrm{~m}), 1442(\mathrm{w}), 1251$ (s), 1097 (m), 1014 (m), 944 (m), 737 (s); HRMS (ESI/QTOF) m/z: [M + Na $]^{+}$Calcd for $\mathrm{C}_{19} \mathrm{H}_{23} \mathrm{INaO}_{2} \mathrm{~S}^{+}$465.0356; Found 465.0345.

\section{2-((Cyclopropylethynyl)thio)cyclohexyl 2-iodobenzoate (80)}

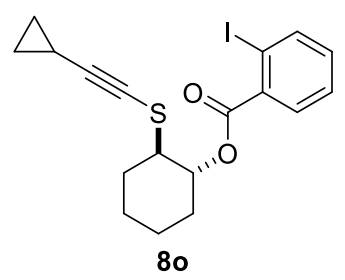

Synthesized following general procedure A starting from 2-Cyclopropylethynyl-1,2benziodoxol-3(1H)-one (6o) $(62 \mathrm{mg}, 0.20 \mathrm{mmol})$ and cyclohexene sulfide (7a) $(33 \mu \mathrm{L}, 0.30$ mmol). The reaction was stirred at $50{ }^{\circ} \mathrm{C}$ for $4 \mathrm{~h}$. The crude oil was purified by column chromatography (Toluene/Pentane; $3: 7$ to $5: 5)$ to afford 80 (40 $\mathrm{mg}, 0.09 \mathrm{mmol}, 47 \%$ ) as a colorless oil. $\mathrm{R}_{\mathrm{f}} 0.25$ (Toluene/Pentane; 1:3); ${ }^{1} \mathrm{H}$ NMR (400 MHz, Chloroform- $d$ ) $\delta 7.97$ (dd, $J$ $=8.0,1.2 \mathrm{~Hz}, 1 \mathrm{H}, \operatorname{Ar} H), 7.87(\mathrm{dd}, J=7.8,1.7 \mathrm{~Hz}, 1 \mathrm{H}, \operatorname{Ar} H), 7.40(\mathrm{td}, J=7.6,1.2 \mathrm{~Hz}, 1 \mathrm{H}$, $\operatorname{Ar} H), 7.14(\mathrm{td}, J=7.7,1.7 \mathrm{~Hz}, 1 \mathrm{H}, \operatorname{Ar} H), 5.02$ (td, $J=9.9,4.4 \mathrm{~Hz}, 1 \mathrm{H}, \mathrm{OCH}), 2.88$ (ddd, $J=$ 11.3, 9.8, 4.2 Hz, 1H, SCH), $2.38-2.29\left(\mathrm{~m}, 1 \mathrm{H}, \mathrm{CH} \mathrm{H}_{2}\right.$ cyclohexyl), $2.28-2.16\left(\mathrm{~m}, 1 \mathrm{H}, \mathrm{CH}_{2}\right.$ cyclohexyl), $1.86-1.64\left(\mathrm{~m}, 3 \mathrm{H}, \mathrm{CH}_{2}\right.$ cyclohexyl), $1.60-1.22\left(\mathrm{~m}, 4 \mathrm{H}, \mathrm{CH}_{2}\right.$ cyclohexyl + $\mathrm{CH}$ cyclopropyl), $0.82-0.63$ (m, 4H, $\mathrm{CH}_{2}$ cyclopropyl); ${ }^{13} \mathrm{C}$ NMR (100 MHz, Chloroform- $d$ ) $\delta$ 165.8, 141.2, 135.6, 132.6, 131.1, 128.0, 100.9, 94.2, 75.3, 61.2, 50.3, 32.0, 31.9, 25.5, 23.9, 9.2, 1.0; IR ( $\left.v_{\max }, \mathrm{cm}^{-1}\right) 3087(\mathrm{w}), 3010(\mathrm{~m}), 2936(\mathrm{~m}), 2171(\mathrm{w}), 1723(\mathrm{~s}), 1401(\mathrm{~m}), 1281(\mathrm{~m})$, 1250 (s), 1128 (m), 1097 (s), 1016 (s), 803 (s), 739 (s); HRMS (ESI/QTOF) m/z: [M + $\mathrm{Na}]^{+}$Calcd for $\mathrm{C}_{18} \mathrm{H}_{19} \mathrm{INaO}_{2} \mathrm{~S}^{+}$449.0043; Found 449.0051.

\section{2-((5-Chloropent-1-yn-1-yl)thio)cyclohexyl 2-iodobenzoate (8p)}




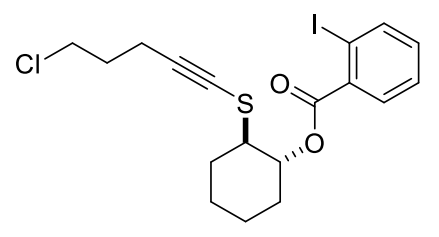

$8 p$

Synthesized following general procedure A starting from (5-Chloropent-1-ynyl)-1,2benziodoxol-3(1H)-one (6p) (70 mg, $0.20 \mathrm{mmol})$ and cyclohexene sulfide (7a) $(33 \mu \mathrm{L}, 0.30$ mmol). The reaction was stirred at $\mathrm{rt}$ for $24 \mathrm{~h}$. The crude oil was purified by column chromatography (Toluene/Pentane; $3: 7$ to $5: 5)$ to afford $\mathbf{8 p}(28 \mathrm{mg}, 0.061 \mathrm{mmol}, 31 \%$ ) as a colorless oil. $\mathrm{R}_{\mathrm{f}} 0.15$ (Toluene/Pentane; 1:3); ${ }^{1} \mathrm{H}$ NMR (400 MHz, Chloroform- $d$ ) $\delta 7.98$ (dd, $J$ $=8.0,1.2 \mathrm{~Hz}, 1 \mathrm{H}, \operatorname{Ar} H), 7.87(\mathrm{dd}, J=7.8,1.7 \mathrm{~Hz}, 1 \mathrm{H}, \operatorname{Ar} H), 7.41(\mathrm{td}, J=7.6,1.2 \mathrm{~Hz}, 1 \mathrm{H}$, $\operatorname{Ar} H), 7.15(\mathrm{td}, J=7.7,1.7 \mathrm{~Hz}, 1 \mathrm{H}, \operatorname{Ar} H), 5.05(\mathrm{td}, J=9.9,4.4 \mathrm{~Hz}, 1 \mathrm{H}, \mathrm{OCH}), 3.64(\mathrm{td}, J=6.5$, $\left.1.1 \mathrm{~Hz}, 2 \mathrm{H}, \mathrm{ClCH}_{2}\right), 2.98-2.83(\mathrm{~m}, 1 \mathrm{H}, \mathrm{SCH}), 2.49\left(\mathrm{t}, J=6.8 \mathrm{~Hz}, 2 \mathrm{H}, \mathrm{C} \equiv \mathrm{CCH}_{2}\right), 2.37-2.29$ (m, 1H, $\mathrm{CH}_{2}$ cyclohexyl), $2.28-2.19(\mathrm{~m}, 1 \mathrm{H}, \mathrm{CH} 2$ cyclohexyl), 1.94 (p, J = 6.6 Hz, 2H, $\mathrm{CH}_{2} \mathrm{CH}_{2} \mathrm{CH}_{2} \mathrm{Cl}$ ), $1.86-1.69$ (m, 3H, $\mathrm{CH}_{2}$ cyclohexyl), 1.57 - 1.31 (m, 3H, $\mathrm{CH}_{2}$ cyclohexyl); ${ }^{13} \mathrm{C}$ NMR (100 MHz, Chloroform- $d$ ) $\delta$ 165.8, 141.3, 135.5, 132.7, 131.1, 128.0, 94.8, 94.2, 75.2, 66.9, 50.2, 43.9, 32.1, 31.8, 31.5, 25.5, 23.9, 17.8; IR ( $\left.v_{\max }, \mathrm{cm}^{-1}\right) 2948(\mathrm{~s}), 2864(\mathrm{~m}), 2090$ (m), 1732 (s), 1577 (w), 1461 (m), 1281 (s), 1245 (s), 1127 (s), 1102 (m), 1016 (m), 856 (m), 676 (m); HRMS (ESI/QTOF) m/z: [M + Na] $]^{+}$Calcd for $\mathrm{C}_{18} \mathrm{H}_{20} \mathrm{ClINaO}_{2} \mathrm{~S}^{+}$484.9809; Found 484.9801 .

\section{2-(((Triisopropylsilyl)ethynyl)thio)cyclohexyl 2-iodo-4,5-dimethoxybenzoate (8q)}

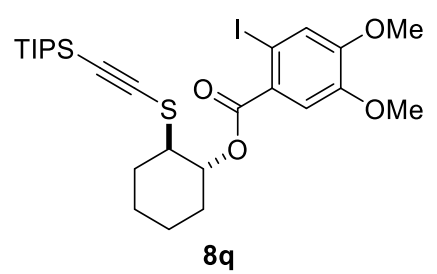

Synthesized following general procedure A starting from 4,5-Dimethoxy-1[(triisopropylsilyl)ethynyl]-1,2-benziodoxol-3(1H)-one $\quad(\mathbf{6 q}) \quad(98 \mathrm{mg}, 0.20 \mathrm{mmol})$ and cyclohexene sulfide (7a) $(33 \mu \mathrm{L}, 0.30 \mathrm{mmol})$. The reaction was stirred at $50{ }^{\circ} \mathrm{C}$ for $5 \mathrm{~h}$. The crude oil was purified by column chromatography (AcOEt/Pentane; 5:95) to afford $\mathbf{8 q}$ (73 mg, $0.12 \mathrm{mmol}, 61 \%$ ) as a yellow oil. $\mathrm{R}_{\mathrm{f}} 0.4$ (AcOEt/Pentane; 1:9); ${ }^{1} \mathrm{H}$ NMR (400 MHz, Chloroform-d) $\delta 7.50(\mathrm{~s}, 1 \mathrm{H}, \operatorname{Ar} H), 7.36(\mathrm{~s}, 1 \mathrm{H}, \operatorname{Ar} H), 4.98(\mathrm{td}, J=10.1,4.5 \mathrm{~Hz}, 1 \mathrm{H}, \mathrm{OCH})$, 
$3.90\left(\mathrm{~s}, 3 \mathrm{H}, \mathrm{OCH}_{3}\right), 3.90\left(\mathrm{~s}, 3 \mathrm{H}, \mathrm{OCH}_{3}\right), 3.05-2.92(\mathrm{~m}, 1 \mathrm{H}, \mathrm{SCH}), 2.44-2.34\left(\mathrm{~m}, 1 \mathrm{H}, \mathrm{CH}_{2}\right.$ cyclohexyl), $2.34-2.25$ (m, 1H, $\mathrm{CH}_{2}$ cyclohexyl), $1.96-1.74\left(\mathrm{~m}, 3 \mathrm{H}, \mathrm{CH}_{2}\right.$ cyclohexyl), 1.61 - 1.30 (m, 3H, CH $H_{2}$ cyclohexyl), 1.06 (s, 21H, TIPS); ${ }^{13} \mathrm{C}$ NMR (100 MHz, Chloroform- $d$ ) $\delta$ 164.7, 151.9, 148.8, 126.8, 123.7, 114.2, 100.1, 92.4, 84.6, 75.0, 56.4, 56.1, 50.5, 32.1, 32.0, 25.6, 24.0, 18.8, 11.5; IR ( $\left.v_{\max }, \mathrm{cm}^{-1}\right) 2943(\mathrm{~m}), 2865(\mathrm{w}), 2085$ (w), $1506(\mathrm{~m}), 1453(\mathrm{w}), 1371$ (m), 1334 (m), 1257 (s), 1206 (s), 1173 (s), 1110 (m), 1020 (m), 874 (m), 856 (m), 731 (m); HRMS (ESI/QTOF) m/z: [M + Na] ${ }^{+}$Calcd for $\mathrm{C}_{26} \mathrm{H}_{39} \mathrm{INaO}_{4} \mathrm{SSi}^{+}$625.1275; Found 625.1279.

\section{2-(((Triisopropylsilyl)ethynyl)thio)cyclohexyl 2-iodo-5-nitrobenzoate (8r)}

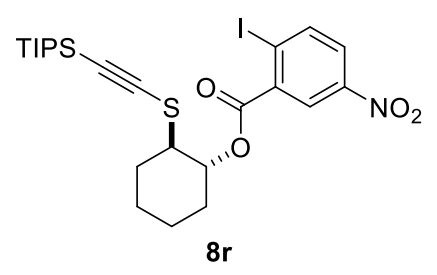

Synthesized following general procedure A starting from 5-Nitro-1[(triisopropylsilyl)ethynyl]-1,2-benziodoxol-3(1H)-one $\quad(6 \mathbf{6 r}) \quad(95 \quad \mathrm{mg}, \quad 0.20 \mathrm{mmol})$ and cyclohexene sulfide (7a) $(33 \mu \mathrm{L}, 0.30 \mathrm{mmol})$. The reaction was stirred at $50{ }^{\circ} \mathrm{C}$ for $3 \mathrm{~h}$. The crude oil was purified by column chromatography (Toluene/Pentane; 4:6) to afford $8 \mathbf{r}$ (70 mg, $0.12 \mathrm{mmol}, 60 \%$ ) as a light yellow solid. $\mathrm{R}_{\mathrm{f}} 0.2$ (Toluene/Pentane; 3:7); Mp: 92-94 ${ }^{\circ} \mathrm{C} ;{ }^{1} \mathrm{H}$ NMR (400 MHz, Chloroform- $d$ ) $\delta 8.62(\mathrm{~d}, J=2.7 \mathrm{~Hz}, 1 \mathrm{H}, \operatorname{Ar} H), 8.20(\mathrm{~d}, J=8.6 \mathrm{~Hz}, 1 \mathrm{H}, \operatorname{Ar} H), 7.97$ (dd, $J=8.6,2.7 \mathrm{~Hz}, 1 \mathrm{H}, \mathrm{Ar} H), 5.14(\mathrm{td}, J=10.2,4.5 \mathrm{~Hz}, 1 \mathrm{H}, \mathrm{OCH}), 2.92$ (ddd, $J=11.5,9.9$, $4.2 \mathrm{~Hz}, 1 \mathrm{H}, \mathrm{SCH}), 2.43-2.24$ (m, 2H, $\mathrm{CH}_{2}$ cyclohexyl), $1.97-1.77$ (m, 3H, $\mathrm{CH}_{2}$ cyclohexyl), $1.65-1.55$ (m, $1 \mathrm{H}, \mathrm{CH}_{2}$ cyclohexyl), $1.51-1.32$ (m, 2H, $\mathrm{CH}_{2}$ cyclohexyl), 1.08 (s, 21H, TIPS); ${ }^{13} \mathrm{C}$ NMR (100 MHz, Chloroform- $d$ ) $\delta$ 163.8, 147.9, 142.8, 137.0, 126.3, 125.6, 102.5, 100.5, 91.9, 75.8, 50.2, 32.0, 31.9, 25.6, 24.0, 18.8, 11.5; IR (v $\left.v_{\max }, \mathrm{cm}^{-1}\right) 2940$ (s), 2862 (s), 2089 (s), 1737 (s), 1527 (s), 1459 (m), 1348 (s), 1263 (s), 1243 (s), 1142 (s), 1116 (m), 1019 (s), 856 (s), 737 (s), 677 (s), 659 (s); HRMS (ESI/QTOF) m/z: $\left[\mathrm{M}+\mathrm{Na}^{+} \mathrm{Calcd}\right.$ for $\mathrm{C}_{24} \mathrm{H}_{34} \mathrm{INNaO}_{4} \mathrm{SSi}^{+}$610.0915; Found 610.0911.

\section{2-(((Triisopropylsilyl)ethynyl)thio)cyclohexyl 3-iodo-2-naphthoate (8s)}




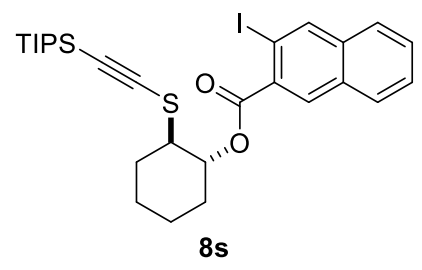

Synthesized following general procedure A starting from 1-((triisopropylsilyl)ethynyl)-1,2naphthiodoxol-3-(1H) (6s) (96 mg, $0.20 \mathrm{mmol})$ and cyclohexene sulfide (7a) $(33 \mu \mathrm{L}, 0.30$ mmol). The reaction was stirred at $50{ }^{\circ} \mathrm{C}$ for $4 \mathrm{~h}$. The crude oil was purified by column chromatography (Toluene/Pentane; 3:7) to afford $\mathbf{8 s}(82 \mathrm{mg}, 0.14 \mathrm{mmol}, 69 \%)$ as a yellow oil. $\mathrm{R}_{\mathrm{f}} 0.5$ (Toluene/Pentane; 3:7); ${ }^{1} \mathrm{H}$ NMR (400 MHz, Chloroform- $d$ ) $\delta 8.49$ (s, 1H, ArH), 8.36 (s, 1H, $\operatorname{ArH}), 7.92-7.86(\mathrm{~m}, 1 \mathrm{H}, \operatorname{ArH}), 7.77-7.71(\mathrm{~m}, 1 \mathrm{H}, \operatorname{Ar} H), 7.56(\mathrm{pd}, J=6.9,1.5 \mathrm{~Hz}, 2 \mathrm{H}$, $\operatorname{Ar} H), 5.11(\mathrm{td}, J=10.1,4.4 \mathrm{~Hz}, 1 \mathrm{H}, \mathrm{OCH}), 3.02(\mathrm{ddd}, J=11.4,9.8,4.2 \mathrm{~Hz}, 1 \mathrm{H}, \mathrm{SCH}), 2.49-$ $2.38\left(\mathrm{~m}, 1 \mathrm{H}, \mathrm{CH}_{2}\right.$ cyclohexyl), $2.38-2.28\left(\mathrm{~m}, 1 \mathrm{H}, \mathrm{CH}_{2}\right.$ cyclohexyl), $1.96-1.78\left(\mathrm{~m}, 3 \mathrm{H}, \mathrm{CH}_{2}\right.$ cyclohexyl), $1.67-1.55$ (m, 1H, $\mathrm{CH}_{2}$ cyclohexyl), $1.52-1.35$ (m, 2H, $\mathrm{CH}_{2}$ cyclohexyl), 1.15 -0.99 (m, 21H, TIPS); ${ }^{13} \mathrm{C}$ NMR (100 MHz, Chloroform- $d$ ) $\delta 165.8,140.7,135.8,131.9,131.8$, 131.6, 129.0, 128.8, 127.4, 126.7, 100.1, 92.5, 88.8, 75.1, 50.5, 32.0, 32.0, 25.6, 24.0, 18.8, 11.5; IR ( $\left.v_{\max }, \mathrm{cm}^{-1}\right) 2940$ (s), 2863 (s), 2089 (m), 1731 (s), 1622 (s), 1611 (s), 1462 (m), 1449 (m), 1276 (s), 1264 (s), 1197 (s), 1103 (s), 1015 (m), 882 (s), 744 (s), 707 (s), 677 (s); HRMS (ESI/QTOF) m/z: [M + Na $]^{+}$Calcd for $\mathrm{C}_{28} \mathrm{H}_{37} \mathrm{INaO}_{2} \mathrm{SSi}^{+}$615.1220; Found 615.1227.

\section{2-(((E)-2-Cyclohexylvinyl)thio)cyclohexyl 2-iodobenzoate (8t)}

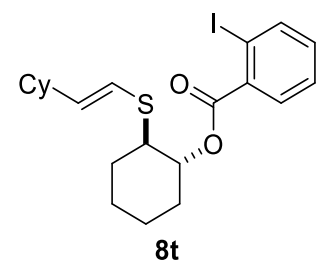

Synthesized following general procedure A starting from (E)-1-(2-cyclohexylvinyl)-1,2benziodoxol-3(1H)-one (6t) (71 mg, $0.20 \mathrm{mmol})$ and cyclohexene sulfide (7a) (33 $\mu \mathrm{L}, 0.30$ mmol). The crude oil was purified by column chromatography (Toluene/Pentane; $1: 1$ ) to afford $\mathbf{8 t}$ (29 mg, $0.062 \mathrm{mmol}, 31 \%$ ) as a colorless oil. $\mathrm{R}_{\mathrm{f}} 0.53$ (Toluene/Pentane; 1:1); ${ }^{1} \mathrm{H}$ NMR (400 MHz, Chloroform- $d$ ) $\delta 7.98(\mathrm{dd}, J=8.0,1.2 \mathrm{~Hz}, 1 \mathrm{H}, \mathrm{Ar} H), 7.84(\mathrm{dd}, J=7.8,1.8 \mathrm{~Hz}, 1 \mathrm{H}, \mathrm{Ar} H)$, $7.39(\mathrm{td}, J=7.6,1.2 \mathrm{~Hz}, 1 \mathrm{H}, \operatorname{Ar} H), 7.14(\mathrm{td}, J=7.6,1.8 \mathrm{~Hz}, 1 \mathrm{H}, \operatorname{Ar} H), 5.95(\mathrm{dd}, J=15.1,1.2$ $\mathrm{Hz}, 1 \mathrm{H}, \mathrm{CH}=\mathrm{CHS}), 5.73(\mathrm{dd}, J=15.2,6.8 \mathrm{~Hz}, 1 \mathrm{H}, \mathrm{CH}=\mathrm{CHS}), 5.01(\mathrm{td}, J=9.3,4.2 \mathrm{~Hz}, 1 \mathrm{H}$, 
OCH), 2.95 (ddd, $J=10.6,9.1,4.1 \mathrm{~Hz}, 1 \mathrm{H}, \mathrm{CHS}), 2.31-2.21$ (m, 1H, $\mathrm{CH}_{2}$ cyclohexyl), 2.20 $-2.11\left(\mathrm{~m}, 1 \mathrm{H}, \mathrm{CH}\right.$ cyclohexyl), $1.97-1.85$ (m, 1H, CH cyclohexyl), $1.84-1.71$ (m, 2H, $\mathrm{CH}_{2}$ cyclohexyl), $1.71-1.50$ (m, 7H, $\mathrm{CH}_{2}$ cyclohexyl), $1.50-1.31$ (m, 2H, $\mathrm{CH}_{2}$ cyclohexyl), 1.30 - 1.06 (m, 3H, CH $\mathrm{H}_{2}$ cyclohexyl), $1.06-0.92$ (m, 2H, $\mathrm{CH}_{2}$ cyclohexyl); ${ }^{13} \mathrm{C}$ NMR (100 MHz, Chloroform- $d$ ) $\delta 165.9,141.3,140.7,135.8,132.5,131.1,128.0,118.7,94.2,76.5,48.7,41.5$, 32.8, 31.6, 31.2, 26.2, 26.1, 25.1, 23.7; IR ( $\left.v_{\max }, \mathrm{cm}^{-1}\right) 2924(\mathrm{~s}), 2853(\mathrm{~m}), 1727(\mathrm{~s}), 1574(\mathrm{w})$, 1453 (m), 1440 (m), 1285 (s), 1246 (s), 1132 (s), 1099 (m), 1011 (m), 946 (m), 741 (s); HRMS (ESI/QTOF) m/z: [M + Na ${ }^{+}$Calcd for $\mathrm{C}_{21} \mathrm{H}_{27} \mathrm{INaO}_{2} \mathrm{~S}^{+}$493.0669; Found 493.0680.

\section{(E)-2-(Styrylthio)cyclohexyl 2-iodobenzoate (8u)}

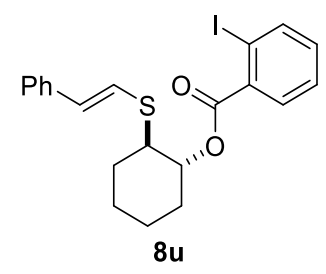

Synthesized following general procedure A starting from (E)-1-styryl-1,2-benziodoxol3(1H)-one (6u) $(70 \mathrm{mg}, 0.20 \mathrm{mmol})$ and cyclohexene sulfide (7a) $(33 \mu \mathrm{L}, 0.30 \mathrm{mmol})$. The reaction was stirred at $70{ }^{\circ} \mathrm{C}$ for $16 \mathrm{~h}$. The crude oil was purified by column chromatography (AcOEt/Pentane; 5:95) to afford $8 \mathbf{u}(33 \mathrm{mg}, 0.071 \mathrm{mmol}, 36 \%)$ as a colorless oil. $\mathrm{R} f 0.34$ (Toluene/Pentane; 1:1); ${ }^{1} \mathrm{H}$ NMR (400 MHz, Chloroform- $d$ ) $\delta 7.90$ (dd, $J=7.9,1.2 \mathrm{~Hz}, 1 \mathrm{H}$, $\operatorname{Ar} H), 7.75(\mathrm{dd}, J=7.8,1.7 \mathrm{~Hz}, 1 \mathrm{H}, \mathrm{Ar} H), 7.26-7.14(\mathrm{~m}, 6 \mathrm{H}, \mathrm{ArH}), 7.04(\mathrm{td}, J=7.6,1.7 \mathrm{~Hz}$, $1 \mathrm{H}, \operatorname{Ar} H), 6.79(\mathrm{~d}, J=15.6 \mathrm{~Hz}, 1 \mathrm{H}, \mathrm{CH}=\mathrm{CHPh}), 6.59(\mathrm{~d}, J=15.6 \mathrm{~Hz}, 1 \mathrm{H}, \mathrm{CH}=\mathrm{CHPh}), 5.10$ $(\mathrm{td}, J=9.4,4.2 \mathrm{~Hz}, 1 \mathrm{H}, \mathrm{OCH}), 3.16$ (ddd, $J=10.9,9.1,4.1 \mathrm{~Hz}, 1 \mathrm{H}, \mathrm{SCH}), 2.35-2.20$ (m, 2H, $\mathrm{CH}_{2}$ cyclohexyl), $1.89-1.74\left(\mathrm{~m}, 2 \mathrm{H}, \mathrm{CH}_{2}\right.$ cyclohexyl), $1.68-1.52\left(\mathrm{~m}, 2 \mathrm{H}, \mathrm{CH}_{2}\right.$ cyclohexyl), $1.51-1.36$ (m, 2H, CH $H_{2}$ cyclohexyl); ${ }^{13} \mathrm{C}$ NMR (100 MHz, Chloroform- $d$ ) $\delta$ 166.0, 141.2, 136.9, 135.5, 132.5, 131.0, 129.6, 128.6, 127.9, 127.1, 125.8, 124.1, 94.1, 77.2, 49.3, 31.8, 31.4, 25.2, 23.8; IR ( $\left.v_{\max }, \mathrm{cm}^{-1}\right) 2932(\mathrm{~m}), 2861(\mathrm{~m}), 2089(\mathrm{~m}), 1726(\mathrm{~s}), 1592(\mathrm{~m}), 1457(\mathrm{~m}), 1281$ (s), 1248 (s), 1104 (m), 1010 (m), 943 (m), 858 (m), 741 (s); HRMS (ESI/QTOF) m/z: [M + $\mathrm{Na}]^{+}$Calcd for $\mathrm{C}_{21} \mathrm{H}_{21} \mathrm{INaO}_{2} \mathrm{~S}^{+}$487.0199; Found 487.0205.

\section{General procedure B: Oxy-alkynylation of thiethanes}




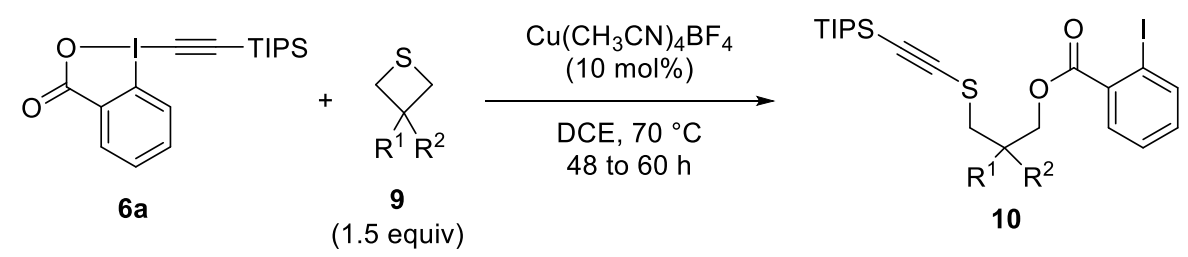

To a microwave vial containing 1-[(triiso-propylsilyl)ethynyl]-1,2-benziodoxol-3(1H)-one (6a) (0.20 mmol, 1 equiv.) was added $\mathrm{Cu}\left(\mathrm{CH}_{3} \mathrm{CN}\right)_{4} \mathrm{BF}_{4}\left(6.3 \mathrm{mg}, 20 \mu \mathrm{mol}, 0.1\right.$ equiv.) under $\mathrm{N}_{2}$ atmosphere. The tube was sealed, DCE (2.5 mL) and a solution of thietane (9) $(0.30 \mathrm{mmol}, 1.5$ equiv.) in DCE $(0.5 \mathrm{~mL})$ were added under $\mathrm{N}_{2}$ atmosphere. The resulting mixture was stirred at $70{ }^{\circ} \mathrm{C}$ for $48 \mathrm{~h}$ (unless otherwise indicated). The reaction was cooled to $\mathrm{rt}$ and concentrated in vacuo. The crude product was purified as described.

\section{3-(((Triisopropylsilyl)ethynyl)thio)propyl 2-iodobenzoate (10a)}

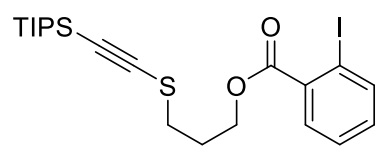

$10 \mathrm{a}$

Synthesized following general procedure B starting from trimethylene sulfide (9a) $(23 \mu \mathrm{L}$, $0.30 \mathrm{mmol}$ ). The crude oil was purified by column chromatography (Toluene/Pentane; $3: 7$ ) to afford 10a (44 mg, $0.088 \mathrm{mmol}, 44 \%$ ) as a colorless oil. $\mathrm{R}_{\mathrm{f}} 0.3$ (Toluene/Pentane; 1:3); ${ }^{1} \mathrm{H}$ NMR (400 MHz, Chloroform- $d$ ) $\delta 7.99$ (dd, $J=7.9,1.2 \mathrm{~Hz}, 1 \mathrm{H}, \mathrm{ArH}), 7.77$ (dd, $J=7.8,1.7 \mathrm{~Hz}, 1 \mathrm{H}$, $\operatorname{Ar} H), 7.40(\mathrm{td}, J=7.6,1.2 \mathrm{~Hz}, 1 \mathrm{H}, \operatorname{Ar} H), 7.16(\mathrm{td}, J=7.7,1.7 \mathrm{~Hz}, 1 \mathrm{H}, \operatorname{Ar} H), 4.49$ (t, $J=6.0$ $\mathrm{Hz}, 2 \mathrm{H}, \mathrm{OCH}_{2}$ ), 2.90 (t, $J=7.0 \mathrm{~Hz}, 2 \mathrm{H}, \mathrm{CH}_{2} \mathrm{~S}$ ), 2.27 (q, $J=6.1 \mathrm{~Hz}, 2 \mathrm{H}, \mathrm{CH}_{2}$ aliphatic), 1.06 (m, 21H, TIPS); ${ }^{13} \mathrm{C}$ NMR (100 MHz, Chloroform- $d$ ) $\delta 166.6,141.4,135.4,132.8,131.1,128.1$, 98.0, 95.0, 94.1, 63.7, 32.4, 28.2, 18.8, 11.5; IR ( $\left.v_{\max }, \mathrm{cm}^{-1}\right) 2953(\mathrm{~m}), 2861(\mathrm{~m}), 2091$ (m), 1728 (s), 1464 (m), 1430 (m), 1285 (s), 1248 (s), 1129 (s), 1009 (m), 882 (m), 857 (m), 741 (s); HRMS (ESI/QTOF) m/z: [M + Na] ${ }^{+}$Calcd for $\mathrm{C}_{21} \mathrm{H}_{31} \mathrm{INaO}_{2} \mathrm{SSi}^{+}$525.0751; Found 525.0758.

\section{2-Phenyl-3-(((triisopropylsilyl)ethynyl)thio)propyl 2-iodobenzoate (10b)}

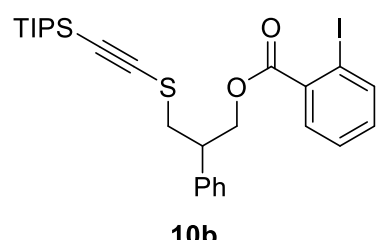


Synthesized following general procedure B starting from 3-phenylthietane (9b) (45 mg, 0.30 mmol). The crude oil was purified by column chromatography (Toluene/Pentane; 1:1) to afford $10 b$ (52 mg, $0.090 \mathrm{mmol}, 45 \%$ ) as an orange oil. $\mathrm{R}_{\mathrm{f}} 0.53$ (Toluene/Pentane; 1:1); ${ }^{1} \mathrm{H}$ NMR (400 MHz, Chloroform- $d$ ) $\delta 7.98(\mathrm{dd}, J=7.9,1.2 \mathrm{~Hz}, 1 \mathrm{H}, \operatorname{Ar} H), 7.65(\mathrm{dd}, J=7.8,1.7 \mathrm{~Hz}, 1 \mathrm{H}, \operatorname{Ar} H$ ), $7.41-7.31$ (m, 3H, ArH), $7.33-7.25$ (m, 3H, ArH), 7.14 (td, J=7.7, 1.7 Hz, 1H, ArH), 4.73 $-4.58\left(\mathrm{~m}, 2 \mathrm{H}, \mathrm{OCH}_{2}\right), 3.60$ (p, $\left.J=6.9 \mathrm{~Hz}, 1 \mathrm{H}, \mathrm{PhCH}\right), 3.27\left(\mathrm{dd}, J=13.0,7.2 \mathrm{~Hz}, 1 \mathrm{H}, \mathrm{SCH}_{2}\right)$, 3.06 (dd, $\left.J=13.0,7.8 \mathrm{~Hz}, 1 \mathrm{H}, \mathrm{SCH}_{2}\right), 1.14-1.00$ (m, 21H, TIPS); ${ }^{13} \mathrm{C}$ NMR (100 MHz, Chloroform- $d$ ) $\delta 166.3,141.5,139.7,135.0,132.8,131.1,128.9,128.1,128.0,127.7,98.2$, 95.0, 94.2, 67.6, 44.1, 38.6, 18.8, 11.5; IR ( $\left.v_{\max }, \mathrm{cm}^{-1}\right) 2947(\mathrm{~m}), 2865(\mathrm{~m}), 2088(\mathrm{~s}), 1728(\mathrm{~s})$, 1589 (w), 1460 (m), 1283 (s), 1248 (s), 1102 (s), 1017 (m), 857 (m), 743 (s); HRMS (ESI/QTOF) m/z: [M + Na $]^{+}$Calcd for $\mathrm{C}_{27} \mathrm{H}_{35} \mathrm{INaO}_{2} \mathrm{SSi}^{+}$601.1064; Found 601.1071.

(2,2-Dimethyl-5-((((triisopropylsilyl)ethynyl)thio)methyl)-1,3-dioxan-5-yl)methyl 2iodobenzoate $(10 \mathrm{c})$

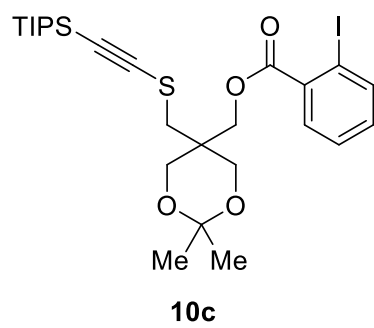

Synthesized following general procedure B starting from 7,7-dimethyl-6,8-dioxa-2thiaspiro[3.5]nonane $(\mathbf{9 c})(52 \mathrm{mg}, 0.30 \mathrm{mmol})$. The reaction was stirred at $70{ }^{\circ} \mathrm{C}$ for $60 \mathrm{~h}$. The crude oil was purified by column chromatography (AcOEt/Pentane; 5:95) to afford 10c $(80 \mathrm{mg}$, $0.13 \mathrm{mmol}, 66 \%$ ) as an orange oil. $\mathrm{R}_{\mathrm{f}} 0.5$ (AcOEt/Pentane; 1:9); ${ }^{1} \mathrm{H}$ NMR (400 MHz, Chloroform- $d$ ) $\delta 7.99(\mathrm{dd}, J=7.9,1.2 \mathrm{~Hz}, 1 \mathrm{H}, \operatorname{Ar} H), 7.76(\mathrm{dd}, J=7.8,1.7 \mathrm{~Hz}, 1 \mathrm{H}, \operatorname{Ar} H), 7.40$ $(\mathrm{td}, J=7.6,1.2 \mathrm{~Hz}, 1 \mathrm{H}, \mathrm{ArH}), 7.16(\mathrm{td}, J=7.7,1.7 \mathrm{~Hz}, 1 \mathrm{H}, \mathrm{ArH}), 4.54\left(\mathrm{~s}, 2 \mathrm{H}, \mathrm{COOCH}_{2}\right), 3.97$ (d, $\left.J=12.1 \mathrm{~Hz}, 2 \mathrm{H}, \mathrm{OCH}_{2}\right), 3.87\left(\mathrm{~d}, J=12.0 \mathrm{~Hz}, 2 \mathrm{H}, \mathrm{OCH}_{2}\right), 3.04\left(\mathrm{~s}, 2 \mathrm{H}, \mathrm{SCH} H_{2}\right), 1.44(\mathrm{~s}, 3 \mathrm{H}$, $\left.\mathrm{CCH}_{3}\right), 1.43$ (s, 3H, CCH ), 1.04 (m, 21H, TIPS); ${ }^{13} \mathrm{C}$ NMR (100 MHz, Chloroform- $d$ ) $\delta$ 166.4, 141.5, 135.3, 132.9, 131.2, 128.1, 98.7, 96.9, 96.3, 94.0, 65.7, 64.1, 39.3, 38.9, 25.3, 22.2, 18.7, 11.4; IR ( $\left.v_{\max }, \mathrm{cm}^{-1}\right) 2995(\mathrm{~m}), 2948(\mathrm{~m}), 2871(\mathrm{~m}), 2089$ (m), 1732 (m), 1462 (w), $1380(\mathrm{~m})$, 1246 (m), 1080 (m), 854 (m), 737 (s); HRMS (ESI/QTOF) m/z: [M + Na $]^{+}$Calcd for $\mathrm{C}_{26} \mathrm{H}_{39} \mathrm{INaO}_{4} \mathrm{SSi}^{+}$625.1275; Found 625.1286. 


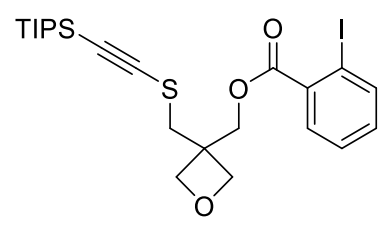

10d

Synthesized following general procedure B starting from 2-oxa-6-thiaspiro[3.3] heptane (9d) (35 mg, $0.30 \mathrm{mmol}$ ). The crude oil was purified by column chromatography (AcOEt/PE; 1:9) to afford 10d (60 mg, $0.11 \mathrm{mmol}, 55 \%)$ as a colorless oil. $\mathrm{R}_{\mathrm{f}} 0.33$ (AcOEt/Pentane; 1:9); ${ }^{1} \mathrm{H}$ NMR (400 MHz, Chloroform-d) $\delta 7.99$ (dd, $J=8.0,1.1 \mathrm{~Hz}, 1 \mathrm{H}, \operatorname{Ar} H), 7.77$ (dd, $J=7.8,1.7$ $\mathrm{Hz}, 1 \mathrm{H}, \mathrm{ArH}), 7.41(\mathrm{td}, J=7.6,1.2 \mathrm{~Hz}, 1 \mathrm{H}, \mathrm{ArH}), 7.17(\mathrm{td}, J=7.7,1.7 \mathrm{~Hz}, 1 \mathrm{H}, \mathrm{ArH}), 4.77$ (s, $\left.2 \mathrm{H}, \mathrm{COOCH}_{2}\right), 4.72\left(\mathrm{~d}, J=6.6 \mathrm{~Hz}, 2 \mathrm{H}, \mathrm{OCH}_{2}\right), 4.61\left(\mathrm{~d}, J=6.6 \mathrm{~Hz}, 2 \mathrm{H}, \mathrm{OCH}_{2}\right), 3.30(\mathrm{~s}, 2 \mathrm{H}$, $\left.\mathrm{SCH}_{2}\right), 1.09-1.00$ (m, 21H, TIPS); ${ }^{13} \mathrm{C}$ NMR (100 MHz, Chloroform- $d$ ) $\delta 166.5,141.5,135.2$, 133.0, 131.3, 128.1, 98.1, 94.8, 94.0, 77.8, 67.0, 44.2, 40.1, 18.7, 11.4; IR $\left(v_{\max }, \mathrm{cm}^{-1}\right) 2952$ (m), 2871 (m), 2089 (w), 1733 (m), 1464 (m), 1422 (m), 1286 (s), 1243 (s), 1129 (m), 984 (m), 855 (m), 738 (s); HRMS (ESI/QTOF) m/z: [M + H] ${ }^{+}$Calcd for $\mathrm{C}_{23} \mathrm{H}_{34} \mathrm{IO}_{3} \mathrm{SSi}^{+}$545.1037; Found 545.1044 .

\section{4-(((Triisopropylsilyl)ethynyl)thio)butyl 2-iodobenzoate (10e)}

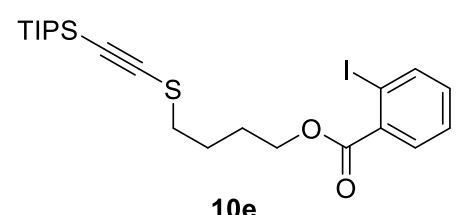

To a microwave vial containing TIPS-EBX (6a) (86.0 mg, $0.20 \mathrm{mmol}, 1.0$ equiv.) was added $\mathrm{Cu}\left(\mathrm{CH}_{3} \mathrm{CN}\right)_{4} \mathrm{BF}_{4}\left(6.3 \mathrm{mg}, 0.020 \mathrm{mmol}, 0.1\right.$ equiv.) under $\mathrm{N}_{2}$ atmosphere. The vial was sealed then DCE (3 mL) and tetrahydrothiophene (9e) $(27 \mu \mathrm{L}, 0.30 \mathrm{mmol}, 1.5$ equiv.) were added under $\mathrm{N}_{2}$ atmosphere. The resulting mixture was stirred at $100{ }^{\circ} \mathrm{C}$ under microwave irradiation for $24 \mathrm{~h}$. The reaction was cooled to rt and concentrated in vacuo. The crude oil was purified by column chromatography $\left(\mathrm{CH}_{2} \mathrm{Cl}_{2} /\right.$ Pentane; 2:8) to afford $10 \mathrm{e}(40 \mathrm{mg}, 0.077 \mathrm{mmol}, 39 \%)$ as a colorless oil. $\mathrm{R}_{\mathrm{f}} 0.28$ (Toluene/Pentane; 1:3); ${ }^{1} \mathrm{H}$ NMR (400 MHz, Chloroform- $d$ ) $\delta 7.99$ (dd, $J=7.9,1.2 \mathrm{~Hz}, 1 \mathrm{H}, \operatorname{Ar} H), 7.78(\mathrm{dd}, J=7.8,1.7 \mathrm{~Hz}, 1 \mathrm{H}, \operatorname{Ar} H), 7.40(\mathrm{td}, J=7.6,1.2 \mathrm{~Hz}, 1 \mathrm{H}$, $\operatorname{ArH}), 7.15(\mathrm{td}, J=7.7,1.7 \mathrm{~Hz}, 1 \mathrm{H}, \operatorname{Ar} H), 4.44-4.31\left(\mathrm{~m}, 2 \mathrm{H}, \mathrm{OCH}_{2}\right), 2.87-2.74(\mathrm{~m}, 2 \mathrm{H}$, 
$\mathrm{SCH}_{2}$ ), $2.04-1.89$ (m, 4H, $\mathrm{CH}_{2}$ aliphatic), 1.05 (s, 21H, TIPS); ${ }^{13} \mathrm{C}$ NMR (100 MHz, Chloroform- $d$ ) $\delta 166.7,141.4,135.4,132.7,131.0,128.0,97.6,95.5,94.2,65.2,35.4,27.3$, 25.9, 18.7, 11.4; IR ( $\left.v_{\max }, \mathrm{cm}^{-1}\right) 2954(\mathrm{~m}), 2869(\mathrm{~m}), 2088(\mathrm{~s}), 1722(\mathrm{~m}), 1464(\mathrm{~m}), 1288(\mathrm{~m})$, 1248 (m), 1128 (m), 996 (m), 856 (s), 741 (s); HRMS (ESI/QTOF) m/z: [M + Ag] ${ }^{+}$Calcd for $\mathrm{C}_{22} \mathrm{H}_{33} \mathrm{AgIO}_{2} \mathrm{SSi}^{+}$623.0061; Found 623.0073. 


\section{Product modifications}

\section{Sonogashira cross-coupling}

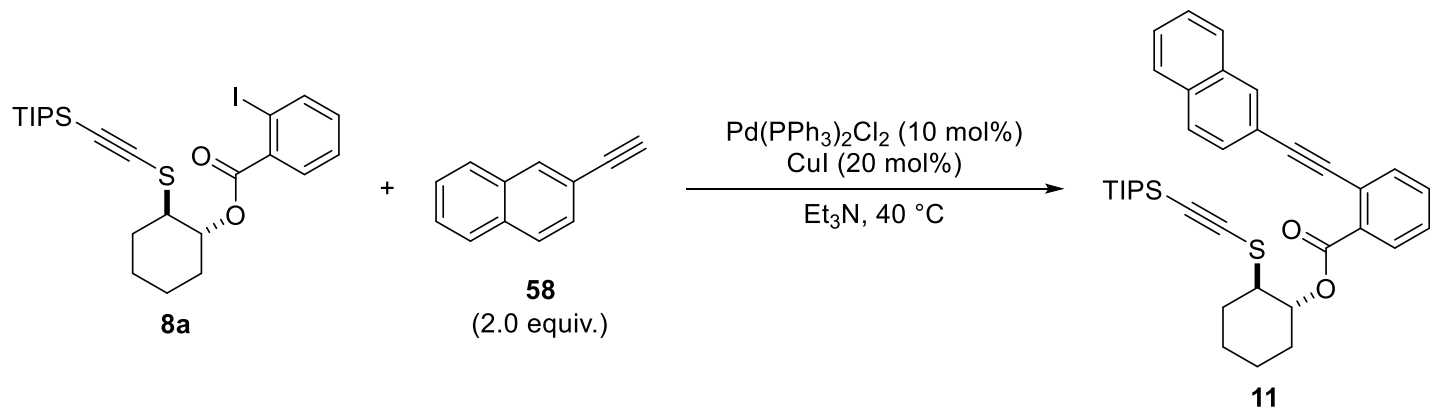

Compound 11 was synthesized following an adapted version of a reported procedure. ${ }^{22}$ To a microwave vial containing 2-(((triisopropylsilyl)ethynyl)thio)cyclohexyl 2-iodobenzoate (8a) (50 mg, $92 \mu \mathrm{mol}, 1.0$ equiv.) and 2-ethynylnaphthalene (58) $(28 \mathrm{mg}, 0.18 \mathrm{mmol}, 2.0$ equiv.) were added $\mathrm{CuI}$ (3.5 mg, $18 \mu \mathrm{mol}, 0.2$ equiv.) and $\mathrm{Pd}\left(\mathrm{PPh}_{3}\right)_{2} \mathrm{Cl}_{2}(6.5 \mathrm{mg}, 9.2 \mu \mathrm{mol}, 0.1$ equiv.) under $\mathrm{N}_{2}$ atmosphere. The vial was sealed and degassed trimethylamine $(3.1 \mathrm{~mL})$ was added under $\mathrm{N}_{2}$ atmosphere. The reaction was heated at $40{ }^{\circ} \mathrm{C}$ for $2.5 \mathrm{~h}$. The reaction was cooled to rt and concentrated in vacuo. The crude solid was dissolved in $\mathrm{CH}_{3} \mathrm{Cl}$ and filtered over $\mathrm{MgSO}_{4}$. The filtrate was successively extracted with $15 \mathrm{~mL}$ of a $1 \mathrm{M}$ aq. sol. of $\mathrm{HCl}$ and $15 \mathrm{~mL}$ of brine. Combined organic layers were dried over $\mathrm{MgSO}_{4}$, filtered and concentrated in vacuo. The crude product was purified by column chromatography $\left(\mathrm{CH}_{2} \mathrm{Cl}_{2} / \mathrm{Pentane} ; 1: 9\right.$ to $\left.2: 8\right)$ to afford 2(((triisopropylsilyl)ethynyl)thio)cyclohexyl 2-(naphthalen-2-ylethynyl)benzoate (11) (36 mg, $63 \mu \mathrm{mol}, 68 \%$ ) as a yellow oil. $\mathrm{R}_{\mathrm{f}} 0.45$ (Toluene/Pentane; 1:3); ${ }^{1} \mathrm{H}$ NMR (400 MHz, Chloroform- $d$ ) $\delta 8.09$ (s, 1H, ArH), 8.04 (dd, J = 7.9, 1.4 Hz, 1H, ArH), $7.86-7.80$ (m, 3H, $\operatorname{Ar} H), 7.69(\mathrm{dd}, J=7.7,1.3 \mathrm{~Hz}, 1 \mathrm{H}, \operatorname{Ar} H), 7.62(\mathrm{dd}, J=8.5,1.6 \mathrm{~Hz}, 1 \mathrm{H}, \operatorname{Ar} H), 7.55-7.47$ (m, $3 \mathrm{H}, \operatorname{Ar} H), 7.40(\mathrm{td}, J=7.7,1.4 \mathrm{~Hz}, 1 \mathrm{H}, \mathrm{ArH}), 5.12(\mathrm{td}, J=9.8,4.4 \mathrm{~Hz}, 1 \mathrm{H}, \mathrm{OCH}), 3.00$ (ddd, $J=11.0,9.6,4.2 \mathrm{~Hz}, 1 \mathrm{H}, \mathrm{SCH}), 2.44-2.34\left(\mathrm{~m}, 1 \mathrm{H}, \mathrm{CH}_{2}\right.$ cyclohexyl), $2.34-2.24\left(\mathrm{~m}, 1 \mathrm{H}, \mathrm{CH}_{2}\right.$ cyclohexyl), $1.91-1.75$ (m, 3H, $\mathrm{CH}_{2}$ cyclohexyl), $1.60-1.30$ (m, 3H, $\mathrm{CH}_{2}$ cyclohexyl), 1.07 (s, 21H, TIPS); ${ }^{13} \mathrm{C}$ NMR (100 MHz, Chloroform- $d$ ) $\delta 165.1,134.3,133.2,133.1,132.2,131.7$, 131.7, 130.7, 128.6, 128.1, 128.1, 128.0, 127.9, 126.9, 126.7, 123.9, 120.9, 99.8, 94.8, 92.9,

\footnotetext{
${ }^{22}$ N. Zhou, L. Wang, D. W. Thompson, Y. Zhao, Org. Lett. 2008, 10, 3001-3004.
} 
88.9, 74.4, 50.5, 31.9, 31.7, 25.4, 23.9, 18.8, 11.5; IR ( $\left.v_{\max }, \mathrm{cm}^{-1}\right) 3058(\mathrm{~m}), 2936(\mathrm{~s}), 2859(\mathrm{~m})$, 2211 (w), 2085 (m), 1718 (s), 1598 (w), 1495 (m), 1451 (m), 1246 (s), 1139 (m), 1067 (s), 857 (m), 814 (m), 750 (s); HRMS (ESI/QTOF) m/z: [M+ H] ${ }^{+}$Calcd for $\mathrm{C}_{36} \mathrm{H}_{43} \mathrm{O}_{2} \mathrm{SSi}^{+}$567.2748; Found 567.2754.

\section{Saponification}

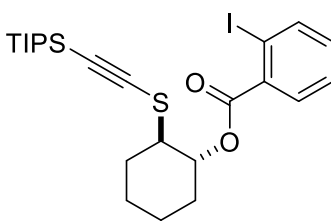

$8 a$

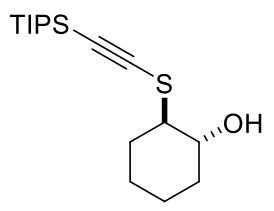

12

Alcohol 12 was synthesized following an adapted version of a reported procedure. ${ }^{8}$ To a microwave vial containing 2-(((Triisopropylsilyl)ethynyl)thio)cyclohexyl 2-iodobenzoate (8a) (50.0 mg, $92 \mu \mathrm{mol}, 1.0$ equiv.) and $\mathrm{K}_{2} \mathrm{CO}_{3}$ (31.8 mg, $0.230 \mathrm{mmol}, 2.5$ equiv.) was added EtOH $(0.92 \mathrm{~mL})$. The vial was sealed and the reaction was stirred at $45^{\circ} \mathrm{C}$ for $30 \mathrm{~h}$. The mixture was cooled to $\mathrm{rt}$ and concentrated in vacuo. The crude product was purified by column chromatography (Toluene/Pentane; 1:1 then AcOEt/Pentane; 5:95) to afford 2(((triisopropylsilyl)ethynyl)thio)cyclohexan-1-ol (12) (24.9 mg, $80 \mu \mathrm{mol}, 86 \%)$ as a colourless oil. $\mathrm{R}_{\mathrm{f}} 0.53$ (AcOEt/Pentane; 1:9); ${ }^{1} \mathrm{H}$ NMR (400 MHz, Chloroform- $d$ ) $\delta 3.63$ (td, $J=10.0,4.4$ $\mathrm{Hz}, 1 \mathrm{H}, \mathrm{OCH}), 2.70$ (s, 1H, OH), 2.49 (ddd, $J=11.9,9.5,4.1 \mathrm{~Hz}, 1 \mathrm{H}, \mathrm{SCH}), 2.20-2.05$ (m, $2 \mathrm{H}, \mathrm{CH}_{2}$ cyclohexyl), $1.83-1.72\left(\mathrm{~m}, 3 \mathrm{H}, \mathrm{CH}_{2}\right.$ cyclohexyl), $1.43-1.20\left(\mathrm{~m}, 3 \mathrm{H}, \mathrm{CH}_{2}\right.$ cyclohexyl), 1.07 (m, 21H, TIPS); ${ }^{13} \mathrm{C}$ NMR (100 MHz, Chloroform- $d$ ) $\delta$ 99.5, 91.8, 71.6, 55.3, 33.9, 31.7, 26.3, 24.5, 18.8, 11.5; IR ( $\left.v_{\max }, \mathrm{cm}^{-1}\right) 3411(\mathrm{w}), 2935$ (s), 2864 (m), 2087 (m), 1461 (m), 1224 (m), 1195 (m), 1068 (s), 857 (s); HRMS (ESI/QTOF) m/z: [M + H] Calcd for $\mathrm{C}_{17} \mathrm{H}_{33} \mathrm{OSSi}^{+}$313.2016; Found 313.2013.

\section{TIPS deprotection}<smiles>O=C(O[C@H]1CCCC[C@@H]1SC#CSP)c1ccccc1I</smiles>

$8 a$

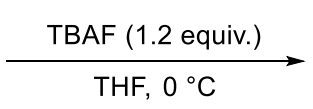<smiles>C#CSC1CCCC[C@@H]1OC(=O)c1ccccc1I</smiles>

13 
Terminal alkyne $\mathbf{1 3}$ was synthesized following an adapted version of a reported procedure. ${ }^{8} \mathrm{~A}$ microwave vial containing a solution of 2-(((triisopropylsilyl)ethynyl)thio)cyclohexyl 2iodobenzoate (8a) $\left(0.4 \mathrm{~g}, 0.74 \mathrm{mmol}, 1.0\right.$ equiv.) in THF $(9.2 \mathrm{~mL})$ was cooled to $0{ }^{\circ} \mathrm{C}$. Then, a $1 \mathrm{M}$ solution of TBAF in THF was added $(0.89 \mathrm{~mL}, 0.89 \mathrm{mmol}, 1.2$ equiv. $)$ and the mixture was stirred at $0{ }^{\circ} \mathrm{C}$ for $1 \mathrm{~h}$. The reaction was allowed to warm to $\mathrm{rt}$ and quenched by the addition of $20 \mathrm{~mL}$ of a sat. sol. of $\mathrm{NH}_{4} \mathrm{Cl}$. The mixture was extracted with 3 x $20 \mathrm{~mL}$ of $\mathrm{Et}_{2} \mathrm{O}$, combined organic layers were dried over $\mathrm{MgSO}_{4}$, filtered and concentrated in vacuo. The crude compound was purified by column chromatography (AcOEt/Pentane; 3:97) to afford 2(ethynylthio)cyclohexyl 2-iodobenzoate $(\mathbf{1 3})(0.27 \mathrm{~g}, 0.71 \mathrm{mmol}, 97 \%)$ as a brown oil.. $\mathrm{R}_{\mathrm{f}} 0.15$ (Toluene/Pentane; 1:3); ${ }^{1} \mathrm{H}$ NMR (400 MHz, Chloroform- $d$ ) $\delta 7.98(\mathrm{dd}, J=8.0,1.2 \mathrm{~Hz}, 1 \mathrm{H}$, $\operatorname{Ar} H), 7.86(\mathrm{dd}, J=7.8,1.7 \mathrm{~Hz}, 1 \mathrm{H}, \operatorname{Ar} H), 7.40(\mathrm{td}, J=7.6,1.2 \mathrm{~Hz}, 1 \mathrm{H}, \operatorname{Ar} H), 7.15(\mathrm{td}, J=7.7$, $1.7 \mathrm{~Hz}, 1 \mathrm{H}, \mathrm{Ar} H), 5.07$ (td, $J=10.0,4.4 \mathrm{~Hz}, 1 \mathrm{H}, \mathrm{OCH}), 2.99$ (ddd, $J=11.1,9.8,4.2 \mathrm{~Hz}, 1 \mathrm{H}$, $\mathrm{SCH}), 2.85(\mathrm{~s}, 1 \mathrm{H}, \mathrm{C} \equiv \mathrm{CH}), 2.41-2.23\left(\mathrm{~m}, 2 \mathrm{H}, \mathrm{CH}_{2}\right.$ cyclohexyl), $1.89-1.77\left(\mathrm{~m}, 3 \mathrm{H}, \mathrm{CH}_{2}\right.$ cyclohexyl), $1.62-1.33$ (m, 3H, CH $H_{2}$ cyclohexyl); ${ }^{13} \mathrm{C}$ NMR (100 MHz, Chloroform- $d$ ) $\delta 165.8$, 141.3, 135.4, 132.7, 131.1, 128.0, 94.2, 84.5, 75.0, 71.7, 50.2, 31.9, 31.9, 25.5, 23.9; IR ( $v_{\max }$, $\left.\mathrm{cm}^{-1}\right) 3285$ (m), 2938 (m), 2861 (w), 1726 (s), 1284 (s), 1252 (s), 1132 (m), 1103 (s), 1039 (m), 1015 (m), 743 (s); HRMS (ESI/QTOF) m/z: [M + Na ${ }^{+}$Calcd for $\mathrm{C}_{15} \mathrm{H}_{15} \mathrm{INaO}_{2} \mathrm{~S}^{+} 408.9730$; Found 408.9731 .

\section{CuAAC}
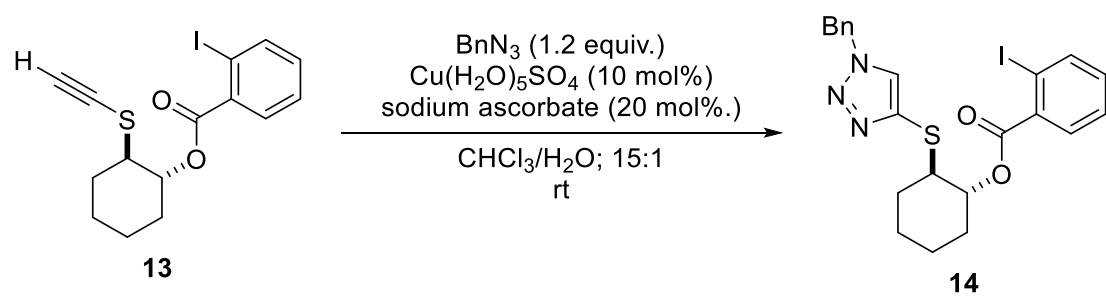

Triazole 14 was synthesized following an adapted version of a reported procedure. ${ }^{12} \mathrm{~A}$ microwave vial containing 2-(ethynylthio)cyclohexyl 2-iodobenzoate (13) (77 mg, $0.20 \mathrm{mmol}$, 1.0 equiv. $)$ in a mixture of $\mathrm{CHCl}_{3}(3.1 \mathrm{~mL})$ and water $(0.2 \mathrm{~mL})$ were added $\mathrm{Cu}\left(\mathrm{H}_{2} \mathrm{O}\right)_{5} \mathrm{SO}_{4}(5.0$ $\mathrm{mg}, 0.020 \mathrm{mmol}, 0.1$ equiv.), sodium ascorbate (7.9 mg, $0.040 \mathrm{mmol}, 0.2$ equiv.) and $\mathrm{BnN}_{3}(32$ $\mu \mathrm{L}, 0.24 \mathrm{mmol}, 1.2$ equiv.). The vial was sealed and the reaction was stirred at $\mathrm{rt}$ for $24 \mathrm{~h}$. The mixture was diluted with $2 \mathrm{~mL}$ of water then extracted with $3 \times 2 \mathrm{~mL}$ of $\mathrm{CH}_{2} \mathrm{Cl}_{2}$. Combined organic layers were dried over $\mathrm{MgSO}_{4}$, filtered and concentrated in vacuo. The crude product 
was purified by column chromatography (AcOEt/Pentane; 0:1 to 3:7) to afford 2-((1-benzyl$1 H$-1,2,3-triazol-4-yl)thio)cyclohexyl 2-iodobenzoate (14) (84 mg, $0.16 \mathrm{mmol}, 80 \%)$ as a colorless oil. $\mathrm{R}_{\mathrm{f}} 0.22$ (AcOEt/Pentane; 1:9); ${ }^{1} \mathrm{H}$ NMR (400 MHz, Chloroform- $d$ ) $\delta 7.98$ (dd, $J$ $=8.0,1.2 \mathrm{~Hz}, 1 \mathrm{H}, \operatorname{Ar} H), 7.78(\mathrm{dd}, J=7.8,1.7 \mathrm{~Hz}, 1 \mathrm{H}, \mathrm{Ar} H), 7.56(\mathrm{~s}, 1 \mathrm{H}, \mathrm{C}=\mathrm{C} H), 7.42-7.30$ (m, 4H, ArH), $7.25-7.19$ (m, 2H, ArH), 7.14 (td, $J=7.7,1.7 \mathrm{~Hz}, 1 \mathrm{H}, \operatorname{Ar} H), 5.44$ (d, $J=14.8$ $\left.\mathrm{Hz}, 1 \mathrm{H}, \mathrm{PhCH}_{2}\right), 5.39$ (d, $\left.J=14.8 \mathrm{~Hz}, 1 \mathrm{H}, \mathrm{PhCH}_{2}\right), 4.89$ (td, $\left.J=9.9,4.4 \mathrm{~Hz}, 1 \mathrm{H}, \mathrm{OCH}\right), 3.18$ (ddd, $J=11.2,9.6,4.1 \mathrm{~Hz}, 1 \mathrm{H}, \mathrm{SCH}), 2.31-2.12$ (m, 2H, $\mathrm{CH}_{2}$ cyclohexyl), $1.84-1.69$ (m, $2 \mathrm{H}, \mathrm{CH}_{2}$ cyclohexyl), $1.63-1.41\left(\mathrm{~m}, 2 \mathrm{H}, \mathrm{CH}_{2}\right.$ cyclohexyl), $1.40-1.27\left(\mathrm{~m}, 2 \mathrm{H}, \mathrm{CH}_{2}\right.$ cyclohexyl); ${ }^{13} \mathrm{C}$ NMR (100 MHz, Chloroform- $d$ ) $\delta 165.8,141.4,137.4,135.2,134.3,132.8$, 131.2, 129.3, 128.9, 128.2, 128.1, 128.0, 94.3, 75.7, 54.4, 50.5, 32.3, 31.7, 25.4, 23.9; IR ( $v_{\max }$, $\left.\mathrm{cm}^{-1}\right) 2934$ (w), 2359 (w), 2093 (m), 1720 (m), 1448 (m), 1429 (m), 1290 (s), 1252 (s), 1193 (m), 1139 (s), 1099 (s), 1042 (s), 1014 (s), 742 (s), 722 (s); HRMS (ESI/QTOF) m/z: [M + $\mathrm{H}]^{+}$Calcd for $\mathrm{C}_{22} \mathrm{H}_{23} \mathrm{IN}_{3} \mathrm{O}_{2} \mathrm{~S}^{+}$520.0550; Found 520.0558.

\section{Large scale experiment}

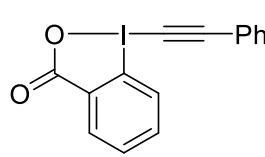

$6 k$

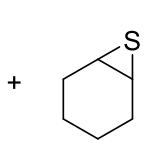

$7 \mathrm{a}$ (1.5 equiv)

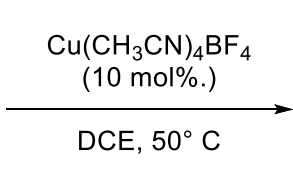

DCE, $50^{\circ} \mathrm{C}$

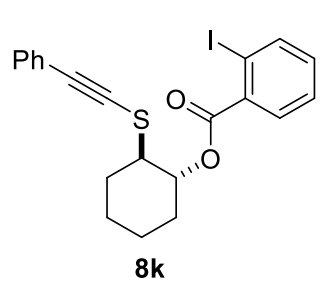

To a round bottom flask containing 1-[phenylethynyl]-1,2-benziodoxol-3(1H)-one (6k) (696 mg, 2.00 mmol, 1.0 equiv.) was added $\mathrm{Cu}\left(\mathrm{CH}_{3} \mathrm{CN}\right)_{4} \mathrm{BF}_{4}(62.9 \mathrm{mg}, 0.200 \mathrm{mmol}, 0.1$ equiv.) under $\mathrm{N}_{2}$ atmosphere. Then, DCE (30 mL) and cyclohexene sulfide (7a) $(0.33 \mathrm{~mL}, 3.0 \mathrm{mmol}$, 1.5 equiv.) were added under $\mathrm{N}_{2}$ atmosphere. The resulting mixture was stirred at $50{ }^{\circ} \mathrm{C}$ for 3 h. The reaction was cooled to $\mathrm{rt}$ and concentrated in vacuo. The crude oil was purified by column chromatography (Toluene/Pentane; 1:1) to afford 8k (503 mg, $1.09 \mathrm{mmol}, 54 \%$ ) as an orange oil.

\section{Thioalkyne hydratation}




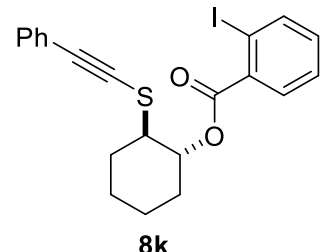

8k

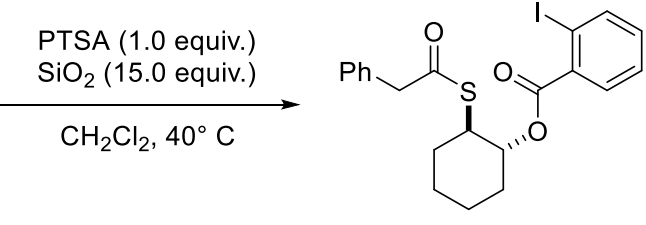

15

Thioester 15 was synthesized following an adapted version of a reported procedure. ${ }^{23}$ To a microwave vial containing a solution of 2-((phenylethynyl)thio)cyclohexyl 2-iodobenzoate (8k) (0.14 g, $0.30 \mathrm{mmol}, 1.0$ equiv.) in $\mathrm{CH}_{2} \mathrm{Cl}_{2}(1.5 \mathrm{~mL})$ were added PTSA (57 mg, $0.30 \mathrm{mmol}$, 1.0 equiv.) and $\mathrm{SiO}_{2}(0.27 \mathrm{~g}, 4.5 \mathrm{mmol}, 15.0$ equiv.). The vial was sealed and the reaction was stirred at $40{ }^{\circ} \mathrm{C}$ for $24 \mathrm{~h}$. The reaction was cooled to $\mathrm{rt}$ and the silica was filtrated and rinsed with AcOEt. The resulting solution was concentrated in vacuo. The crude product was purified by column chromatography (AcOEt/Pentane; 5:95) to afford 2-((2phenylacetyl)thio)cyclohexyl 2-iodobenzoate (15) $(0.12 \mathrm{~g}, 0.25 \mathrm{mmol}, 83 \%)$ as an orange oil. $\mathrm{R}_{\mathrm{f}} 0.45$ (AcOEt/Pentane; 1:9); ${ }^{1} \mathrm{H}$ NMR (400 MHz, Chloroform- $d$ ) $\delta 7.98$ (d, $J=7.9 \mathrm{~Hz}, 1 \mathrm{H}$, $\operatorname{Ar} H$ ), $7.63(\mathrm{dd}, J=7.8,1.7 \mathrm{~Hz}, 1 \mathrm{H}, \operatorname{Ar} H), 7.31-7.15(\mathrm{~m}, 6 \mathrm{H}, \operatorname{Ar} H), 7.12$ (t, $J=7.7,1.7 \mathrm{~Hz}$, 1H, $\mathrm{ArH}), 4.96(\mathrm{td}, J=9.9,4.2 \mathrm{~Hz}, 1 \mathrm{H}, \mathrm{OCH}), 3.82-3.69\left(\mathrm{~m}, 3 \mathrm{H}, \mathrm{SCH}+\mathrm{PhCH}_{2}\right), 2.23-2.07$ (m, 2H, $\mathrm{CH}_{2}$ cyclohexyl), $1.87-1.77\left(\mathrm{~m}, 1 \mathrm{H}, \mathrm{CH}_{2}\right.$ cyclohexyl), $1.76-1.67\left(\mathrm{~m}, 1 \mathrm{H}, \mathrm{CH}_{2}\right.$ cyclohexyl), $1.66-1.50\left(\mathrm{~m}, 2 \mathrm{H}, \mathrm{CH}_{2}\right.$ cyclohexyl), $1.49-1.36\left(\mathrm{~m}, 2 \mathrm{H}, \mathrm{CH}_{2}\right.$ cyclohexyl); ${ }^{13} \mathrm{C}$ NMR (100 MHz, Chloroform-d) $\delta$ 196.4, 165.5, 141.5, 134.5, 133.5, 132.8, 131.2, 129.6, 128.7, 128.0, 127.5, 94.5, 74.9, 50.8, 46.1, 32.3, 31.9, 25.4, 23.8; IR ( $\left.v_{\max }, \mathrm{cm}^{-1}\right) 3060(\mathrm{w}), 2933(\mathrm{~m})$, 1721 (s), 1688 (s), 1439 (m), 1282 (s), 1250 (s), 1137 (m), 1101 (m), 1011 (s), 712 (s); HRMS (ESI/QTOF) m/z: $[\mathrm{M}+\mathrm{Na}]^{+}$Calcd for $\mathrm{C}_{21} \mathrm{H}_{21} \mathrm{INaO}_{3} \mathrm{~S}^{+}$503.0148; Found 503.0161.

\footnotetext{
${ }^{23}$ A. L. Braga, T. L. C. Martins, C. C. Silveira, O. E. D. Rodrigues, Tetrahedron 2001, 57, 3297-3300.
} 


\section{Control experiments}

\section{Ring opening of thiirane without copper in the presence of a carboxylic acid}

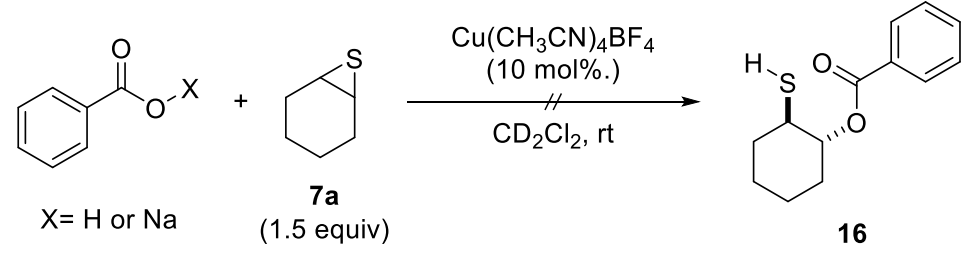

To a microwave vial containing sodium benzoate ( $14.0 \mathrm{mg}, 0.100 \mathrm{mmol}, 1.0$ equiv.) or benzoic acid (12.2 mg, $0.100 \mathrm{mmol}, 1.0$ equiv.) was added $\mathrm{Cu}\left(\mathrm{CH}_{3} \mathrm{CN}\right)_{4} \mathrm{BF}_{4}(3.2 \mathrm{mg}, 0.010 \mathrm{mmol}, 0.1$ equiv.) under $\mathrm{N}_{2}$ atmosphere. The vial was sealed then $\mathrm{CD}_{2} \mathrm{Cl}_{2}(1.5 \mathrm{~mL})$ and cyclohexene sulfide (7a) (16 $\mu \mathrm{L}, 0.15 \mathrm{mmol}, 1.5$ equiv.) were added under $\mathrm{N}_{2}$ atmosphere. The resulting mixture was stirred at $\mathrm{rt}$ for $72 \mathrm{~h}$. No trace of the expected product was observed, only unreacted starting material.

Oxy-alkynylation of cyclohexene oxide (17)

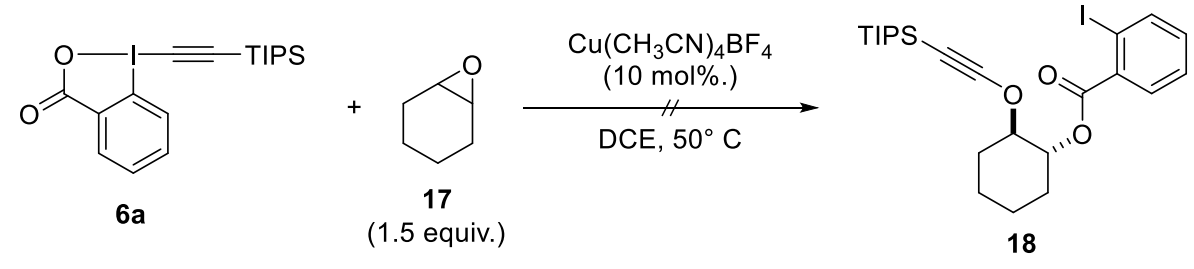

To a microwave vial containing TIPS-EBX (6a) (43.0 mg, $0.100 \mathrm{mmol}, 1.0$ equiv.) was added $\mathrm{Cu}\left(\mathrm{CH}_{3} \mathrm{CN}\right)_{4} \mathrm{BF}_{4}\left(3.2 \mathrm{mg}, 0.010 \mathrm{mmol}, 0.1\right.$ equiv.) under $\mathrm{N}_{2}$ atmosphere. The vial was sealed then DCE (1.5 mL) and cyclohexene oxide (17) $(15 \mu \mathrm{L}, 0.15 \mathrm{mmol}, 1.5$ equiv.) were added under $\mathrm{N}_{2}$ atmosphere. The reaction was stirred at $50{ }^{\circ} \mathrm{C}$ for $48 \mathrm{~h}$. No trace of the expected product was observed, only unreacted starting material.

\section{Oxy-alkynylation with iodonium salt}

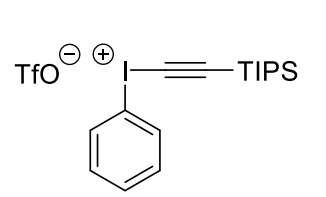

6v

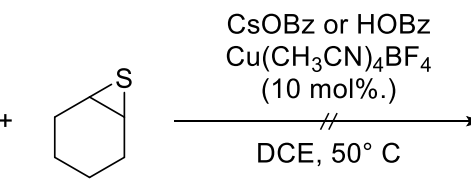

$7 a$

(1.5 equiv)<smiles>CC(C)[Sn]C#CSC1CCCC[C@@H]1OC(=O)c1ccccc1</smiles>

19 
To a microwave vial containing phenyl((triisopropylsilyl)ethynyl)iodonium trifluoromethanesulfonate (6v) $(53.0 \mathrm{mg}, 0.100 \mathrm{mmol}, 1.0$ equiv.) and cesium benzoate (25.0 $\mathrm{mg}, 0.100 \mathrm{mmol}, 1.0$ equiv.) or benzoic acid (12.0 mg, $0.100 \mathrm{mmol}, 1.0$ equiv.) was added $\mathrm{Cu}\left(\mathrm{CH}_{3} \mathrm{CN}\right)_{4} \mathrm{BF}_{4}\left(3.2 \mathrm{mg}, 0.010 \mathrm{mmol}, 0.1\right.$ equiv.) under $\mathrm{N}_{2}$ atmosphere. The vial was sealed then DCE (1.5 mL) and cyclohexene sulfide (7a) $(16 \mu \mathrm{L}, 0.15 \mathrm{mmol}, 1.5$ equiv.) were added under $\mathrm{N}_{2}$ atmosphere. The reaction was stirred at $50{ }^{\circ} \mathrm{C}$ for $6 \mathrm{~h}$. Only traces of the desired product 19 could be detected by NMR.

\section{Oxy-Alkynylation in the presence of TEMPO}

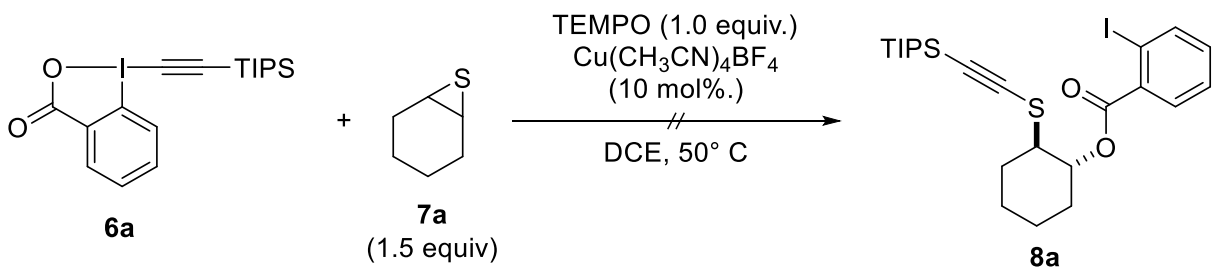

To a microwave vial containing TIPS-EBX (6a) (43.0 mg, $0.100 \mathrm{mmol}, 1.0$ equiv.) was added $\mathrm{Cu}\left(\mathrm{CH}_{3} \mathrm{CN}\right)_{4} \mathrm{BF}_{4}\left(3.2 \mathrm{mg}, 0.010 \mathrm{mmol}, 0.1\right.$ equiv.) under $\mathrm{N}_{2}$ atmosphere. The vial was sealed then DCE $(1.0 \mathrm{~mL})$, cyclohexene sulfide (7a) $(16 \mu \mathrm{L}, 0.15 \mathrm{mmol}, 1.5$ equiv.) and a solution of TEMPO (15.9 mg, 0.100 mmol, 1.0 equiv.) in DCE ( $0.5 \mathrm{~mL})$ were added under $\mathrm{N}_{2}$ atmosphere. The reaction was stirred at $50{ }^{\circ} \mathrm{C}$ for $4 \mathrm{~h}$. The reaction was cooled to $\mathrm{rt}$ and concentrated in vacuo. The crude oil was purified by preparative TLC (Toluene/Pentane; 1:3) to afford $\mathbf{8 a}$ as a colorless oil (15 mg, $0.027 \mathrm{mmol}, 27 \%)$.

\section{Oxy-alkynylation of benzyl sulfide (20)}

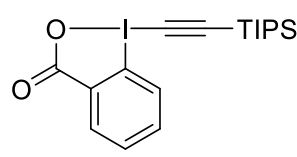

$6 a$

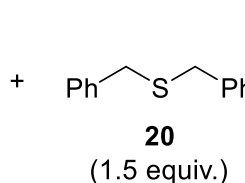

(1.5 equiv.)

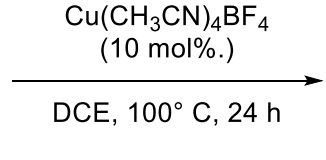

DCE, $100^{\circ} \mathrm{C}, 24 \mathrm{~h}$

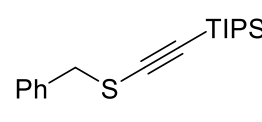

21a

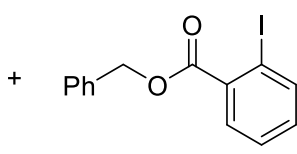

21b

To a microwave vial containing TIPS-EBX (6a) $(86.0 \mathrm{mg}, 0.200 \mathrm{mmol}, 1.0$ equiv.) was added $\mathrm{Cu}\left(\mathrm{CH}_{3} \mathrm{CN}\right)_{4} \mathrm{BF}_{4}\left(6.3 \mathrm{mg}, 0.020 \mathrm{mmol}, 0.1\right.$ equiv.) under $\mathrm{N}_{2}$ atmosphere. The vial was sealed then DCE (2.5 mL) and a solution of benzyl sulfide (20) $(64.3 \mathrm{mg}, 0.300 \mathrm{mmol}, 1.5$ equiv.) in DCE $(0.5 \mathrm{~mL})$ were added under $\mathrm{N}_{2}$ atmosphere. The reaction was stirred at $100{ }^{\circ} \mathrm{C}$ under microwave irradiation for $24 \mathrm{~h}$. The reaction was cooled to $\mathrm{rt}$ and concentrated in vacuo. The 
crude oil was purified by column chromatography (Toluene/Pentane; 0:1 to 1:1) to afford ((benzylthio)ethynyl)triisopropylsilane (21a) (21 mg, $0.068 \mathrm{mmol}, 34 \%)$ and benzyl 2iodobenzoate (21b) (26 mg, $0.078 \mathrm{mmol}, 39 \%)$ as colourless oils. 21a: ${ }^{1} \mathrm{H}$ NMR (400 MHz, Chloroform- $d$ ) $\delta 7.38-7.27$ (m, 5H, $\mathrm{ArH}$ ), 3.94 (s, 2H, $\left.\mathrm{PhCH}_{2}\right), 1.07-0.99$ (m, 21H, TIPS). Spectroscopic data was consistent with the values reported in literature. ${ }^{12} \mathbf{2 1 b}:{ }^{1} \mathrm{H}$ NMR (400 MHz, Chloroform- $d$ ) $\delta 7.99(\mathrm{dd}, J=8.0,1.2 \mathrm{~Hz}, 1 \mathrm{H}, \operatorname{Ar} H), 7.82(\mathrm{dd}, J=7.8,1.7 \mathrm{~Hz}, 1 \mathrm{H}, \operatorname{Ar} H$ ), $7.51-7.44(\mathrm{~m}, 2 \mathrm{H}, \mathrm{ArH}), 7.44-7.32(\mathrm{~m}, 4 \mathrm{H}, \operatorname{Ar} H), 7.15(\mathrm{td}, J=7.7,1.7 \mathrm{~Hz}, 1 \mathrm{H}, \operatorname{Ar} H), 5.38$ ( $\left.\mathrm{s}, 2 \mathrm{H}, \mathrm{PhCH}_{2}\right)$. Spectroscopic data was consistent with the values reported in literature. ${ }^{24}$

\section{Competitive experiment}<smiles>O=C1OI(C#Cc2ccccc2)c2ccccc21</smiles>

$6 \mathrm{k}$

(0.5 equiv.)<smiles>COc1cc2c(cc1OC)I(C#C[In])OC2=O</smiles>
(0.5 equiv.)

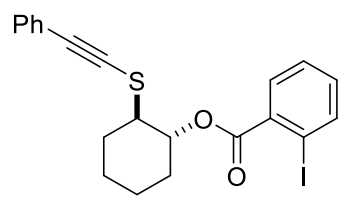

$8 \mathbf{k}$

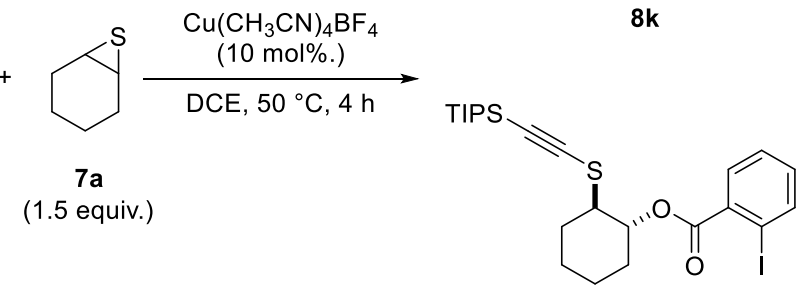

8a<smiles>COc1cc(I)c(C(=O)O[C@H]2CCCCC2SC#CSC(C)C)cc1OC</smiles>

$8 q$<smiles>COc1cc(I)c(C(=O)O[C@H]2CCCCC2SC#Cc2ccccc2)cc1OC</smiles>

$8 v$

To a microwave vial containing 1-[phenylethynyl]-1,2-benziodoxol-3(1H)-one (6k) $(34.8 \mathrm{mg}$, 0.100 mmol, 0.5 equiv.) and 4,5-dimethoxy-1-[(triisopropylsilyl)ethynyl]-1,2-benziodoxol3(1H)-one (6q) (48.8 mg, 0.100 mmol, 0.5 equiv.) was added $\mathrm{Cu}\left(\mathrm{CH}_{3} \mathrm{CN}\right)_{4} \mathrm{BF}_{4}(6.3 \mathrm{mg}, 0.020$ mmol, 0.1 equiv.) under $\mathrm{N}_{2}$ atmosphere. The vial was sealed then DCE ( $\left.3 \mathrm{~mL}\right)$ and cyclohexene sulfide (7a) $\left(33 \mu \mathrm{L}, 0.30 \mathrm{mmol}, 1.5\right.$ equiv.) were added under $\mathrm{N}_{2}$ atmosphere. The reaction was stirred at $50{ }^{\circ} \mathrm{C}$ for $4.5 \mathrm{~h}$. The reaction was cooled to $\mathrm{rt}$ and concentrated in vacuo. The crude oil was purified by column chromatography (Toluene/Pentane; 0:1 to 1:1 then AcOEt/Pentane; 5:95 to 10:90) to afford $\mathbf{8 a}$ (14 mg, $0.025 \mathrm{mmol}, 13 \%), \mathbf{8 k}(18 \mathrm{mg}, 0.039 \mathrm{mmol}, 19 \%), \mathbf{8 q}$ (28 $\mathrm{mg}, 0.046 \mathrm{mmol}, 23 \%$ ) and $\mathbf{8 v}$ (13 mg, $0.024 \mathrm{mmol}, 12 \%) . \mathbf{8 v}: \mathrm{R}_{\mathrm{f}} 0.2$ (AcOEt/Pentane; 1:9); ${ }^{1} \mathrm{H}$ NMR (400 MHz, Chloroform-d) $\delta 7.52(\mathrm{~s}, 1 \mathrm{H}, \mathrm{ArH}), 7.40-7.36(\mathrm{~m}, 2 \mathrm{H}, \mathrm{ArH}), 7.35(\mathrm{~s}, 1 \mathrm{H}$,

\footnotetext{
${ }^{24}$ W. G. Whitehurst, J. H. Blackwell, G. N. Hermann, M. J. Gaunt, Angew. Chem. Int. Ed. 2019, 58, 9054-9059.
} 
$\operatorname{Ar} H), 7.27(\mathrm{~d}, J=2.7 \mathrm{~Hz}, 3 \mathrm{H}, \mathrm{Ar} H), 5.09(\mathrm{td}, J=10.1,4.4 \mathrm{~Hz}, 1 \mathrm{H}, \mathrm{OCH}), 3.90\left(\mathrm{~s}, 3 \mathrm{H}, \mathrm{OCH}_{3}\right)$, $3.87\left(\mathrm{~s}, 3 \mathrm{H}, \mathrm{OCH}_{3}\right), 3.13(\mathrm{ddd}, J=11.3,9.9,4.2 \mathrm{~Hz}, 1 \mathrm{H}, \mathrm{SCH}), 2.42-2.28\left(\mathrm{~m}, 2 \mathrm{H}, \mathrm{CH}_{2}\right.$ cyclohexyl), $1.91-1.77$ (m, 3H, $\mathrm{CH}_{2}$ cyclohexyl), $1.68-1.31\left(\mathrm{~m}, 3 \mathrm{H}, \mathrm{CH}_{2}\right.$ cyclohexyl); ${ }^{13} \mathrm{C}$ NMR (100 MHz, Chloroform- $d$ ) $\delta 164.9,152.0,148.8,131.7,128.3,128.2,126.7,123.7,123.5$, 114.3, 95.3, 84.7, 76.7, 75.5, 56.4, 56.1, 51.1, 32.3, 32.1, 25.7, 24.0; IR ( $\left.v_{\max }, \mathrm{cm}^{-1}\right) 2937(\mathrm{~m})$, 2853 (w), 2108 (m), 1714 (m), 1595 (w), 1506 (m), 1444 (w), 1370 (m), 1337 (m), 1263 (s), 1207 (s), 1177 (s), 1111 (w), 1028 (m), 917 (m), 762 (m); HRMS (ESI/QTOF) m/z: [M + $\mathrm{Na}]^{+}$Calcd for $\mathrm{C}_{23} \mathrm{H}_{23} \mathrm{INaO}_{4} \mathrm{~S}^{+}$545.0254; Found 545.0270.

\section{Addition of an external nucleophile}

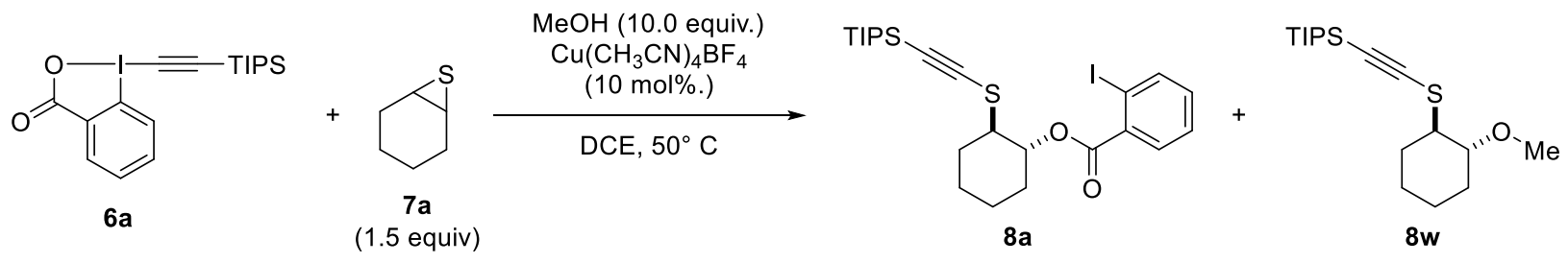

To a microwave vial containing TIPS-EBX (6a) $(43.0 \mathrm{mg}, 0.100 \mathrm{mmol}, 1.0$ equiv.) was added $\mathrm{Cu}\left(\mathrm{CH}_{3} \mathrm{CN}\right)_{4} \mathrm{BF}_{4}\left(3.2 \mathrm{mg}, 0.010 \mathrm{mmol}, 0.1\right.$ equiv.) under $\mathrm{N}_{2}$ atmosphere. The vial was sealed then DCE (1.5 mL), cyclohexene sulfide (7a) $(16 \mu \mathrm{L}, 0.15 \mathrm{mmol}, 1.5$ equiv.) and $\mathrm{MeOH}(41$ $\mu \mathrm{L}, 1.0 \mathrm{mmol}, 10.0$ equiv.) were added under $\mathrm{N}_{2}$ atmosphere. The reaction was stirred at $50{ }^{\circ} \mathrm{C}$ for $3 \mathrm{~h}$. The reaction was cooled to rt and concentrated in vacuo. The crude oil was purified by column chromatography (Toluene/Pentane; 1:4) to afford 8a (25 mg, $0.046 \mathrm{mmol}, 46 \%$ ) and 8w (5.0 mg, $0.016 \mathrm{mmol}, 16 \%$ ) as a colorless oil. 8w: $\mathrm{R}_{\mathrm{f}} 0.21$ (Toluene/Pentane; 3:7); ${ }^{1} \mathrm{H}$ NMR (400 MHz, Chloroform-d) $\delta 3.44$ (s, 3H, $\left.\mathrm{OCH}_{3}\right), 3.20$ (td, $\left.J=9.2,4.3 \mathrm{~Hz}, 1 \mathrm{H}, \mathrm{OCH}\right), 2.75-$ $2.65(\mathrm{~m}, 1 \mathrm{H}, \mathrm{SCH}), 2.25-2.14\left(\mathrm{~m}, 2 \mathrm{H}, \mathrm{CH}_{2}\right.$ cyclohexyl), $1.82-1.65\left(\mathrm{~m}, 3 \mathrm{H}, \mathrm{CH}_{2}\right.$ cyclohexyl), $1.38-1.18$ (m, 3H, CH 2 cyclohexyl), $1.11-1.03$ (m, 21H, TIPS); ${ }^{13} \mathrm{C}$ NMR (100 MHz, Chloroform- $d$ ) $\delta$ 99.0, 94.1, 80.3, 57.4, 51.8, 31.9, 31.0, 25.6, 24.0, 18.8, 11.5; IR $\left(v_{\max }, \mathrm{cm}^{-1}\right)$ 2935 (s), 2862 (s), 2088 (s), 1738 (s), 1529 (s), 1461 (m), 1451 (m), 1349 (m), 1263 (s), 1243 (s), 1118 (s), 1099 (s), 1019 (s), 858 (s), 737 (s), 676 (s), 660 (s); HRMS (ESI/QTOF) m/z: [M $+\mathrm{Ag}]^{+}$Calcd for $\mathrm{C}_{18} \mathrm{H}_{34} \mathrm{AgOSSi}^{+}$433.1145; Found 433.1155 . 
<smiles>O=C1OI(C#C[In])c2ccc([N+](=O)[O-])cc21</smiles>

$6 r$

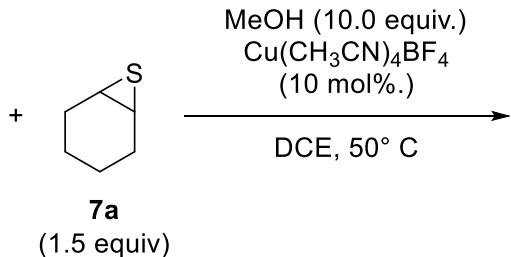<smiles>CO[C@H]1CCCCC1SC#CS[13C](=O)c1ccc(I)c(C(=O)O[C@H]2CCCC[C@@H]2SC#CSC(C)C)c1</smiles>

To a microwave vial containing 5-Nitro-1-[(triisopropylsilyl)ethynyl]-1,2-benziodoxol-3(1H)one (6r) (47.0 mg, $0.100 \mathrm{mmol}, 1.0$ equiv.) was added $\mathrm{Cu}\left(\mathrm{CH}_{3} \mathrm{CN}\right)_{4} \mathrm{BF}_{4}(3.2 \mathrm{mg}, 0.010 \mathrm{mmol}$, 0.1 equiv.) under $\mathrm{N}_{2}$ atmosphere. The vial was sealed then DCE (1.5 mL), cyclohexene sulfide (7a) $(16 \mu \mathrm{L}, 0.15 \mathrm{mmol}, 1.5$ equiv.) and $\mathrm{MeOH}(41 \mu \mathrm{L}, 1.0 \mathrm{mmol}, 10.0$ equiv.) were added under $\mathrm{N}_{2}$ atmosphere. The reaction was stirred at $50{ }^{\circ} \mathrm{C}$ for $3 \mathrm{~h}$. The reaction was cooled to $\mathrm{rt}$ and concentrated in vacuo. Based on the crude NMR using dibromomethane as internal standard we obtained $8 \mathbf{r}(37 \%)$ and $\mathbf{8 w}(17 \%)$.

\section{Crystal structure of 8a}

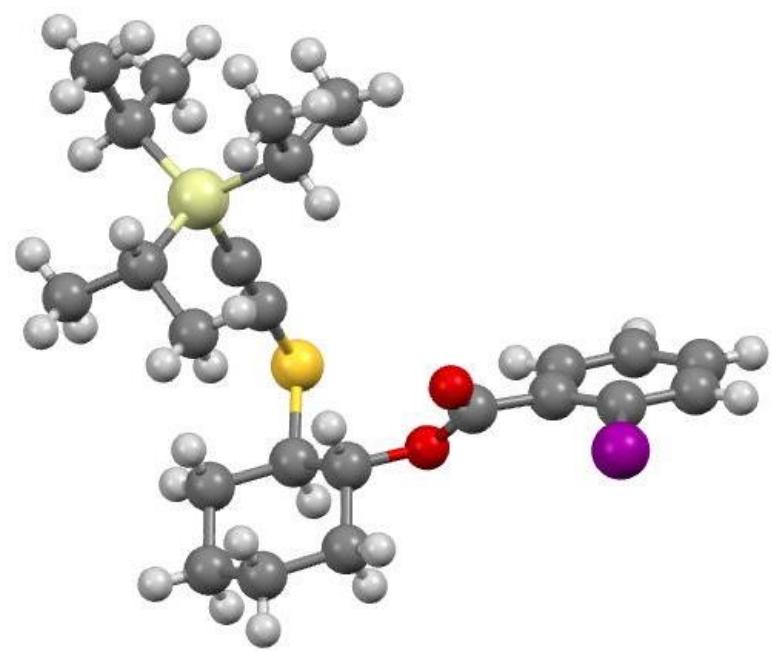

Crystals were grown by storing a large $(1 \mathrm{~g})$ batch of $\mathbf{8 a}$ in the freezer $\left(-5^{\circ} \mathrm{C}\right)$ for an extensive period of time. Supplementary crystallographic data for this compound have been deposited at Cambridge Crystallographic Data Centre (CCDC 1962904) and can be obtained free of charge via www.ccdc.cam.ac.uk/data_request/cif.

\section{Spectra of new compounds}


${ }^{1} \mathrm{H}$ NMR (400 MHz, $\mathrm{CDCl}_{3}$ ) of compound $\mathbf{6 s :}$

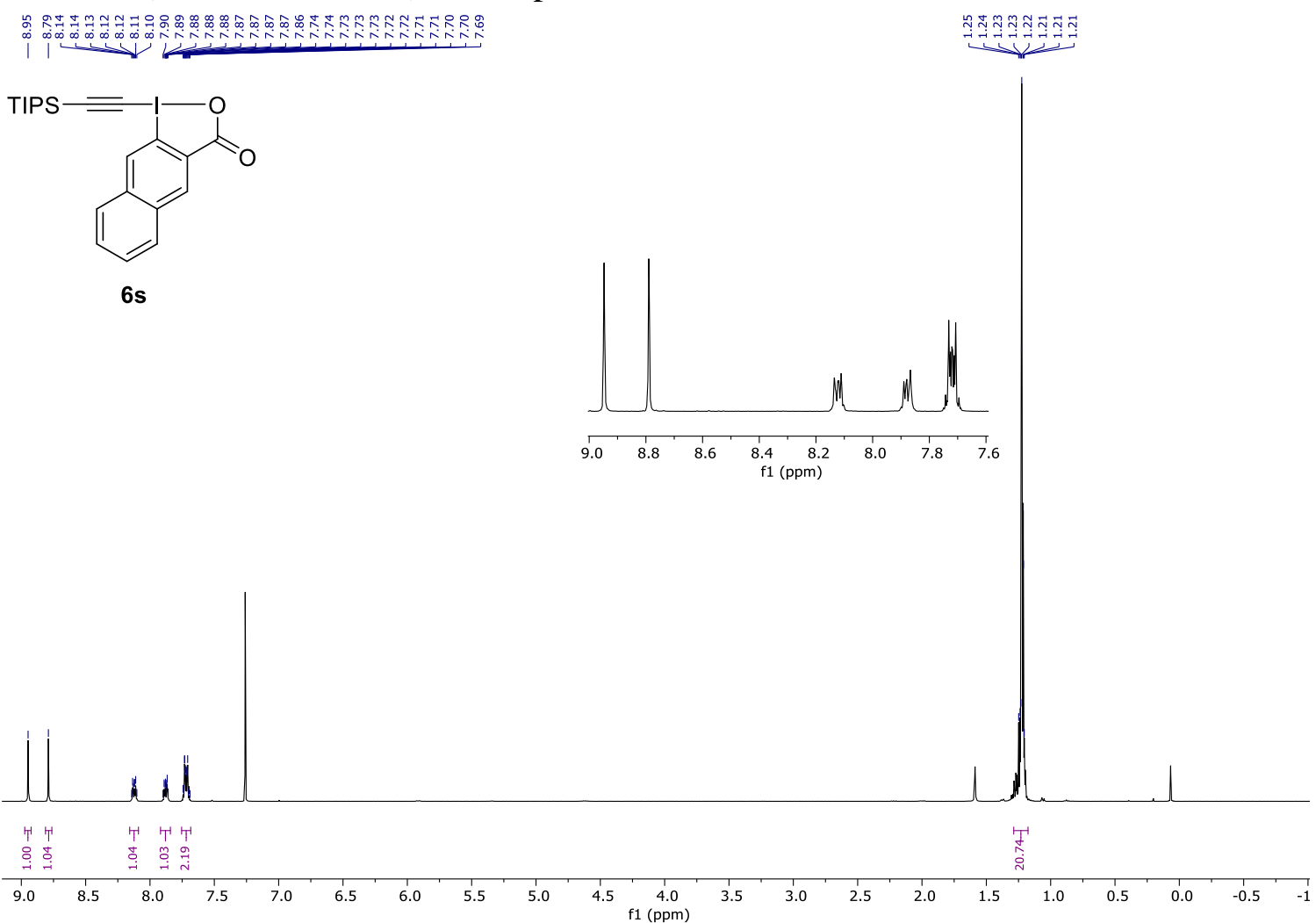

${ }^{13} \mathrm{C} \mathrm{NMR}\left(100 \mathrm{MHz}, \mathrm{CDCl}_{3}\right)$ of compound $\mathbf{6 s}$ :

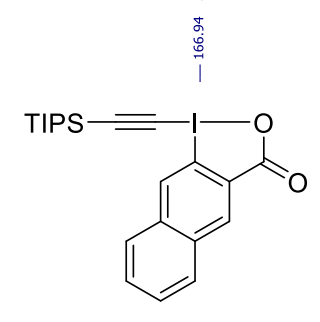

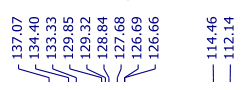

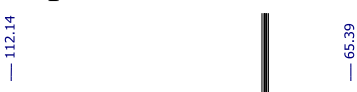

$6 s$

i

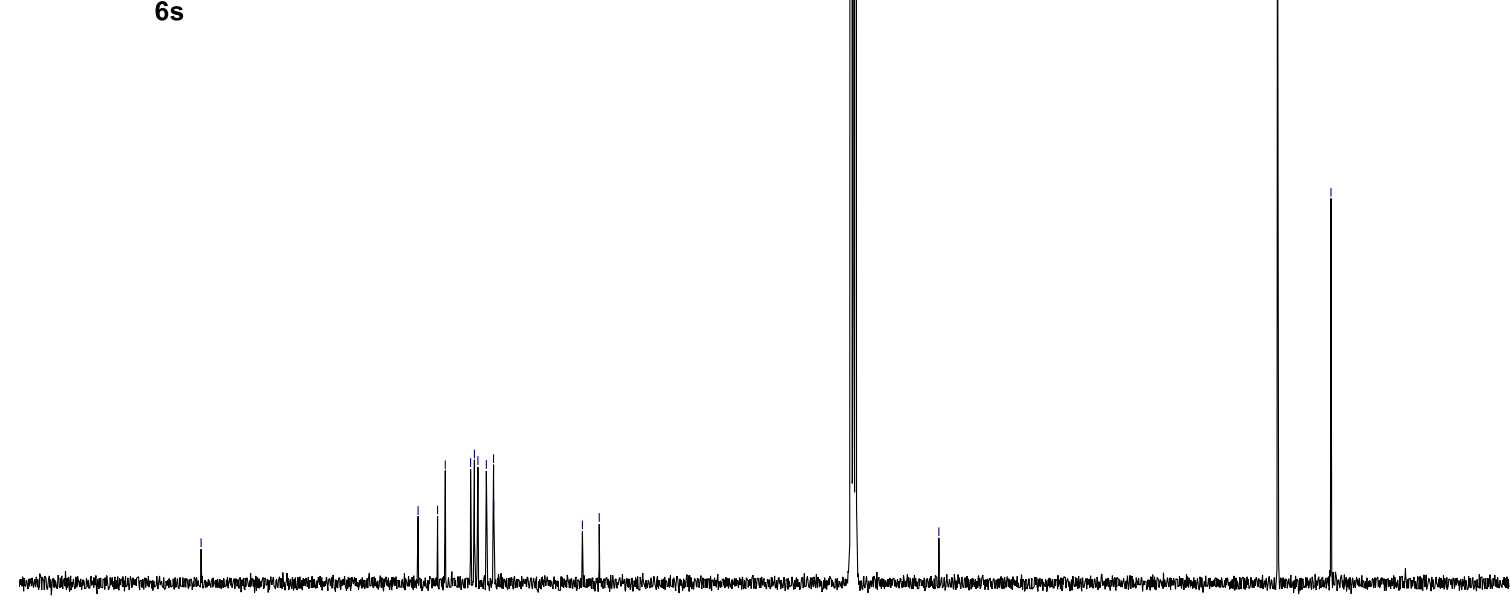

190

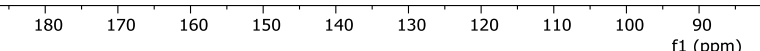


${ }^{1} \mathrm{H}$ NMR (400 MHz, $\mathrm{CDCl}_{3}$ ) of compound 7c:

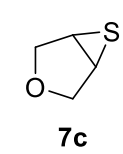

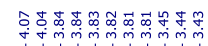

$7 c$

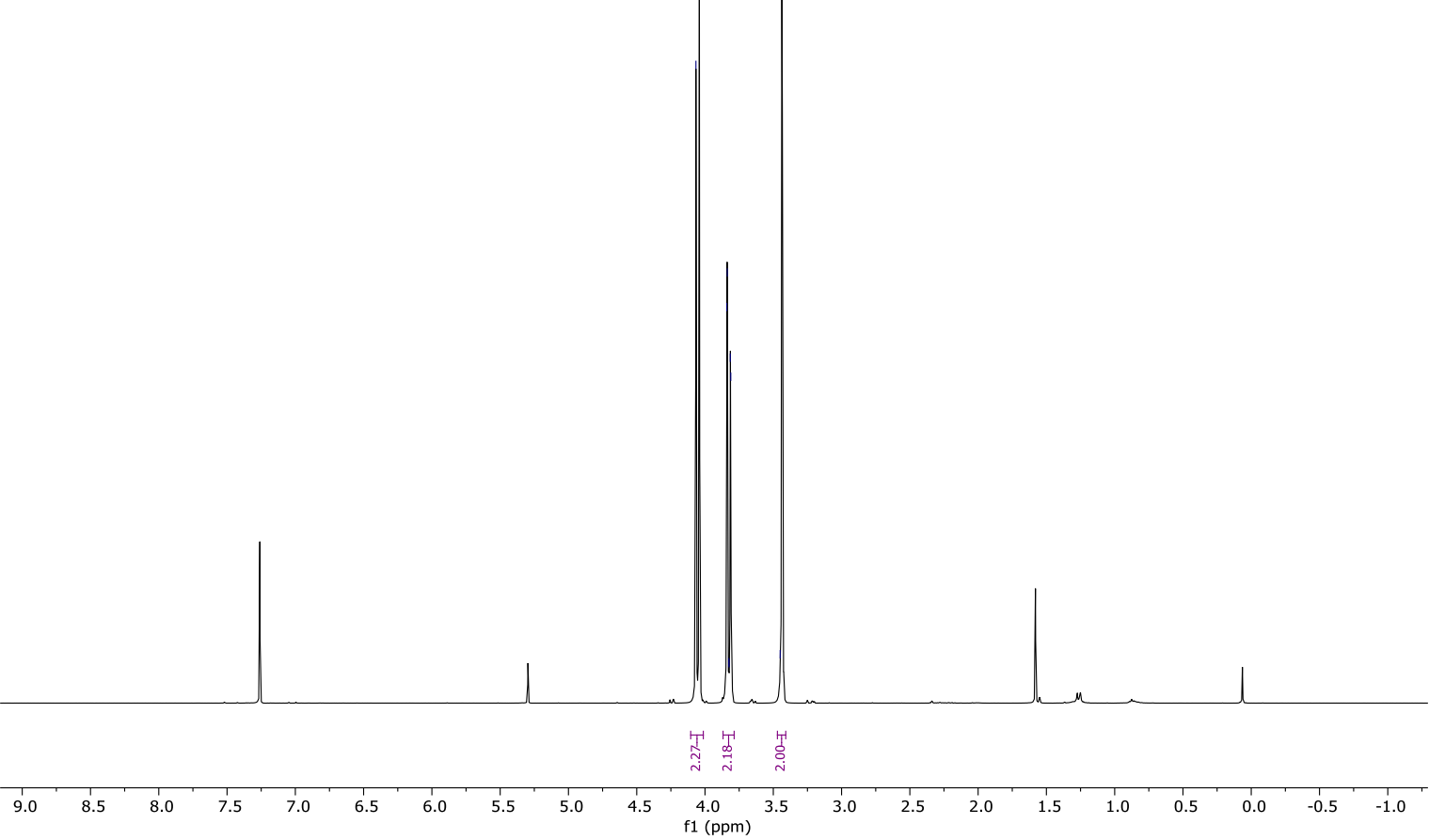

${ }^{13} \mathrm{C}$ NMR $\left(100 \mathrm{MHz}, \mathrm{CDCl}_{3}\right)$ of compound $7 \mathbf{c}$ :
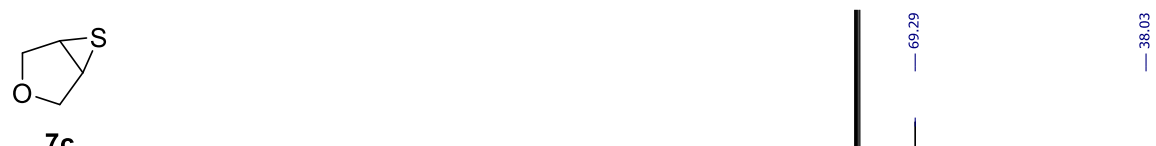

$7 \mathrm{c}$

$\begin{array}{lllllllllll}190 & 180 & 170 & 160 & 150 & 140 & 130 & 120 & 110 & 100 & 90\end{array}$ 
${ }^{1} \mathrm{H}$ NMR (400 MHz, $\mathrm{CDCl}_{3}$ ) of compound 7d:

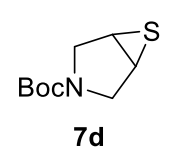

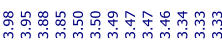

$\stackrel{1}{2}$

$7 d$

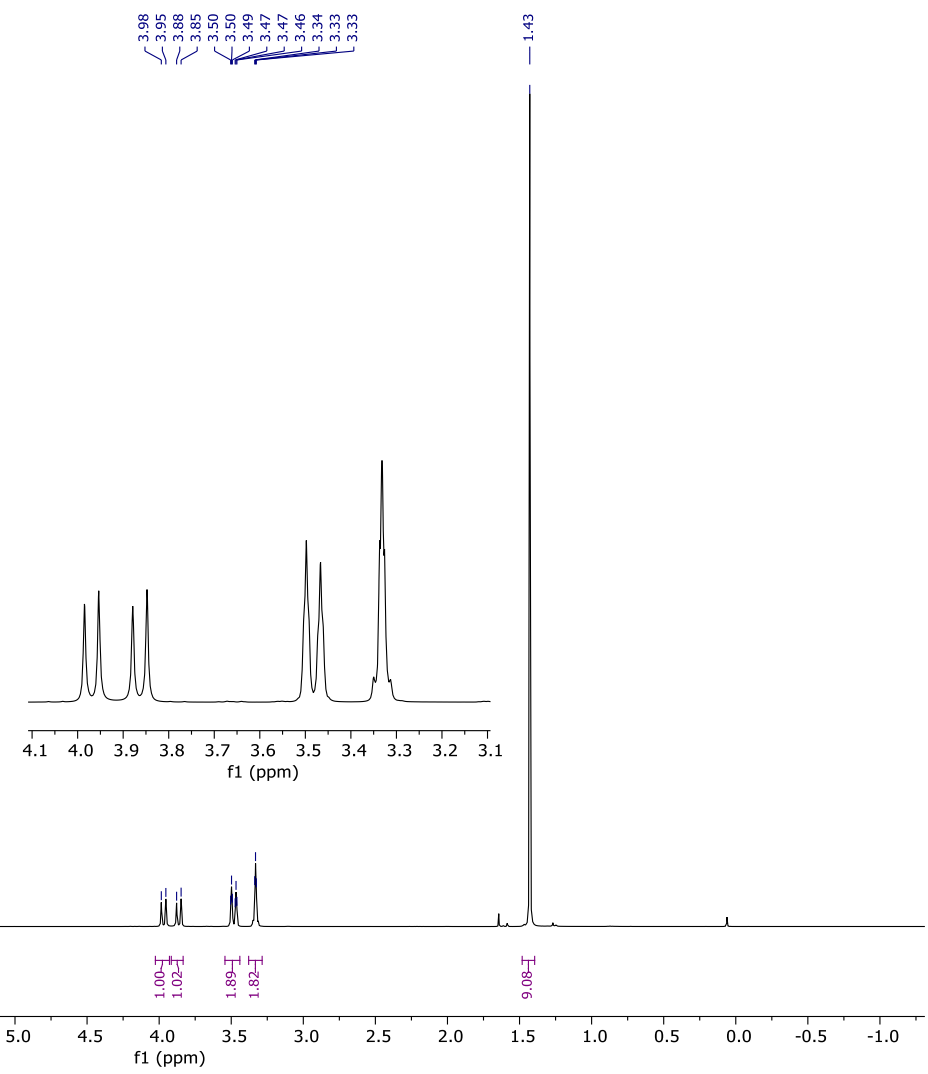

${ }^{13} \mathrm{C} \mathrm{NMR}\left(100 \mathrm{MHz}, \mathrm{CDCl}_{3}\right)$ of compound $\mathbf{7 d}$ :
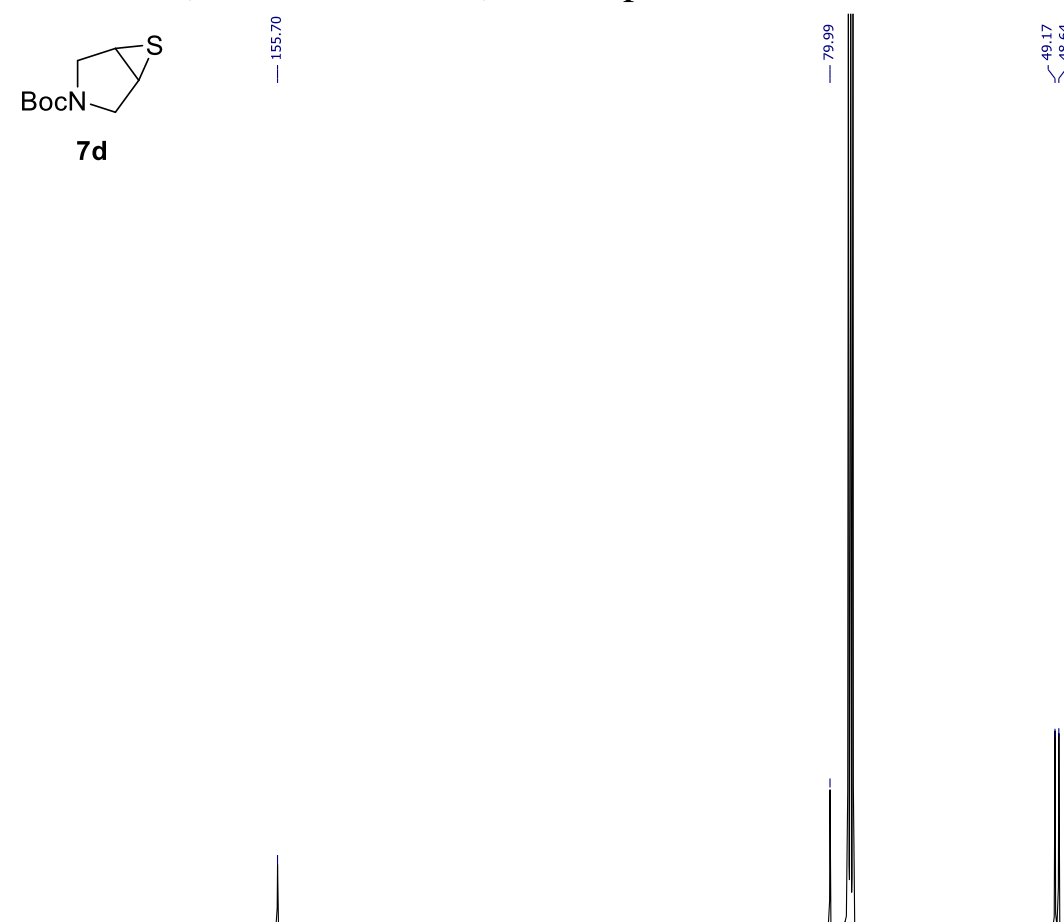
${ }^{1} \mathrm{H} \mathrm{NMR}\left(400 \mathrm{MHz}, \mathrm{CDCl}_{3}\right)$ of compound $7 \mathbf{g}$ :

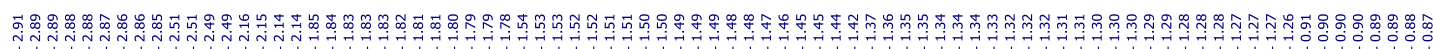

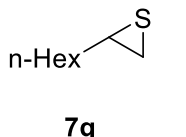

$7 \mathrm{~g}$

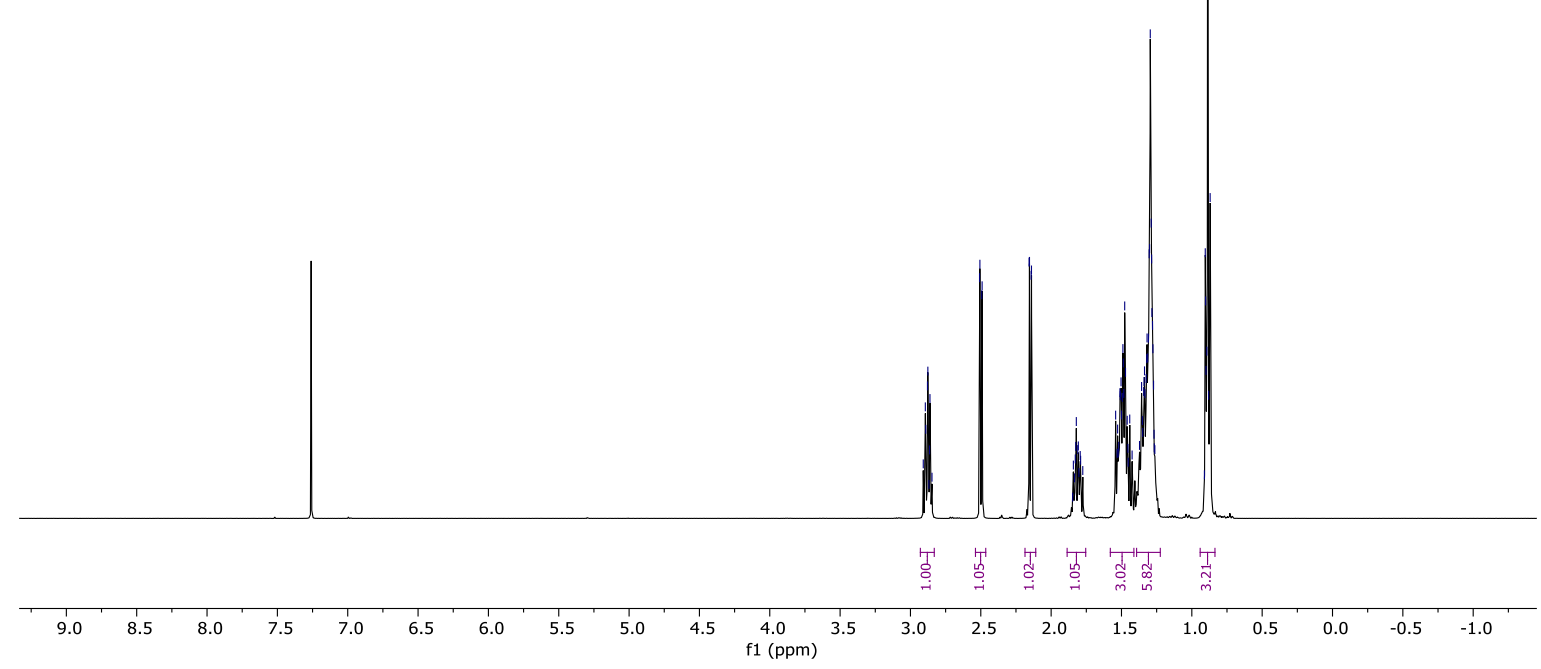

${ }^{13} \mathrm{C}$ NMR $\left(100 \mathrm{MHz}, \mathrm{CDCl}_{3}\right)$ of compound $\mathbf{7 g}$ :

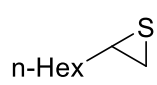

$7 \mathrm{~g}$

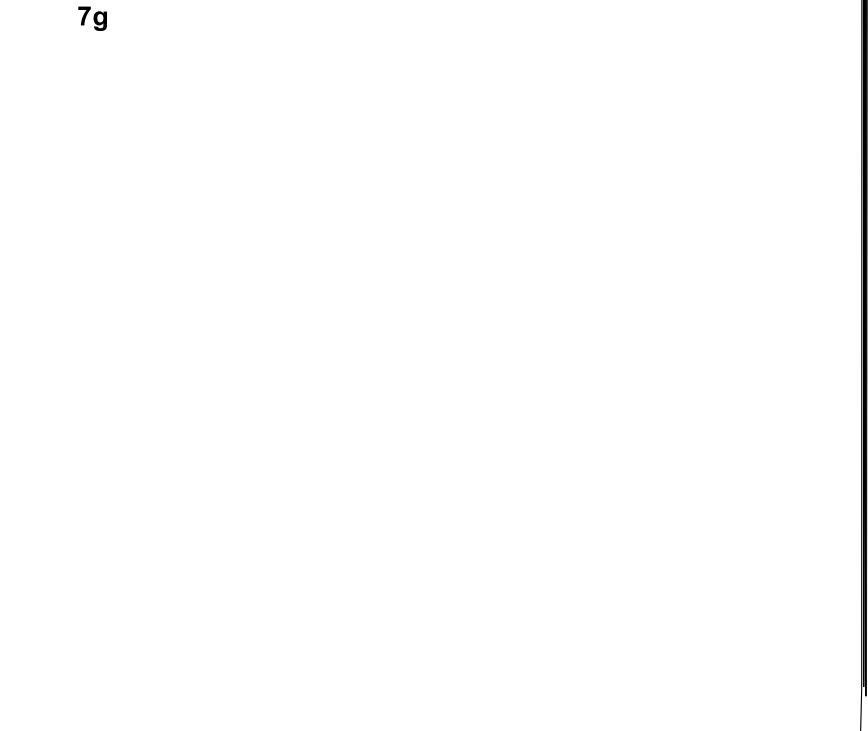

$\begin{array}{lllllllllll}190 & 180 & 170 & 160 & 150 & 140 & 130 & 120 & 110 & 100 & 90\end{array}$

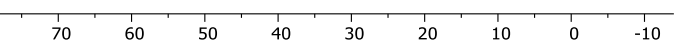


${ }^{1} \mathrm{H}$ NMR (400 MHz, $\mathrm{CDCl}_{3}$ ) of compound 7i:

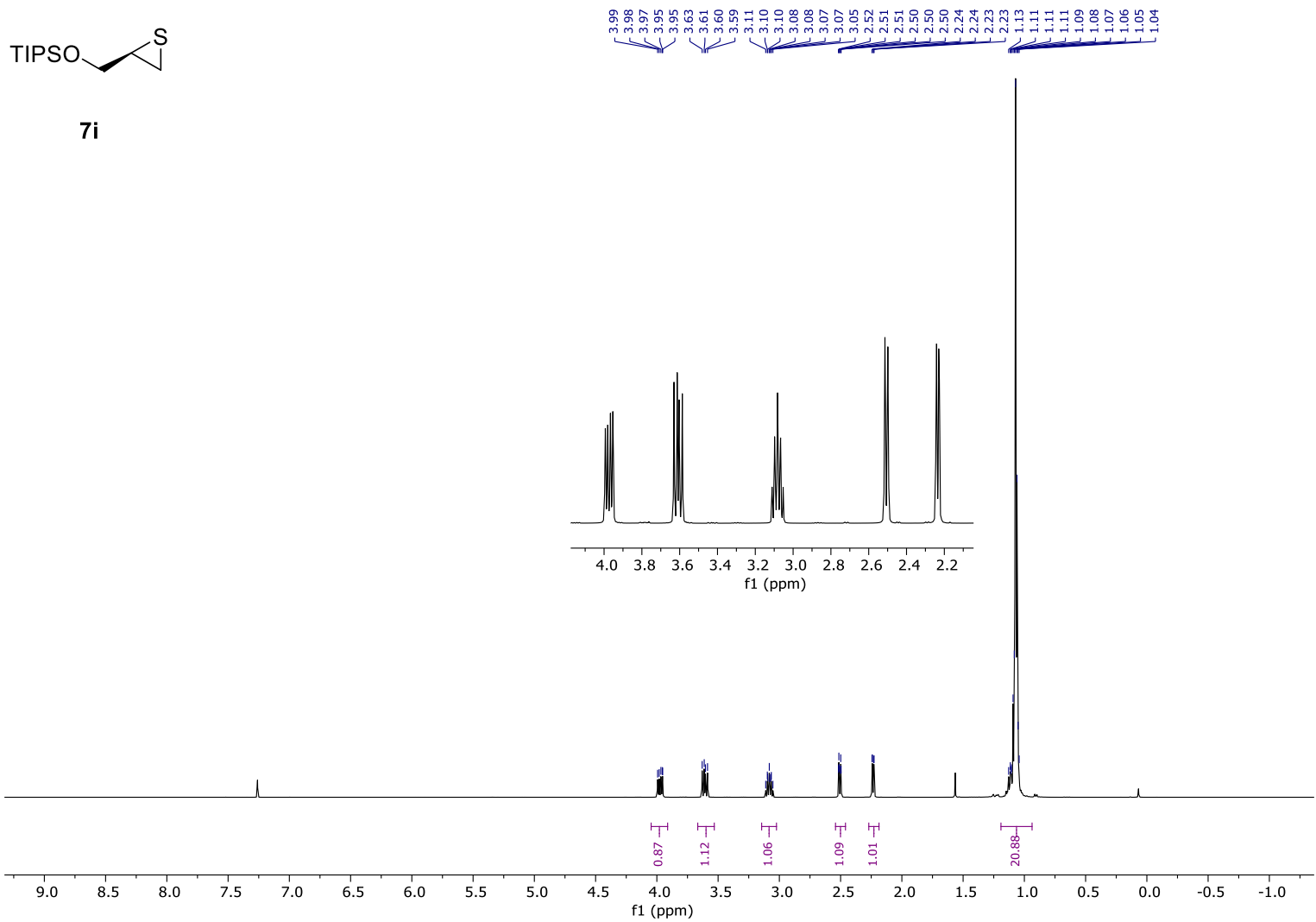

${ }^{13} \mathrm{C}$ NMR (100 MHz, $\mathrm{CDCl}_{3}$ ) of compound 7i:<smiles>C[AsH2]C[SiH3]</smiles>

$7 \mathbf{i}$

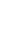

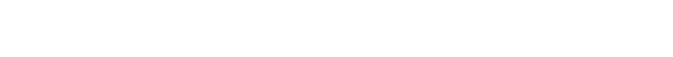


${ }^{1} \mathrm{H} \mathrm{NMR} \mathrm{(400} \mathrm{MHz,} \mathrm{CDCl}_{3}$ ) of compound 8a:

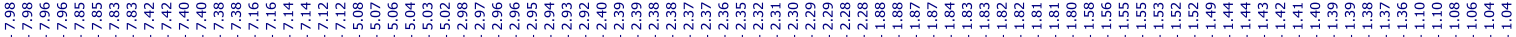<smiles>O=C(O[C@H]1CCCC[C@@H]1SC#C[In])c1ccccc1I</smiles>

$8 \mathbf{a}$

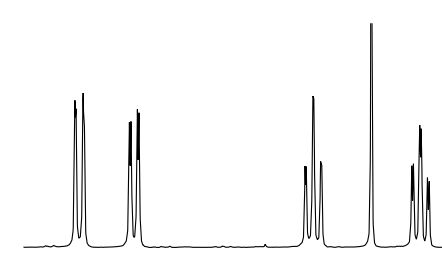

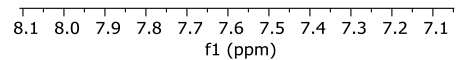

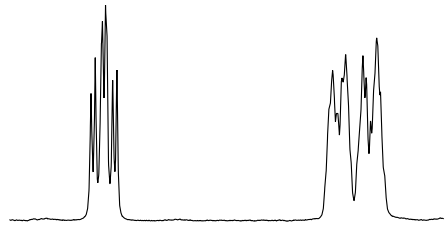

$\begin{array}{lllllllllllll}3.1 & 3.0 & 2.9 & 2.8 & 2.7 & 2.6 & 2.5 & 2.4 & 2.3 & 2.2\end{array}$

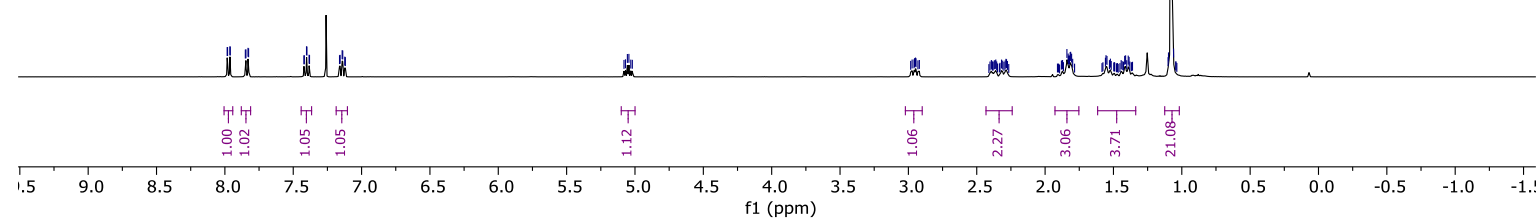

${ }^{13} \mathrm{C}$ NMR $\left(100 \mathrm{MHz}, \mathrm{CDCl}_{3}\right)$ of compound 8a:

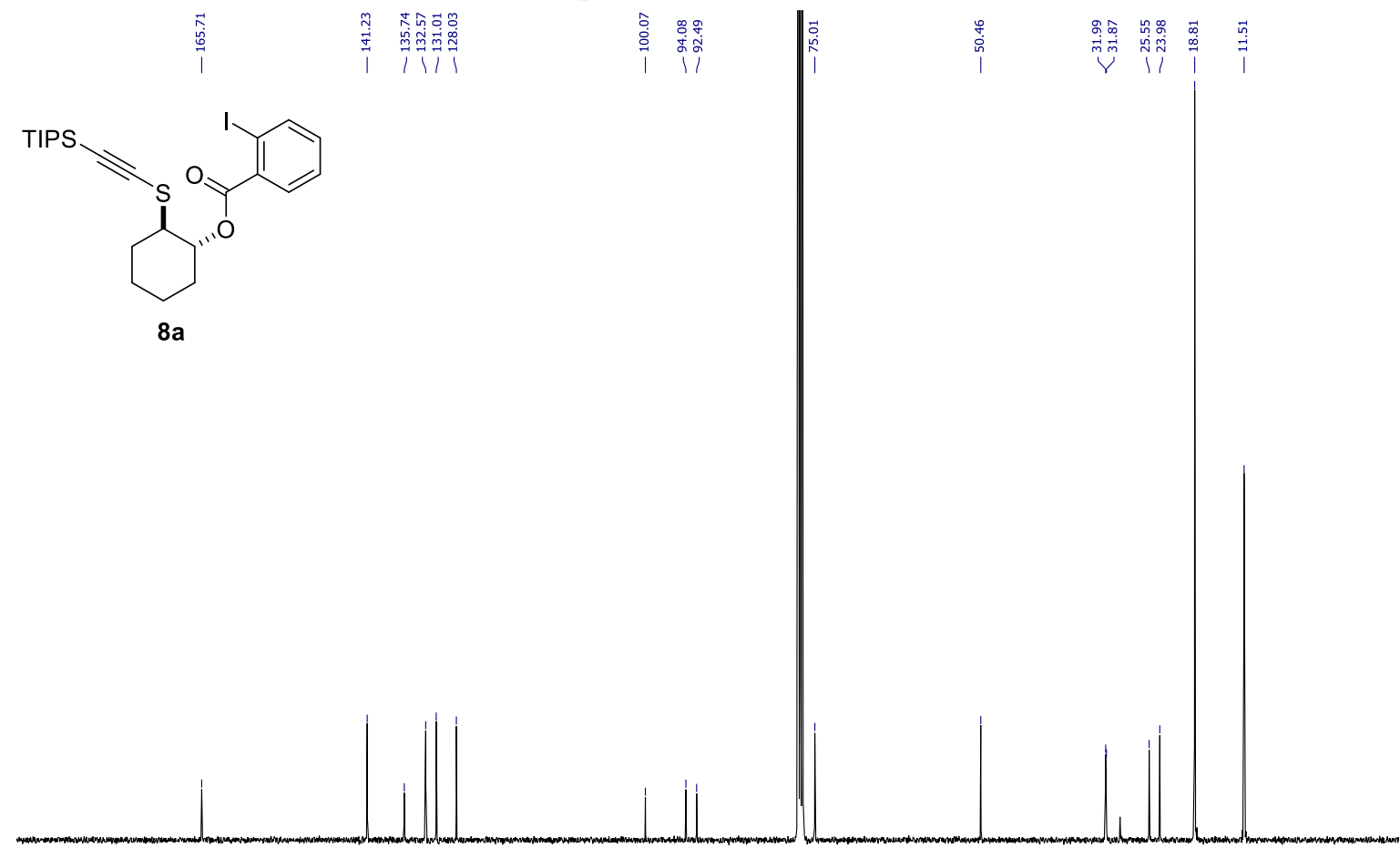

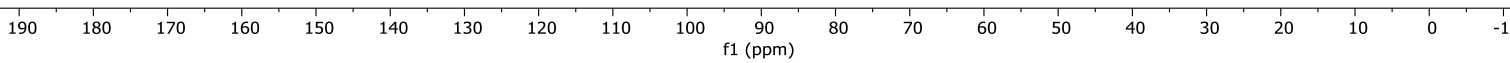


${ }^{1} \mathrm{H}$ NMR (400 MHz, $\mathrm{CDCl}_{3}$ ) of compound $\mathbf{8 b}$ :

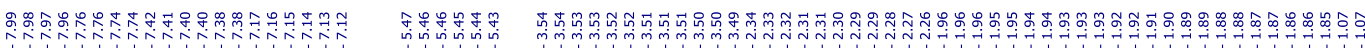<smiles>CC(C)C#CSC1CCCC1OC(=O)c1ccccc1I</smiles>

$8 b$
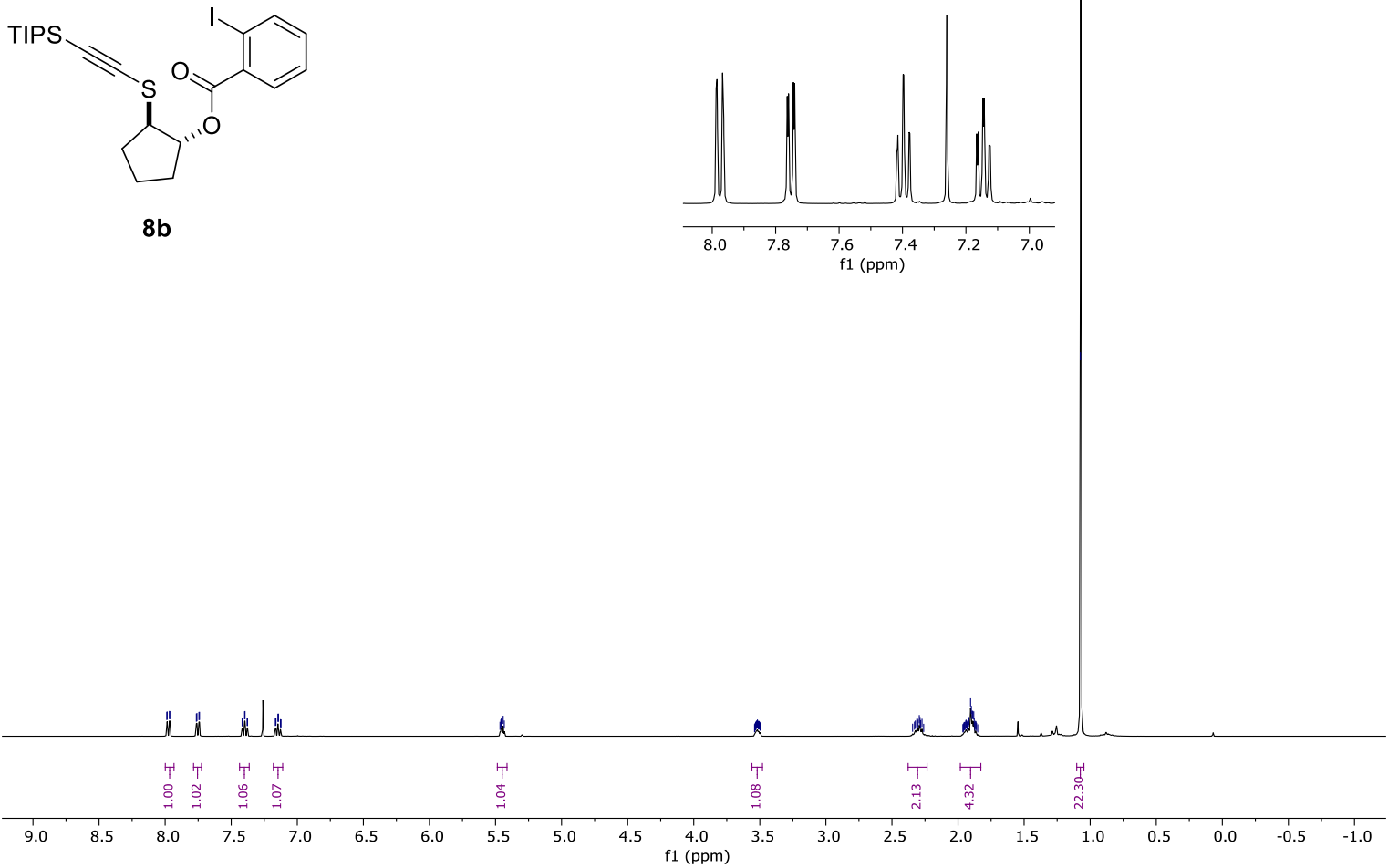

${ }^{13} \mathrm{C}$ NMR $\left(100 \mathrm{MHz}, \mathrm{CDCl}_{3}\right)$ of compound $\mathbf{8 b}$ :

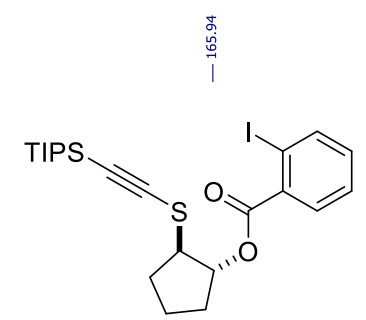

$8 b$
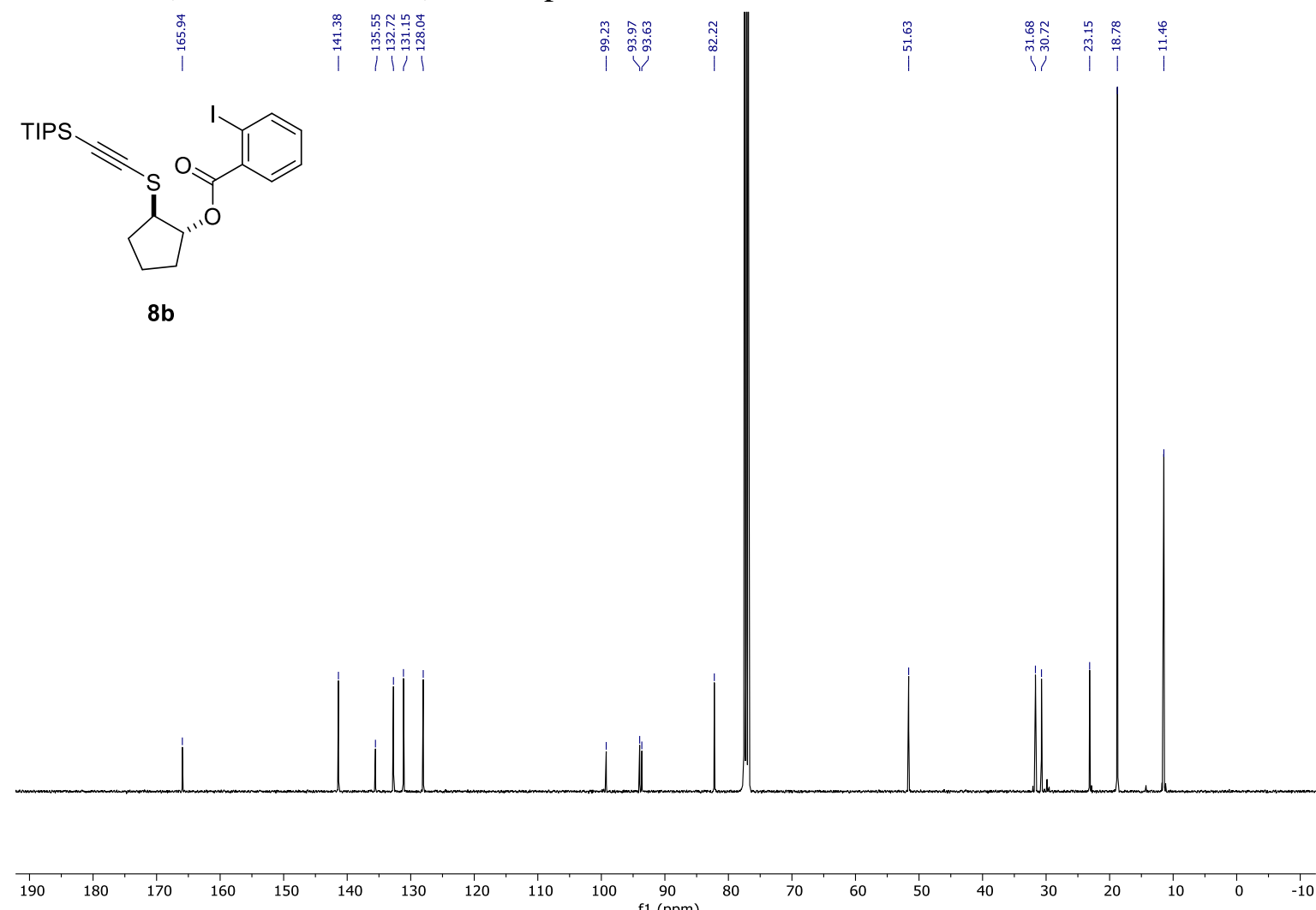
${ }^{1} \mathrm{H}$ NMR (400 MHz, $\mathrm{CDCl}_{3}$ ) of compound 8c:

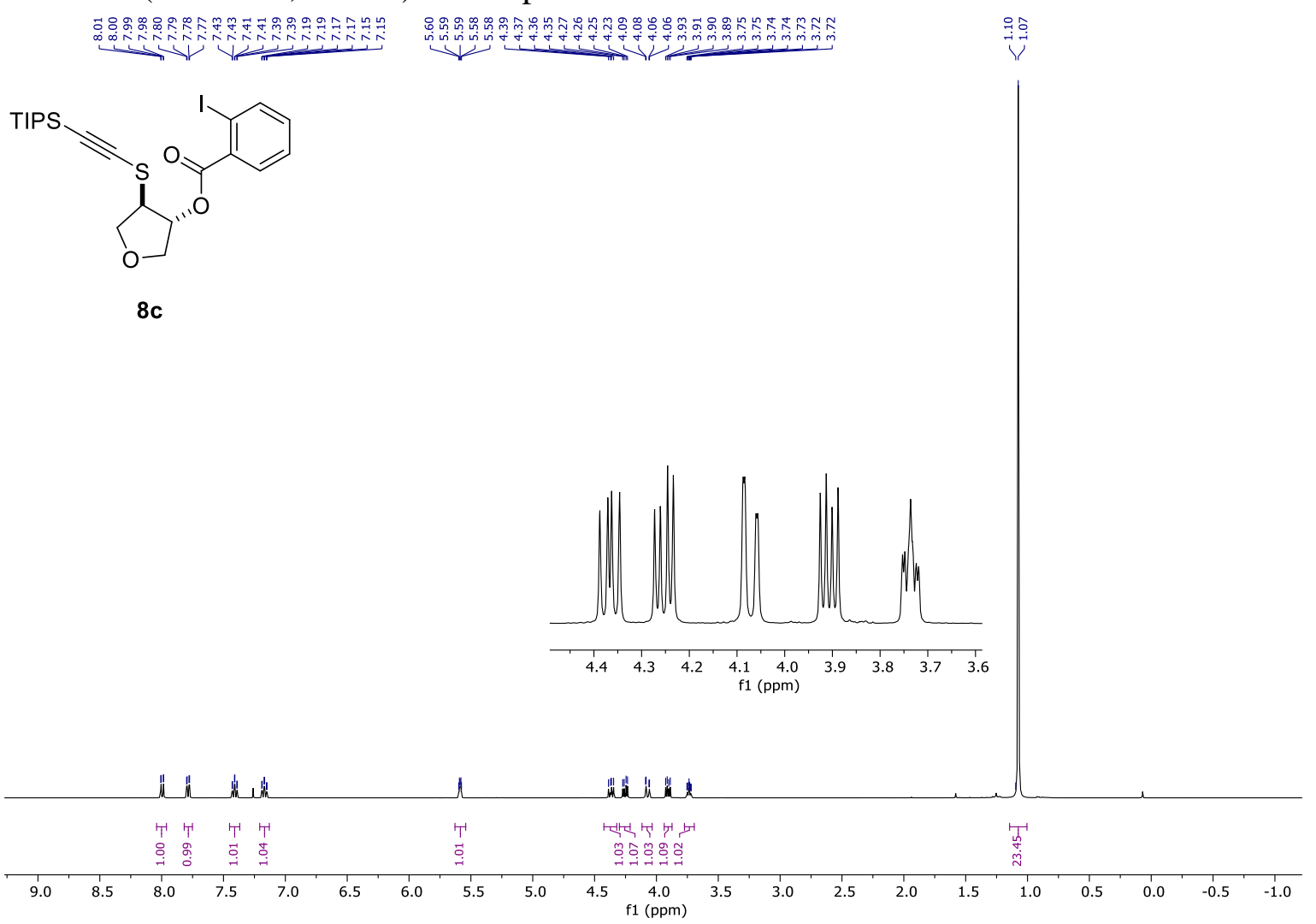

${ }^{13} \mathrm{C} \mathrm{NMR}\left(100 \mathrm{MHz}, \mathrm{CDCl}_{3}\right)$ of compound $8 \mathbf{c}$ :

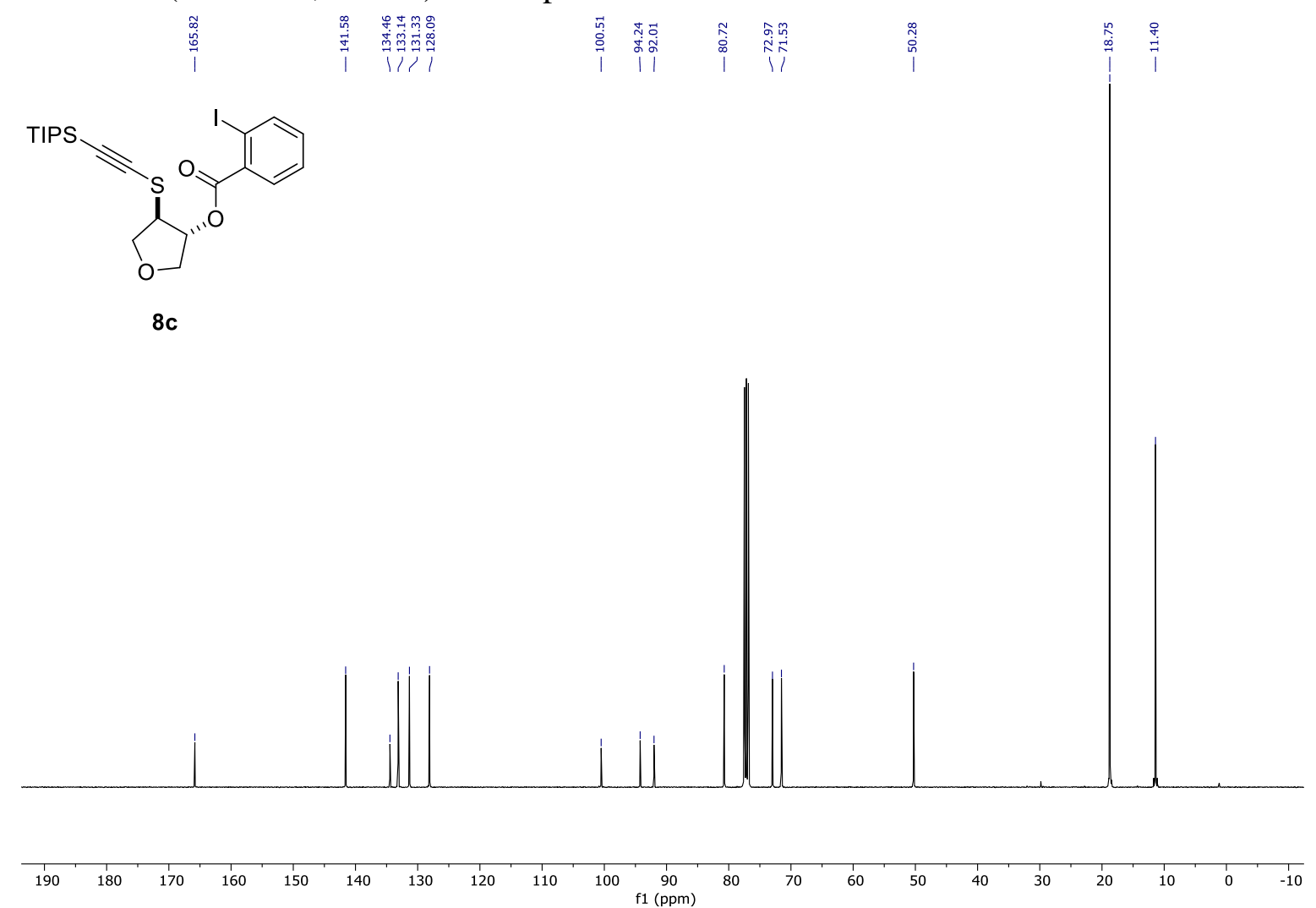


${ }^{1} \mathrm{H}$ NMR (400 MHz, $\mathrm{CDCl}_{3}$ ) of compound 8d:

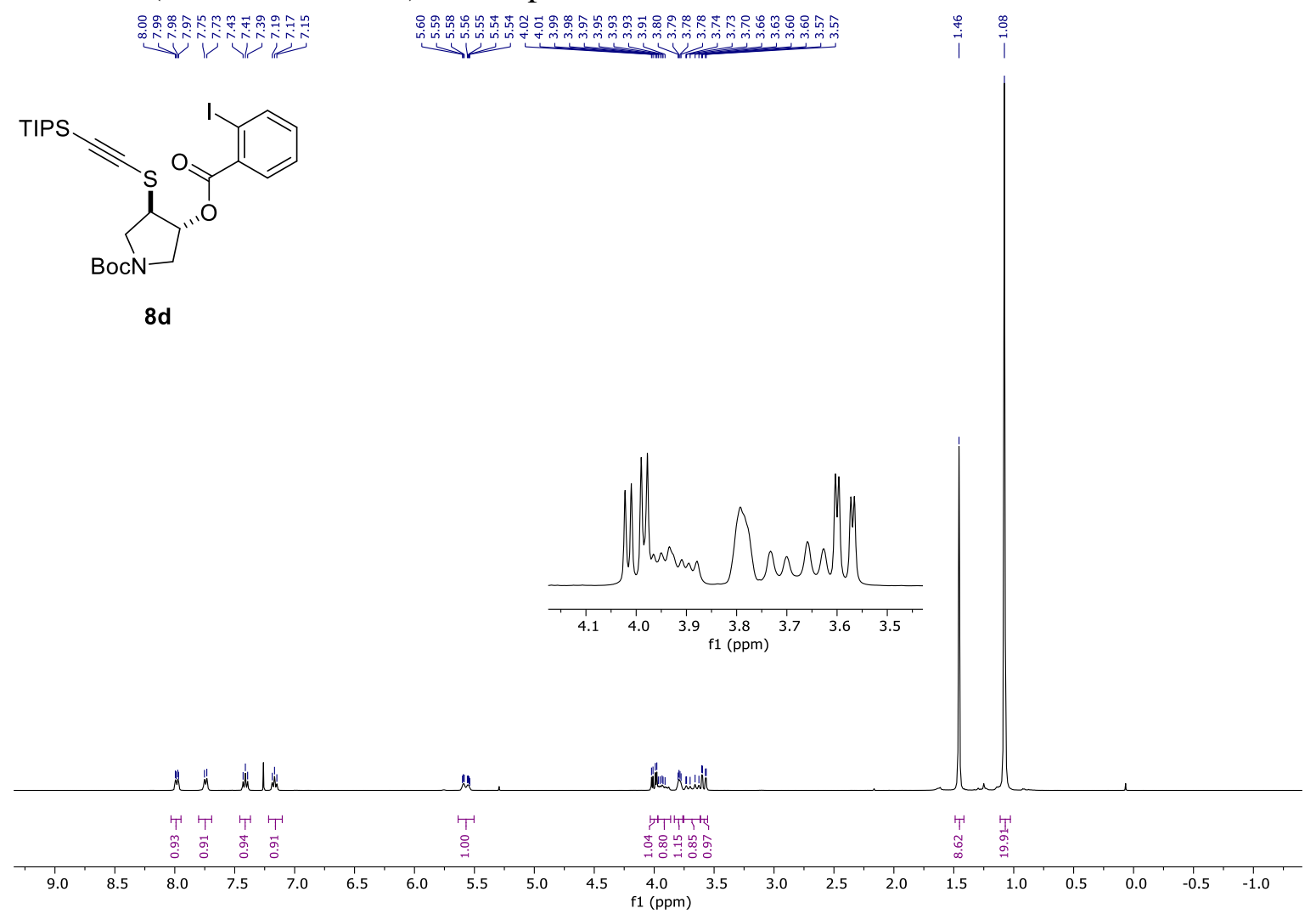

${ }^{13} \mathrm{C}$ NMR (100 MHz, $\left.\mathrm{CDCl}_{3}\right)$ of compound 8d:

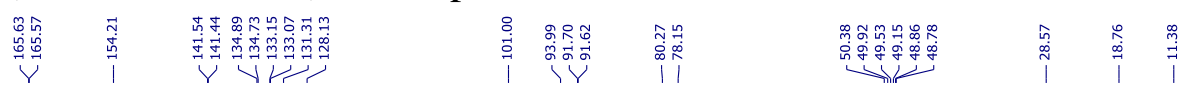<smiles>CC(C)(C)OC(=O)CSC#CSC1CN(C(C)(C)C)CC1OC(=O)c1ccccc1I</smiles>

$8 d$

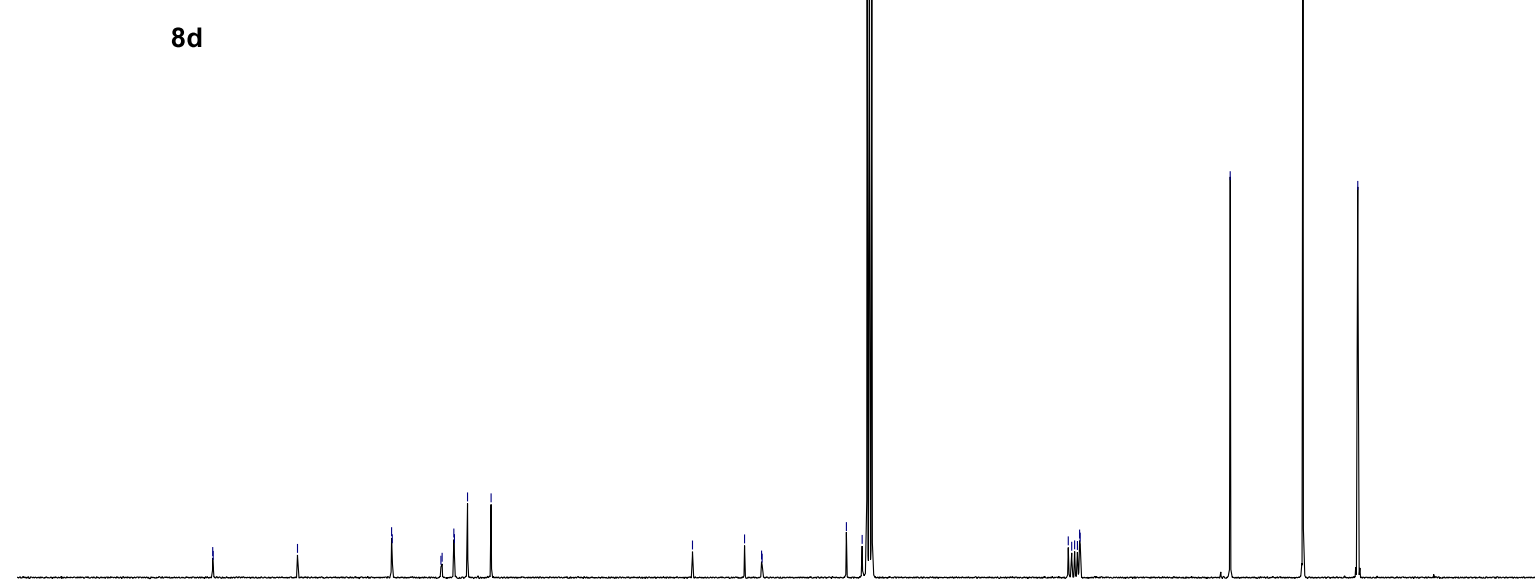

$\begin{array}{lllllllllll}190 & 180 & 170 & 160 & 150 & 140 & 130 & 120 & 110 & 100 & 90 \\ & & & & & & & & & \end{array}$ 
${ }^{1} \mathrm{H}$ NMR (400 MHz, $\mathrm{CDCl}_{3}$ ) of compound $\mathbf{8 e}$ :
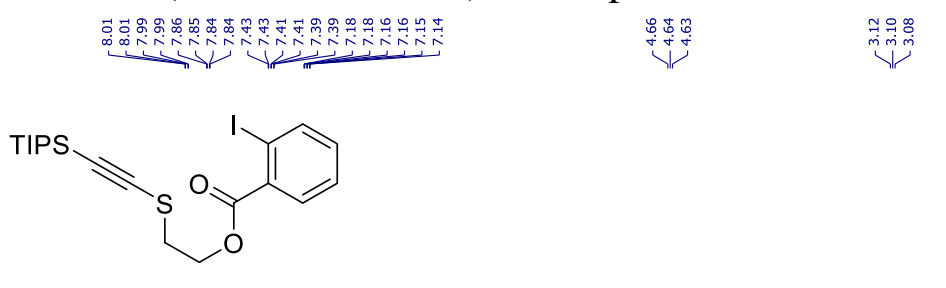

$8 e$

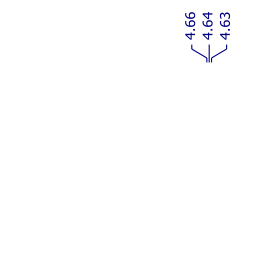

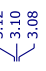
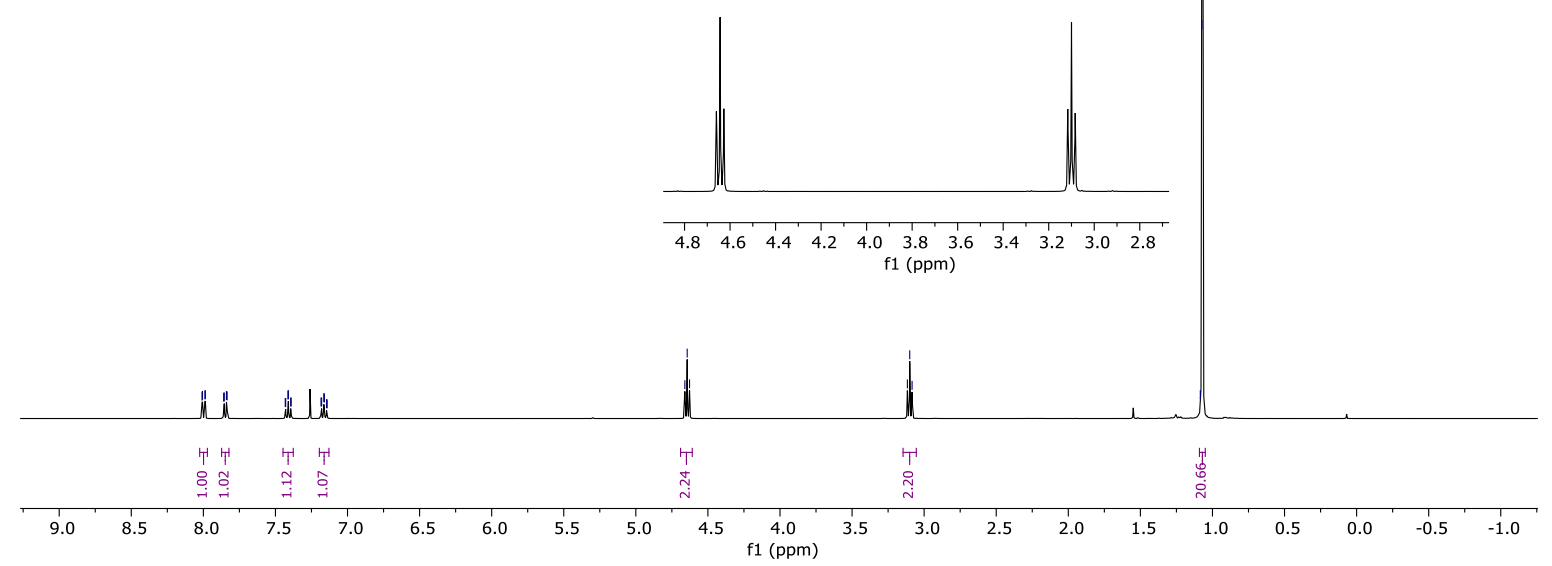

${ }^{13} \mathrm{C}$ NMR (100 MHz, $\mathrm{CDCl}_{3}$ ) of compound 8e:

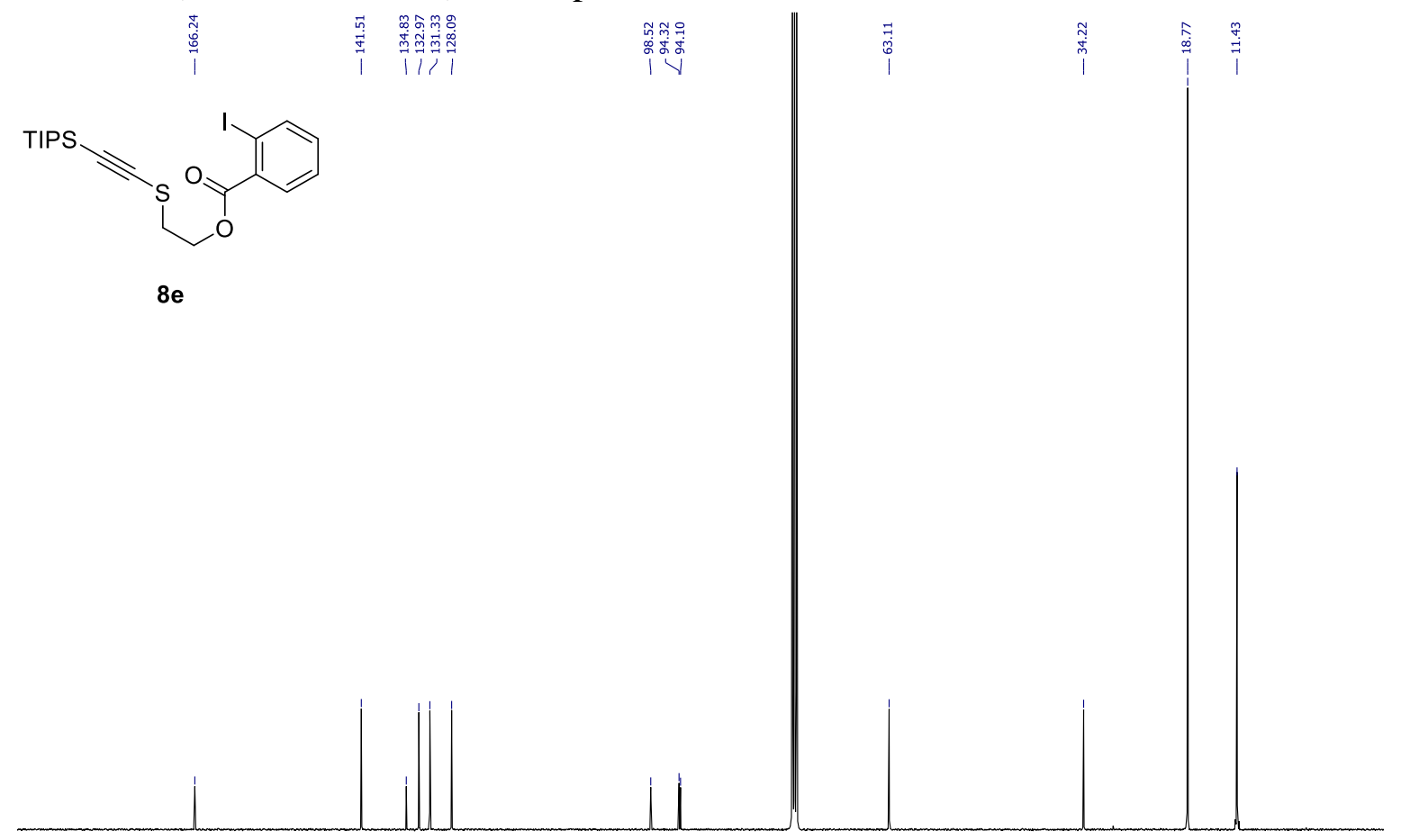

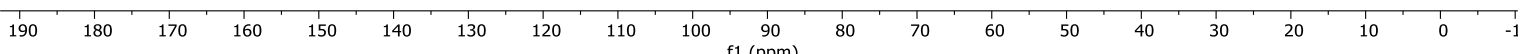


${ }^{1} \mathrm{H}$ NMR (400 MHz, $\mathrm{CDCl}_{3}$ ) of compound $\mathbf{8 f}$ and $\mathbf{8 f}$ ':

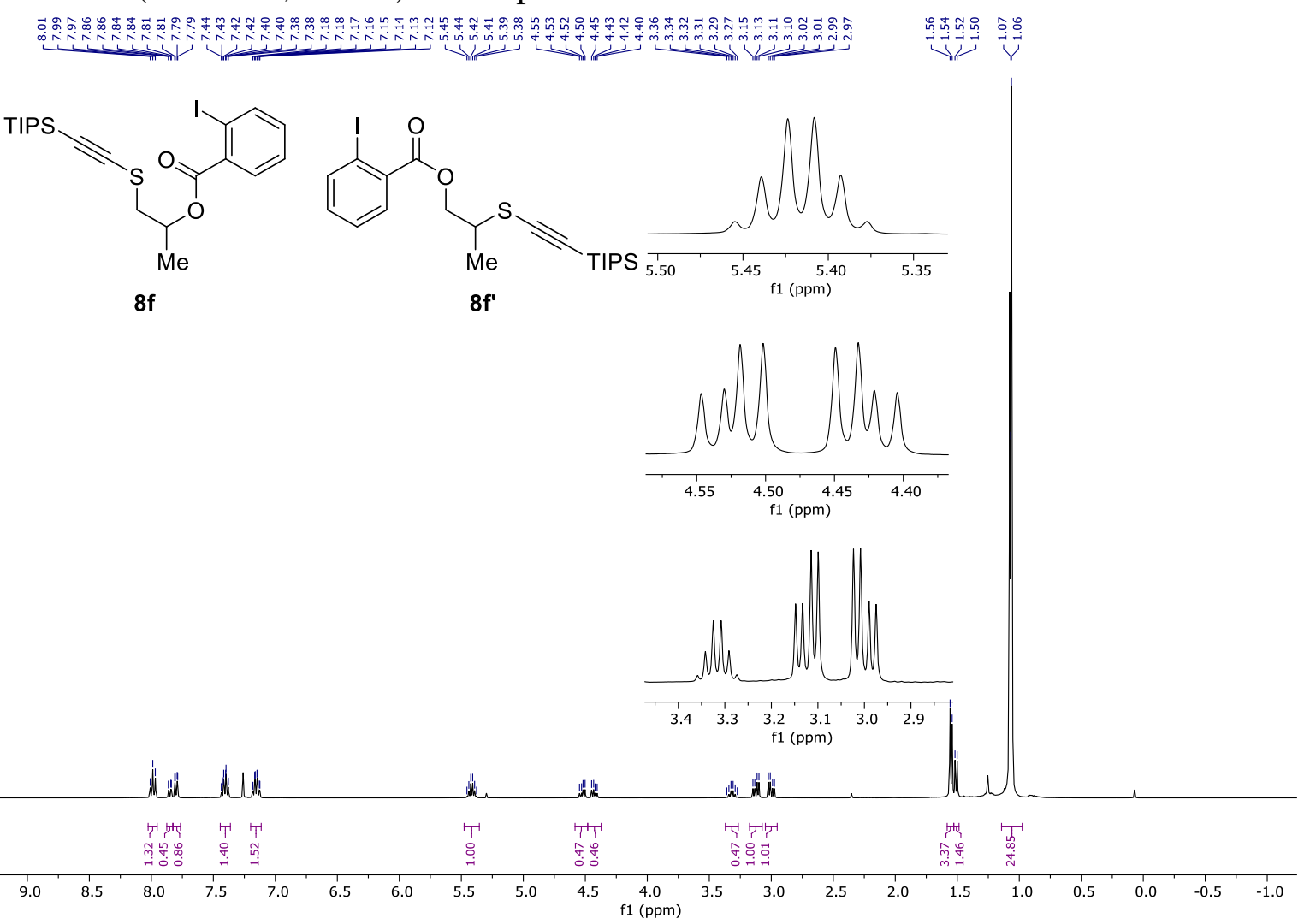

${ }^{13} \mathrm{C}$ NMR (100 MHz, $\mathrm{CDCl}_{3}$ ) of compound $\mathbf{8 f}$ and $\mathbf{8 f}$ ':

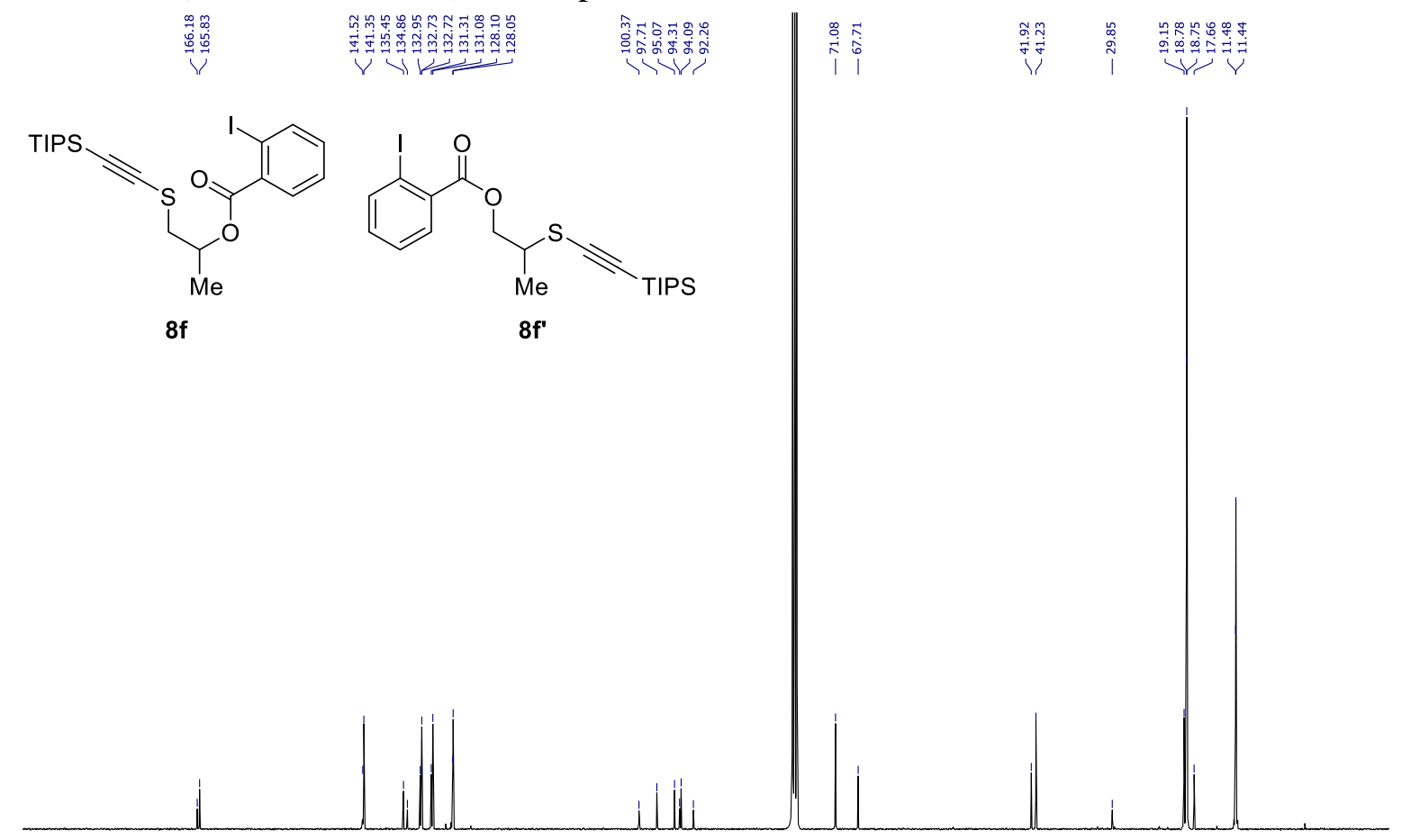

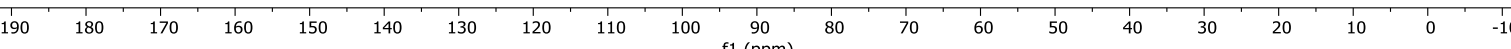


${ }^{1} \mathrm{H}$ NMR (400 MHz, $\mathrm{CDCl}_{3}$ ) of compound $\mathbf{8 g}$ and $\mathbf{8 g}$ ':

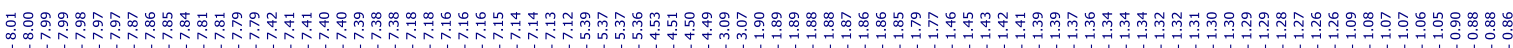<smiles>CCCCCCC(CSC#CS[In])OC(=O)c1ccccc1I</smiles>

$8 \mathrm{~g}$

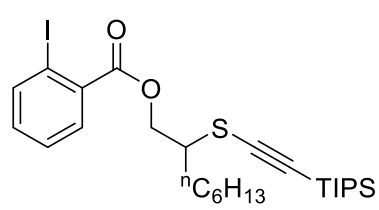

8g'

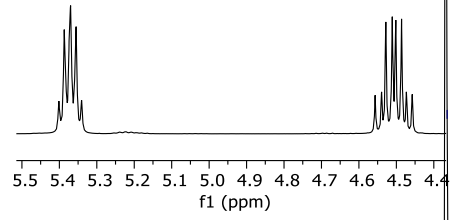

Hill int

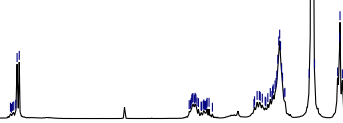

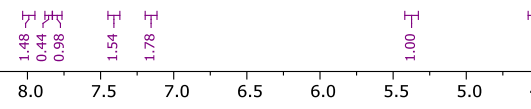

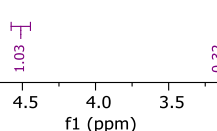

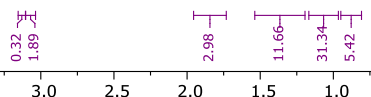

${ }^{13} \mathrm{C} \mathrm{NMR}\left(100 \mathrm{MHz}, \mathrm{CDCl}_{3}\right)$ of compound $\mathbf{8 g}$ and $\mathbf{8 g}$ ':

踾

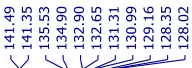

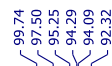

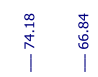
草 TIPS<smiles>CCC(CS)OC(=O)c1ccccc1I</smiles>

$8 \mathrm{~g}$

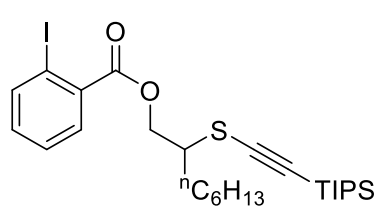

$8 \mathbf{g}^{\prime}$

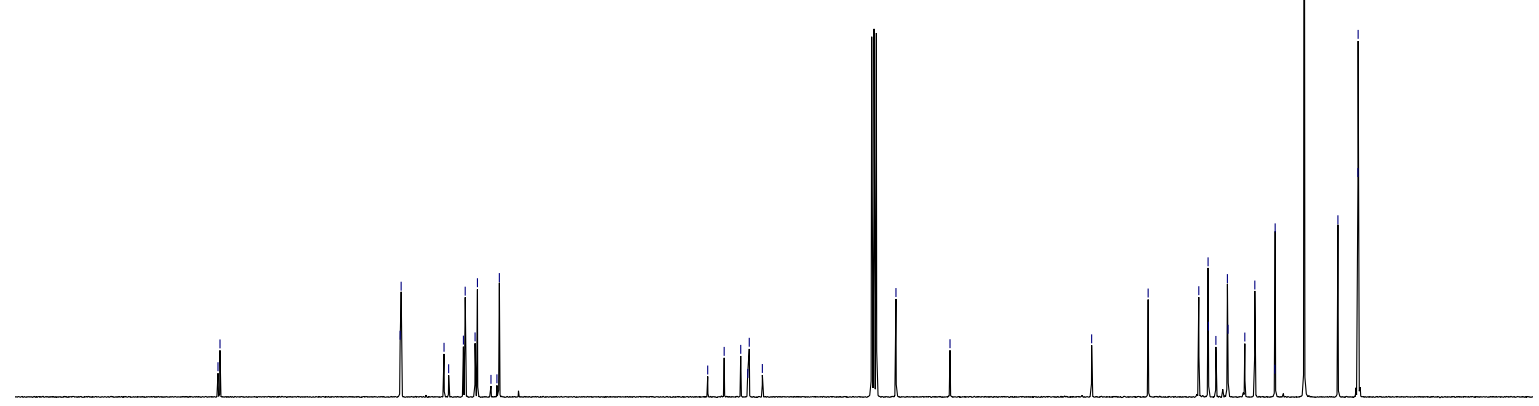


${ }^{1} \mathrm{H}$ NMR (400 MHz, $\mathrm{CDCl}_{3}$ ) of compound $\mathbf{8 h}$ and $\mathbf{8 h}$ ':

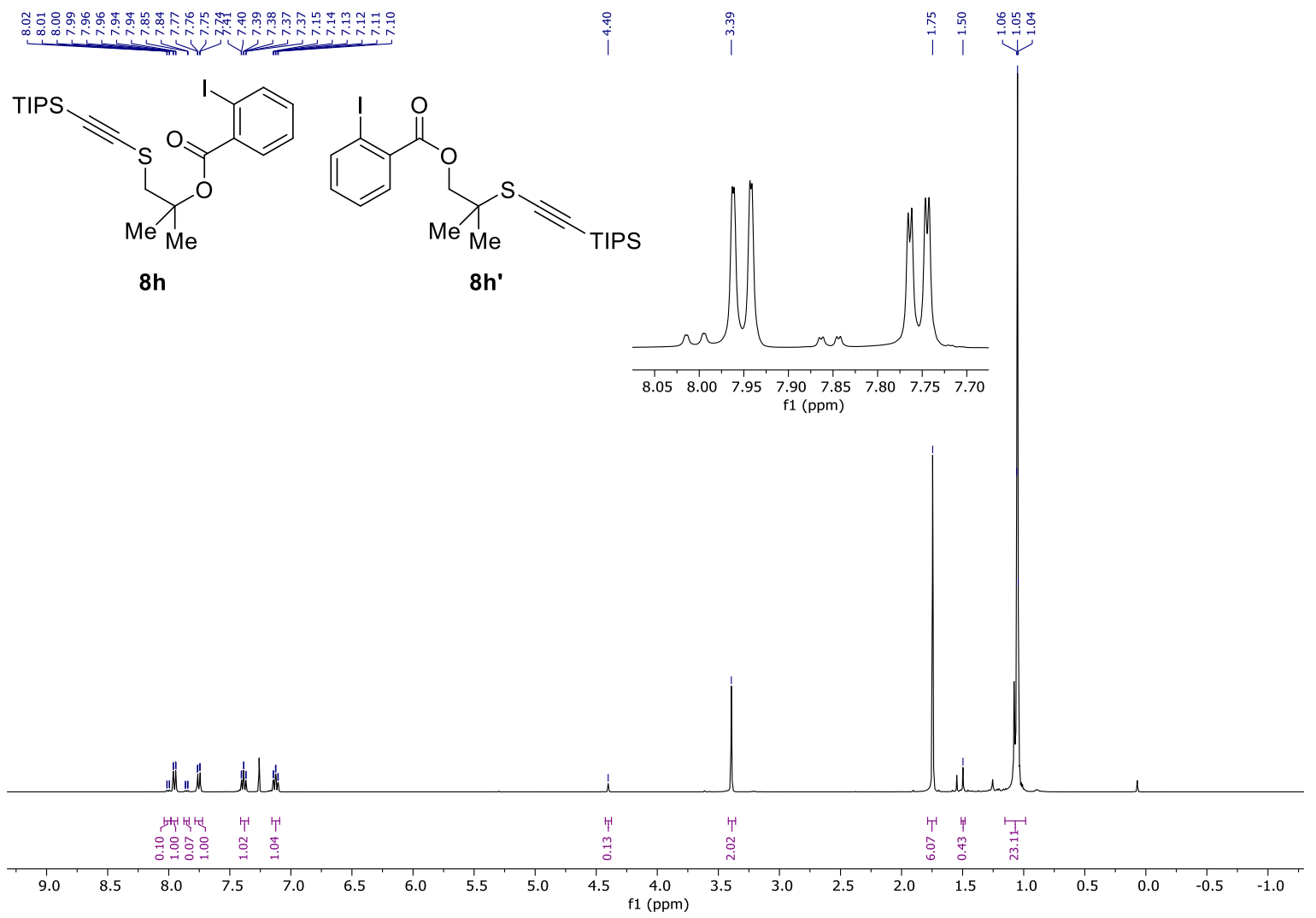

${ }^{13} \mathrm{C}$ NMR (100 MHz, $\mathrm{CDCl}_{3}$ ) of compound $\mathbf{8 h}$ and $\mathbf{8 h}$ ':

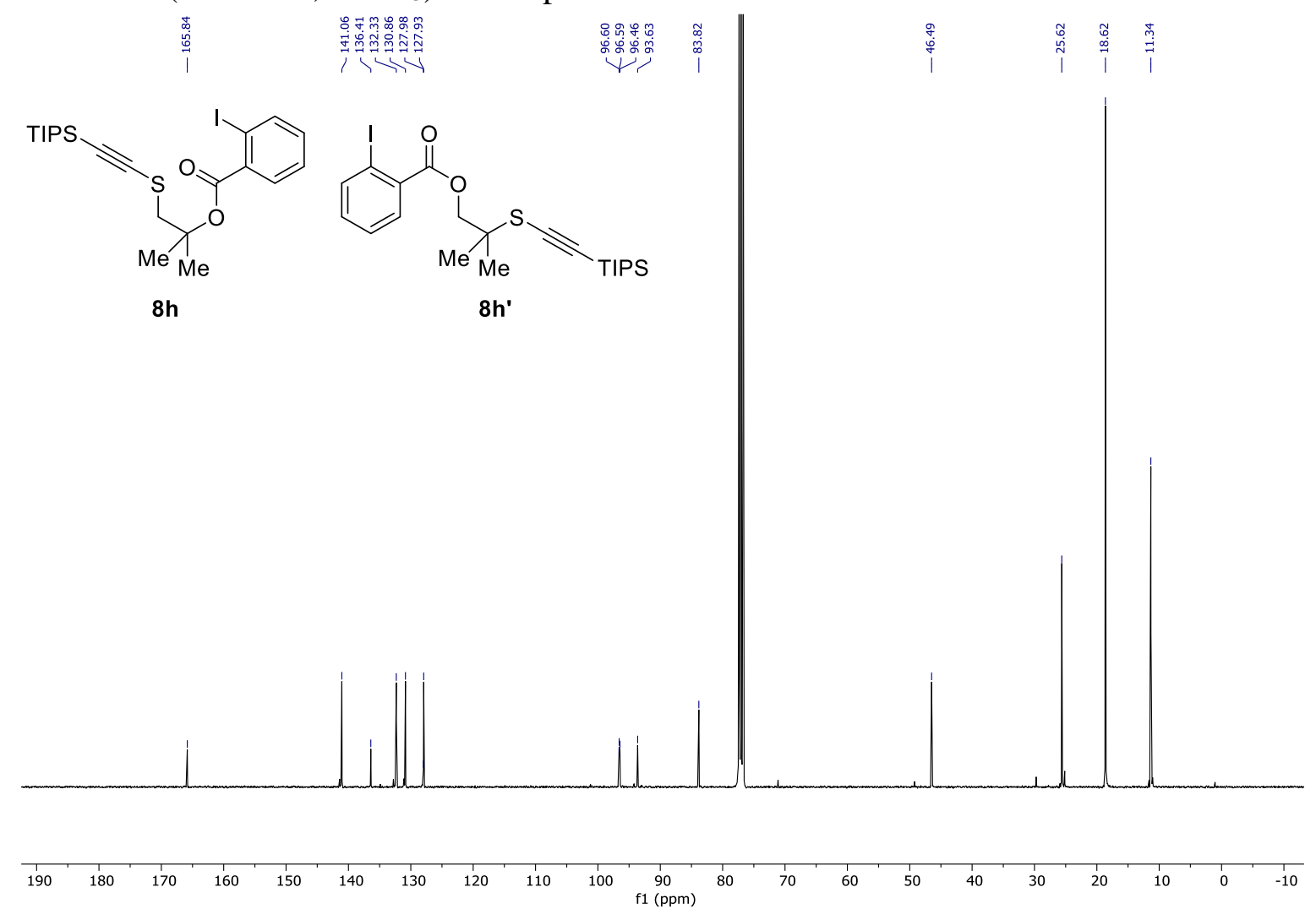


${ }^{1} \mathrm{H}$ NMR (400 MHz, $\mathrm{CDCl}_{3}$ ) of compound $\mathbf{8 i}$ :

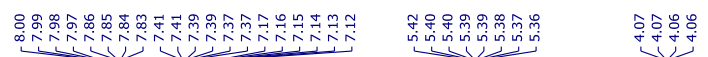

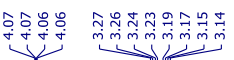

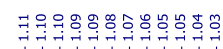<smiles>O=C(O)c1ccccc1I</smiles>

TIPSO \...'
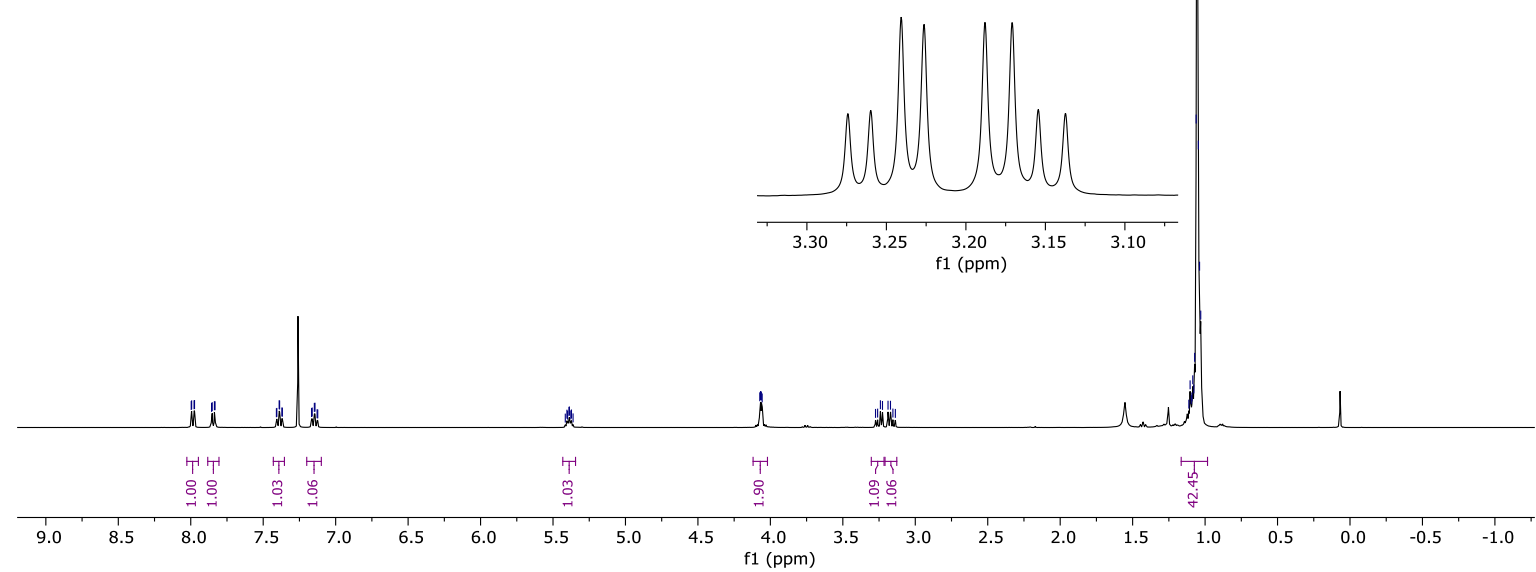

${ }^{13} \mathrm{C}$ NMR (100 MHz, $\mathrm{CDCl}_{3}$ ) of compound 8i:

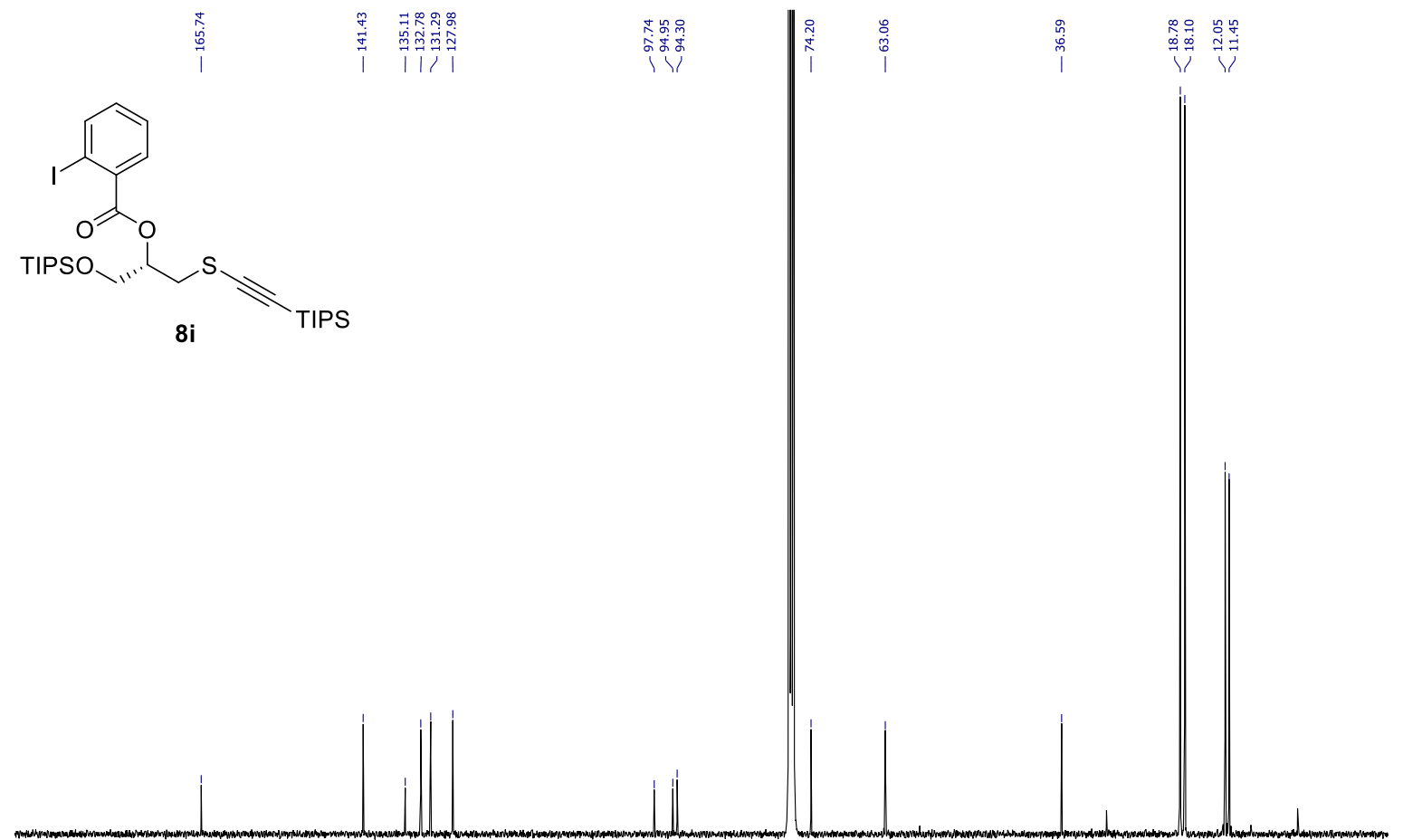

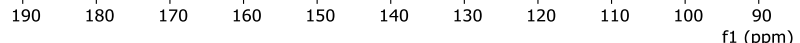


HPLC of compound 8i:

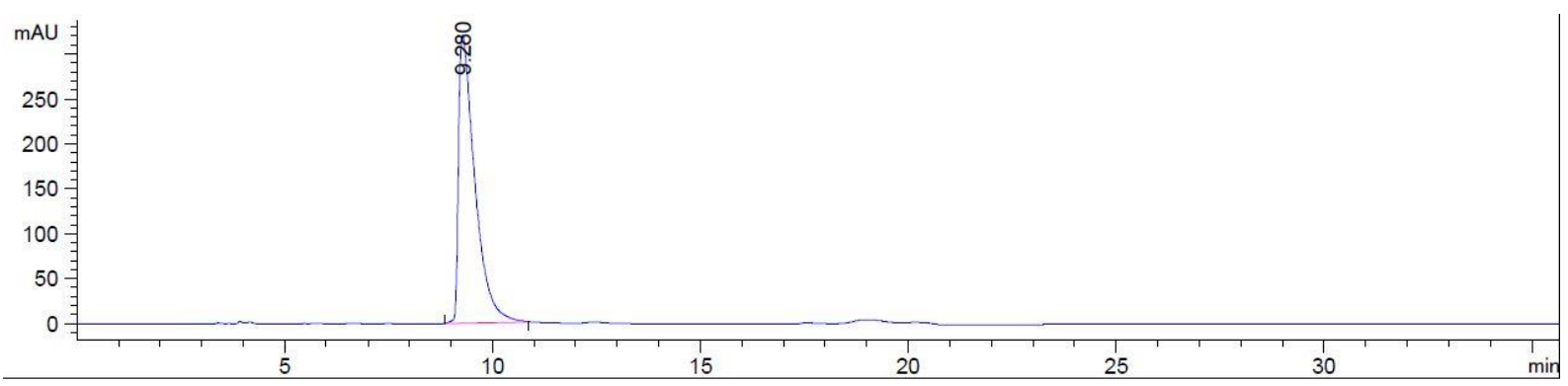

Signal 4: DAD1 D, Sig $=230,4$ Ref $=360,100$

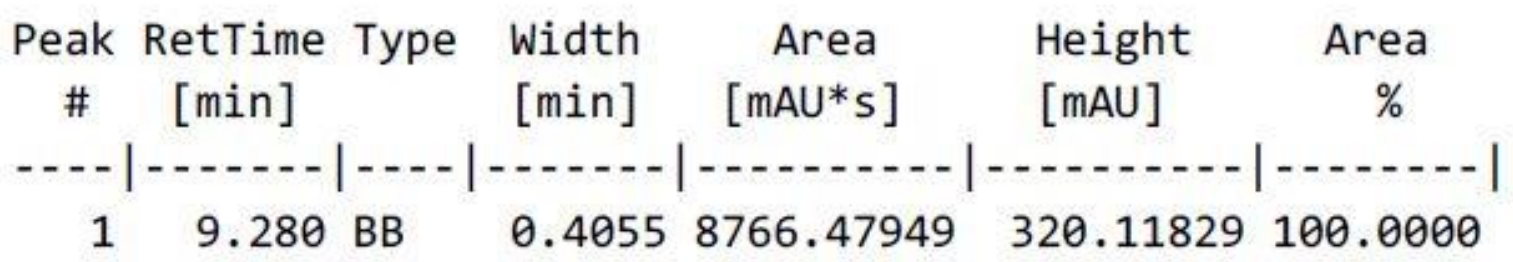

HPLC of racemic $\mathbf{8 i}$ :

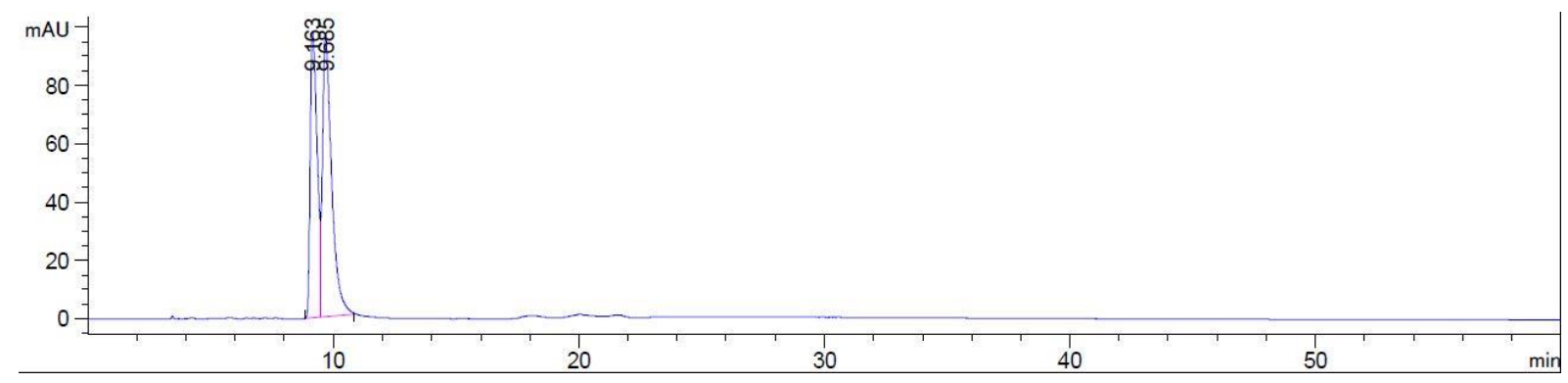

Signal 4: DAD1 D, Sig=230,4 Ref $=360,100$

Peak RetTime Type Width Area Height Area

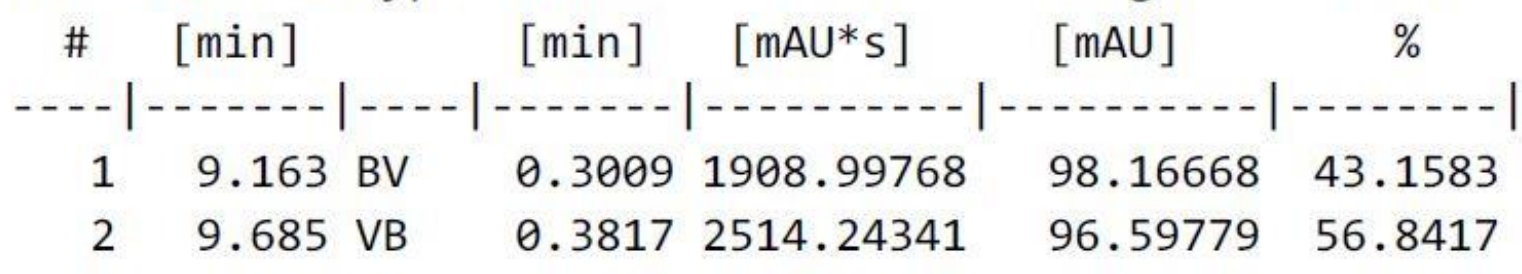

Totals :

$4423.24109 \quad 194.76447$ 
${ }^{1} \mathrm{H}$ NMR (400 MHz, $\mathrm{CDCl}_{3}$ ) of compound 8i':

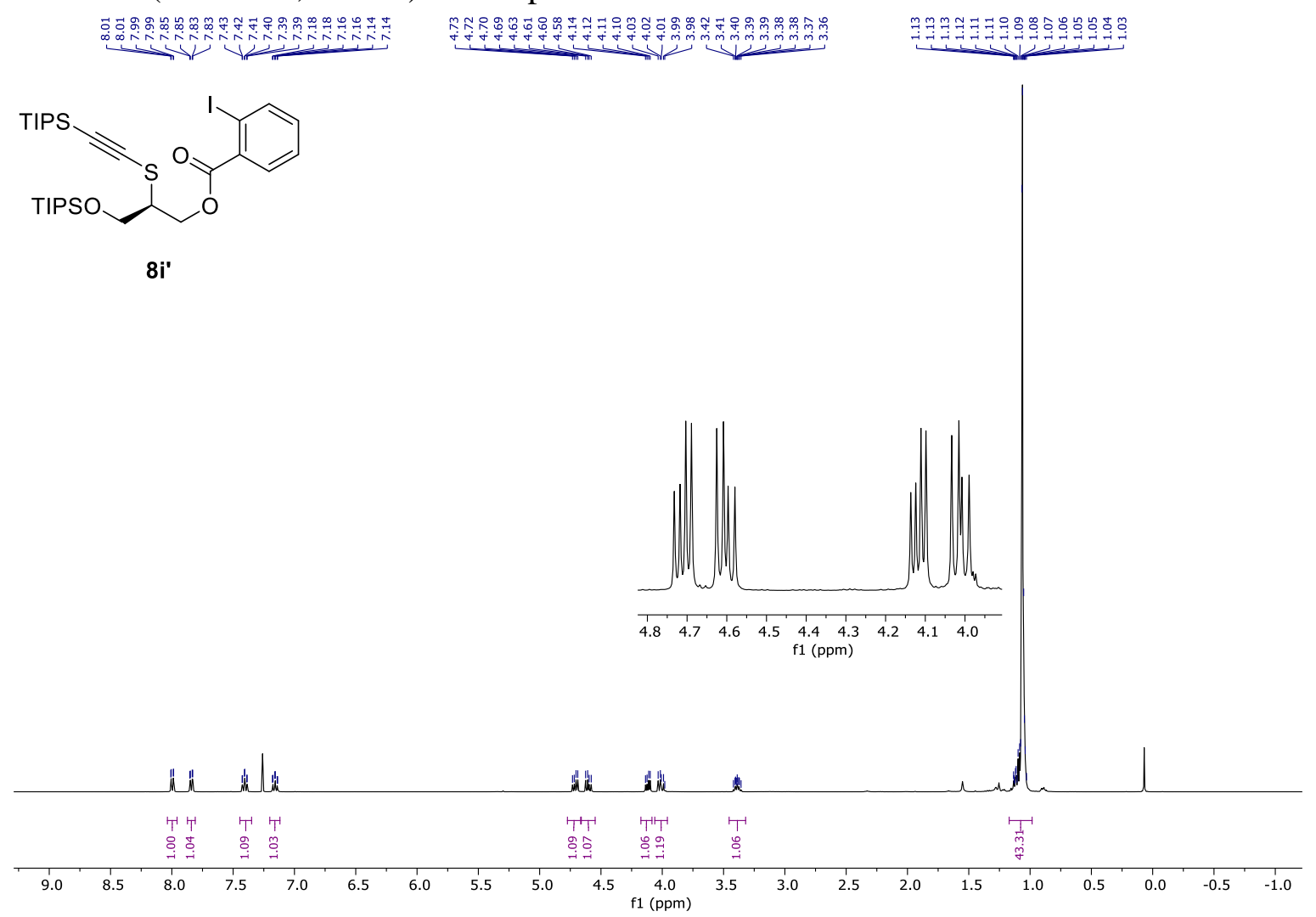

${ }^{13} \mathrm{C}$ NMR (100 MHz, $\mathrm{CDCl}_{3}$ ) of compound $\mathbf{8 i}$ ':

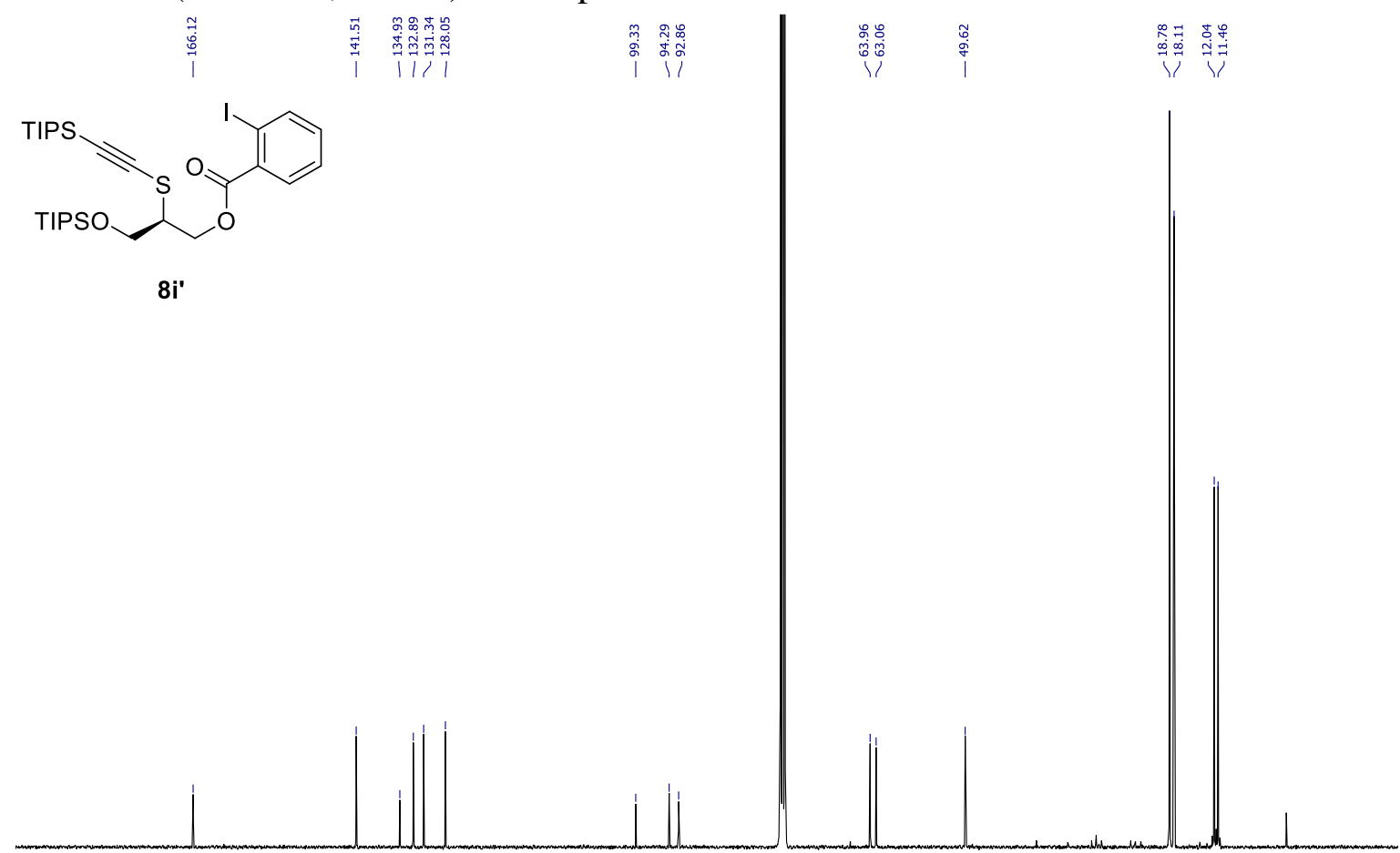

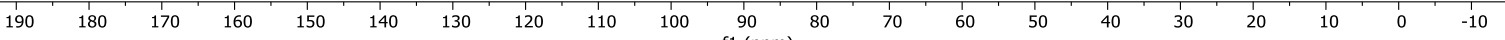


HPLC of compound 8i':

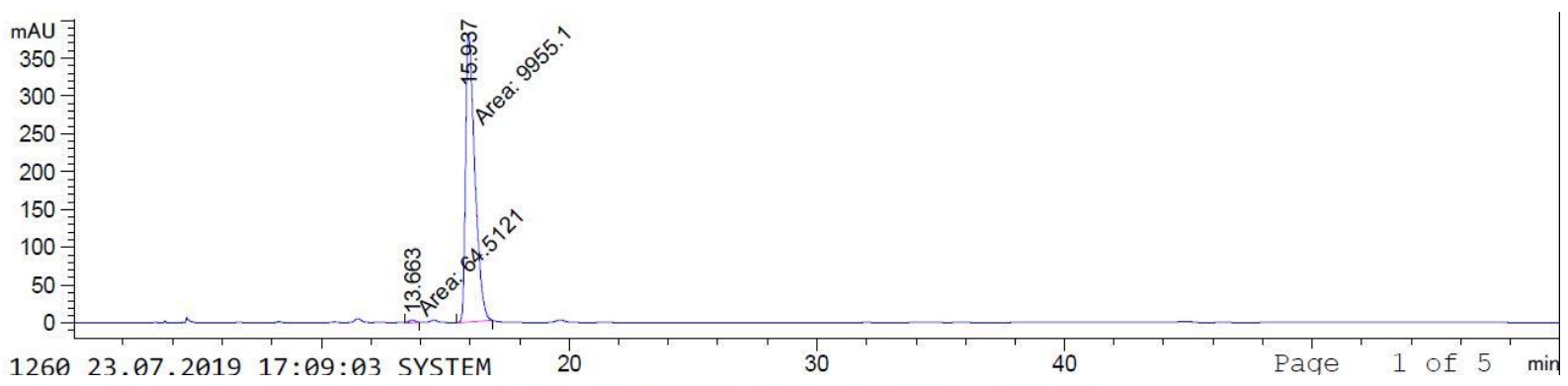

Signal 4: DAD1 D, Sig=230,4 $\operatorname{Re} f=360,100$

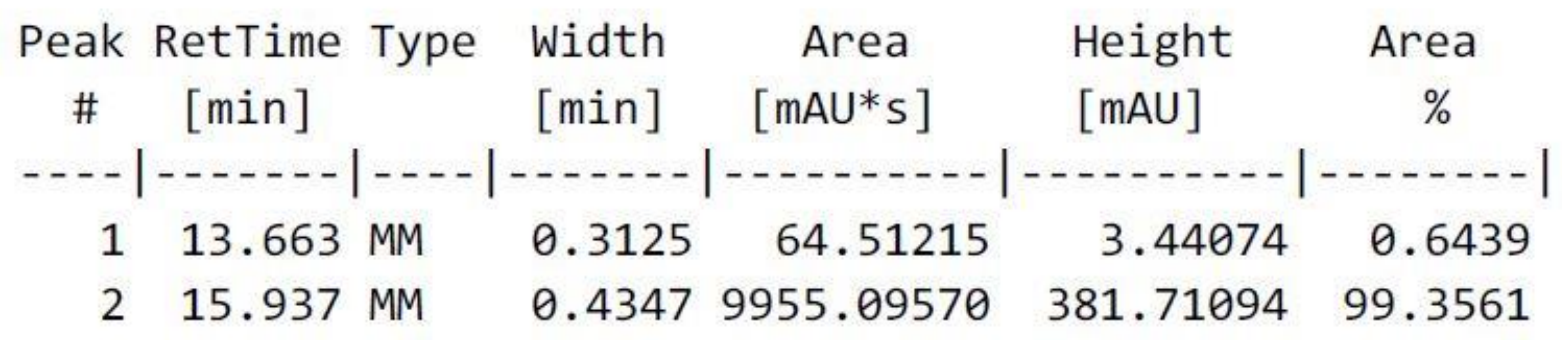
Totals :
$1.00196 \mathrm{e} 4 \quad 385.15168$

HPLC of racemic 8i':

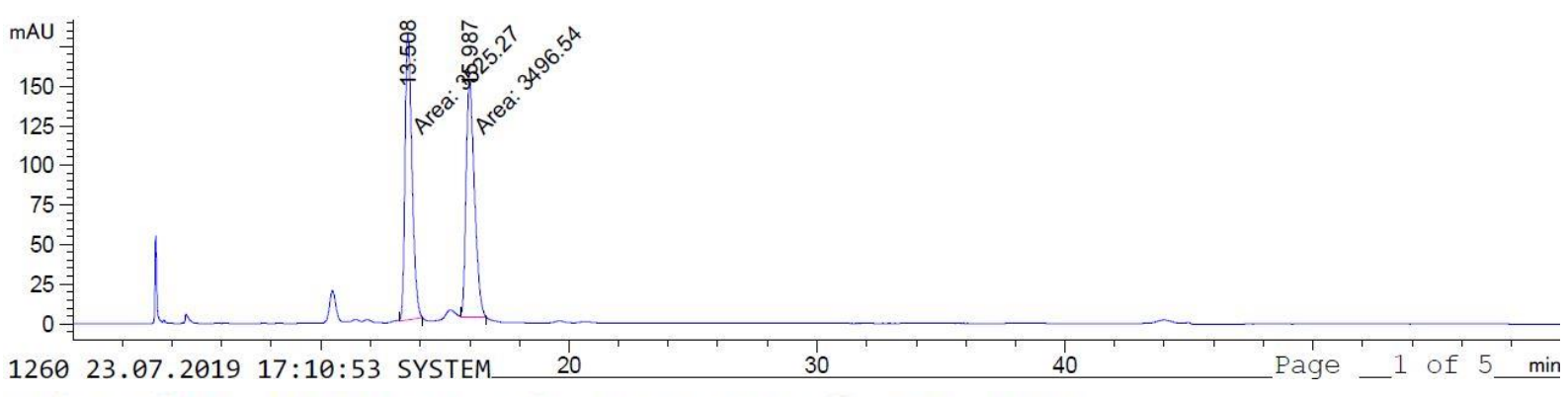

Signal 4: DAD1 D, Sig=230,4 Ref $=360,100$

\begin{tabular}{|c|c|c|c|c|}
\hline eak & $\begin{array}{l}\text { RetTime Type } \\
\text { [min] }\end{array}$ & $\begin{array}{l}\text { Width } \\
\text { [min] }\end{array}$ & $\begin{array}{c}\text { Area } \\
{\left[\mathrm{mAU}^{*} \mathrm{~s}\right]}\end{array}$ & $\begin{array}{l}\text { Height } \\
{[\mathrm{mAU}]}\end{array}$ \\
\hline
\end{tabular}

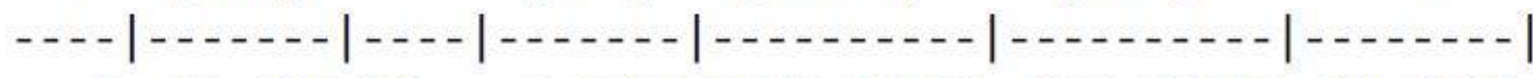

$\begin{array}{lllllll}1 & 13.508 & \text { MM } & 0.3254 & 3525.26782 & 180.54846 & 50.2045\end{array}$

$\begin{array}{llllll}2 & 15.987 \text { MM } & 0.3925 & 3496.54175 & 148.46820 & 49.7955\end{array}$

Totals :

$7021.80957 \quad 329.01666$ 
${ }^{1} \mathrm{H}$ NMR (400 MHz, $\mathrm{CDCl}_{3}$ ) of compound $\mathbf{8 j}$ :

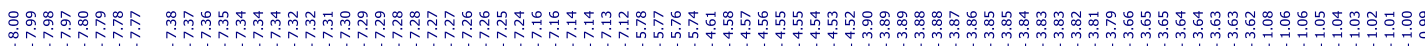<smiles>CC(C)SC#CSC(COCc1ccccc1)[C@H](COCc1ccccc1)OC(=O)c1ccccc1I</smiles>

8j

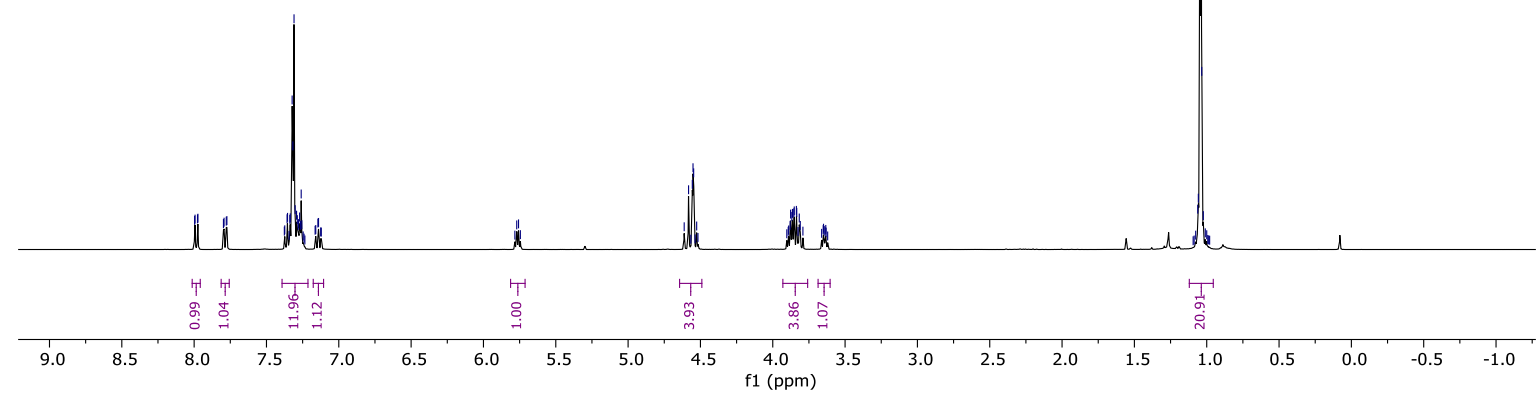

${ }^{13} \mathrm{C}$ NMR (100 MHz, $\mathrm{CDCl}_{3}$ ) of compound $\mathbf{8 j}$ :

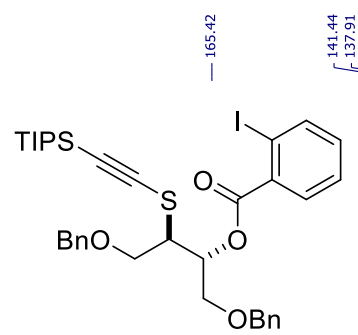

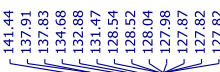

锤器

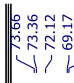

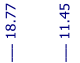

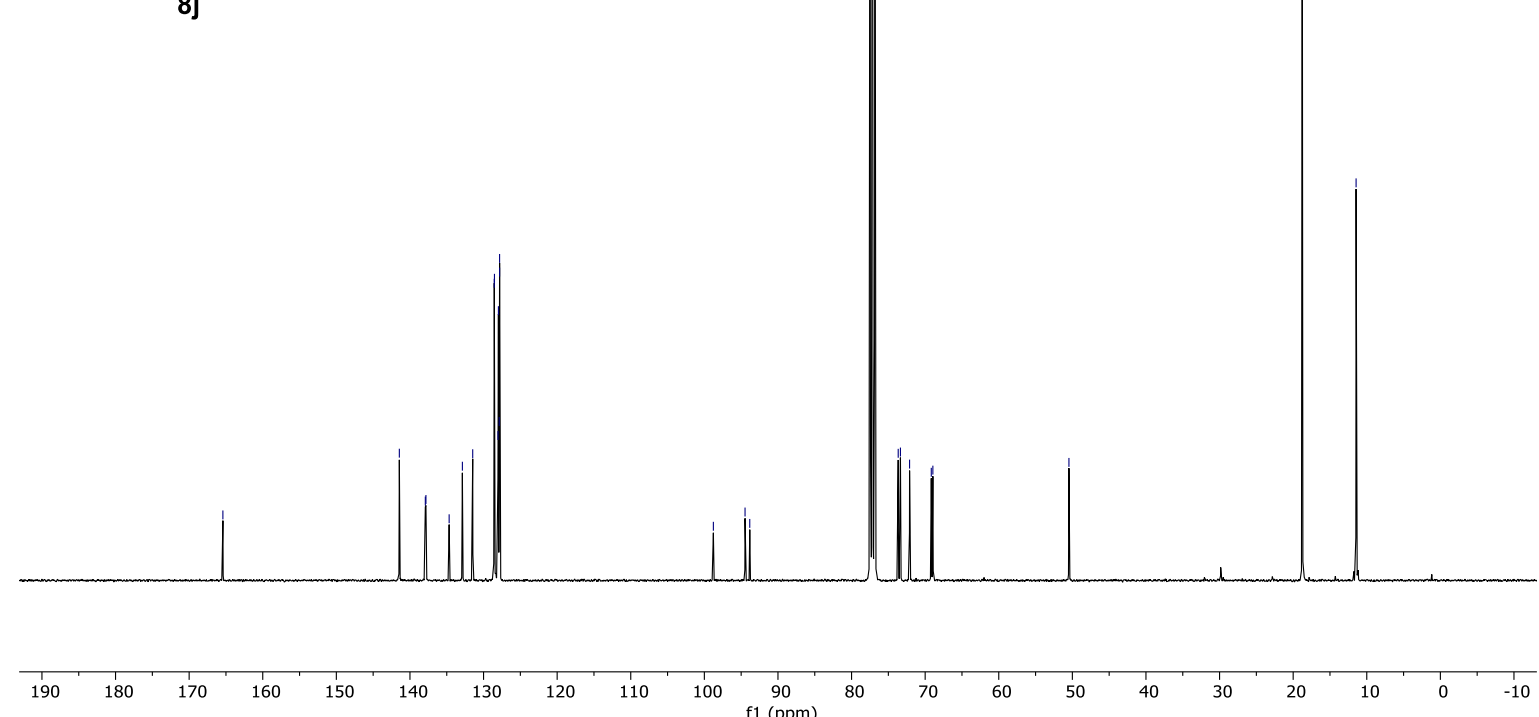


${ }^{1} \mathrm{H}$ NMR $\left(400 \mathrm{MHz}, \mathrm{CDCl}_{3}\right)$ of compound $\mathbf{8 k}$ :

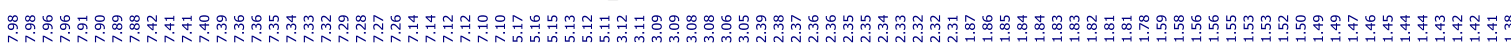

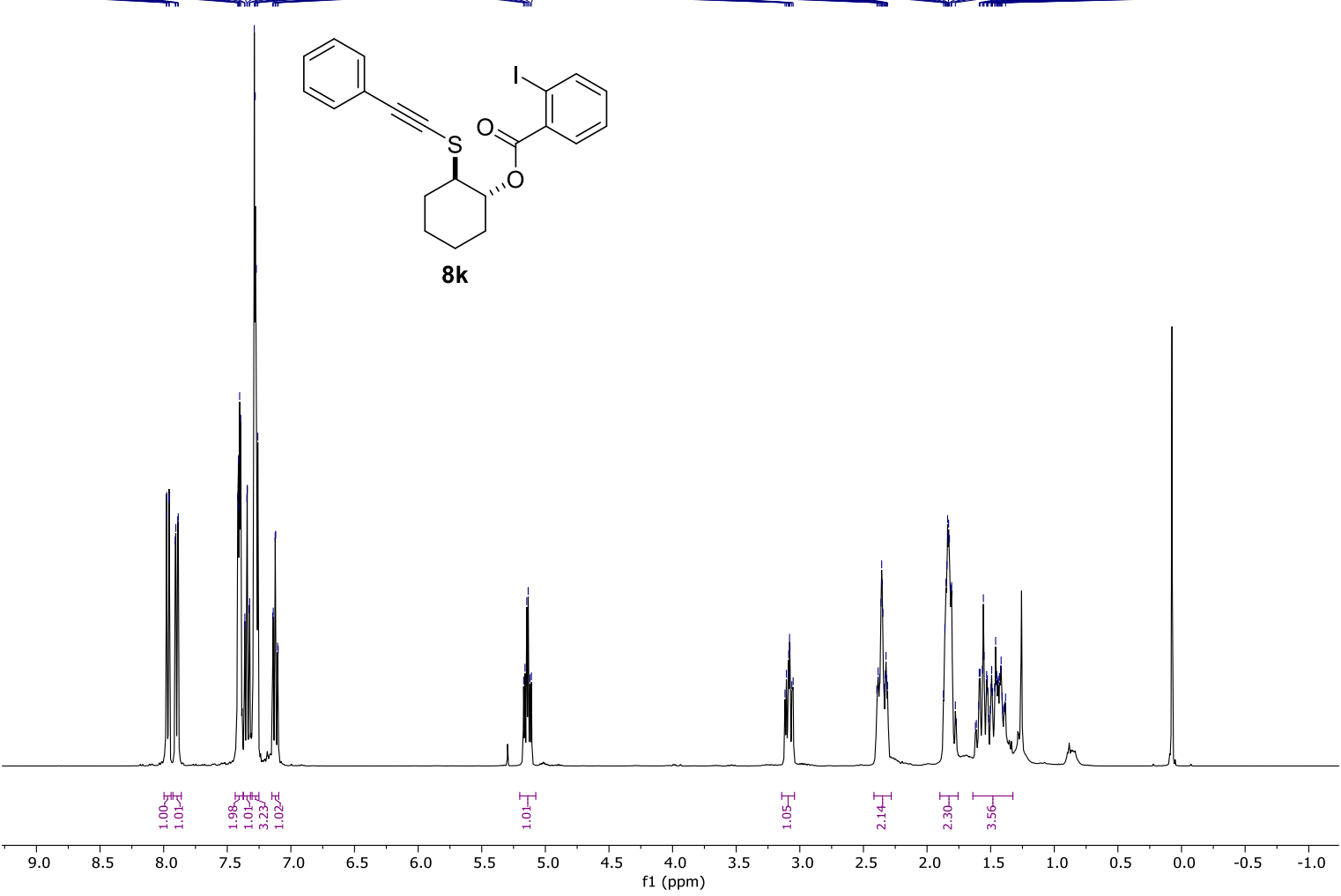

${ }^{13} \mathrm{C}$ NMR $\left(100 \mathrm{MHz}, \mathrm{CDCl}_{3}\right)$ of compound 8k:

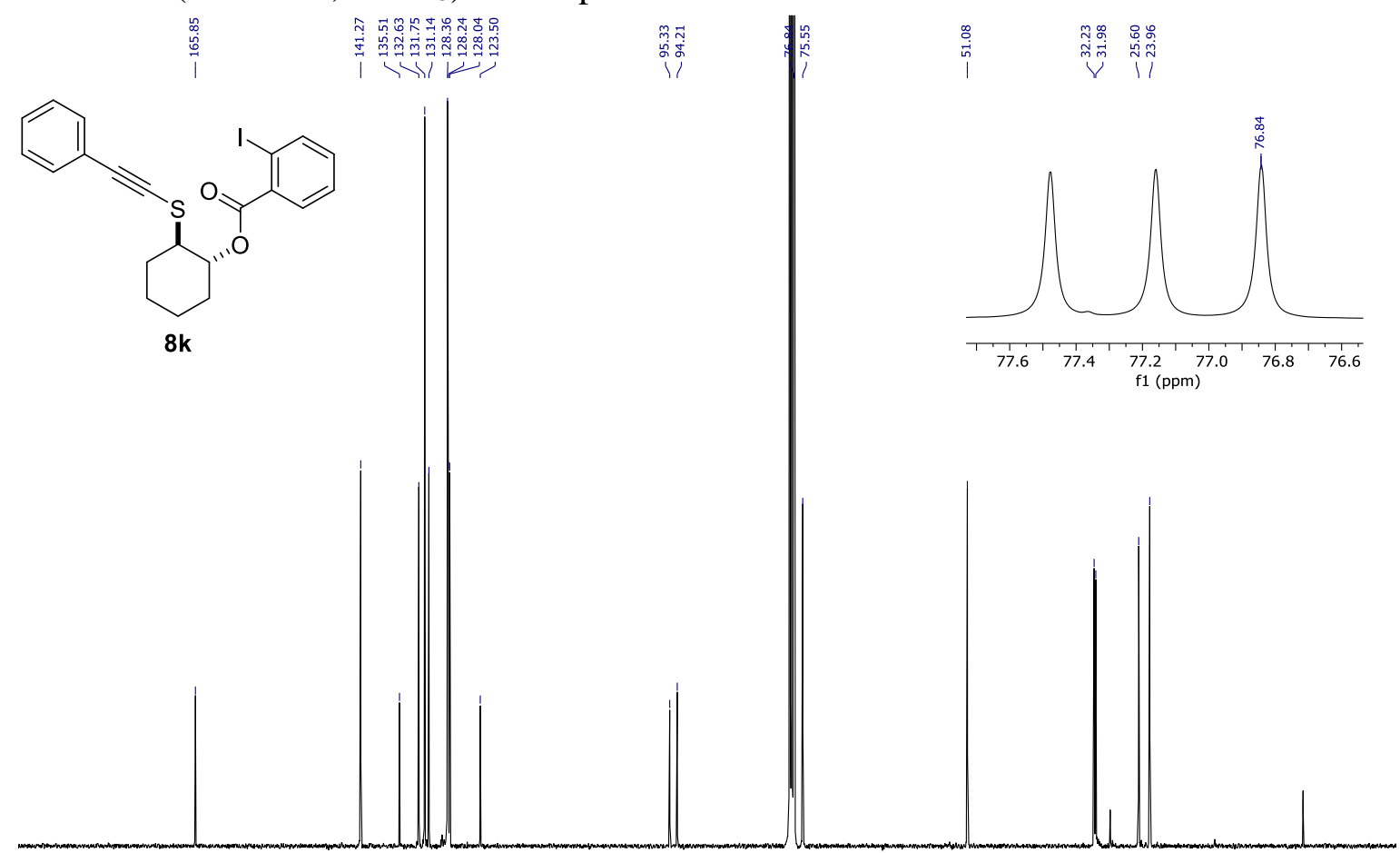

$\begin{array}{llllllllllllllllllll}190 & 180 & 170 & 160 & 150 & 140 & 130 & 120 & 110 & 100 & 90 & 80 & 70 & 60 & 50 & 40 & 30 & 20 & 10 & 0\end{array}$ 
${ }^{1} \mathrm{H}$ NMR (400 MHz, $\mathrm{CDCl}_{3}$ ) of compound 8I:

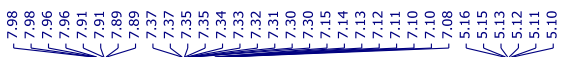

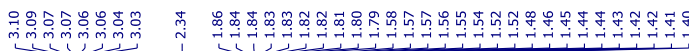<smiles>Cc1ccc(C#CC2CCCCC2OC(=O)c2ccccc2I)cc1</smiles>

81

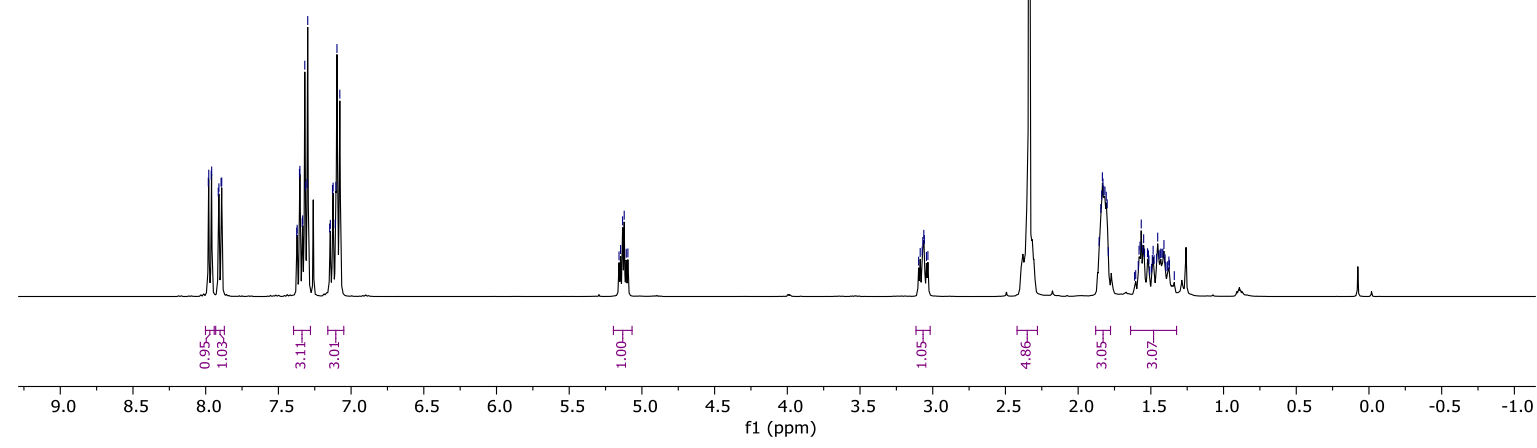

${ }^{13} \mathrm{C}$ NMR (100 MHz, $\mathrm{CDCl}_{3}$ ) of compound 8I:

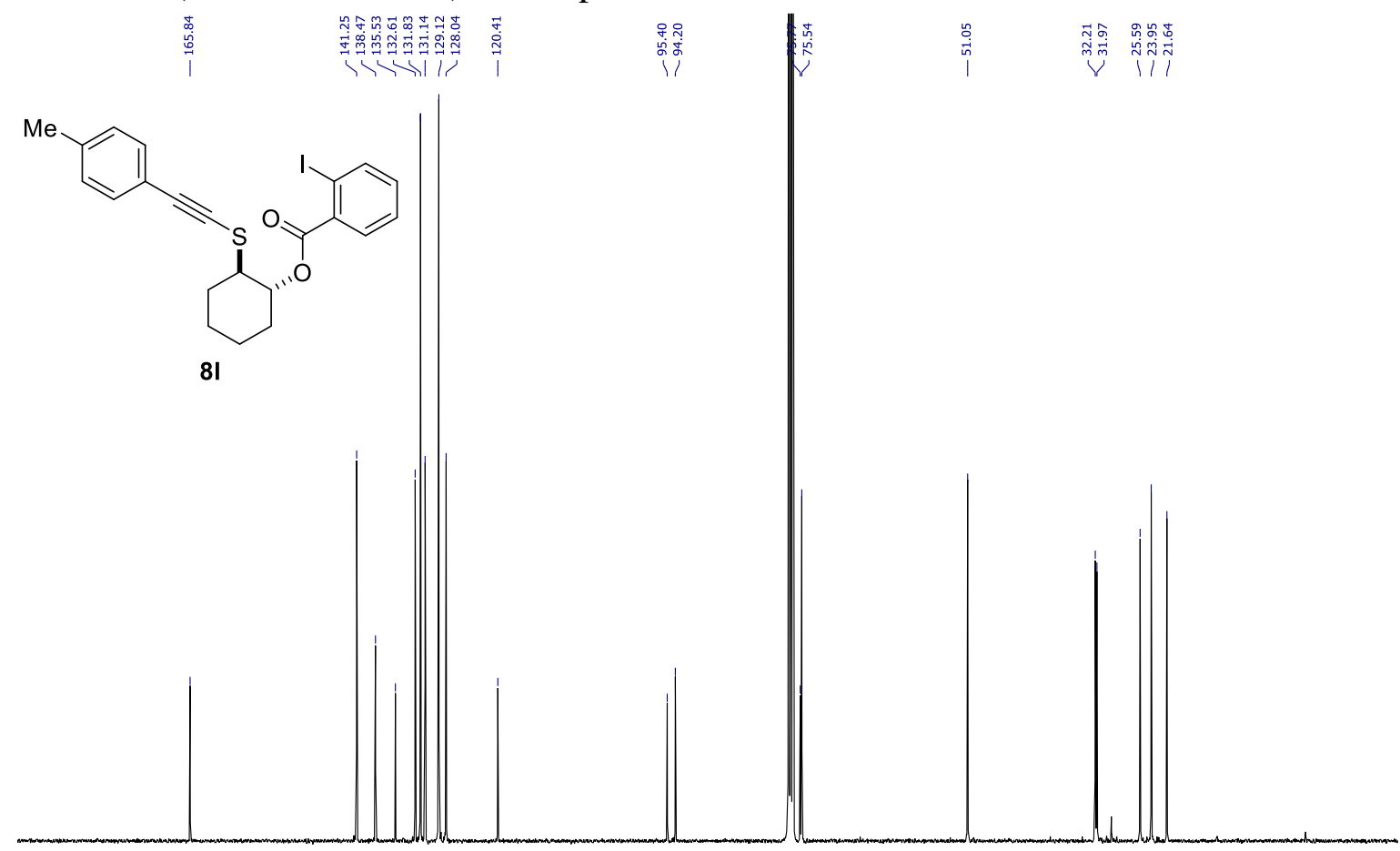


${ }^{1} \mathrm{H}$ NMR (400 MHz, $\mathrm{CDCl}_{3}$ ) of compound $\mathbf{8 m}$ :

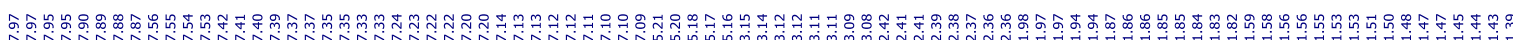

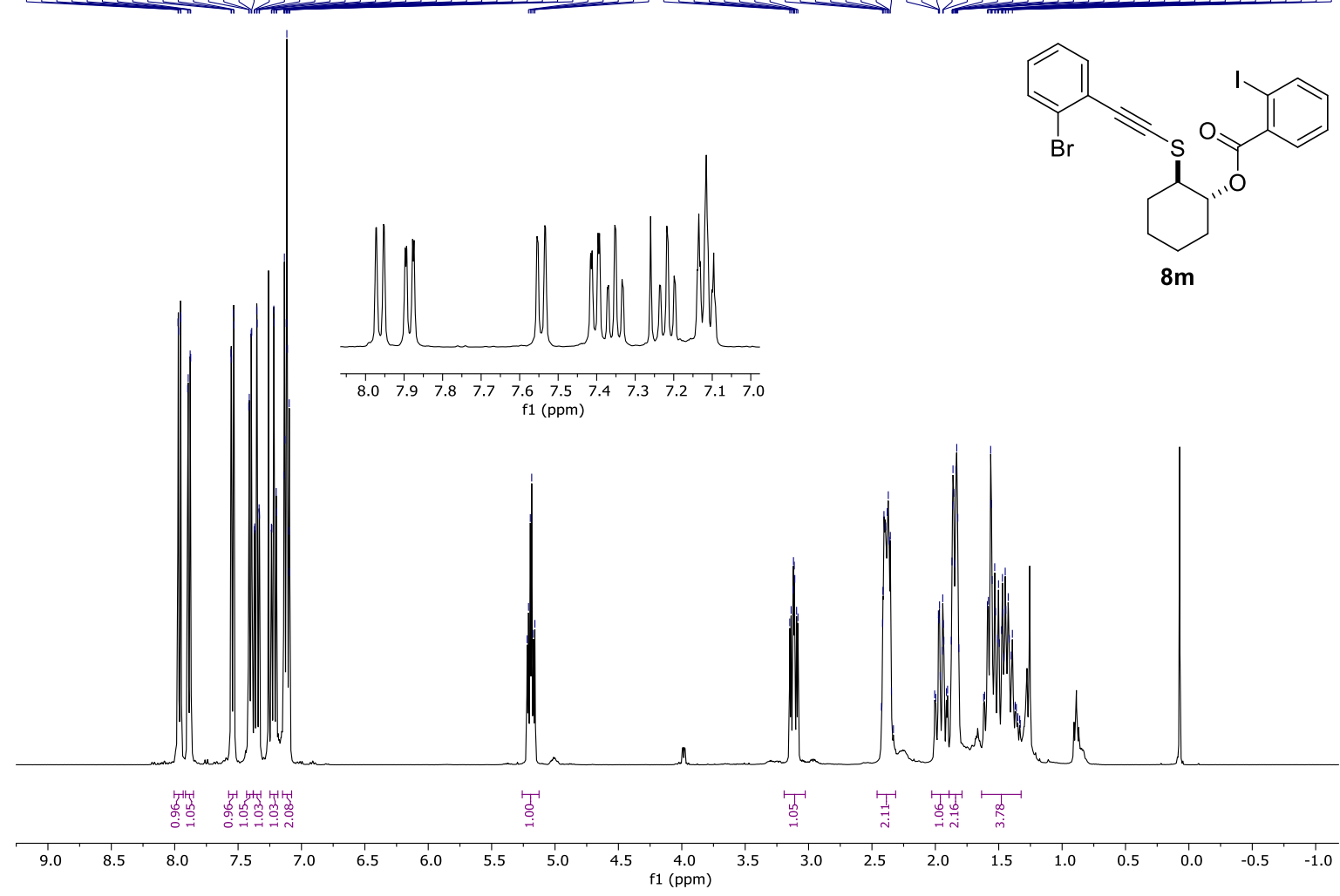

${ }^{13} \mathrm{C}$ NMR $\left(100 \mathrm{MHz}, \mathrm{CDCl}_{3}\right)$ of compound $\mathbf{8 m}$ :
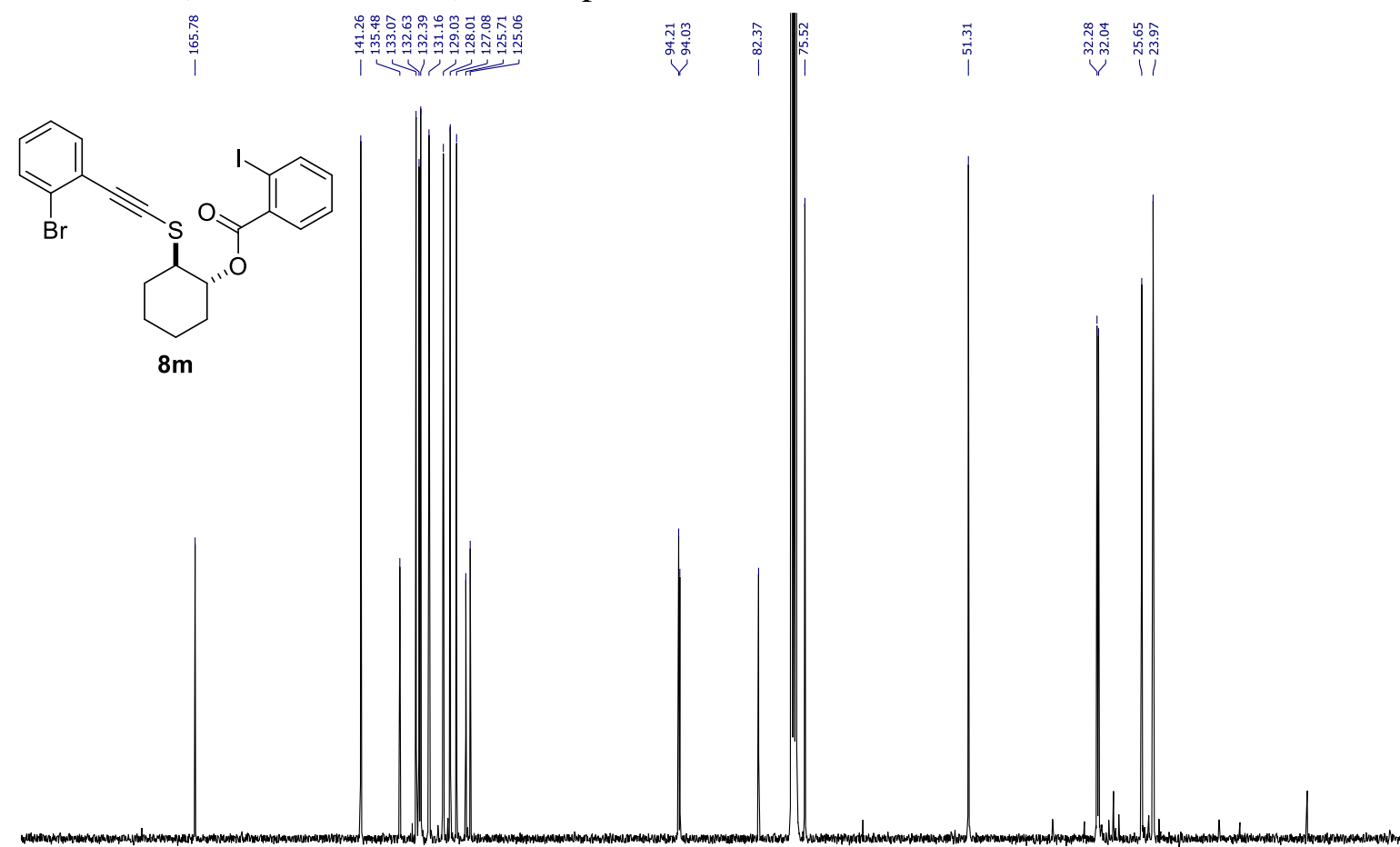
${ }^{1} \mathrm{H}$ NMR (400 MHz, $\mathrm{CDCl}_{3}$ ) of compound $\mathbf{8 n}$ :

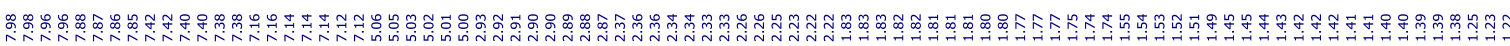<smiles>CC(C)(C)C#CSC1CCCCC1OC(=O)c1ccccc1I</smiles>

$8 n$

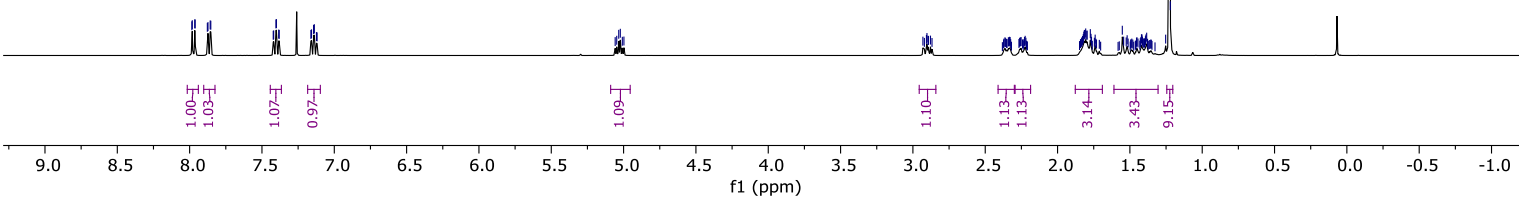

${ }^{13} \mathrm{C}$ NMR $\left(100 \mathrm{MHz}, \mathrm{CDCl}_{3}\right)$ of compound $\mathbf{8 n}$ :

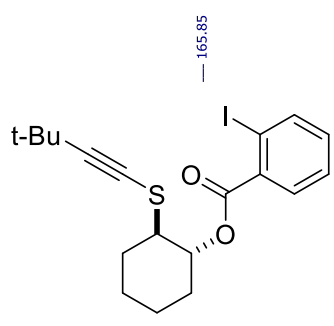

$8 n$
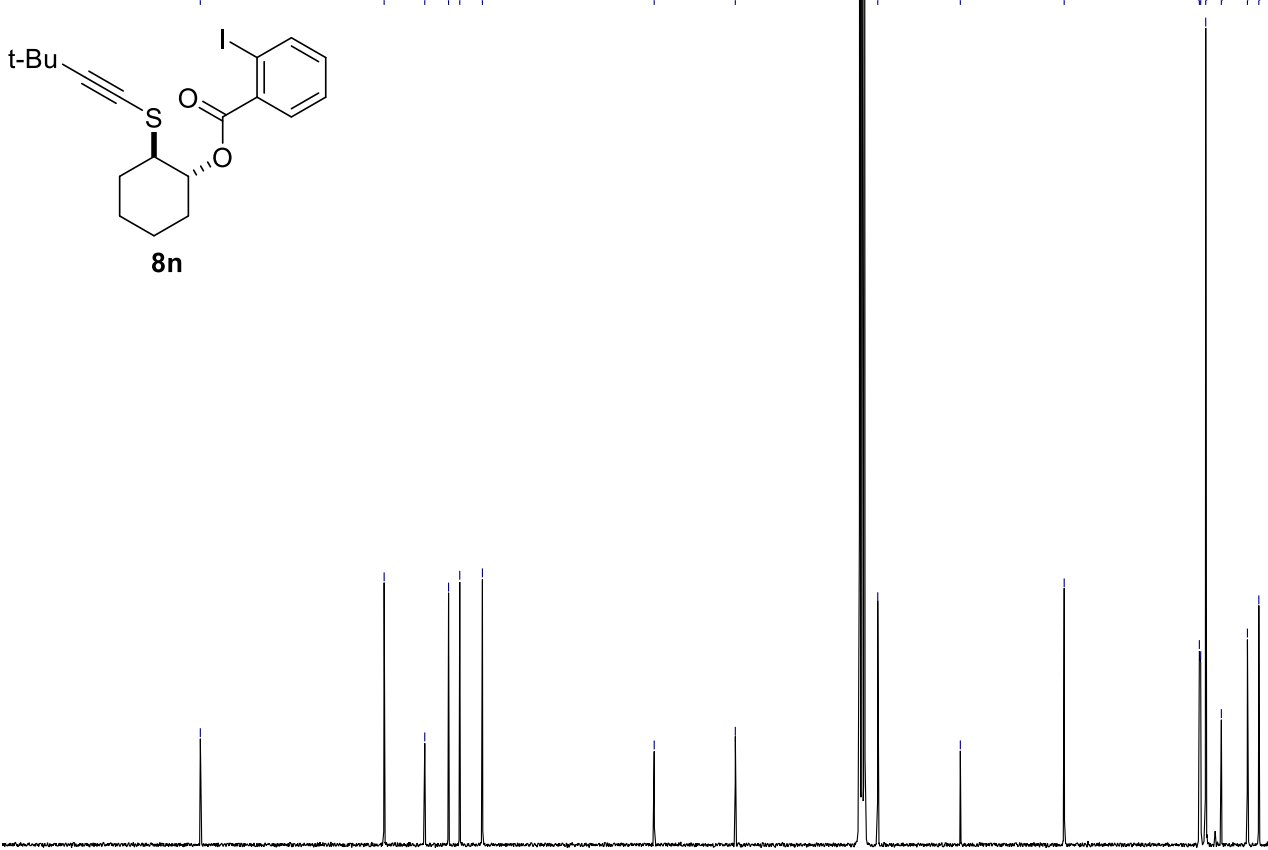
${ }^{1} \mathrm{H}$ NMR (400 MHz, $\mathrm{CDCl}_{3}$ ) of compound 8o:

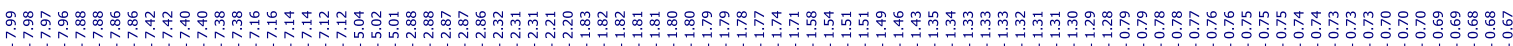<smiles>O=C(OC1CCCCC1)c1ccccc1I</smiles>

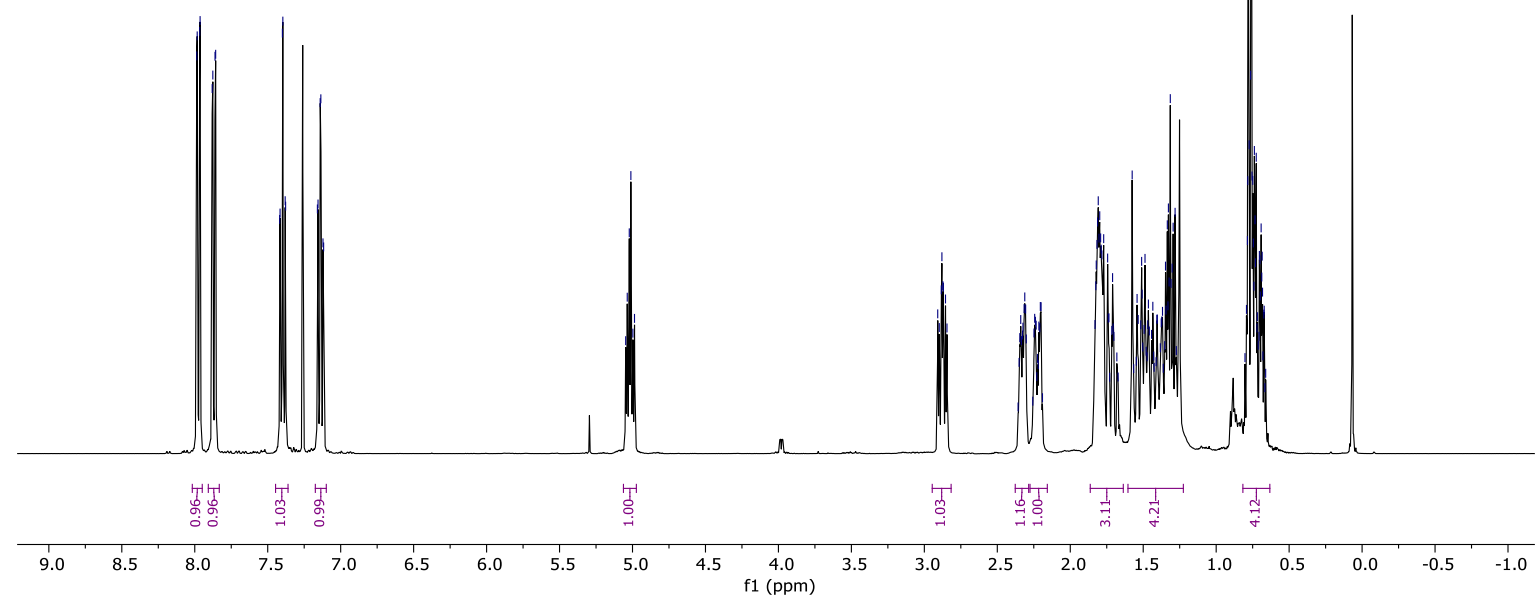

${ }^{13} \mathrm{C}$ NMR $\left(100 \mathrm{MHz}, \mathrm{CDCl}_{3}\right)$ of compound $8 \mathbf{8}$ :

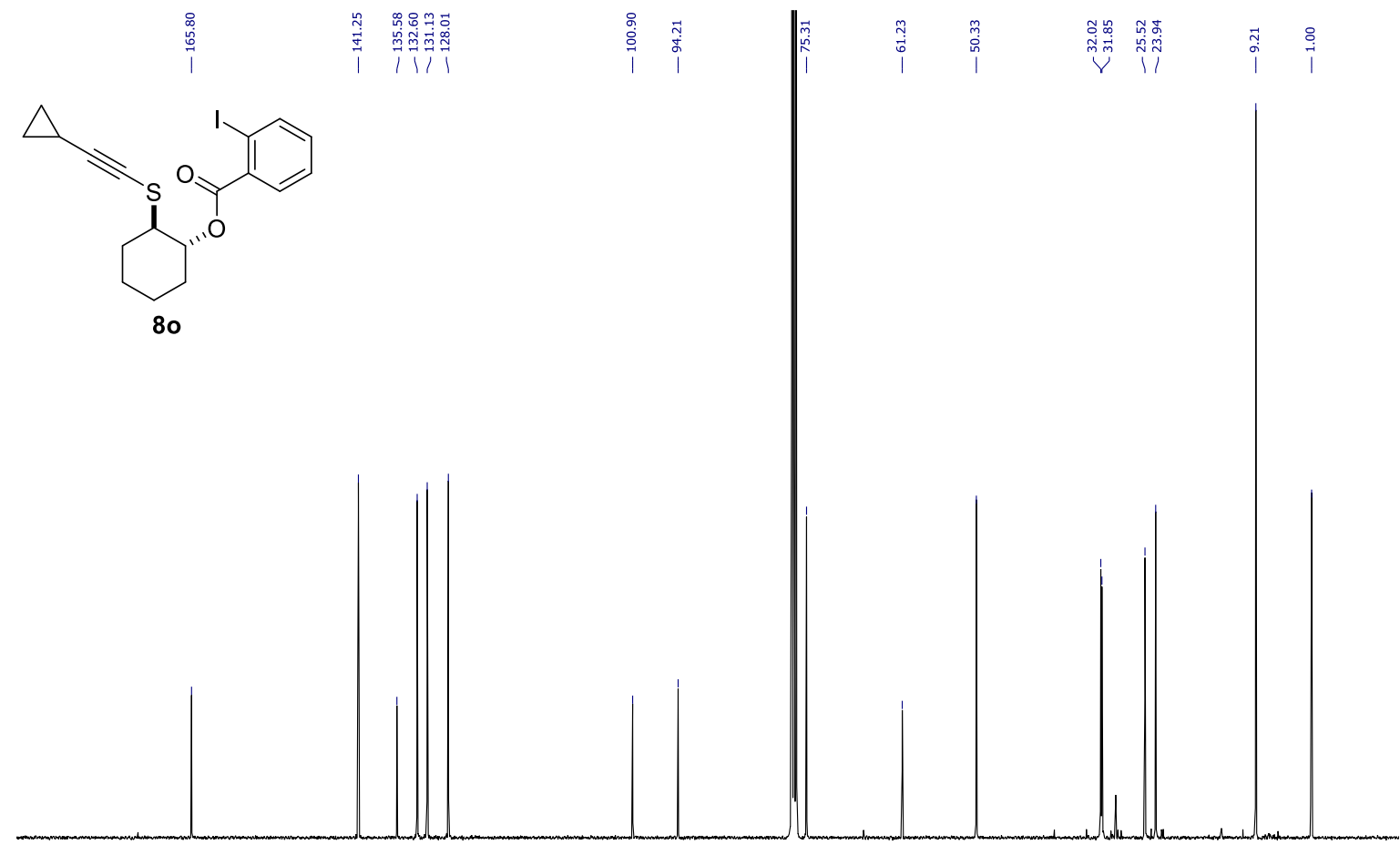

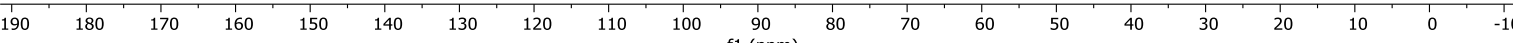


${ }^{1} \mathrm{H}$ NMR (400 MHz, $\mathrm{CDCl}_{3}$ ) of compound $\mathbf{8 p}$ :

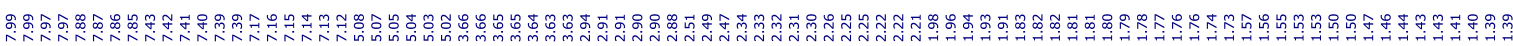<smiles>O=C(O[C@H]1CCCCC1SC#CCCCCl)c1ccccc1I</smiles>

$8 p$
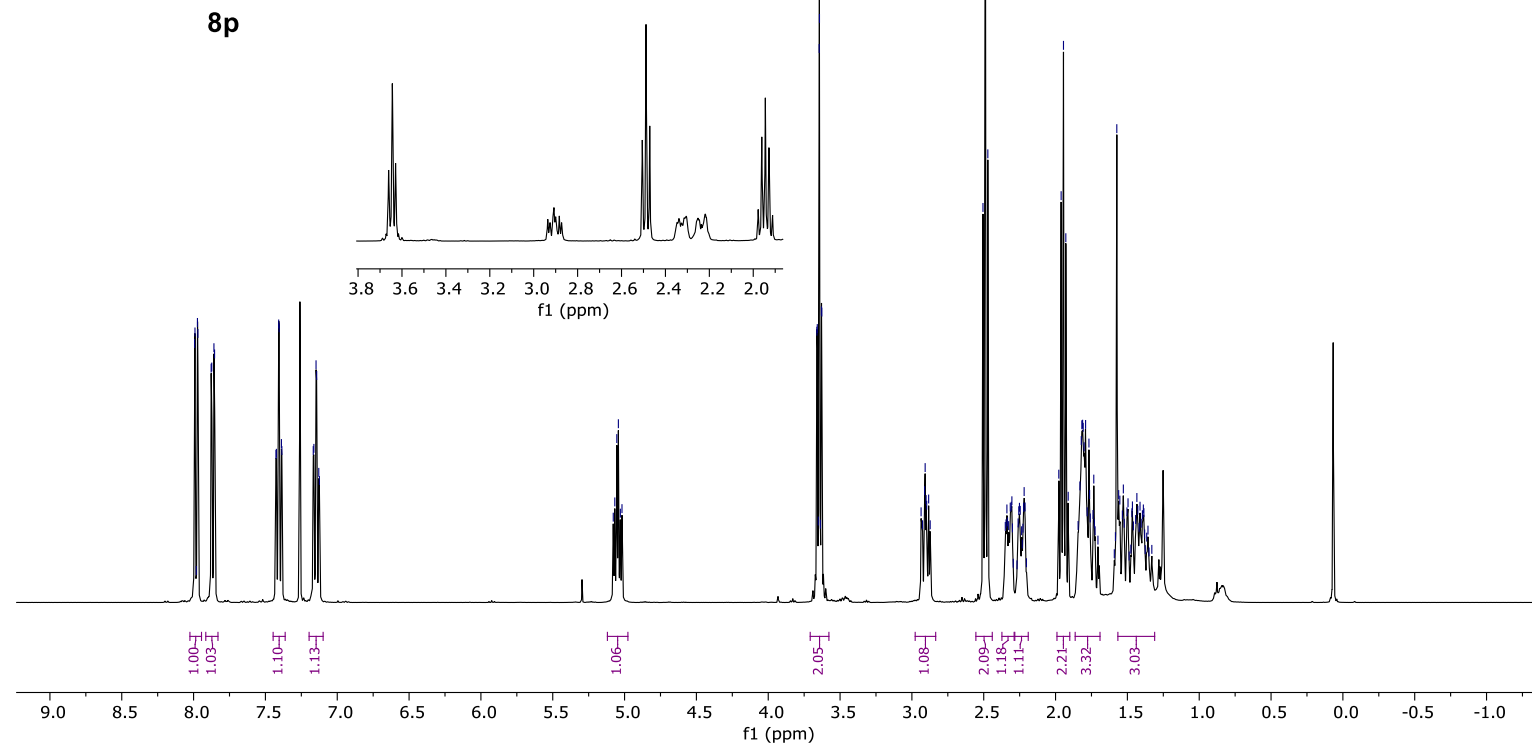

${ }^{13} \mathrm{C}$ NMR $\left(100 \mathrm{MHz}, \mathrm{CDCl}_{3}\right)$ of compound $\mathbf{8 p}$ :

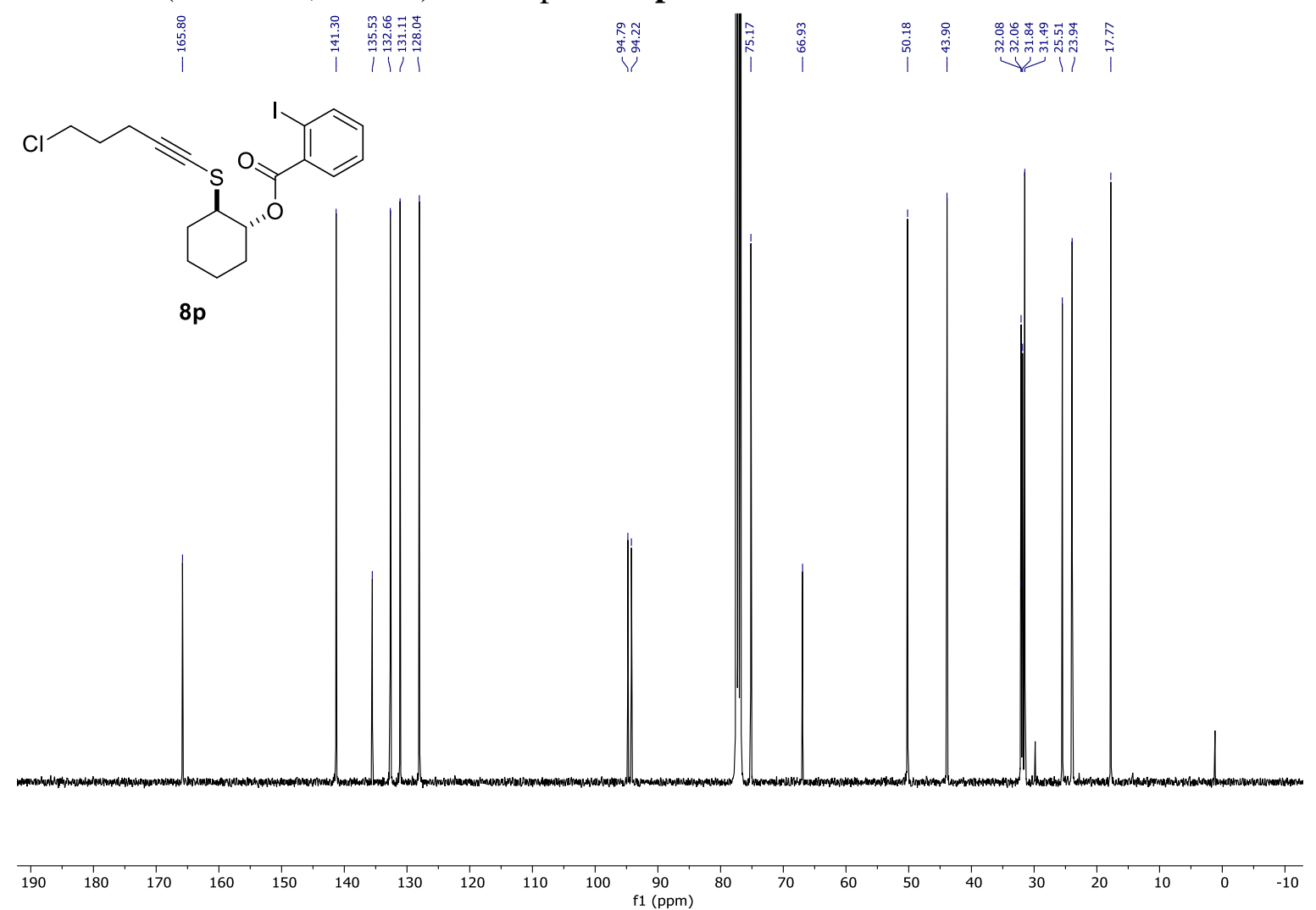


${ }^{1} \mathrm{H}$ NMR (400 MHz, $\left.\mathrm{CDCl}_{3}\right)$ of compound 8q:

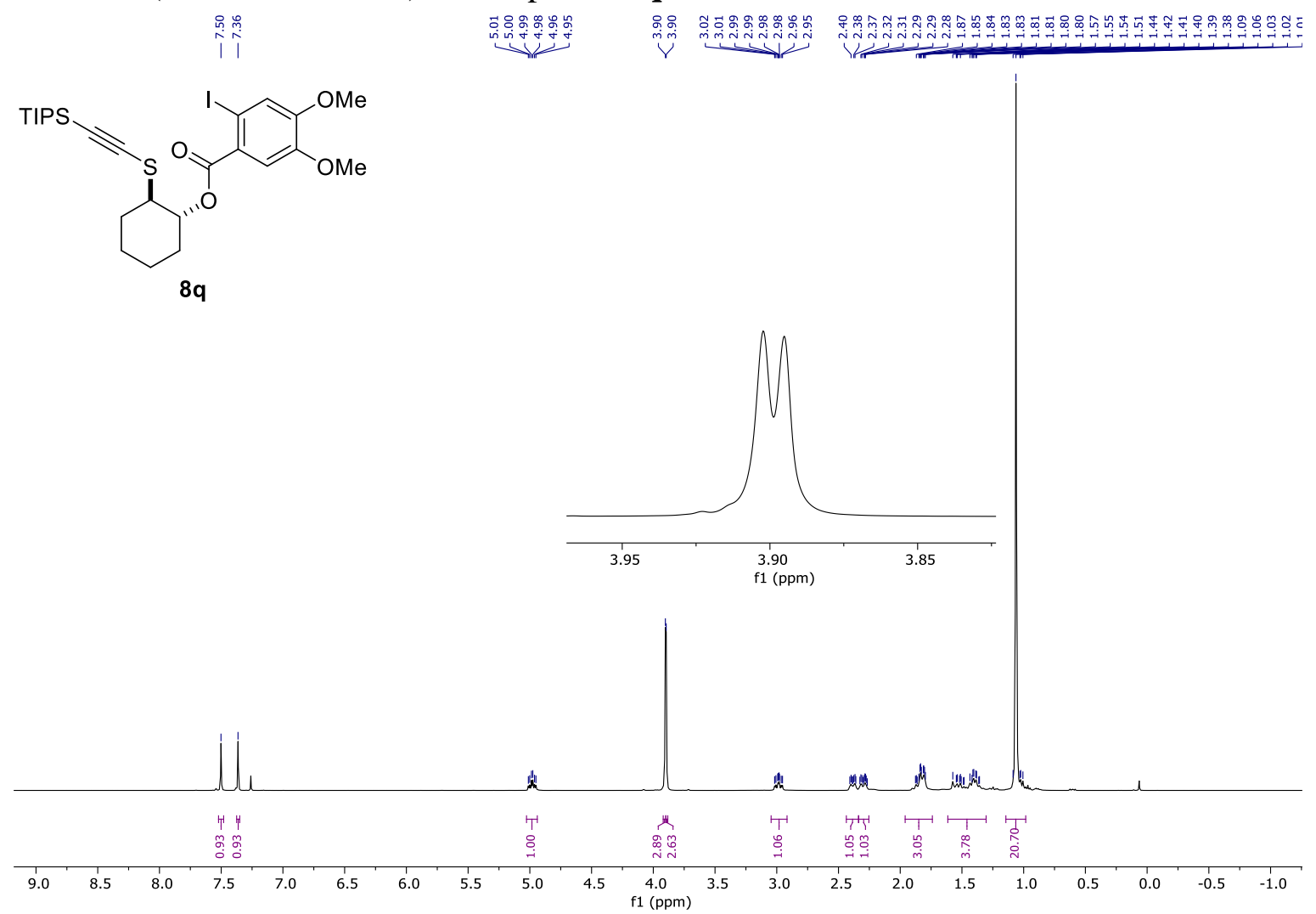

${ }^{13} \mathrm{C} \mathrm{NMR}\left(100 \mathrm{MHz}, \mathrm{CDCl}_{3}\right)$ of compound 8q:

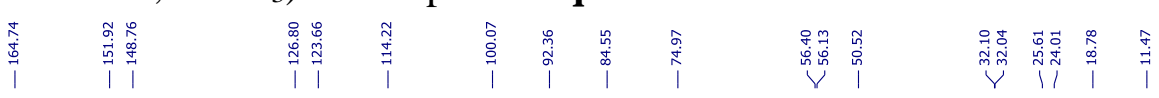<smiles>COc1cc(I)c(C(=O)O[C@H]2CCCCC2SC#CSC(C)C)cc1OC</smiles>

$8 q$

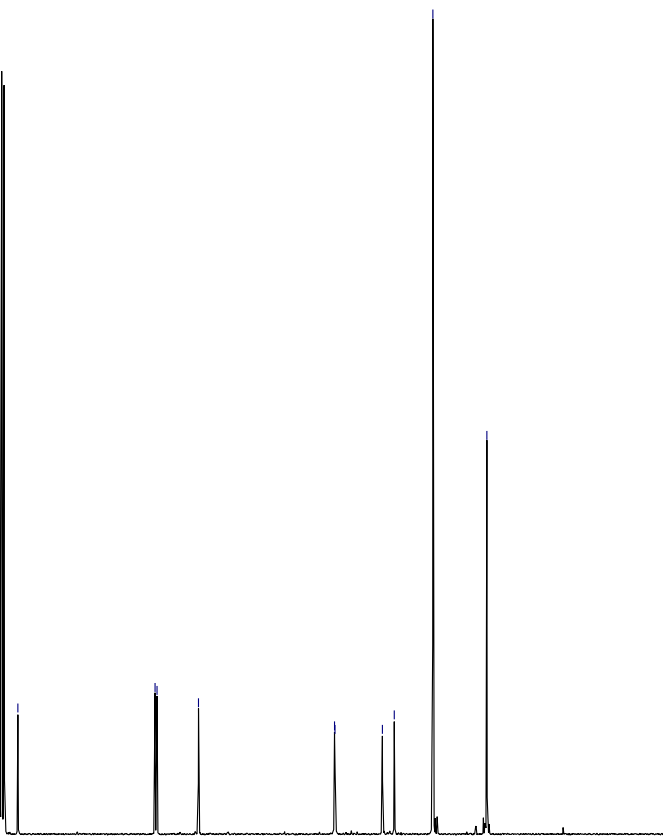

$\begin{array}{llllllllllllllllllllll}190 & 180 & 170 & 160 & 150 & 140 & 130 & 120 & 110 & 100 & 90 & 80 & 70 & 60 & 50 & 40 & 30 & 20 & 10 & 0 & -10\end{array}$ 
${ }^{1} \mathrm{H}$ NMR (400 MHz, $\mathrm{CDCl}_{3}$ ) of compound $\mathbf{8 r}$ :

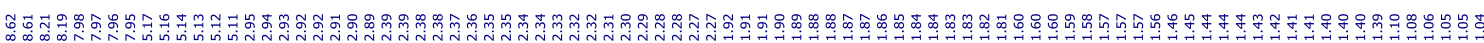<smiles>CC(C)SC#CS[C@H]1CCCC[C@@H]1OC(=O)c1cc([N+](=O)[O-])ccc1I</smiles>
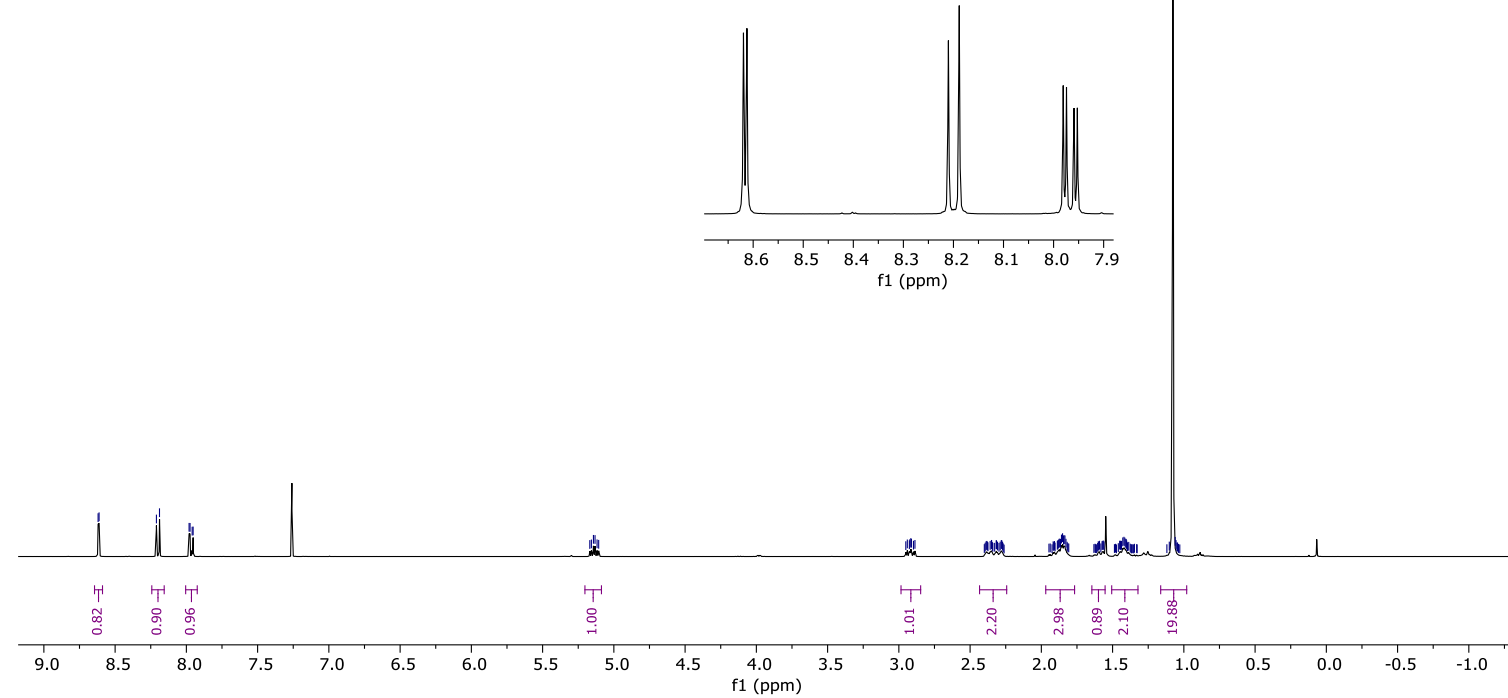

${ }^{13} \mathrm{C}$ NMR (100 MHz, $\mathrm{CDCl}_{3}$ ) of compound $8 \mathrm{r}$ :
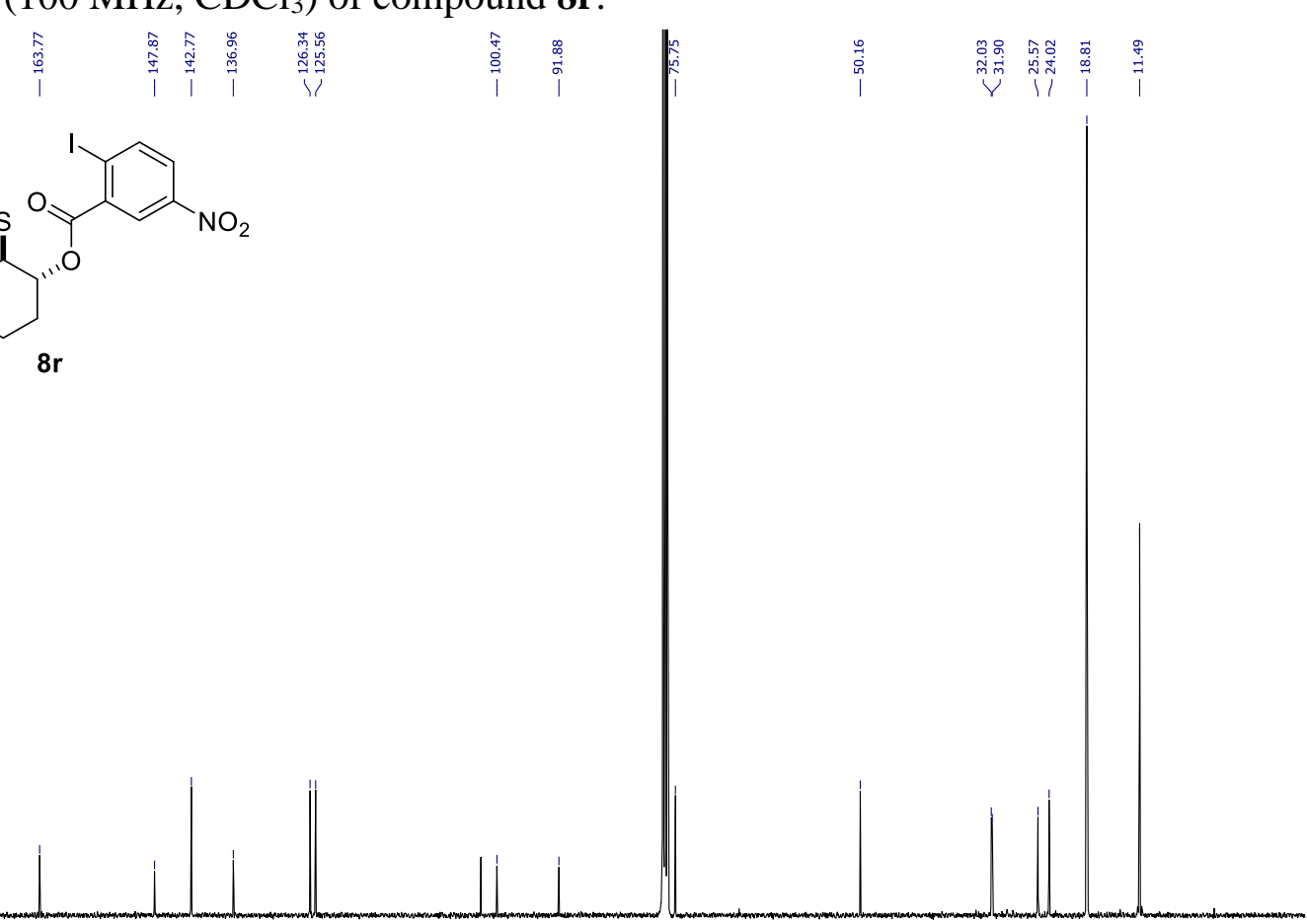

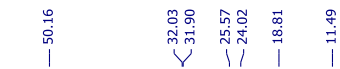<smiles>CC(C)SC#CSC1CCCC[C@H]1OC(=O)c1cc([N+](=O)[O-])ccc1I</smiles>

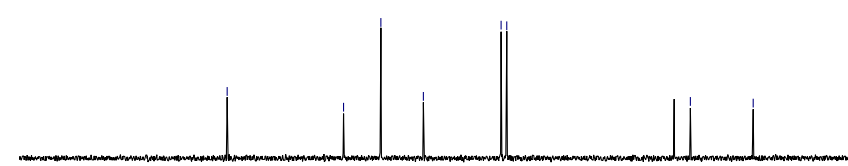


${ }^{1} \mathrm{H}$ NMR $\left(400 \mathrm{MHz}, \mathrm{CDCl}_{3}\right)$ of compound $\mathbf{8 s :}$

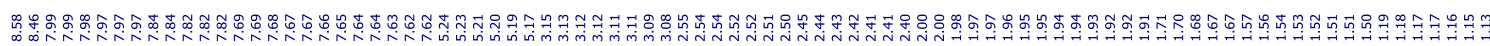<smiles>CC(C)C#CSC1CCCCC1OC(=O)c1cc2ccccc2cc1I</smiles>
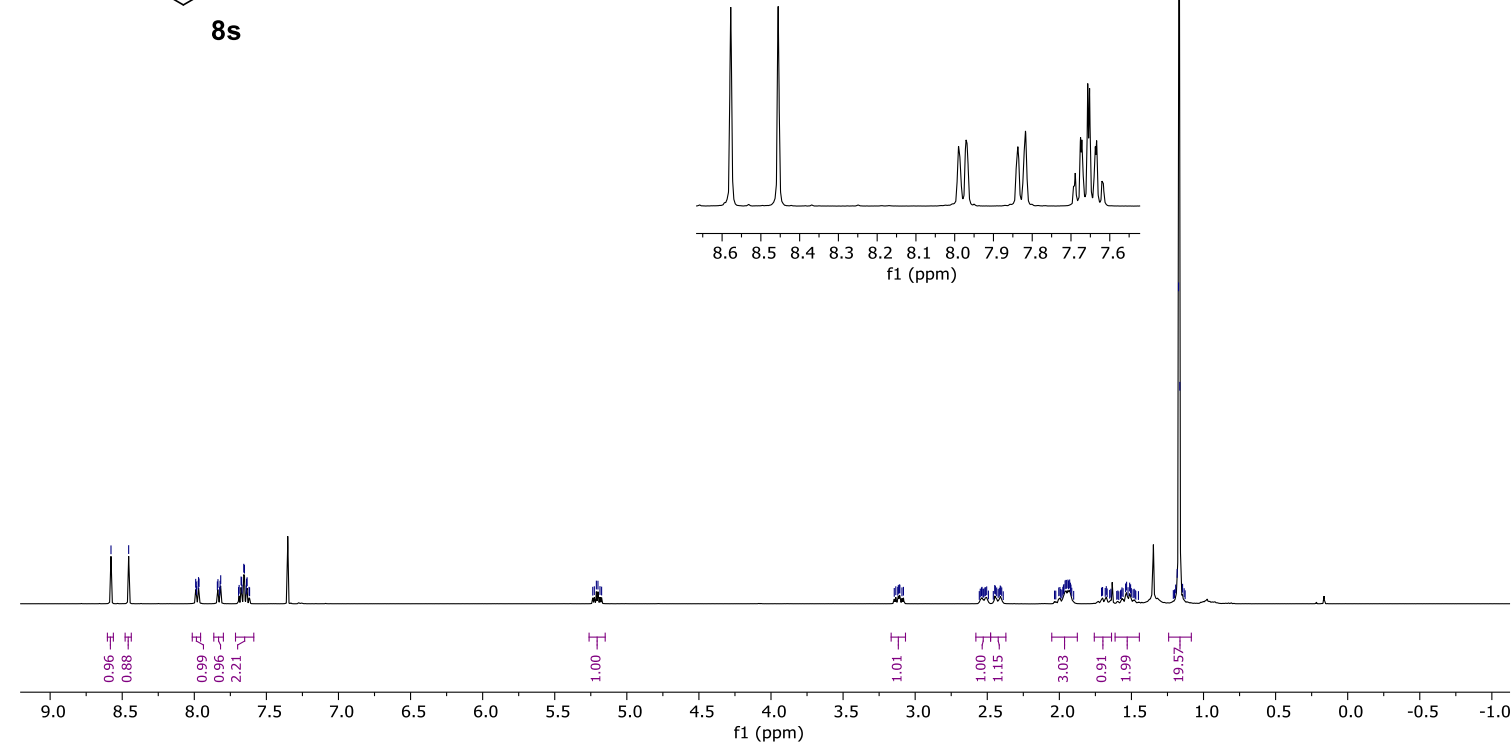

${ }^{13} \mathrm{C}$ NMR $\left(100 \mathrm{MHz}, \mathrm{CDCl}_{3}\right)$ of compound $\mathbf{8 s}$ :

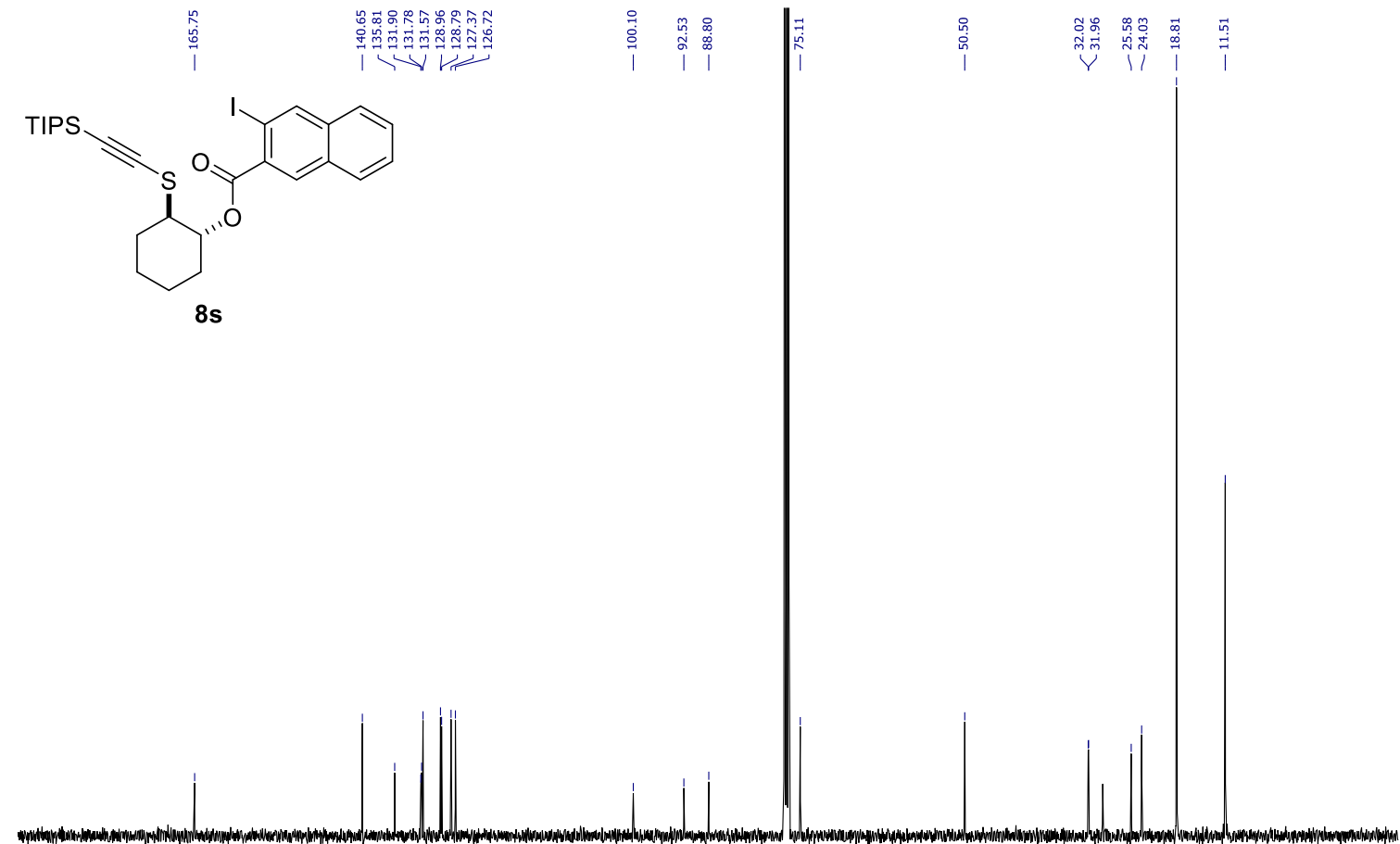

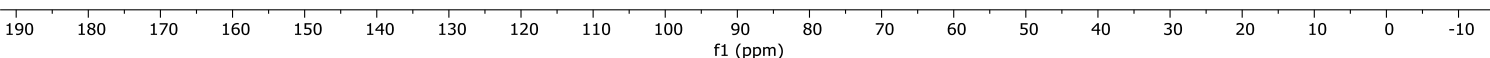


${ }^{1} \mathrm{H}$ NMR (400 MHz, $\mathrm{CDCl}_{3}$ ) of compound $\mathbf{8 t}$ :

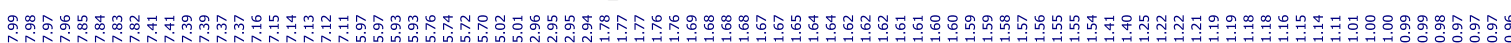

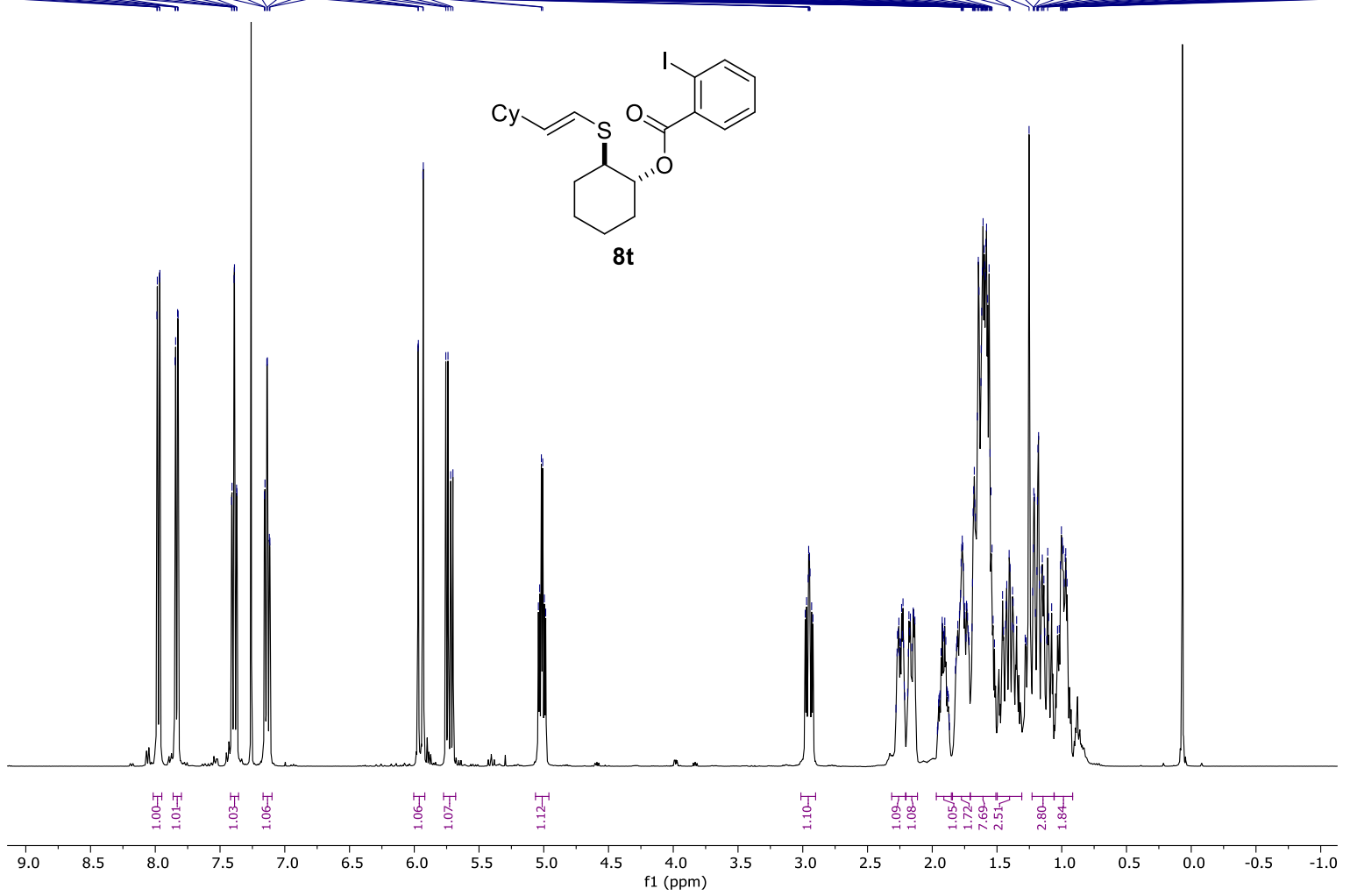

${ }^{13} \mathrm{C}$ NMR (100 MHz, $\mathrm{CDCl}_{3}$ ) of compound 8t:

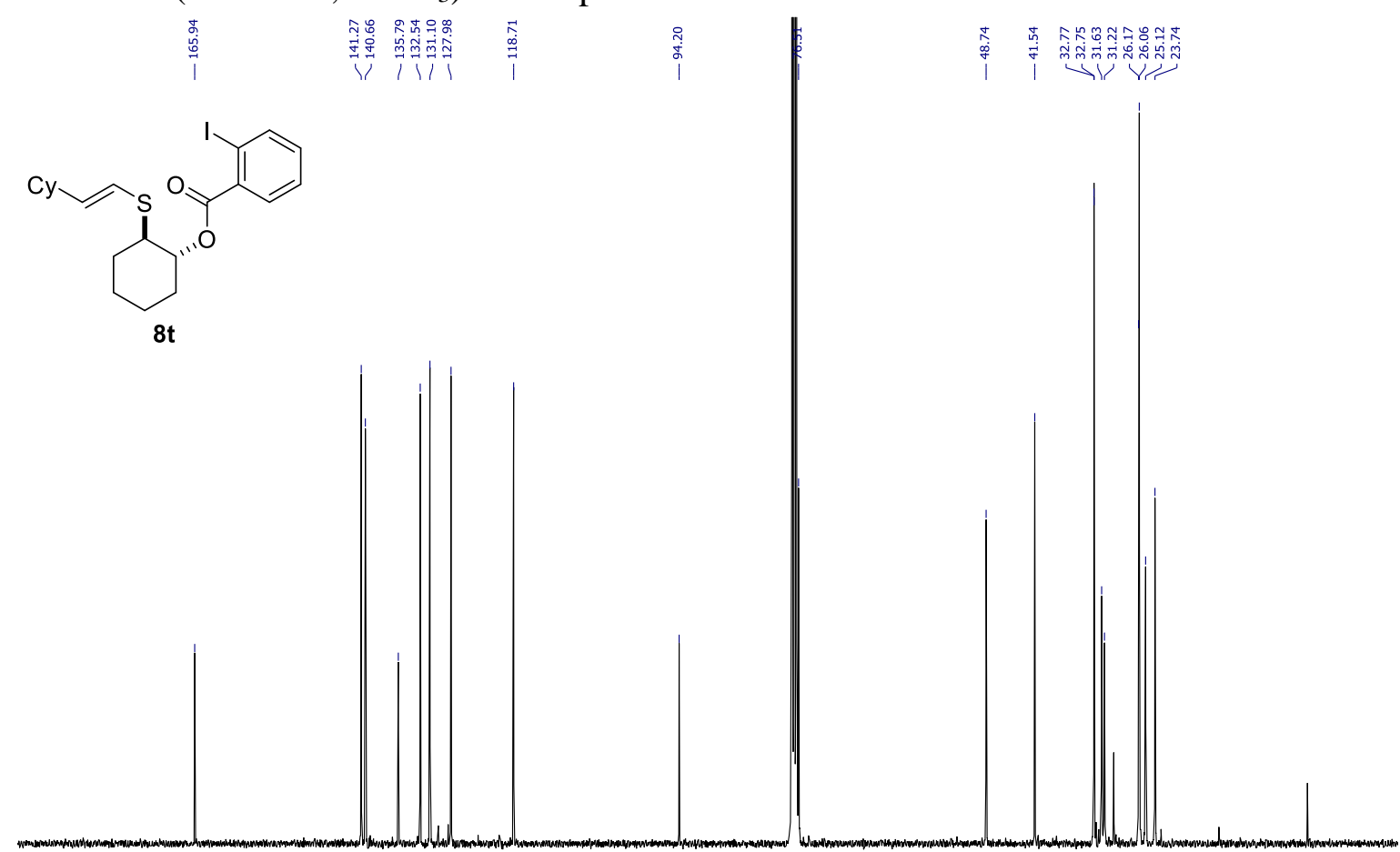

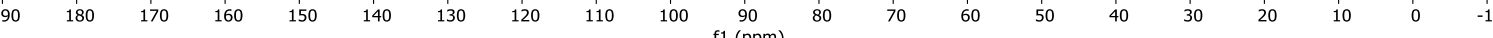


${ }^{1} \mathrm{H}$ NMR (400 MHz, $\mathrm{CDCl}_{3}$ ) of compound $\mathbf{8 u}$ :

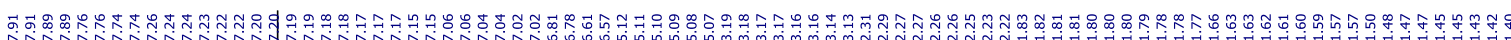

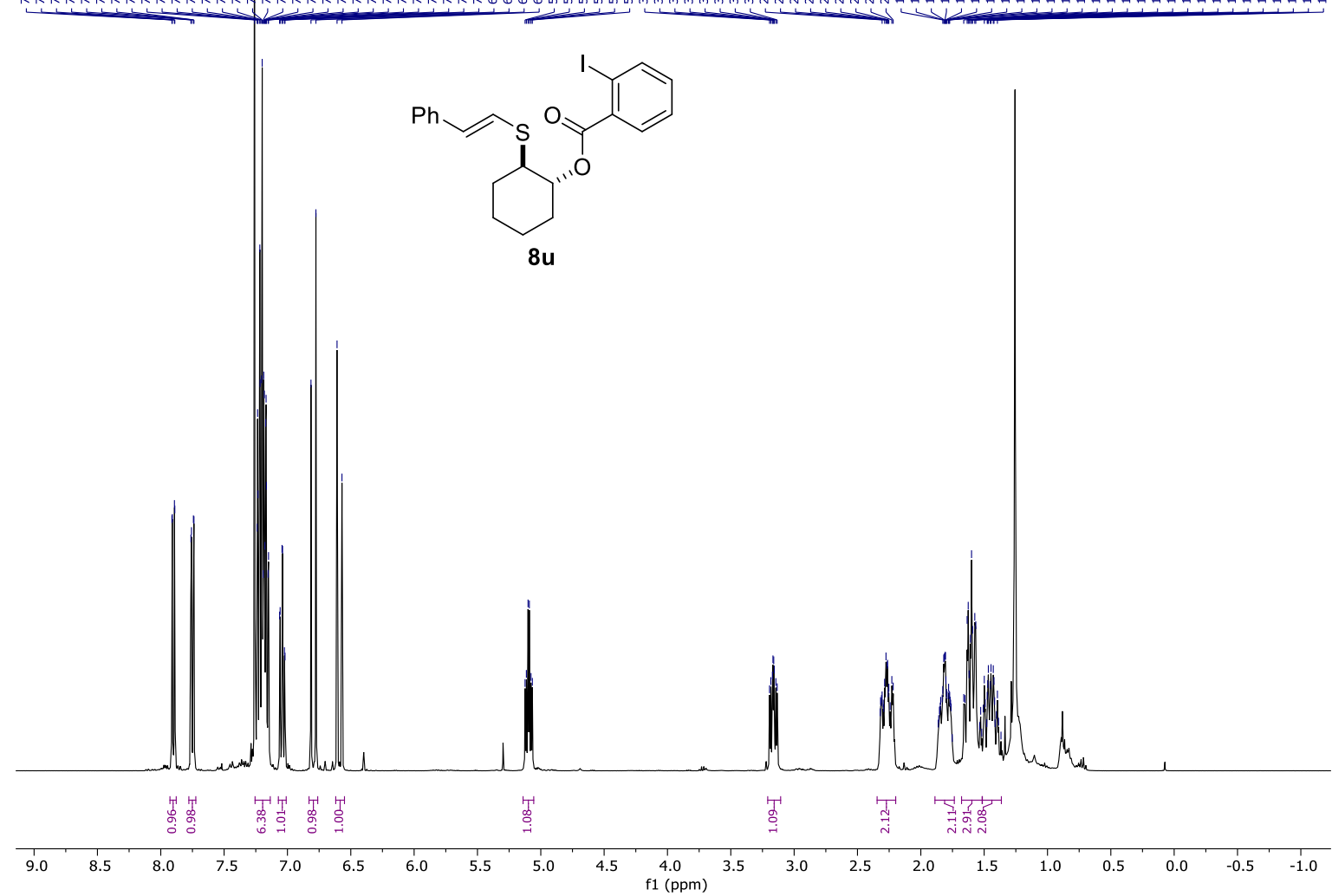

${ }^{13} \mathrm{C}$ NMR $\left(100 \mathrm{MHz}, \mathrm{CDCl}_{3}\right)$ of compound $\mathbf{8 u}$ :

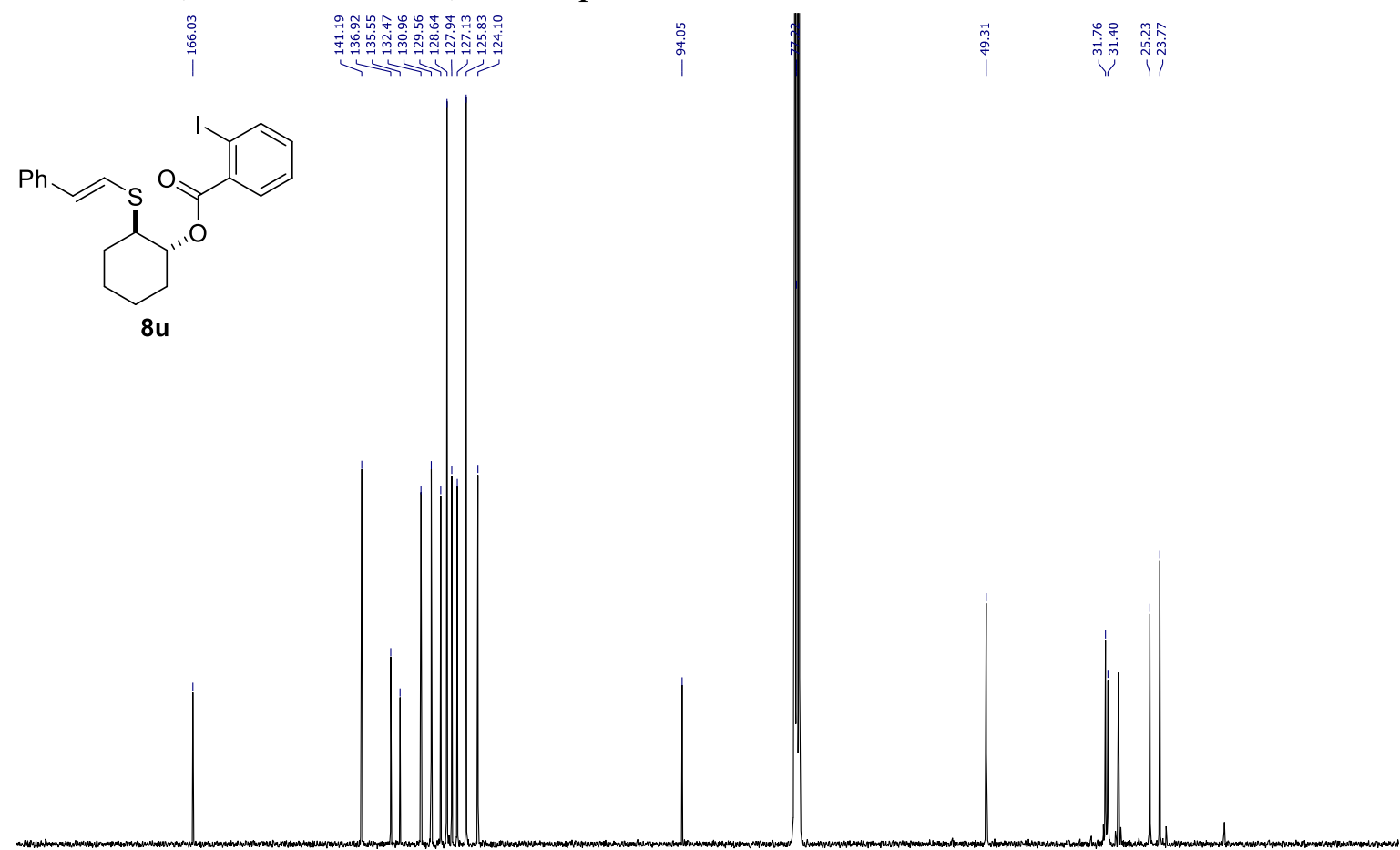

$\begin{array}{lllllllll}170 & 160 & 150 & 140 & 130 & 120 & 110 & 100 & 90 \\ & 130 & & & & & & \end{array}$

$\quad 70 \quad 60$

$30+20,10, \frac{1}{1}, \frac{1}{1}$ 
${ }^{1} \mathrm{H}$ NMR (400 MHz, $\mathrm{CDCl}_{3}$ ) of compound $\mathbf{8 v}$ :

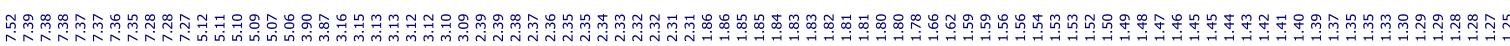<smiles>COc1cc(I)c(C(=O)OC2CCCCC2SC#Cc2ccccc2)cc1OC</smiles>

$8 v$

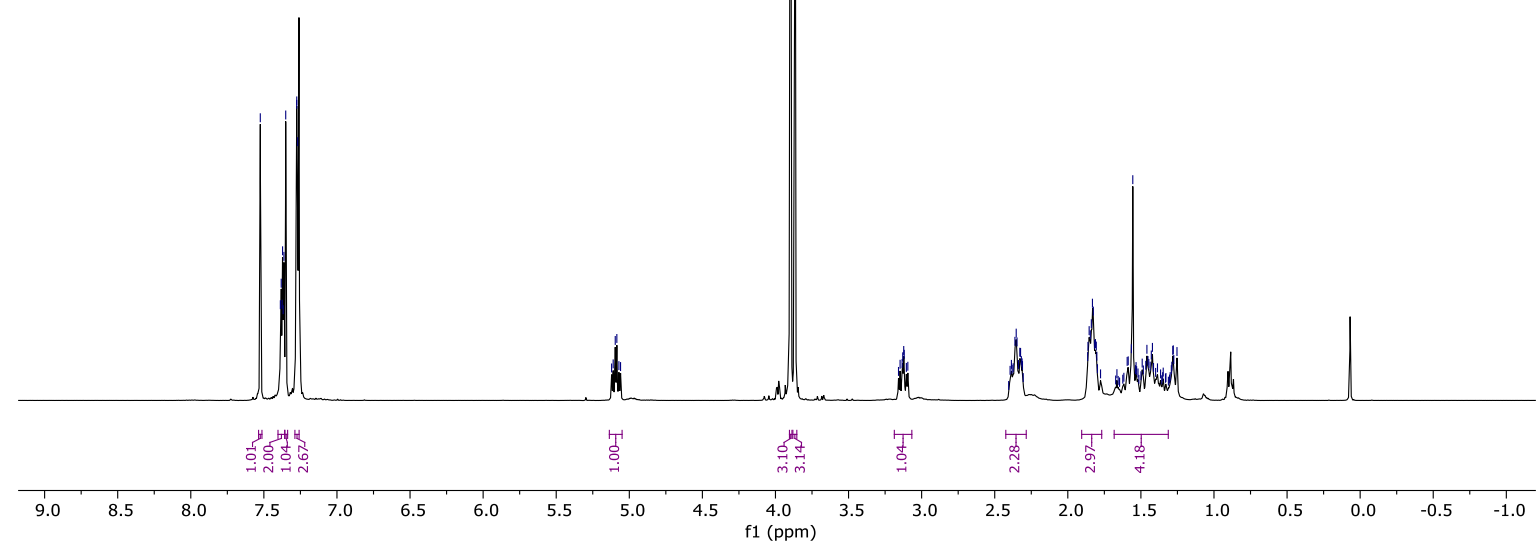

${ }^{13} \mathrm{C}$ NMR $\left(100 \mathrm{MHz}, \mathrm{CDCl}_{3}\right)$ of compound $\mathbf{8 v}$ :

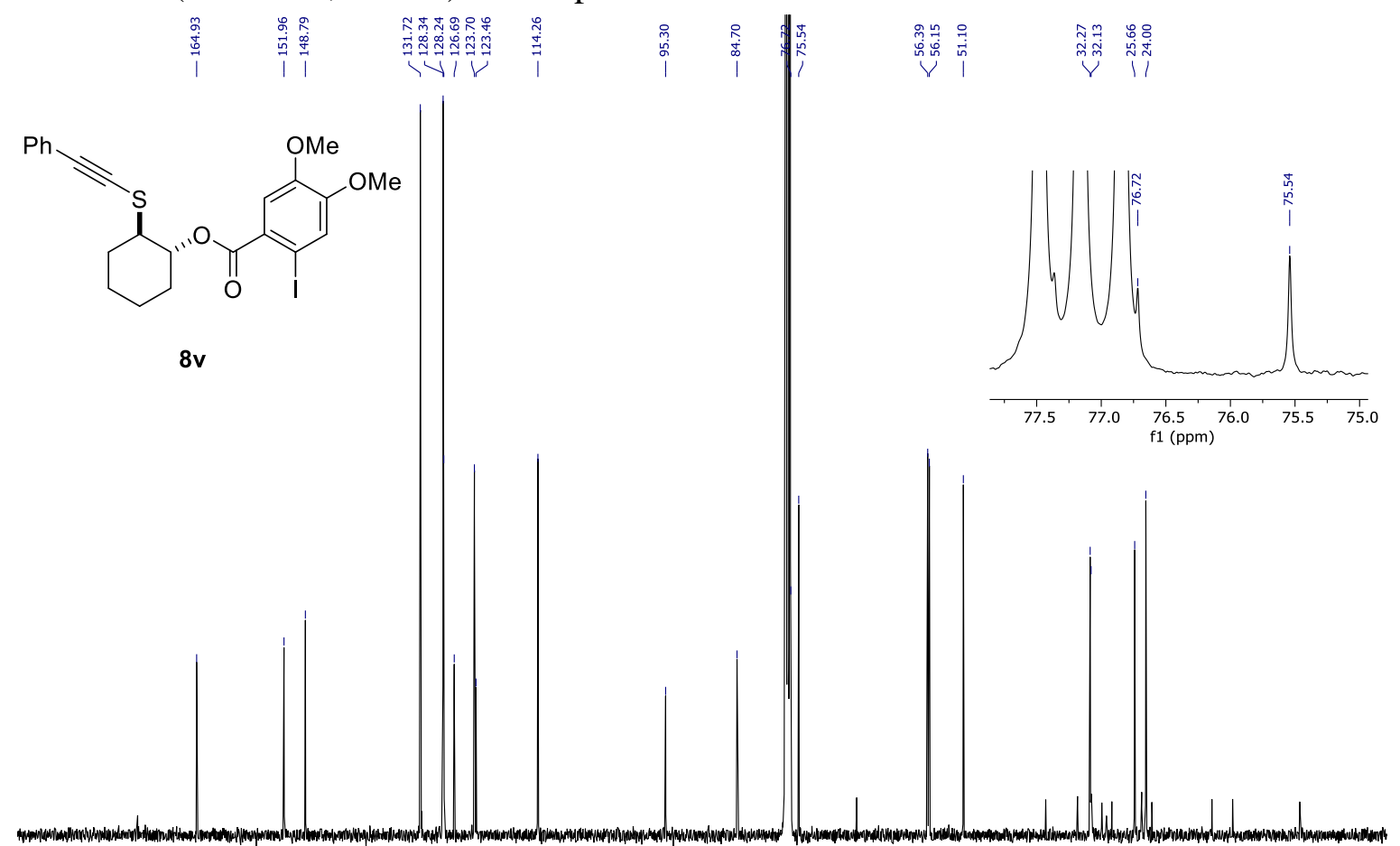

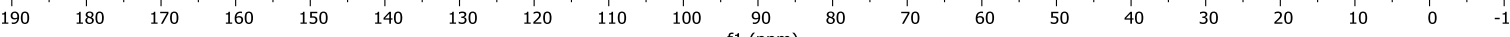


${ }^{1} \mathrm{H} \mathrm{NMR}\left(400 \mathrm{MHz}, \mathrm{CDCl}_{3}\right.$ ) of compound $\mathbf{8 w}$ :

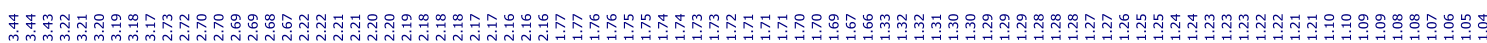

TIPS

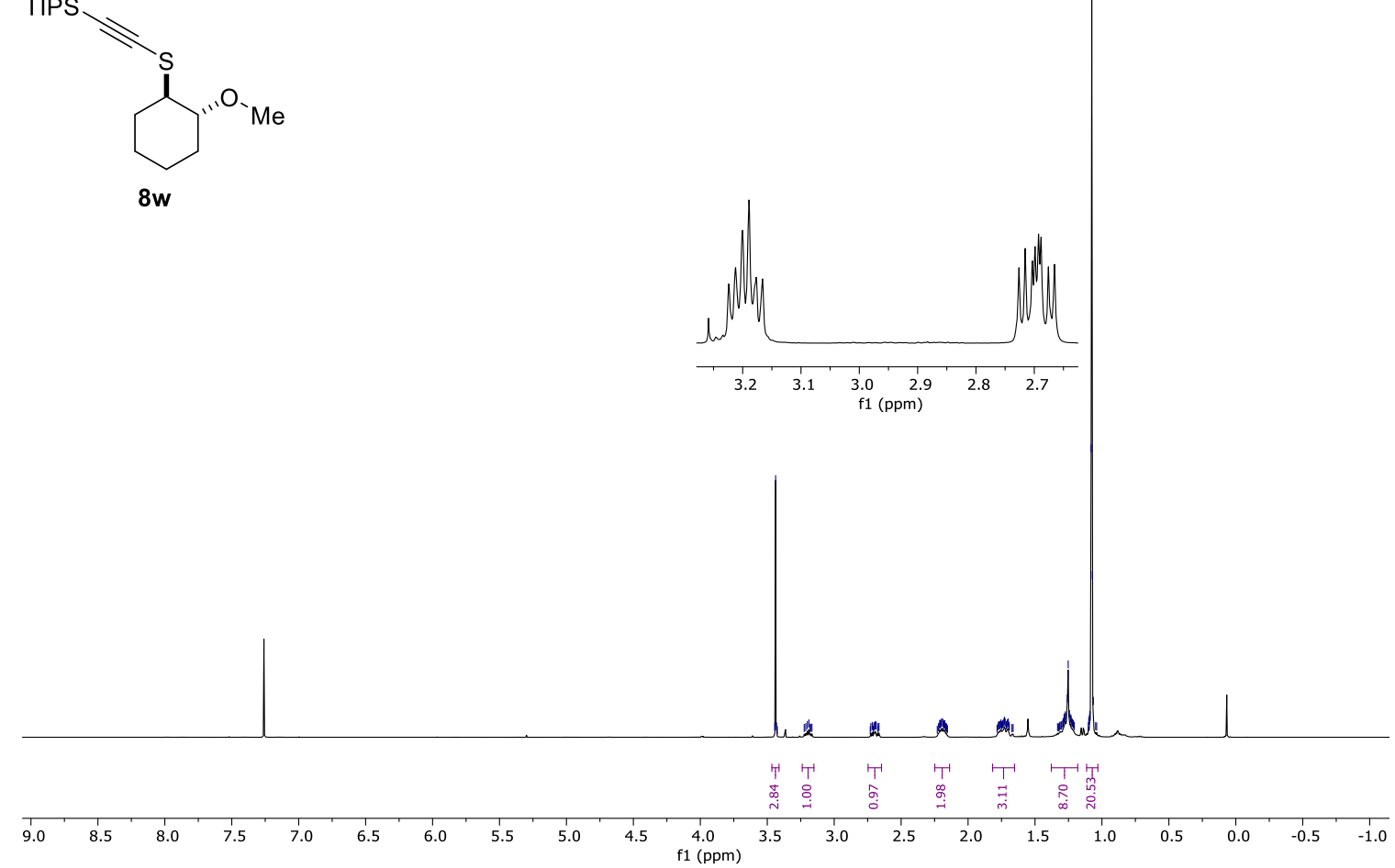

$8 w$
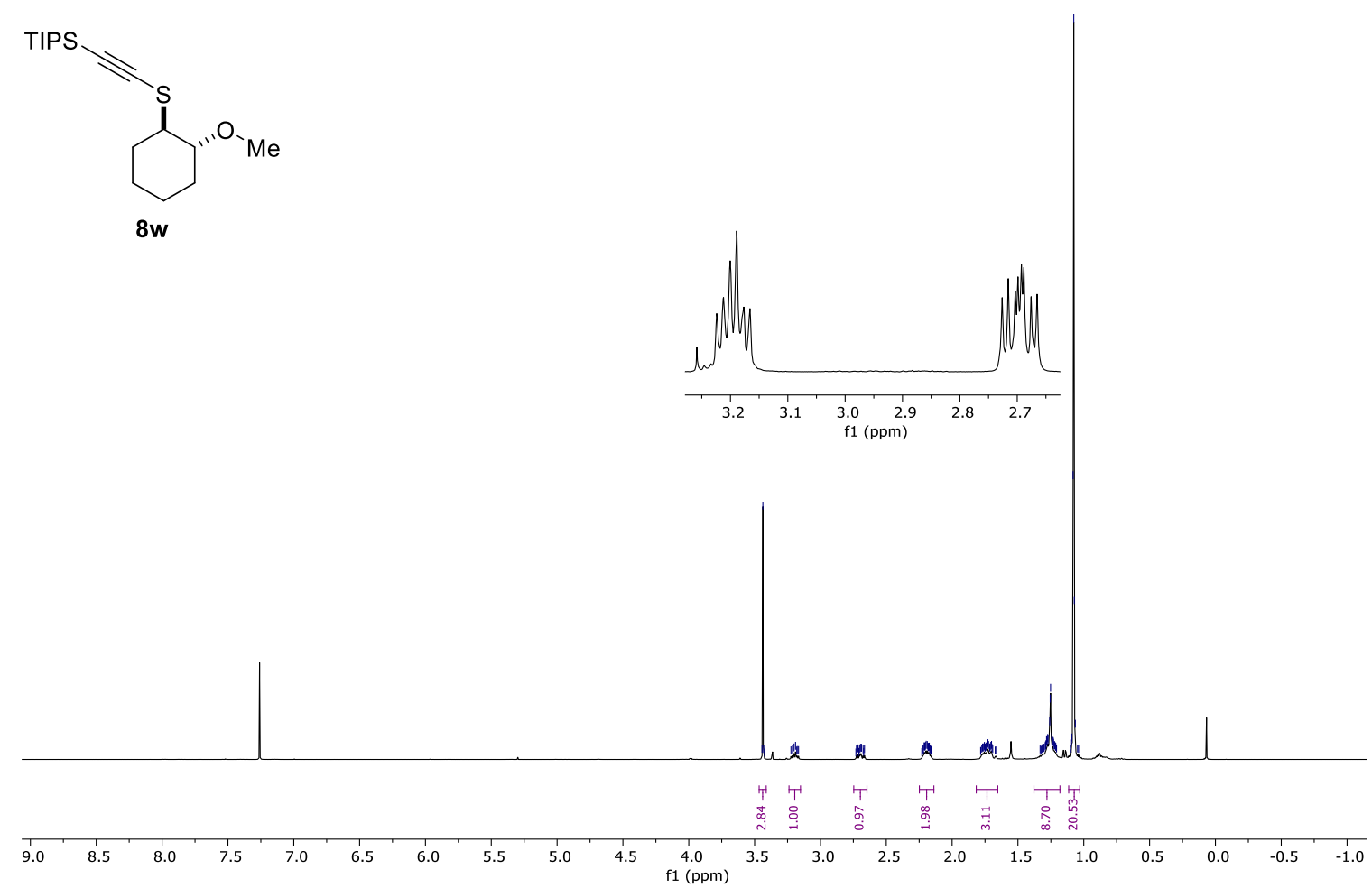

${ }^{13} \mathrm{C}$ NMR (100 MHz, $\left.\mathrm{CDCl}_{3}\right)$ of compound 8w:

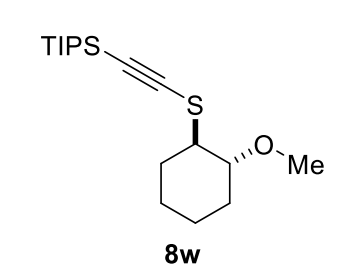

$8 w$

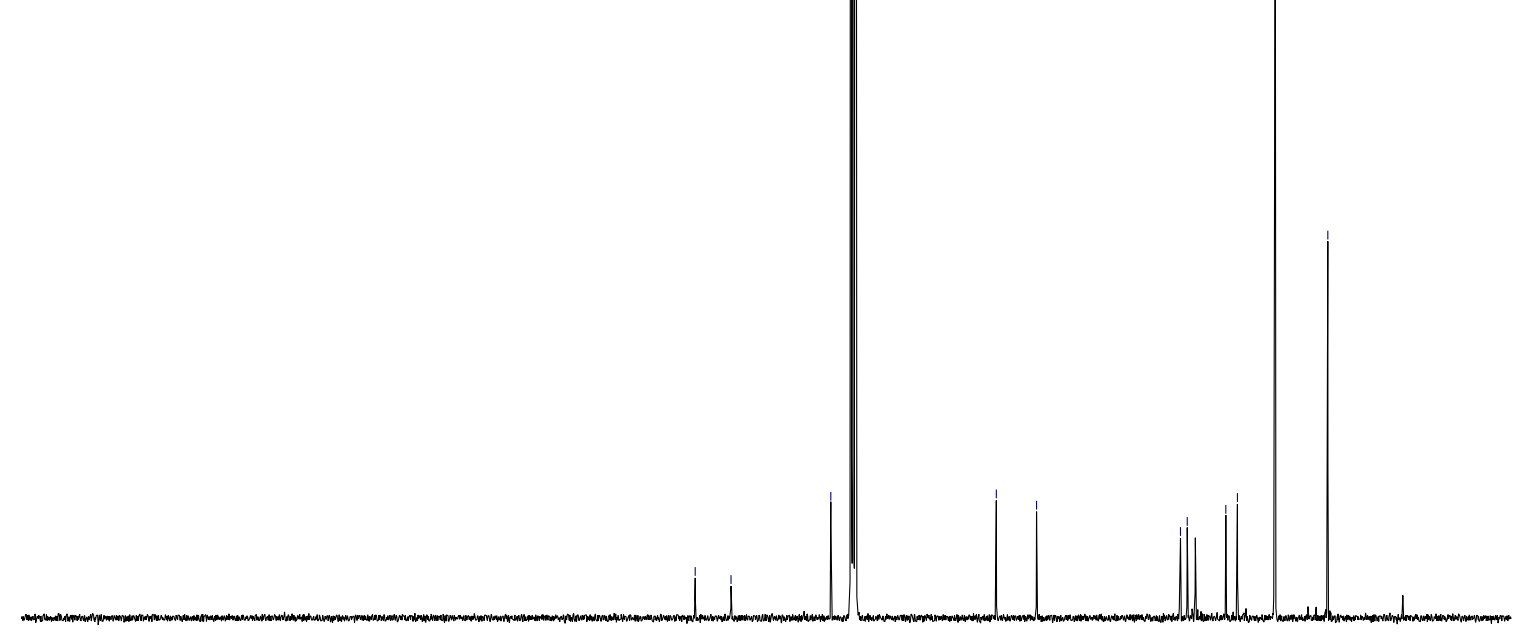

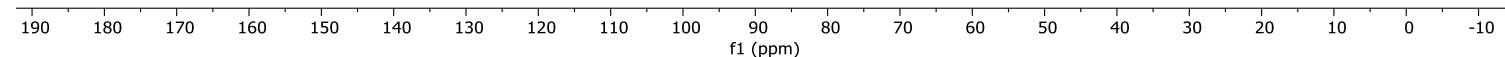


${ }^{1} \mathrm{H} \mathrm{NMR}\left(400 \mathrm{MHz}, \mathrm{CDCl}_{3}\right.$ ) of compound $\mathbf{9 d}$ :
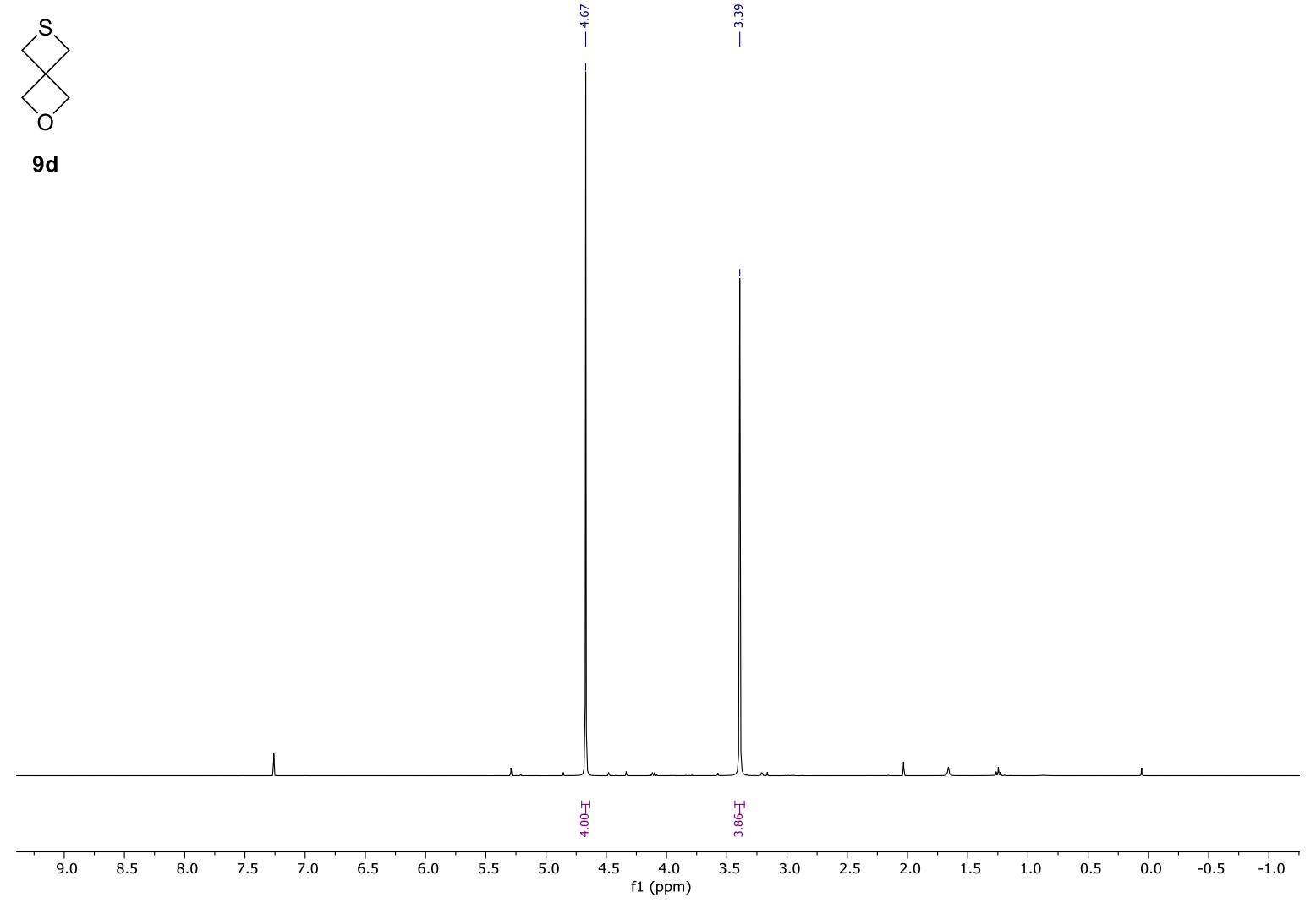

${ }^{13} \mathrm{C} \mathrm{NMR}\left(100 \mathrm{MHz}, \mathrm{CDCl}_{3}\right)$ of compound 9d:

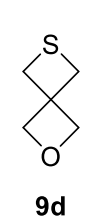

9d

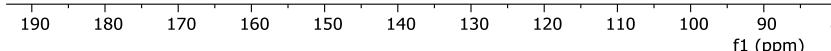


${ }^{1} \mathrm{H}$ NMR (400 MHz, $\mathrm{CDCl}_{3}$ ) of compound 10a:

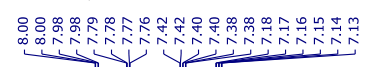

学亭势

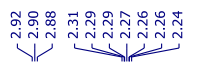

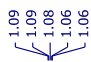

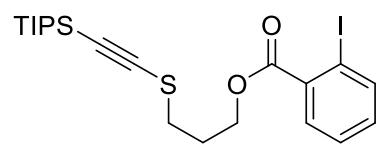

$10 a$
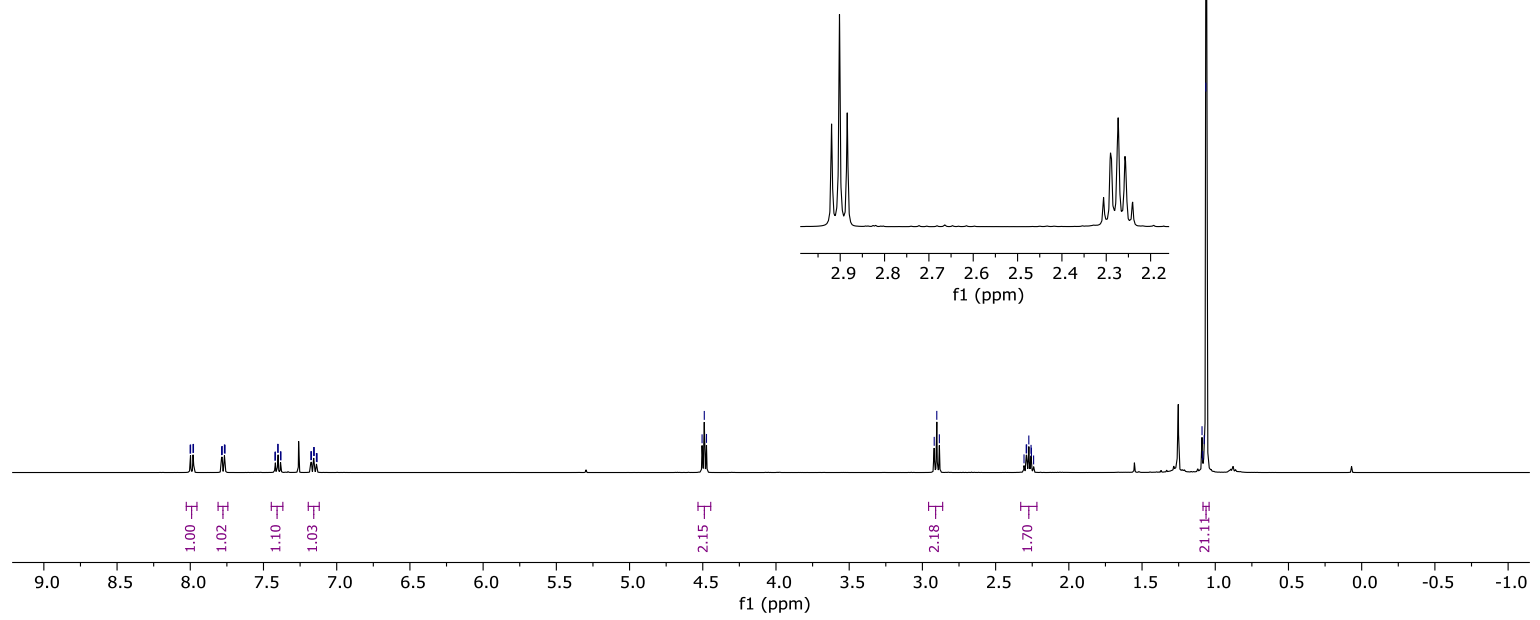

${ }^{13} \mathrm{C}$ NMR (100 MHz, $\left.\mathrm{CDCl}_{3}\right)$ of compound 10a:

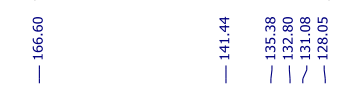

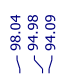

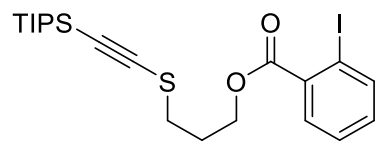

$10 a$
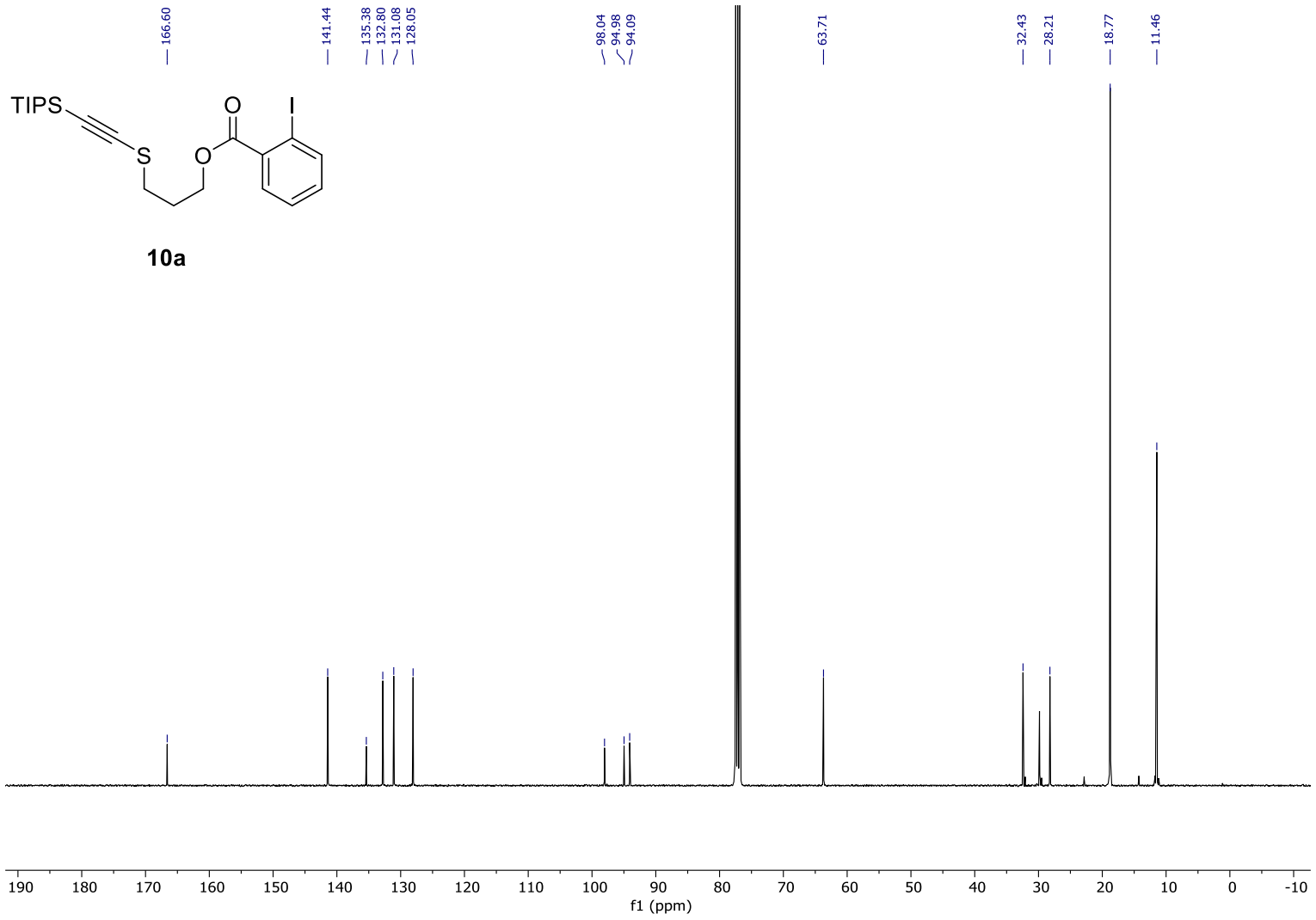

S92 
${ }^{1} \mathrm{H}$ NMR (400 MHz, $\left.\mathrm{CDCl}_{3}\right)$ of compound $\mathbf{1 0 b}$ :

$\underbrace{\underbrace{}_{n}}$

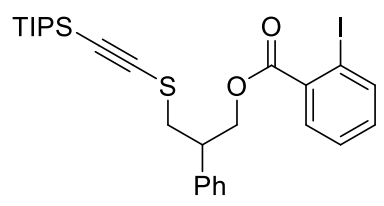

$10 \mathrm{~b}$
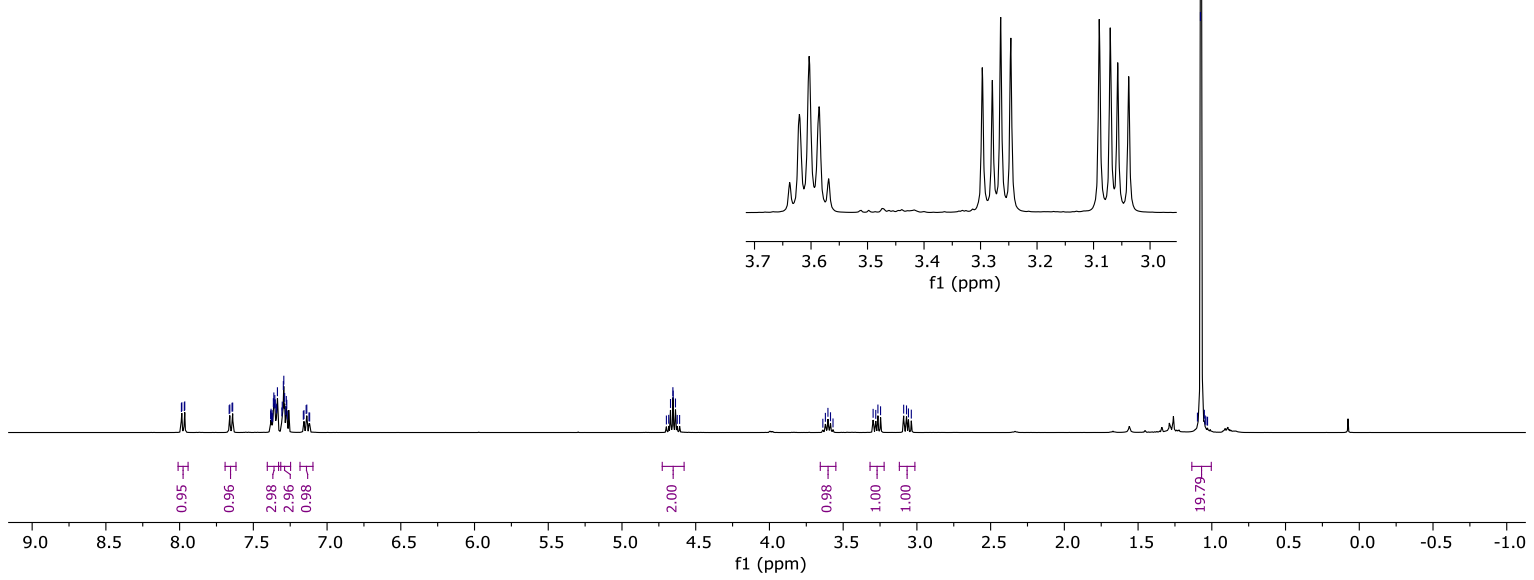

${ }^{13} \mathrm{C}$ NMR $\left(100 \mathrm{MHz}, \mathrm{CDCl}_{3}\right)$ of compound $\mathbf{1 0 b}$ :
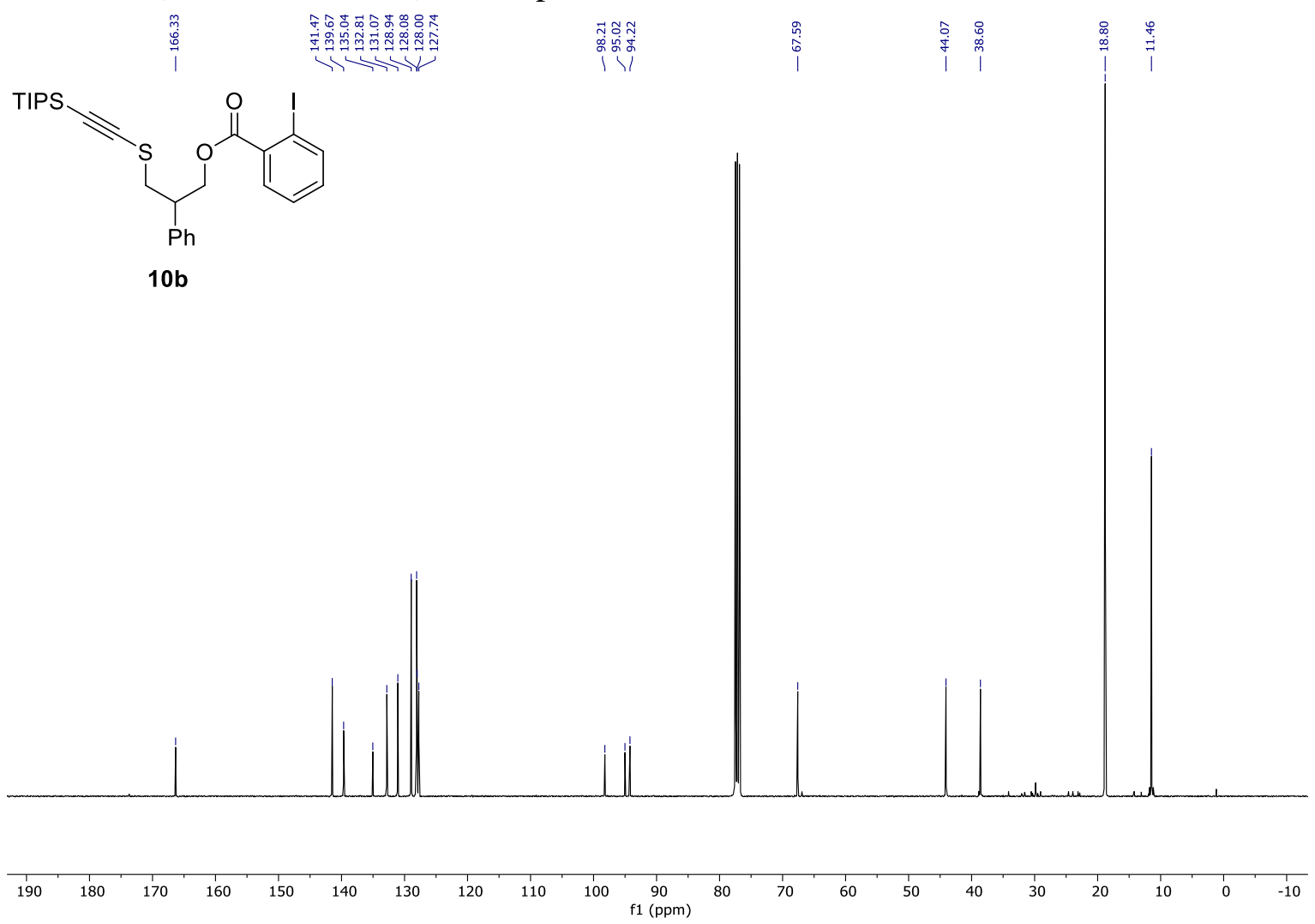

S93 
${ }^{1} \mathrm{H}$ NMR (400 MHz, $\mathrm{CDCl}_{3}$ ) of compound 10c:

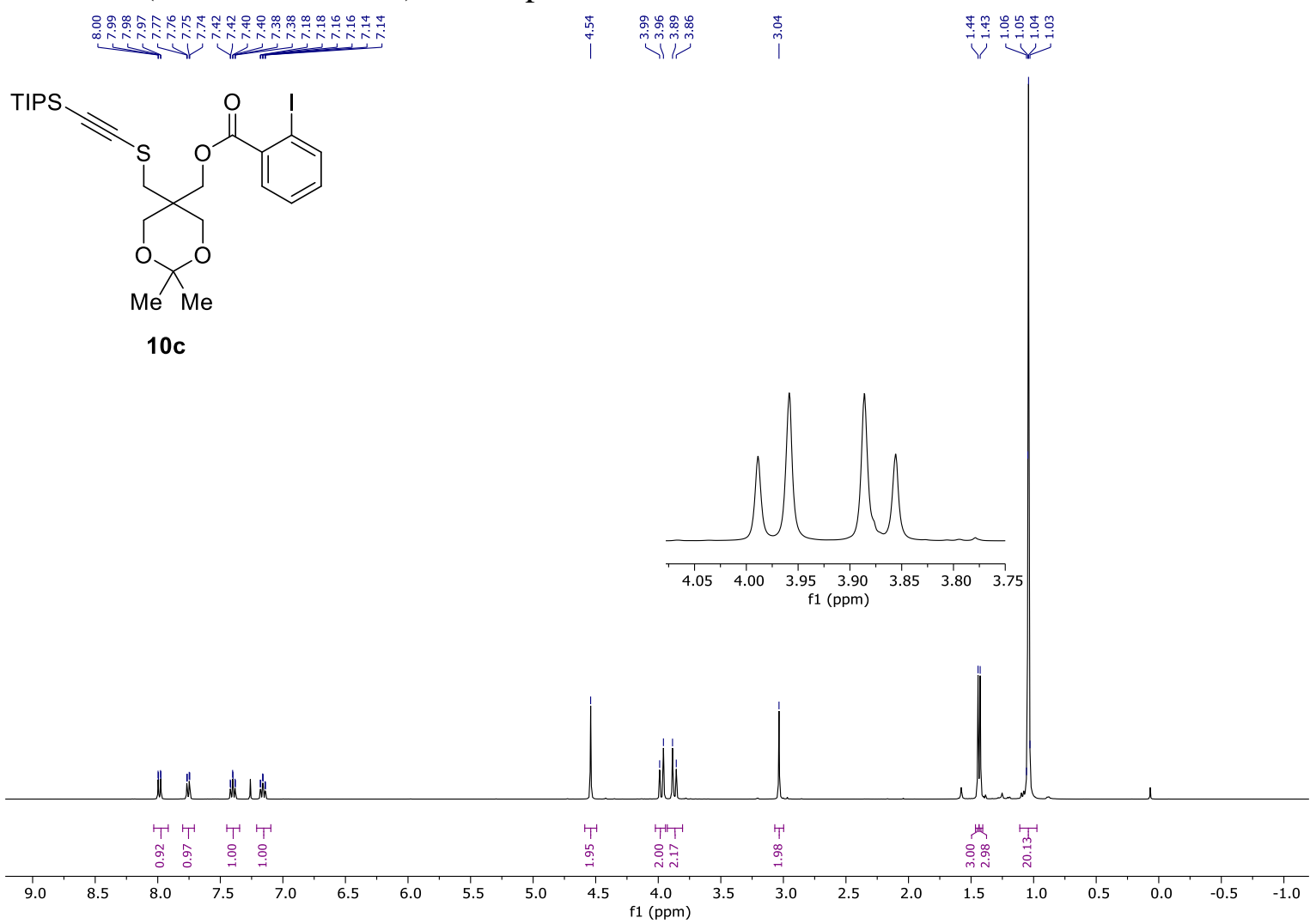

${ }^{13} \mathrm{C}$ NMR (100 MHz, $\mathrm{CDCl}_{3}$ ) of compound 10c:

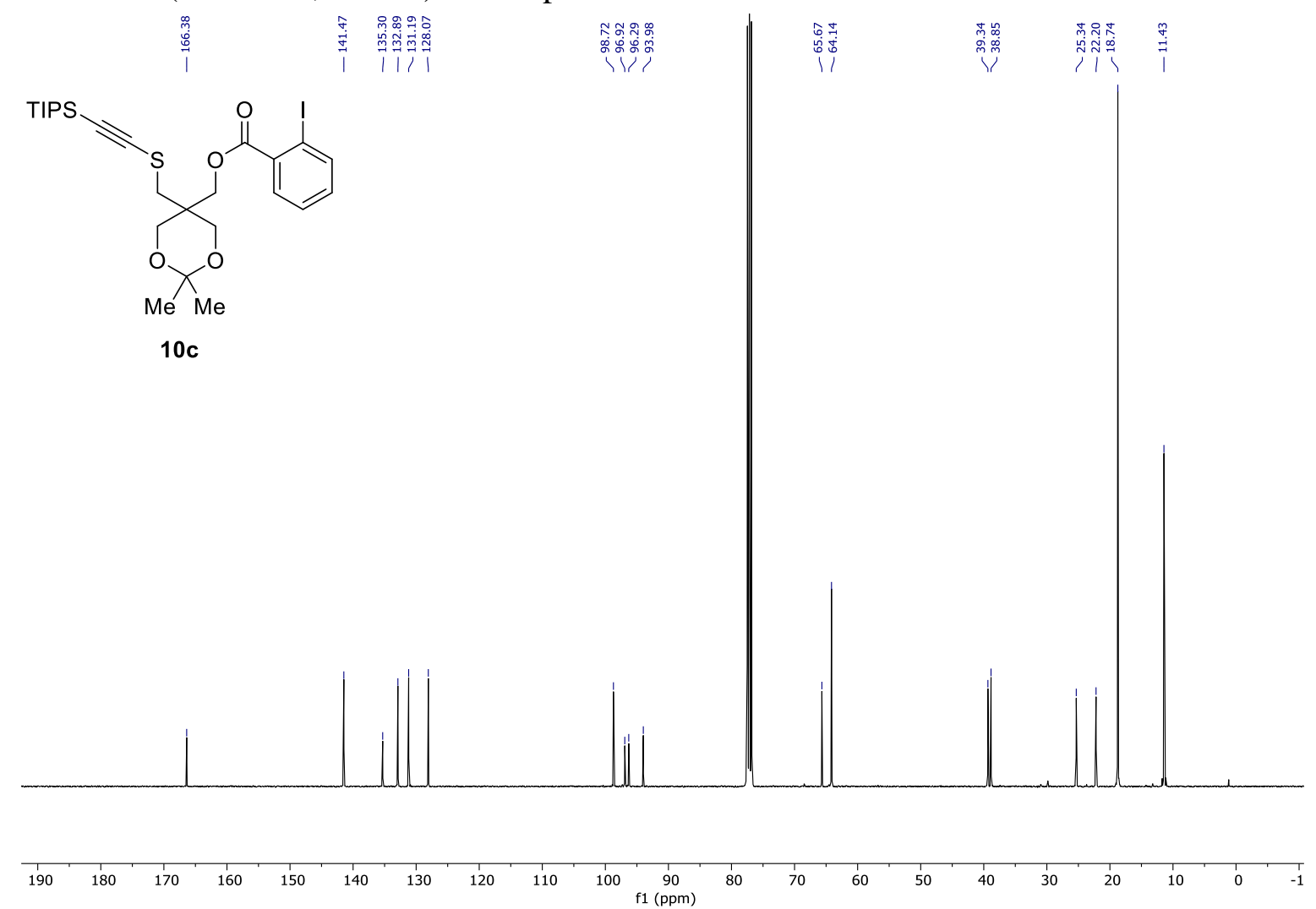


${ }^{1} \mathrm{H}$ NMR (400 MHz, $\mathrm{CDCl}_{3}$ ) of compound $\mathbf{1 0 d}$ :

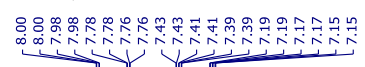

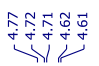

$\stackrel{\circ}{i}$

ขึن
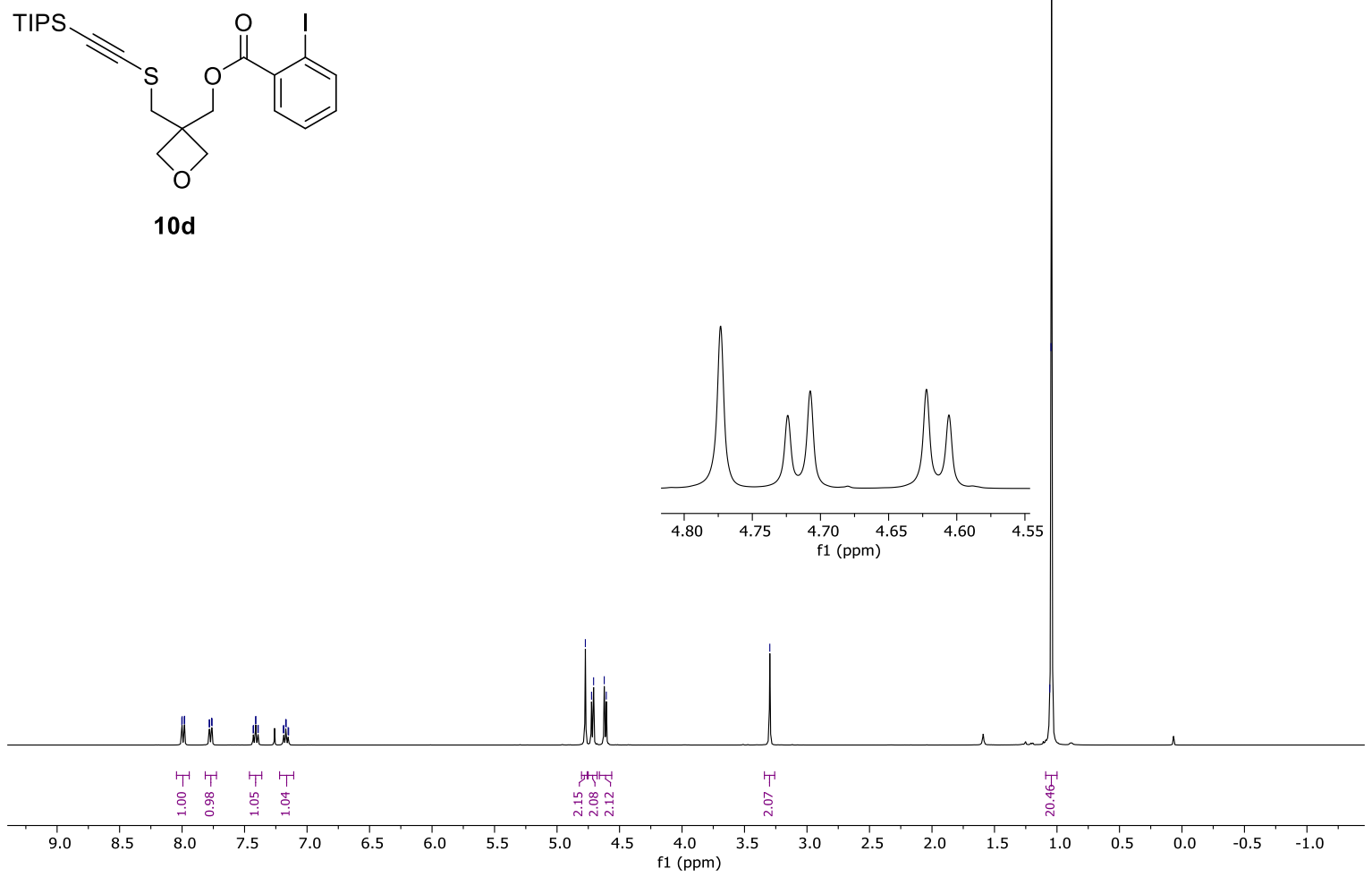

${ }^{13} \mathrm{C}$ NMR (100 MHz, $\left.\mathrm{CDCl}_{3}\right)$ of compound 10d:
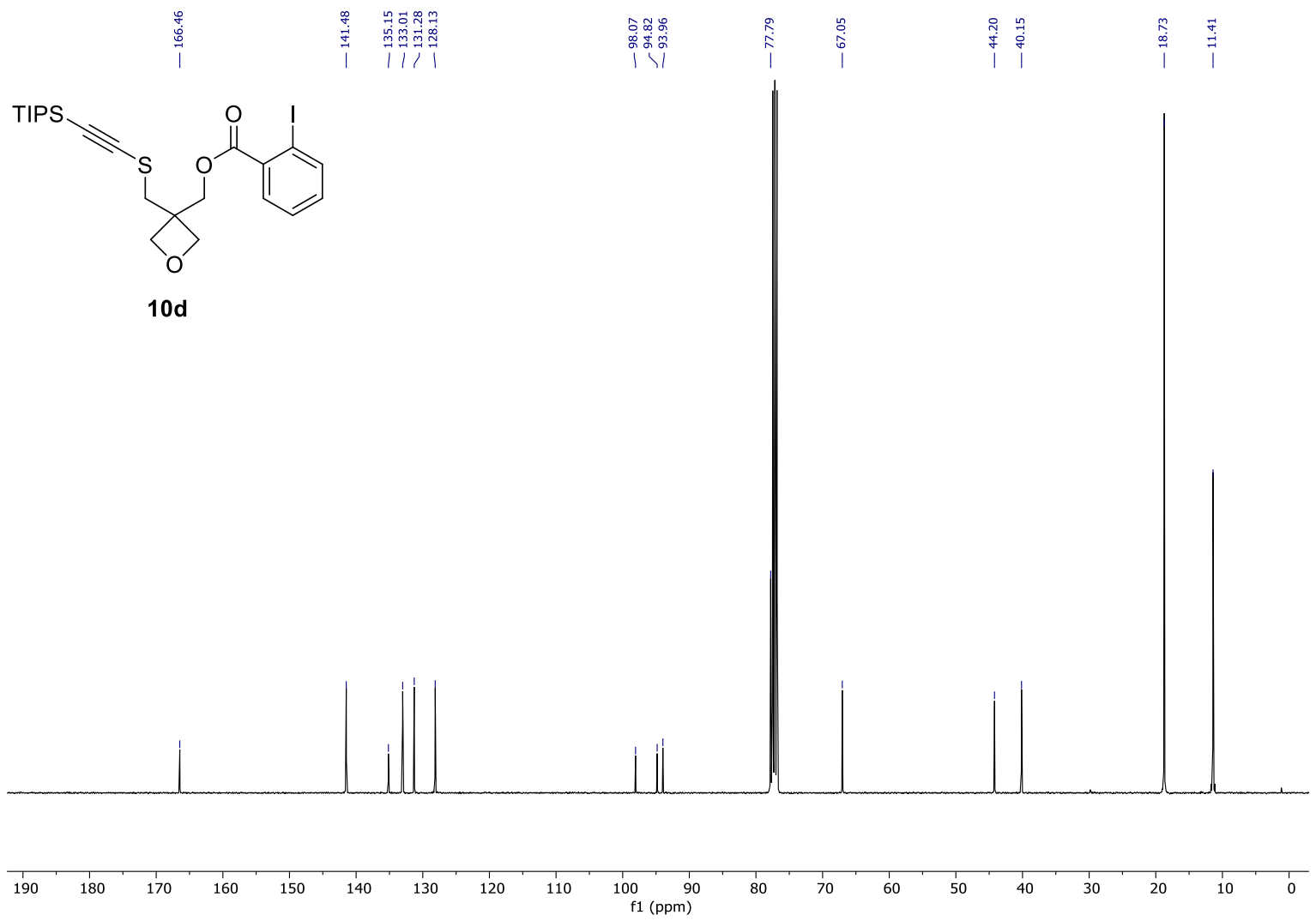

S95 
${ }^{1} \mathrm{H}$ NMR $\left(400 \mathrm{MHz}, \mathrm{CDCl}_{3}\right)$ of compound 10e:

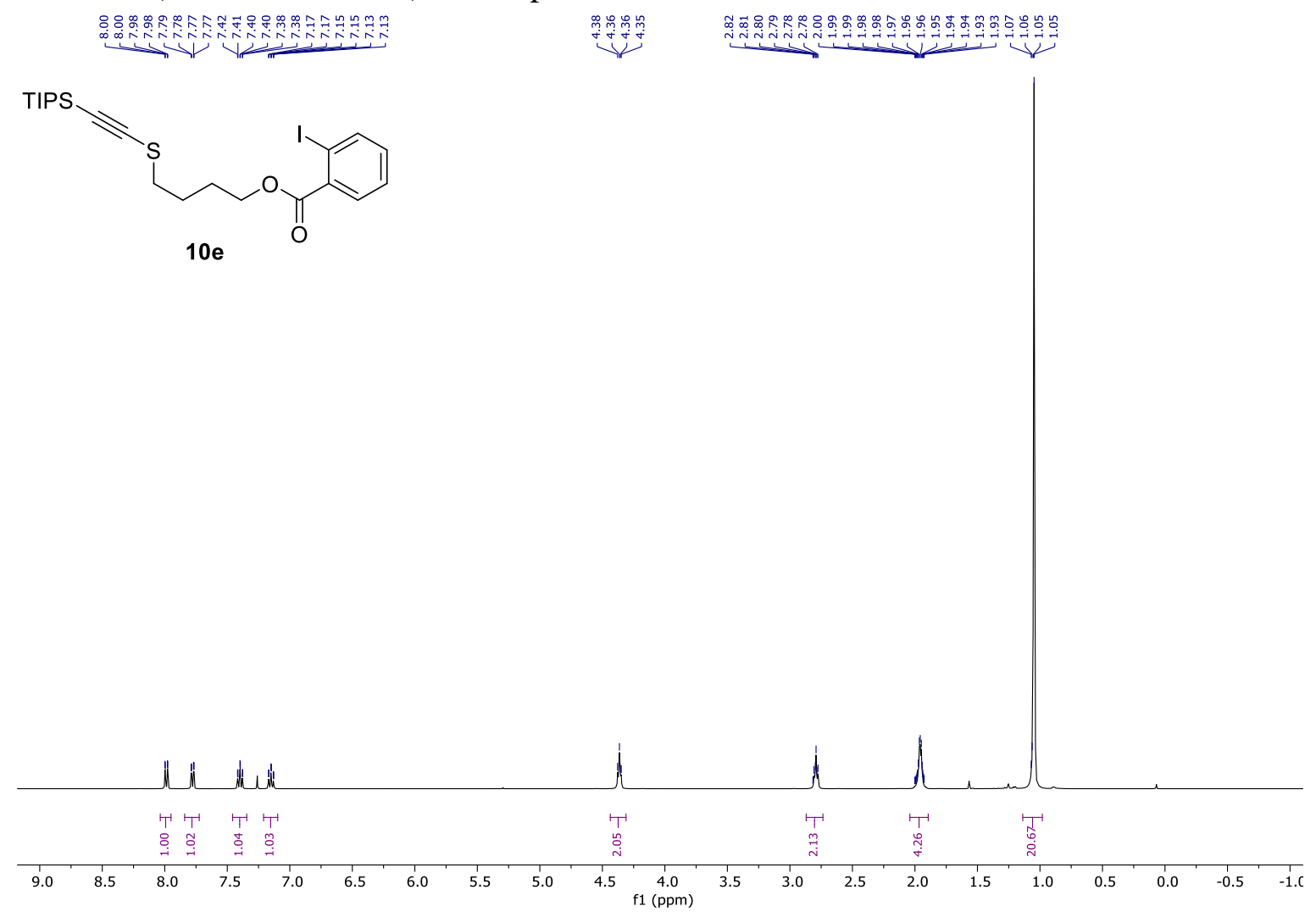

${ }^{13} \mathrm{C}$ NMR $\left(100 \mathrm{MHz}, \mathrm{CDCl}_{3}\right)$ of compound 10e:
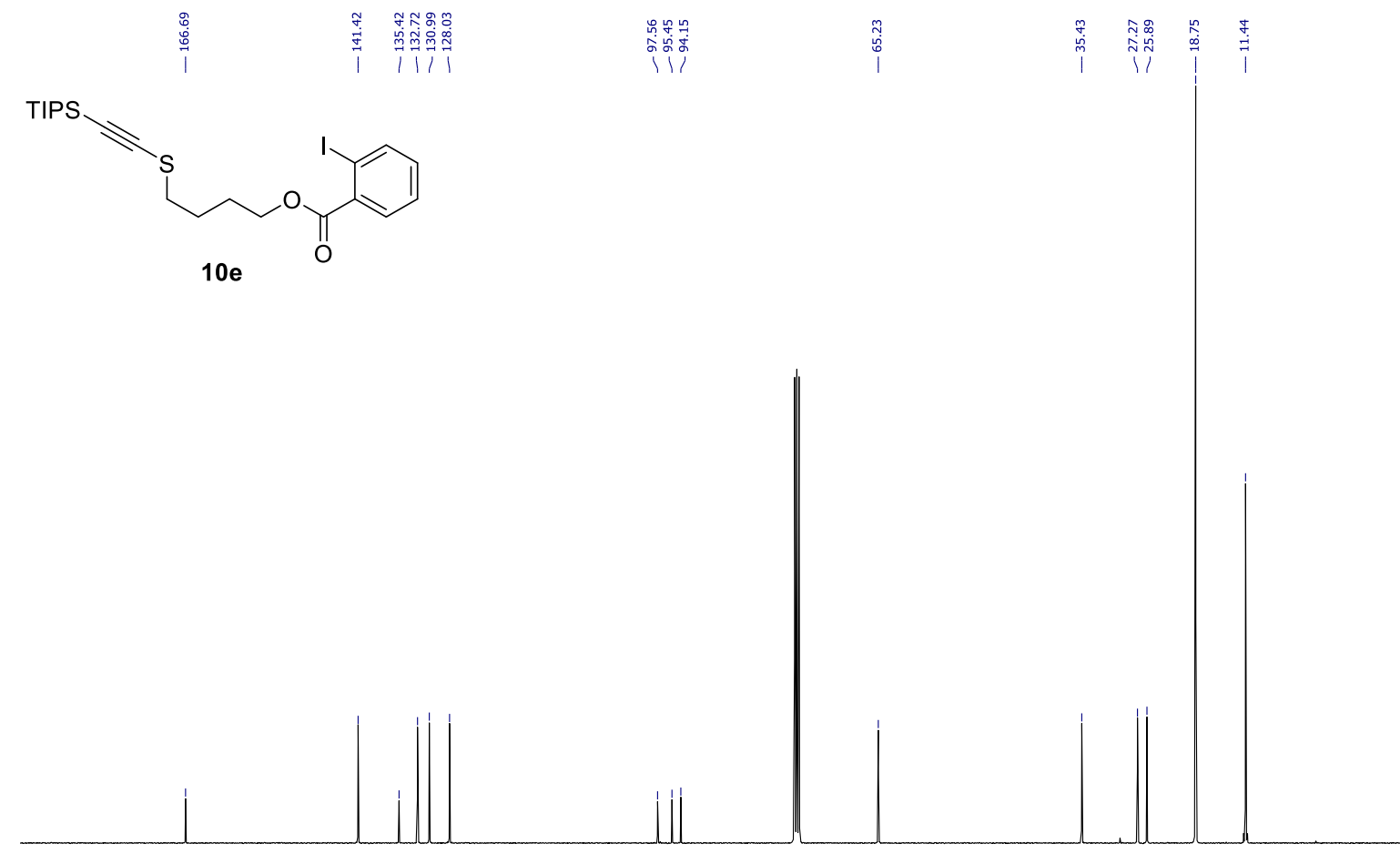

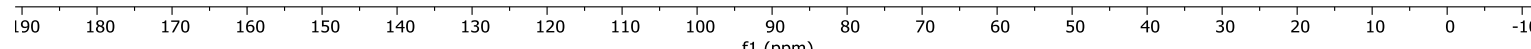


${ }^{1} \mathrm{H} \mathrm{NMR}\left(400 \mathrm{MHz}, \mathrm{CDCl}_{3}\right.$ ) of compound $\mathbf{1 1}$ :

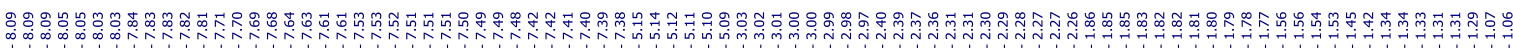<smiles>C[C@@H]1CC[C@H](SC#C[18F])[C@@H](OC(=O)c2ccccc2C#Cc2ccc3ccccc3c2)C1</smiles>

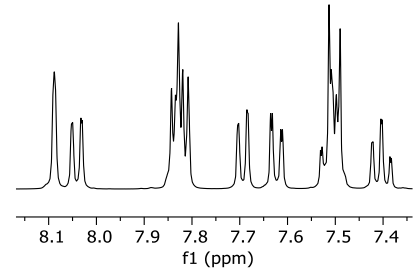

Whilet 管

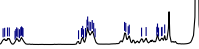

粗

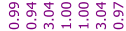

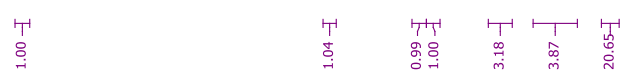

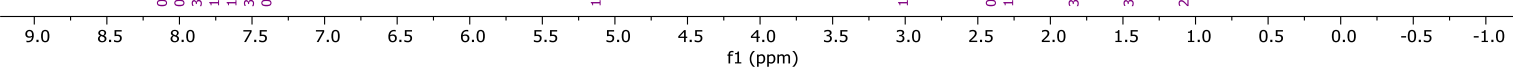

${ }^{13} \mathrm{C}$ NMR (100 MHz, $\left.\mathrm{CDCl}_{3}\right)$ of compound 11:

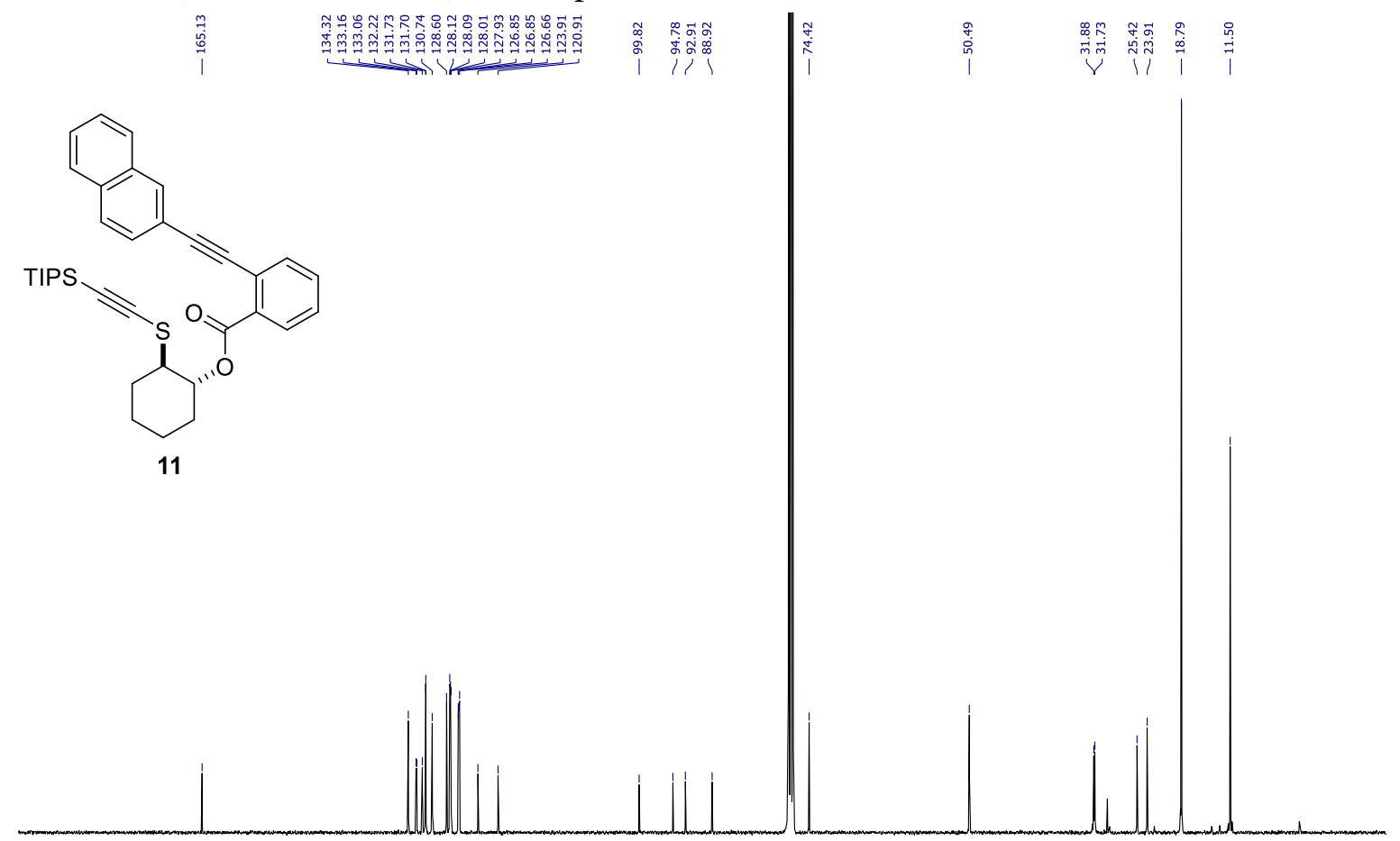

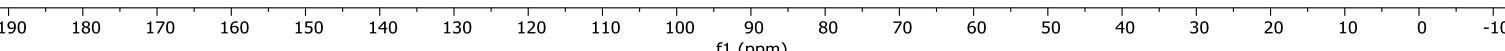


${ }^{1} \mathrm{H}$ NMR (400 MHz, $\mathrm{CDCl}_{3}$ ) of compound $\mathbf{1 2}$ :

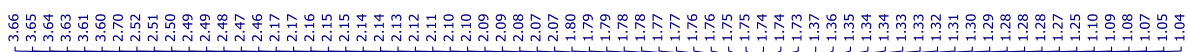<smiles>O[C@H]1CCCCC1SC#C[In]</smiles>

12

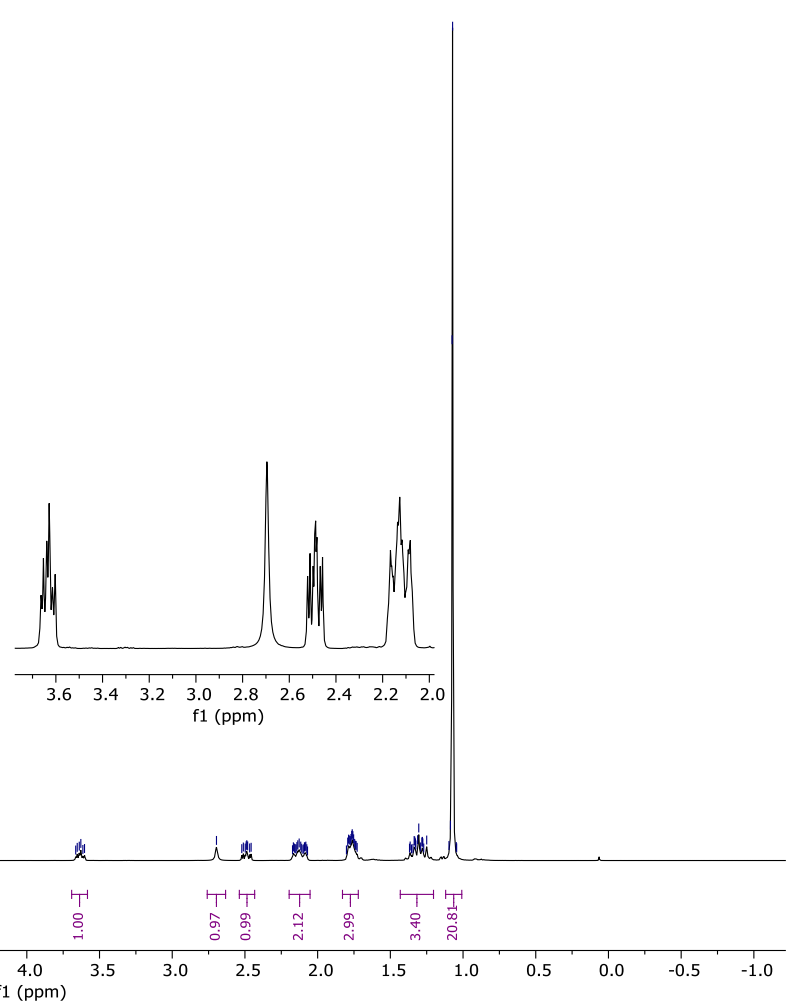

${ }^{13} \mathrm{C}$ NMR $\left(100 \mathrm{MHz}, \mathrm{CDCl}_{3}\right)$ of compound 12:

TIPS

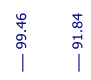

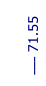

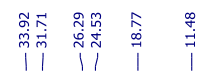<smiles>C#CSC1CCCC[C@H]1O</smiles>

12

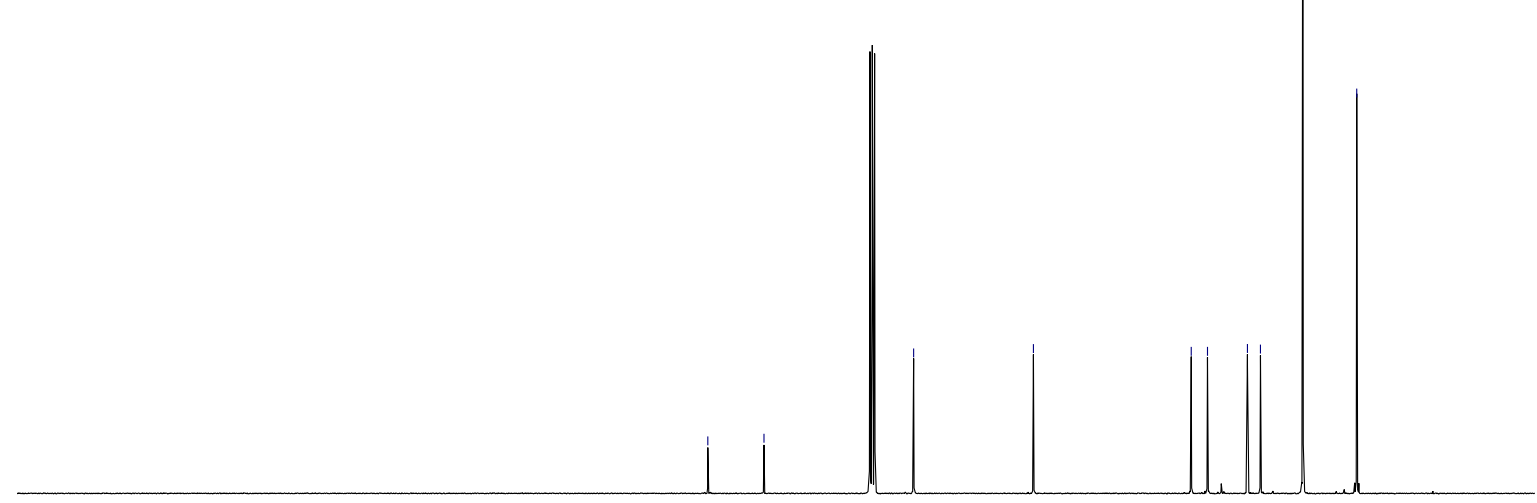

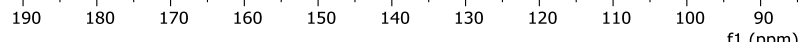


${ }^{1} \mathrm{H}$ NMR (400 MHz, $\mathrm{CDCl}_{3}$ ) of compound $\mathbf{1 3}$ :

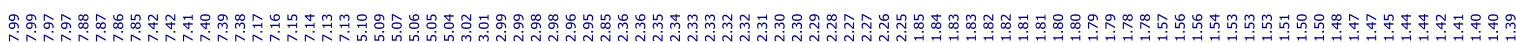<smiles>C#CC1CCCCC1OC(=O)c1ccccc1I</smiles>

13

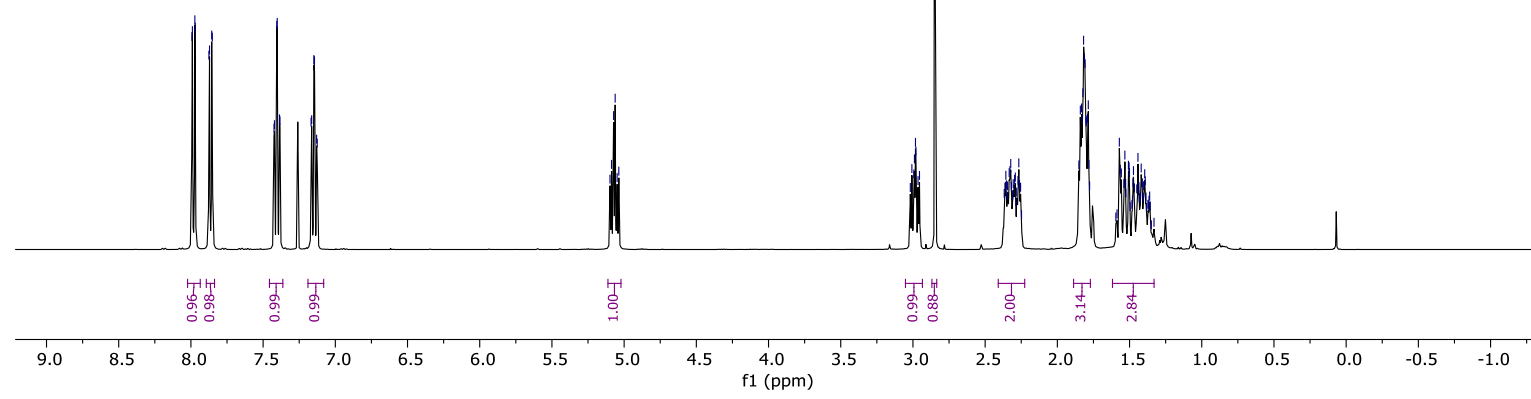

${ }^{13} \mathrm{C}$ NMR (100 MHz, $\left.\mathrm{CDCl}_{3}\right)$ of compound 13:

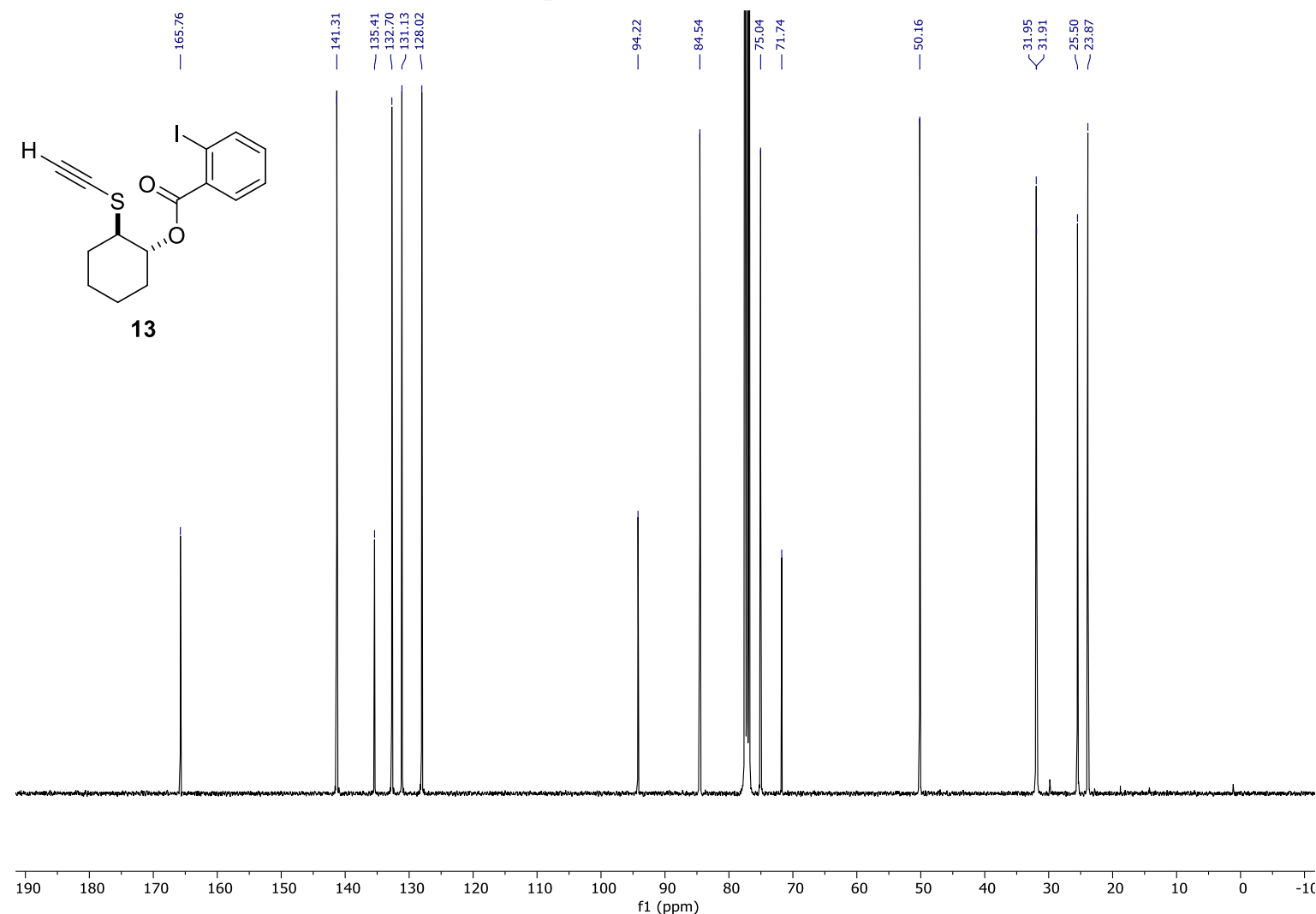


${ }^{1} \mathrm{H}$ NMR (400 MHz, $\mathrm{CDCl}_{3}$ ) of compound 14:

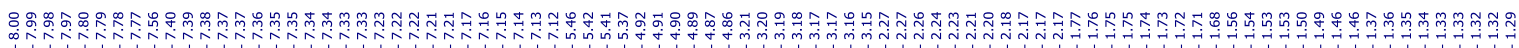

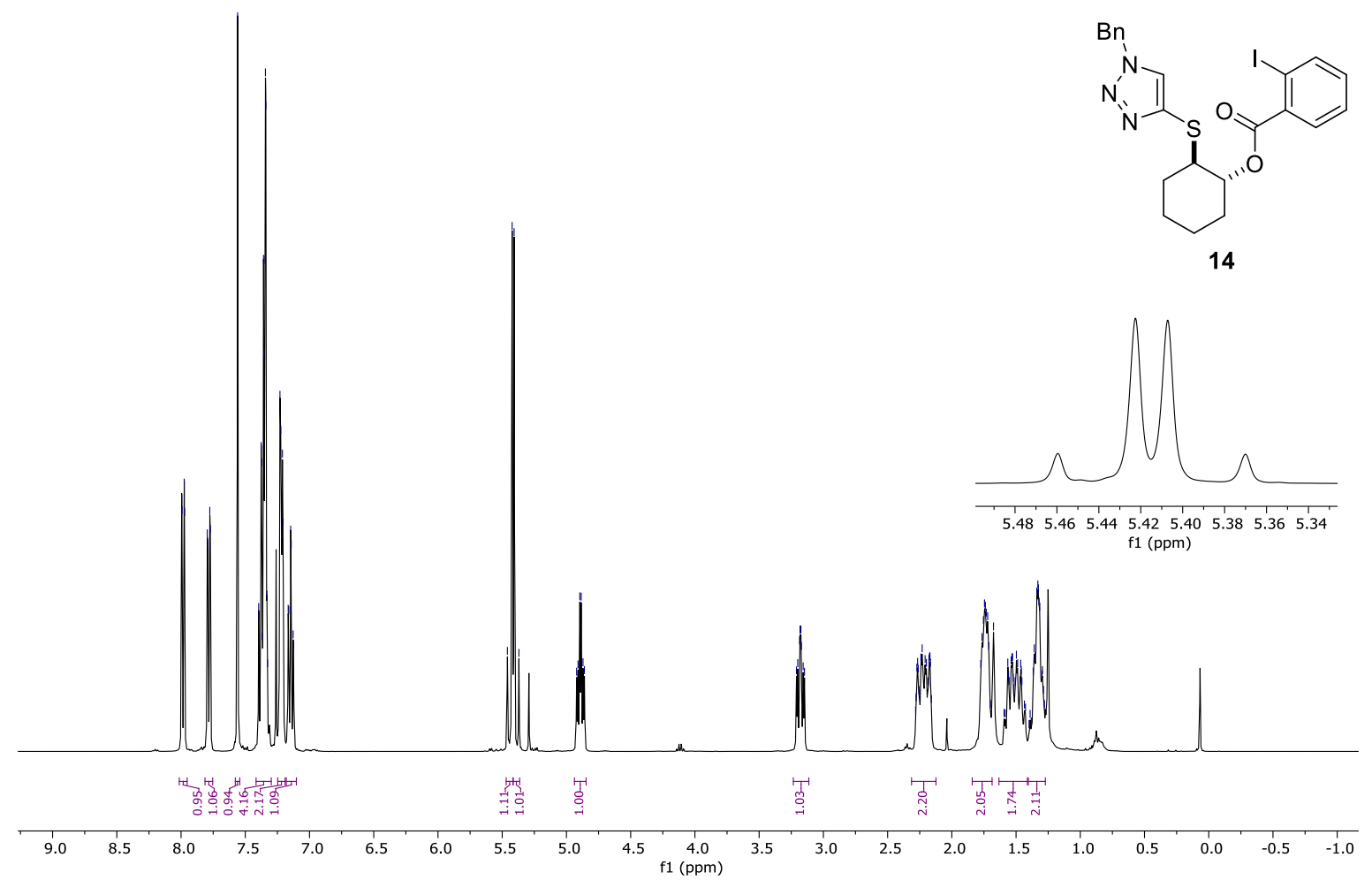

${ }^{13} \mathrm{C}$ NMR (100 MHz, $\left.\mathrm{CDCl}_{3}\right)$ of compound 14:

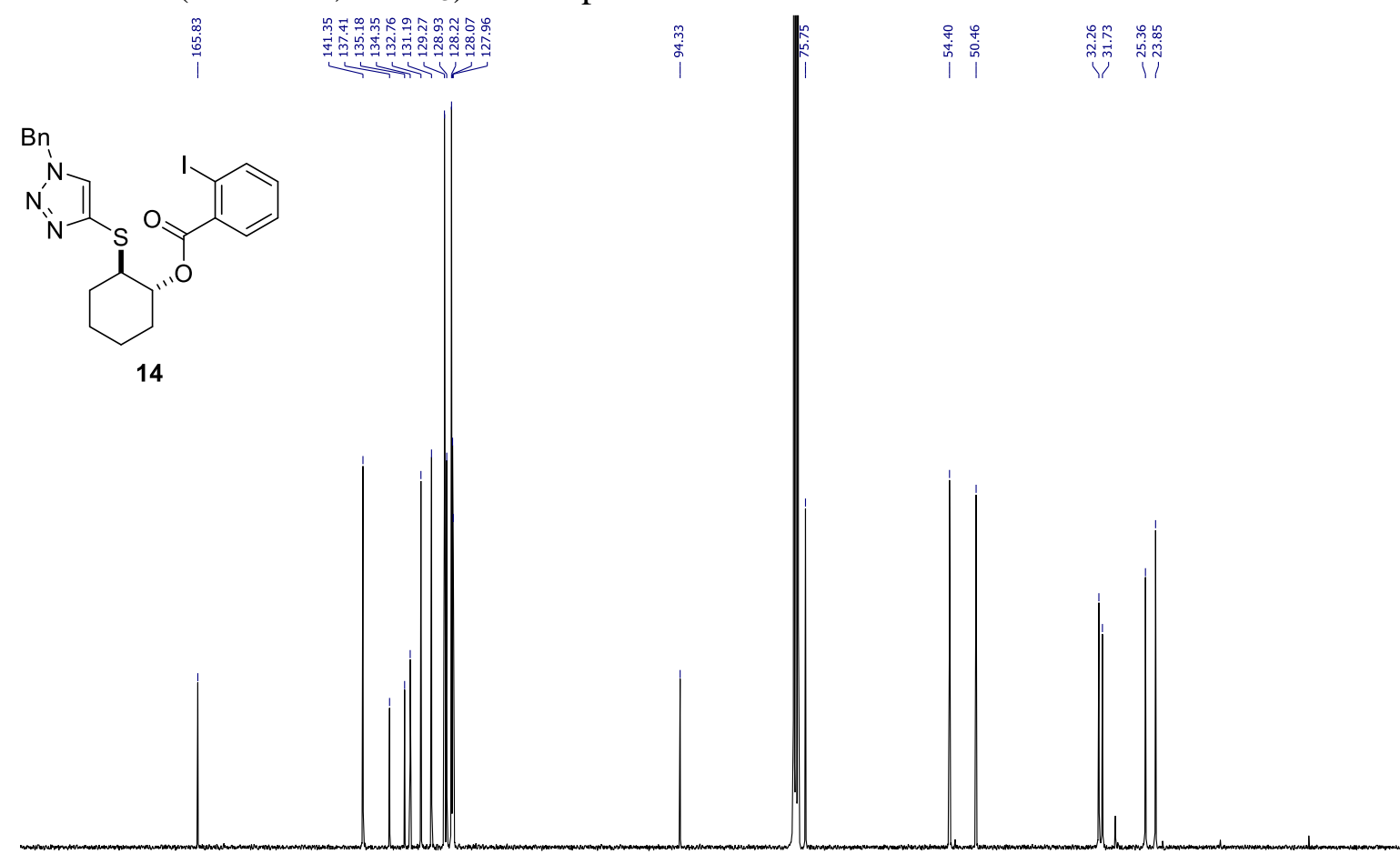

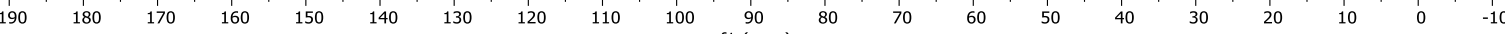


${ }^{1} \mathrm{H}$ NMR (400 MHz, $\mathrm{CDCl}_{3}$ ) of compound 15:

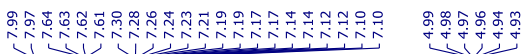

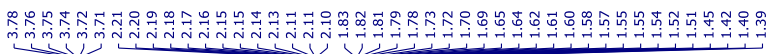<smiles>O=C(Cc1ccccc1)SC1CCCC[C@H]1OC(=O)c1ccccc1I</smiles>

15
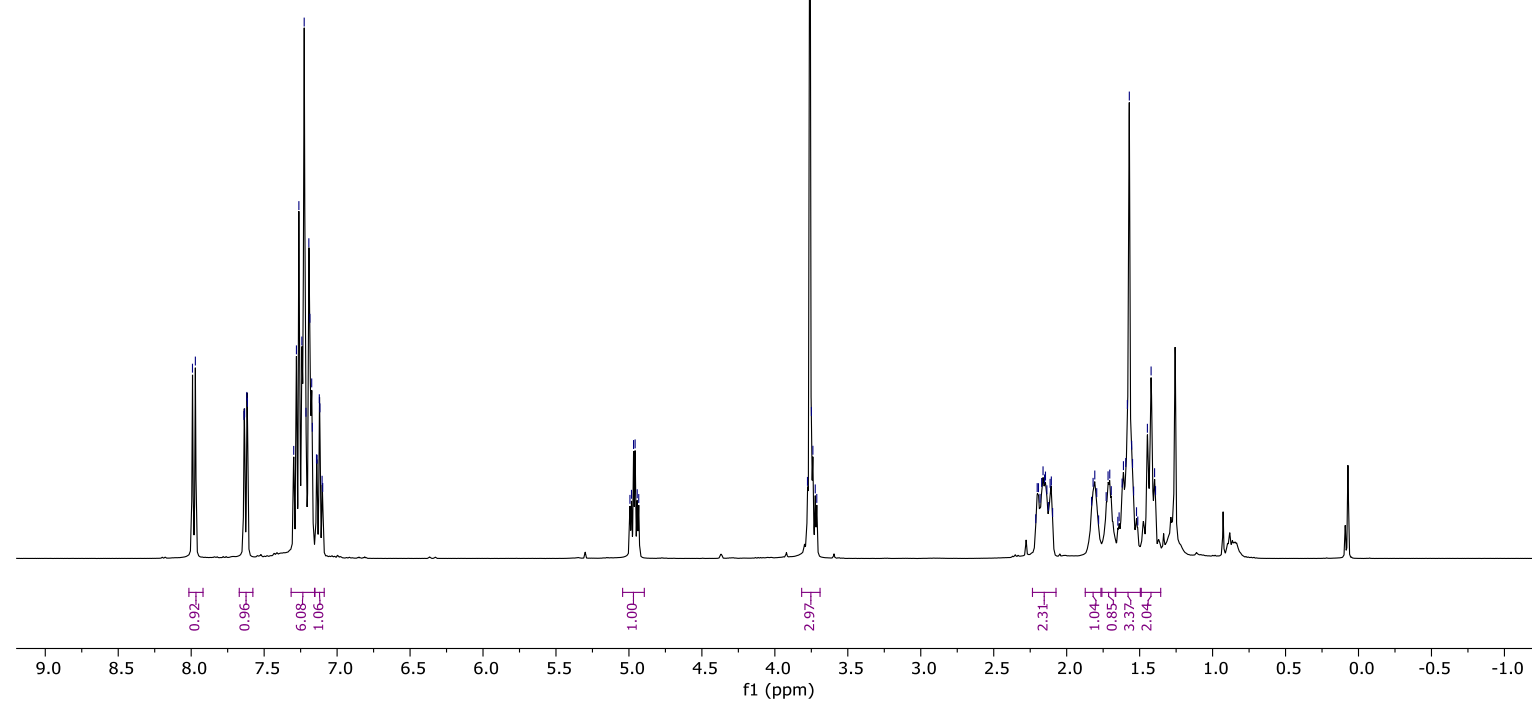

${ }^{13} \mathrm{C}$ NMR (100 MHz, $\left.\mathrm{CDCl}_{3}\right)$ of compound $\mathbf{1 5}$ :

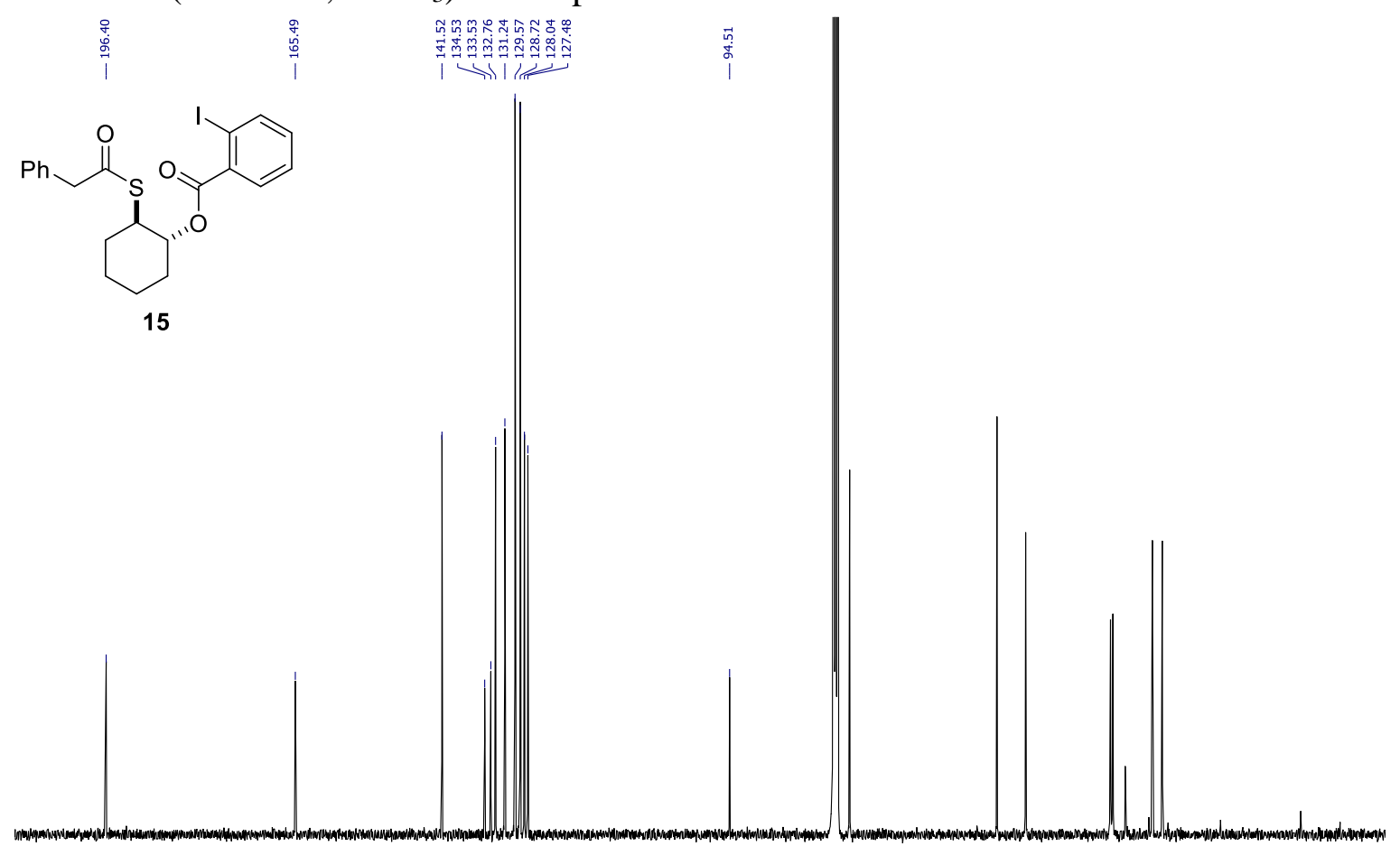

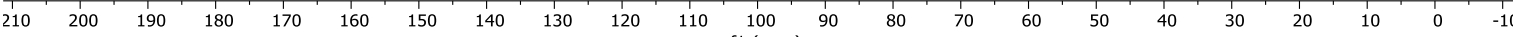


${ }^{1} \mathrm{H}$ NMR (400 MHz, $\mathrm{CDCl}_{3}$ ) of compound $\mathbf{4 3}$ :

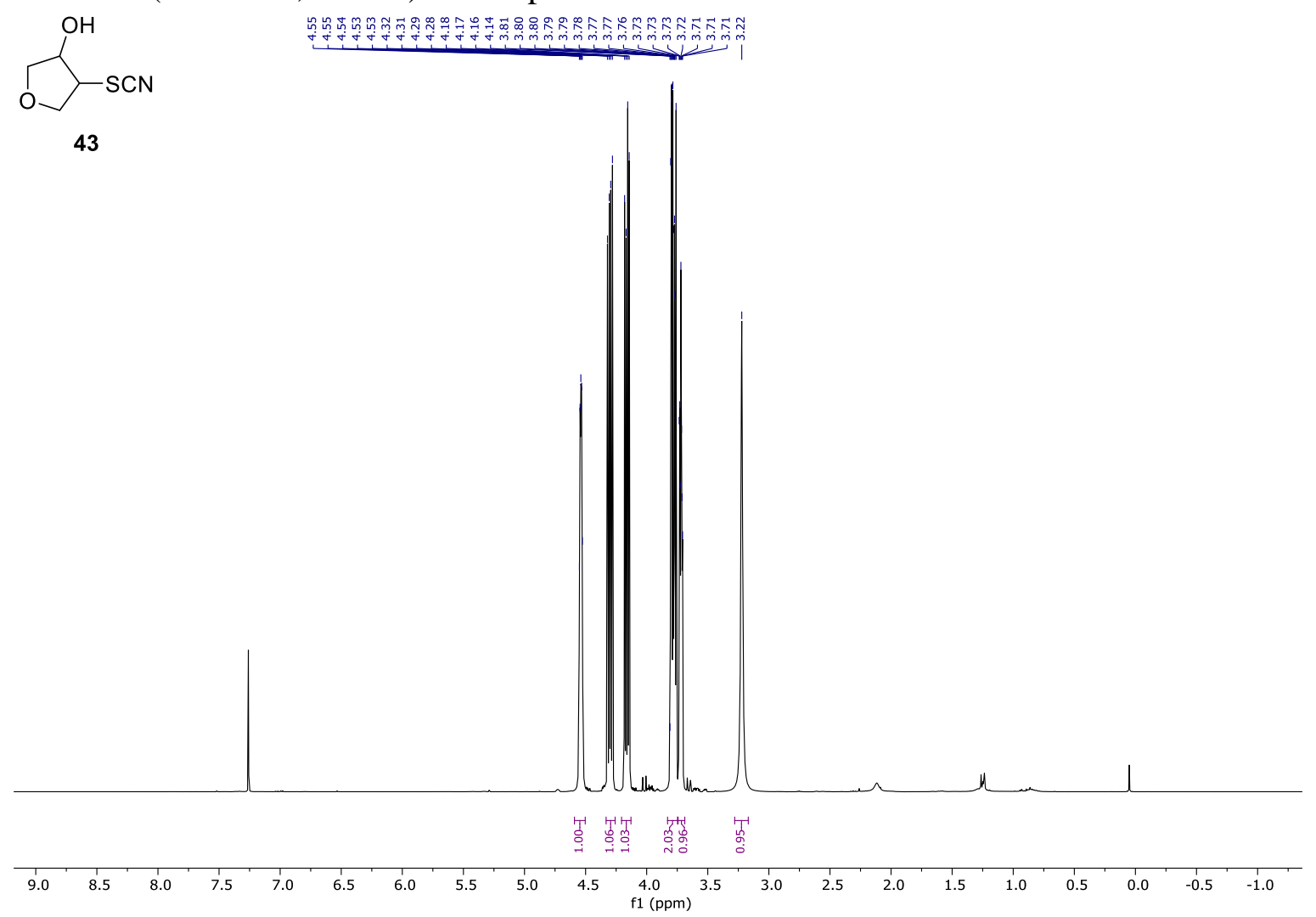

${ }^{13} \mathrm{C}$ NMR (100 MHz, $\mathrm{CDCl}_{3}$ ) of compound 43:<smiles>N#[Sb]C1COCC1O</smiles>

43
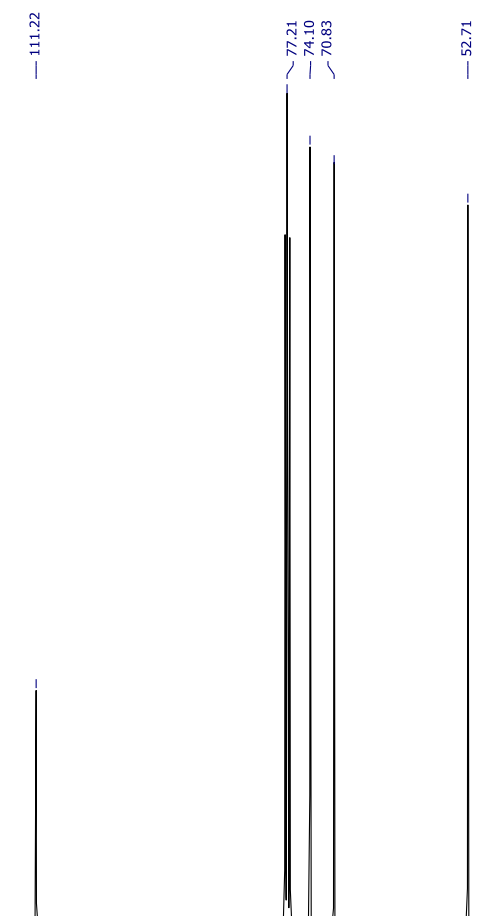
${ }^{1} \mathrm{H}$ NMR (400 MHz, $\mathrm{CDCl}_{3}$ ) of compound 46:

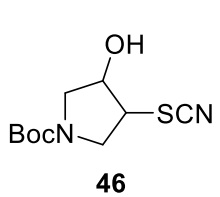

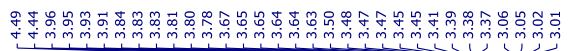

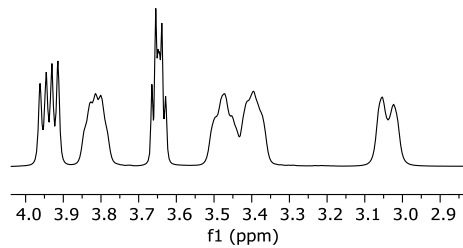

f1 (ppm)

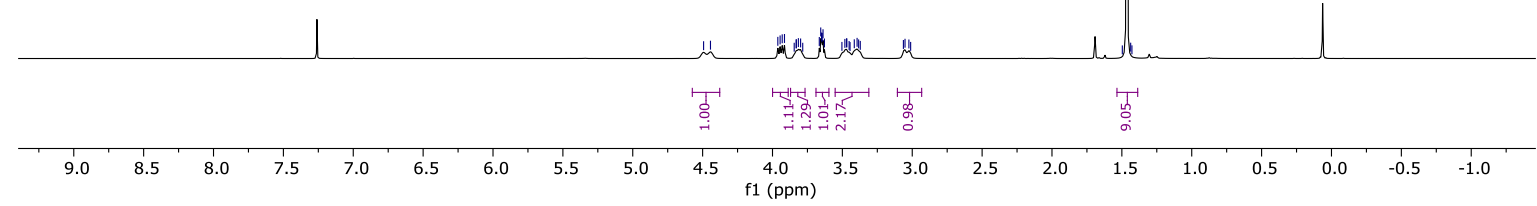

${ }^{13} \mathrm{C}$ NMR (100 MHz, $\left.\mathrm{CDCl}_{3}\right)$ of compound 46:

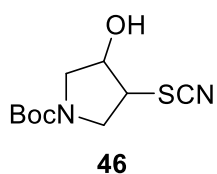

$$
\text { Y }
$$

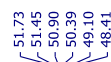

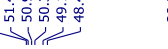

46

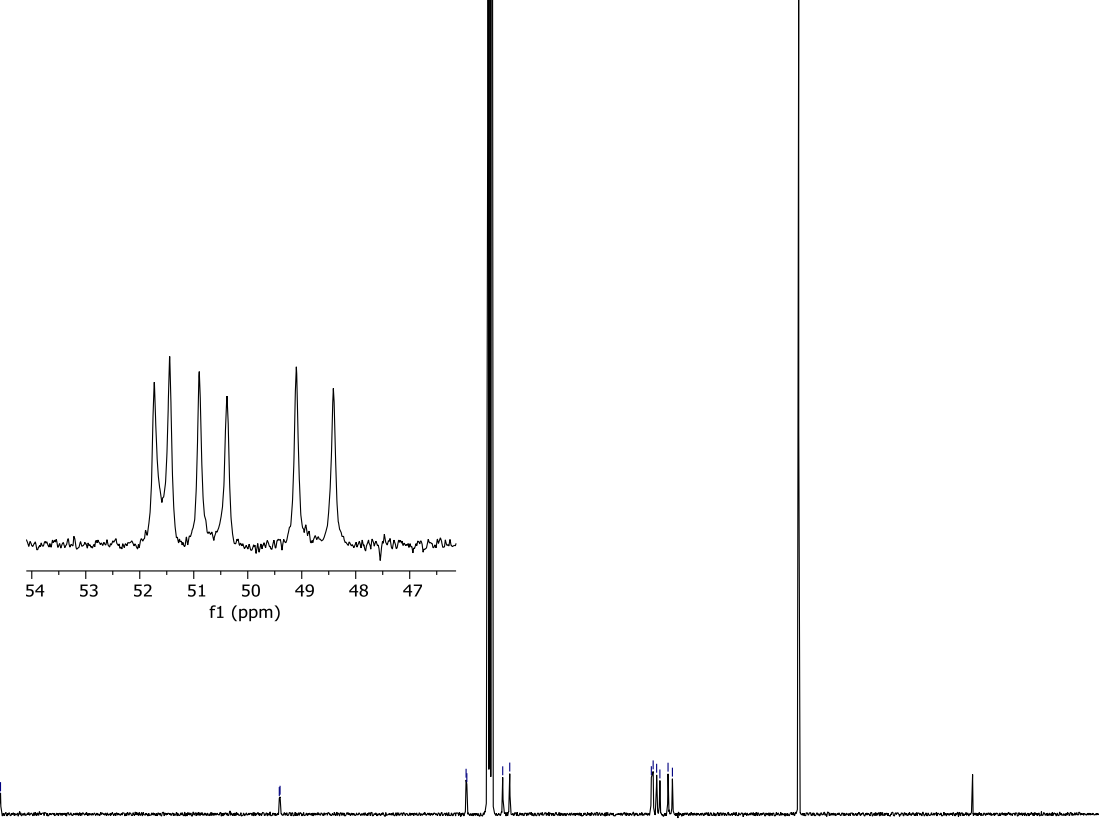

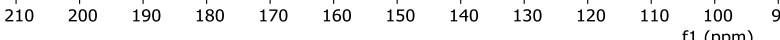

